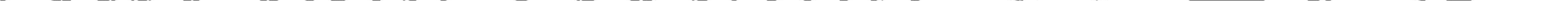





\section{RE-ENVISIONING MODERNITY TRANSFORMATIONS OF POSTWAR SUBURBAN LANDSCAPES}

by

Shannon Clayton

B.Arch.Sci, Ryerson University, 2012

A thesis project

presented to Ryerson University

in partial fulfillment of the

requirements for the degree of

Master of Architecture

Program

(C) Shannon Clayton 2016 



\section{AUTHORS DECLARATION}

I hereby declare that I am the sole author of this thesis. This is a true copy of the thesis, including any required final revisions, as accepted by my examiners.

I authorize Ryerson University to lend this thesis to other institutions or individuals for the purpose of scholarly research.

I further authorize Ryerson University to reproduce this thesis by photocopying or by other means, in total or in part, at the request of other institutions or individuals for the purpose of scholarly research.

I understand that my thesis may be made electronically available to the public.

Shannon Clayton 



\section{ABSTRACT}

While most historic cities show traces of modernist influences, the highest manifestation of modernist planning is found in North America's postwar suburbs. As such, these environments have been highly criticized for their lack of identifiability and public space, characteristics that do not support contemporary human desires for variety and social interaction. In the immediate future, growing demands for housing and transit will create opportunities for urban transformation, and provide a platform for a contemporary critique of modernism and its evolution. This thesis postulates that postwar suburbs can be adapted to better meet the desires of 21 st century residents, while maintaining privacy and access to nature. Through an analysis of potential nodes within existing suburban settlement patterns, and a critical engagement with the ongoing critique of modernism, an architecture which defines public space and creates recognizable images can be developed within the existing fabric of suburbia. 



\section{ACKNOWLEDGEMENTS}

Many thanks to my thesis advisor George Kapelos and second reader Marco Polo for their invaluable contributions to this project. Your collective knowledge and unwavering pursuit of research continues to inspire me.

Thank you to the Ryerson University's Department of Architectural Science for their support and guidance through both my undergraduate and masters degrees.

Finally, thank you to my fiancé Ben, and my parents Rick and Lynn for their continued support over the course of my education. I am eternally grateful to you for enabling me to do what I love. 


\section{LIST OF FIGURES}

\section{INTRODUCTION}

Figure 1: Change in desirable lifestyles between the postwar years and today.

Figure 2: Location of Mississauga in the Greater

Toronto Area.

Figure 3: The emerging Mississauga City Centre [as seen from Burnhamthorpe Rd at Dixie Rd]

Figure 4:Location of selected focus area in Mississauga, Ontario.

\section{CHAPTER 1.1}

Figure 1: Ebenezer Howard's diagrams from The Garden Cities of To-Morrow (1898)

Figure 2: Clarence Perry's "Neighbourhood Unit Diagram" (1929)

Figure 3: Clarence Stein's Plan for Radburn, NJ (1928)

Figure 4: Plan of a cul-de-sac in Radburn, NJ

\section{CHAPTER 1.2}

Figure 1: A photograph from a Levitt and Sons brochure for Levittown

Figure 2: New residents move into their Levitt homes in Levittown, N.Y. (October 1947)

Figure 3: System of parks and schools in the Rathwood/Applewood neighbourhood in Mississauga 19

Figure 4: Sketches by Willo von Moltke, in Joseph

Hudnut, "The Art of Housing," Architectural Record 93 (January 1943): 63

Figure 5: Aerial Photo of Southdale Shopping Center in 1956

Figure 6: Victor Gruen's "Schematic Drawing of the Cellular Metropolis of Tomorrow" from The Heart of Our Cities: The Urban Crisis: Diagnosis and Cure (1964)

Figure 7: Commercial Plazas in the Rathwood/ Applewood neighbourhood in Mississauga Figure 8: Potential 'urban nodes' within the

Rathwood/Applewood neighbourhood in Mississauga 25

\section{CHAPTER 2.1}

Figure 1: Urban critic Lewis Mumford Figure 2: Urban critic Jane Jacobs

Figure 3: Le Corbusier's Sketch for "The Radiant City" 3 (1924)

Figure 4: Cartoon Satire of Suburbia in the New

4 Yorker Magazine 1958, Drawn by Claude Smith

\section{$5 \quad$ CHAPTER 2.2}

6 Figure 1: Kevin Lynch's five points of "Imageability" from The Image of the City (1960)

Figure 2: Sketches of the "duck" and "decorated shed" concepts from Learning From Las Vegas (1972) Figure 3: Venturi Scott Brown's ISI building in

11 Philadelphia (now Drexel's URBN)

Figure 4: Barbara Stauffacher Solomon's interior supergraphics at the Sea Ranch Swim Club.

Figure 5: Images of "Outside the Big Box" by Roger Sherman Architecture \& Urban Design

Figure 6: Robin Hood Gardens, by Peter and Alison Smithson, London, England

Figure 7: Saynatsalo Town Hall, by Alvar Aalto, at

Saynatsalo, Finland, 1949 competition, built 1952.

16 Figure 8: Exeter Library, by Louis I. Kahn, at Exeter, New Hampshire, USA,1967 to 1972.

17 Figure 9: Palace of Assembly, by Le Corbusier, at Chandigarh, India, completed in 1963

Figure 10: "The Plug-In City" by Archigram,1964

Figure 11: Competition Drawing for Centre

Pompidou, by Richard Rogers and Renzo Piano, 1977

20 Figure 12: Modernist residential tower on Dixie Rd.

(as seen from the Rockwood Mall parking lot)

\section{CHAPTER 3.3}

Figure 1: Cover of CIAM's The Heart of the City : 23 Towards the Humanisation of Urban Life (1952). Figure 2: Viljo Revell's winning entry to the 1958 24 Toronto City Hall and Square competition. Figure 3: Conceptual Section drawing for Paul Rudolph's 1970 (unbuilt) Lower Manhattan

Expressway project; one of the most radical proposals during the megastucture's heydey.

Figure 4 \& 5: Amsterdam Orphanage, by Aldo Van

Eyck, 1960

50

Figure 6: Figure 6: Diagram of "Cluster City" concept.

29 (1952-53) Alison and Peter Smithson

Figure 7 (above): Axonometric view of earlier proposal

30 Figures 8 and 9: Photos of earlier design model

\section{CHAPTER 3.1}

Figure 1: Several of the Pruitt-Igoe towers being demolished in April 1972, St. Louis, Missouri.

Figure 2: Sketch by Leon Krier which satirizes the lack

34 of hierarchy in modernist environments

Figure 3: Updated Plan of Seaside, Florida by Andrés

Duany and Elizabeth Plater-Zyberg

Figure 4: Town Square in Seaside, Florida

Figure 5: Homes in Seaside, Florida

Figure 6: A Best Buy store in Leaside, Toronto with a

38 faux-heritage design

Figure 7: Images from the City of Vaughan

39 Metropolitan City Center Secondary Plan (2008-2010), 63 by Urban Strategies

40 Figure 8 (right): Prototype from the City of Toronto's

Tall Building Design Guidelines (2007-2008), by Urban

$41 \quad$ Strategies

\section{CHAPTER 3.2}

Figure 1: Frank Lloyd Wright's "Broadarce City"

43 (1958)

44 Figure 2: Yokohama Ferry Terminal, Foreign Office Architects (2002)

Figure 3: 'Flatspace' by Lateral Office

Figure 4: Vancouver Law Courts, Robson Square

45 Arthur Erickson (1980)

Figure 5: Image of "The Hills at Vallco" from Rafael Viñoly + Olin Landscape Architects

\section{$47 \quad$ CHAPTER 3.3}

Figure 1: 'My Mississauga' events in Downtown

\section{Missisauga}

Figure 2: Seniors meeting for coffee at the Rockwood

Mall in Mississauga.

Figure 3: Locations of designated 'community nodes' 49 in the Mississauga Official Plan (updated August 11 2015) 
Figure 4: Image of "New Suburbanism" from LTL Architects

\section{CHAPTER 4.1}

Figure 1: Existing typologies in Rathwood/Applewood 78 Figure 2: Proportion of dwelling types in Rathwood/ Applewood.

Figure 3: Plan of Rathwood/Applewood [Ward 3 of the City of Mississauga]

\section{CHAPTER 4.2}

Figure 1: Identification of the Rathwood/Applewood Community Node Character Area, including the existing Rockwood Mall site.

Figure 2: Existing land uses of the Rathwood/

Applewood Community Node Character Area.

Figure 3: Identification of existing bus routes through

the Rathwood/Applewood Area.

Figure 4: Existing Rockwood Mall Site Plan

Figure 5: Dixie Road [looking north toward Rockwood

Mall]

Figure 6: Dixie Road [looking south]

Figure 7: Rathburn Road [looking east toward

Rockwood Mall]

Figure 8: Inside mall parking lot [looking west toward

Rathburn Road]

Figure 9: Bough Beeches Boulevard [looking south

toward Rockwood Mall]

Figure 10: Bough Beeches Boulevard [Looking north

toward Residential streets]

Figure 11: Burnhamthorpe Road [looking east toward

Rockwood Mall]

Figure 12: Burnhamthorpe Road [Looking west]

Figure 13: Scale of site as relative to Toronto City Hall

and Nathan Phillips Square

Figure 14: Context of Toronto City Hall and Nathan

Phillips Square

Figure 15: Scale of site as relative to a section of the

Regent Park Redevelopment Plan

Figure 16: Context of the Regent Park

Redevelopment Plan

Figure 2: Lijnbann, Rotterdam (March 30, 1967)

75 Figure 3: Rotterdam's "Cube houses" (1977) by Piet Blom

Figures 4: Ypenburg, a Vinex suburb of The Hague,

The Netherlands

Figure 5: Masterplan for Almere Centruum by OMA

(1994-2005)

Figure 6: Construction photo of Almere

79 Centruum

\section{CHAPTER 5.2}

Figure 1: Dutch firm Mecanoo became known for a neo-moderist aesthetic during the 1980s. As seen

81 here in their Kruisplein social housing project in

Rotterdam (1981-1985)

82 Figure 2: De Rotterdam by OMA (2013)

\section{CHAPTER 5.3}

Figure 1: Strategy 1 - Integration of landscape into architecture

85 Figure 2: View towards the entrance to the TU Delft library

85 Figure 3: Strategy 2 - Concept-driven design approach

85 Figure 4: Strategy 3 - Program-driven concept Figure 5: Programmatic organization of Markethal 85 (MVRDV)

Figure 6: Image of Markethal (2015) by MVRDV

85 Figure 7: A pragmatic approach towards the programs of suburbia - providing a platform for landscape and public space, and recognisable form; through a megastructure of mixed programs

Figure 8: Strategy 3 - Use of competition and cross86 collaboration

\section{CHAPTER 5.1}

Figure 1: Sketch by Van den Broek \& Bakema 



\section{TABLE OF CONTENTS}

INTRODUCTION

PART 1: HISTORY AND ANALYSIS OF POSTWAR SUBURBIA

1.1 A Brief History of Prewar Suburbs

1.2 History and Analysis of Postwar Suburbs

10-15

$16-25$

PART 2: POSTWAR CRITIQUES OF MODERNISM \& SUBURBIA

2.1 Critique of Sociology

2.2 Critique of Imageability

2.3 Critique of Urban Space

PART 3: RECENT ATTEMPTS TO TRANSFORM SUBURBIA

3.1 New Urbanism: A Critical Analysis

3.2 Landscape Urbanism: A Redemption of Modernism?

3.3 New Suburban History: An Analysis of Potential

28-32

$34-45$

$46-53$
PART 4: A CASE FOR INTERVENTION EXISTING CONDITIONS OF A TYPICAL POSTWAR SUBURB

4.1 General Characteristics

78-79

4.2 Pre - Intervention Analysis

80-87

PART 5: THE FUTURE OF SUBURBIA

5.1 The Generic City: Learning from the Netherlands

90-95

5.2 The Emergence of Supermodernism

$96-100$

\section{Postwar Suburbs}

PART 6: AN URBAN STRATEGY FOR SUBURBIA ROCKWOOD MALL REDEVELOPMENT PROPOSAL

IMAGE CREDITS 
1 Andrew Blauvelt, "Preface: Worlds Away and the World Next Door" in Worlds Away: New Suburban Landscapes, (Minneapolis: Walker Art Center, 2008), 14

2 Margaret Crawford, "Afterword" in Making Suburbia: New Histories of Everyday America, ed. John Archer, Paul J. P. Sandul, and Katherine Solomonson (Minneapolis: University of Minnesota Press, 2015), 386

3 A 2008 exhibition entitled "Worlds Away: New Suburban Landscapes" was held at the Walker Art Gallery in Minneapolis, Minnesota. In an interview within the accompanying book of essays, co-curator Tracy Myers asserts, "My mantra is that more than half the country lives in suburbs: the suburbs are not going to go away, so rather than demonizing them, maybe there are ways to bring some bette qualities to them through the practice and thinking of architecture."

Katherine Solomonson, "A Conversation with Andrew Blauvelt and Tracy Myers." in Worlds Away: New Suburban Landscapes, ed. Andrew Blauvelt (Minneapolis: Walker Art Center, 2008), 18

4 Robert Venturi and Denise Scott-Brown, Learning from Las Vegas: The Forgotten Symbolism of Architectural Form. Rev. ed. (Cambridge, Mass.: MIT Press, 1977), 3

\section{INTRODUCTION}

\section{"Learning from the existing landscape is a way of being revolutionary for an architect"}

Robert Venturi and Denise Scott Brown (1972)

Until recently, the majority of architects and urban professionals seem to have opted out of discussions on transforming the suburbs, discounting them as the domain of the ignorant; those with less taste and knowledge than themselves. Historically (in both academic and popular culture), suburbia has been used as the scapegoat for the ills of society, such as sexism, consumerism, and environmental decay. ${ }^{2}$ Fortunately, this pessimism is quickly diminishing. In recent years, designers and urban professionals are growing increasingly engaged in a discussion on how to make suburbs more sustainable and livable places. ${ }^{3}$ In the spirit of Robert Venturi and Denise Scott-Brown's notion that, "learning from the existing landscape is a way of being revolutionary for an architect", 4 designers and urbanists are investigating the potential of suburban landscapes.
Although this change in attitude is promising, suburban environments present many challenges. Mass suburbanization came of age after World War II, as a response to growing housing demands. These developments followed principles of modernism - with an emphasis on the automobile, and use of mass-production. These characteristics have resulted in a lack of identifiability and human-scaled public space - issues which are synonymous with familiar critiques of orthodox modernism.

From a contemporary perspective, these issues have only become more problematic. The world is increasingly globalized and digital. More than ever, individuals have increased access, information, and mobility. This translates into greater choice, customization and variety. Increasingly, individuals are seeking 


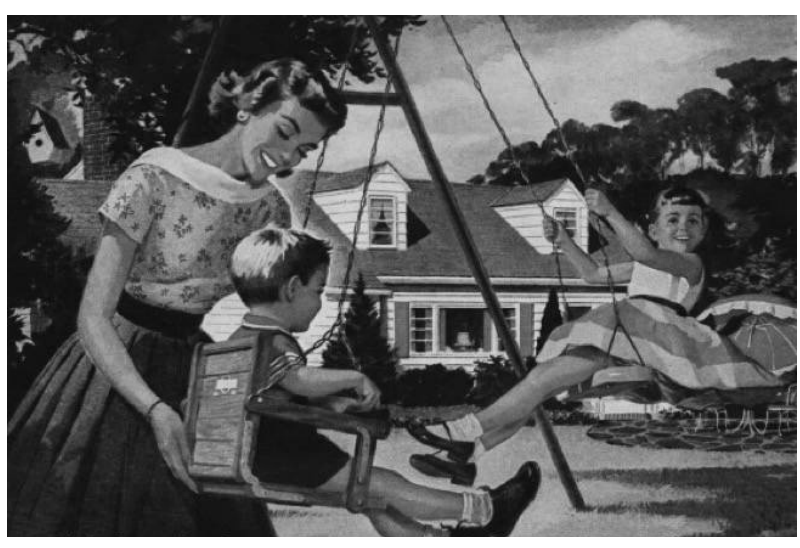

POSTWAR AGE:

COMFORT, SECURITY, STABILITY

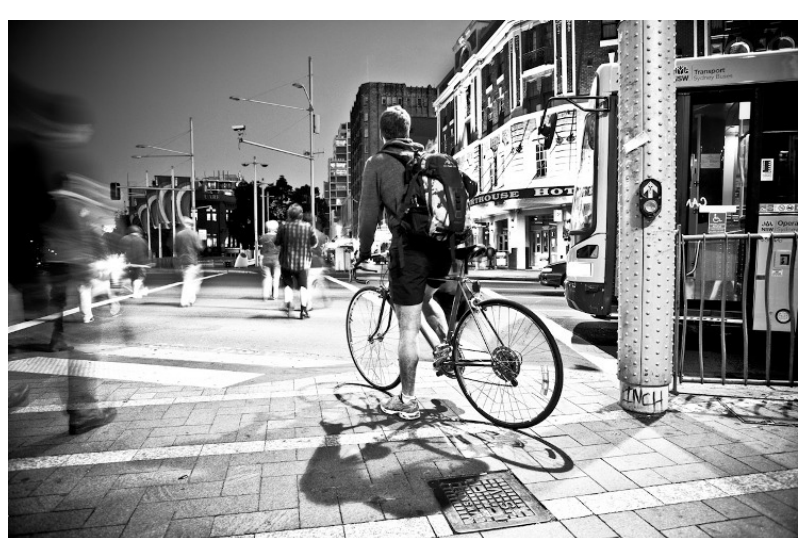

CONTEMPORARY AGE:

VARIETY, STIMULATION, INTERCONNECTION

Figure 1: Change in desirable lifestyles between the postwar years and today.

lifestyles which support greater variety and interconnection. Thus, the contemporary perspective is drastically different from the desire for comfort and stability which characterized the postwar age.

(Figure 1)

Recent trends show that growing numbers of individuals and families are seeking more urban lifestyles. In The End of The Suburbs: Where the American Dream Is Moving (2013), Leigh Gallagher cites primary reasons for this trend as: increased investment and more stable real estate values in cities, the declining birth rate and delay or avoidance of marriage, an indifferent or resistant attitude towards driving, and a desire for stimulating social activity. This is coupled with the impact of commuting on the health of both individuals and the environment. Gallagher suggests that this is less of a city versus suburb debate but rather a question of suburbia's ability to develop more urban qualities. ${ }^{5}$ As such, there is a general consensus among urban professionals that in order to remain desirable places to live, suburban places must evolve to become more walkable, transit oriented, and culturally engaging.

\section{In Sprawltown: Looking for the} City on Its Edges (2006), Richard Ingersoll suggests that: "In the end, sprawl is already a mature form of urbanism, one that by now is in desperate need of restoration." 6 Just as historic cities and buildings have been continually updated to suit the desires of
5 Leigh Gallagher, The End of the Suburbs: Where the American Dream Is Moving ( New York: Penguin Group, 2013), 159

6 Richard Ingersoll, Sprawltown: Looking for the City on Its Edges (New York: Princeton Architectural Press, 2006), 7 
7 Tom Urbaniak, Her Worship: Hazel McCallion and the Development of Mississauga (Toronto: University of Toronto Press, 2009), 10

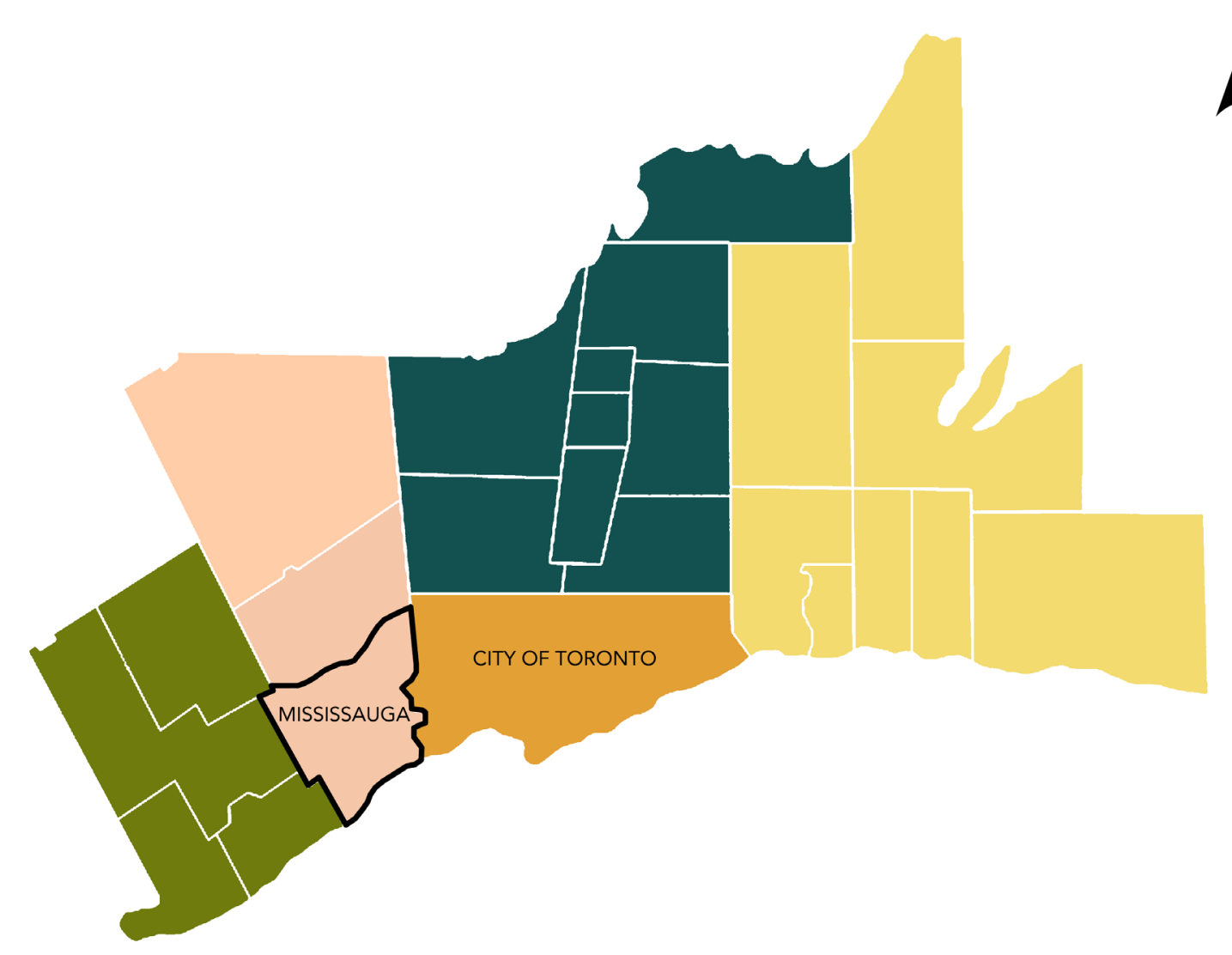

Figure 2: Location of Mississauga in the Greater Toronto Area.

$21^{\text {st }}$ century residents, so too should North America's postwar suburbs.

\section{As populations in urban areas} continue to grow, suburban regions are becoming cities in their own right. One such example is the City of Mississauga, a suburban community west of the City of Toronto. Beginning in the 1950s, subdivision development gradually engulfed its small historic villages. At present, Mississauga can no longer expand via traditional greenfield development, yet its population continues to increase. Thus, the city is now forced to densify from within. ${ }^{7}$ In Her Worship: Hazel McCallion and the Development of Mississauga (2009), Tom Urbaniak suggests that the current 


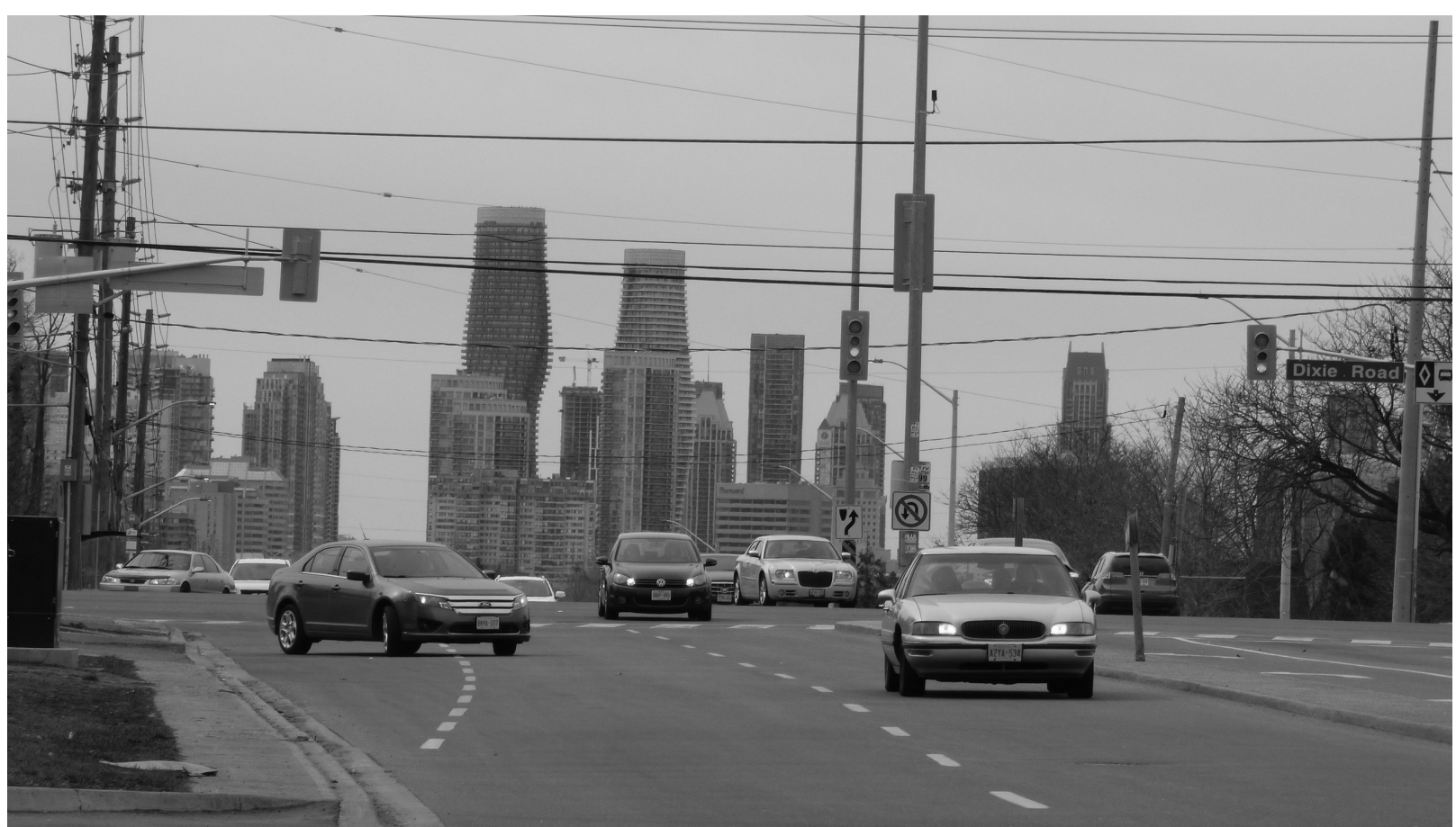

Figure 3: The emerging Mississauga City Centre [as seen from Burnhamthorpe Rd at Dixie Rd]

municipal government is much less resistant to this inevitability than previous regimes. Recent strategic planning and branding exercises have expressed Mississauga's desire to be recognized as a city in its own right, with a separate identity from Toronto. Mississauga's current Official Plan seeks to encourage denser 'community nodes' within existing neighbourhoods, and further develop a 'downtown' city centre surrounding the Square One Shopping Mall and Mississauga City Hall. (Figure 3) The city has also made significant investments in transit infrastructure in order to support this development. Mississauga's Strategic Plan (2014) shows an intention to foster neighbourhood identities without compromising the natural features, and 'neighbourhood feel' that residents continue to value. Through this process, Mississauga also hopes to create more jobs and support incoming immigrants. It would seem that the most exciting thing about Mississauga is its future, not its past. Thus, Mississauga (and other suburban regions) would be wise to embrace their youth as a method to foster a stronger identity. 


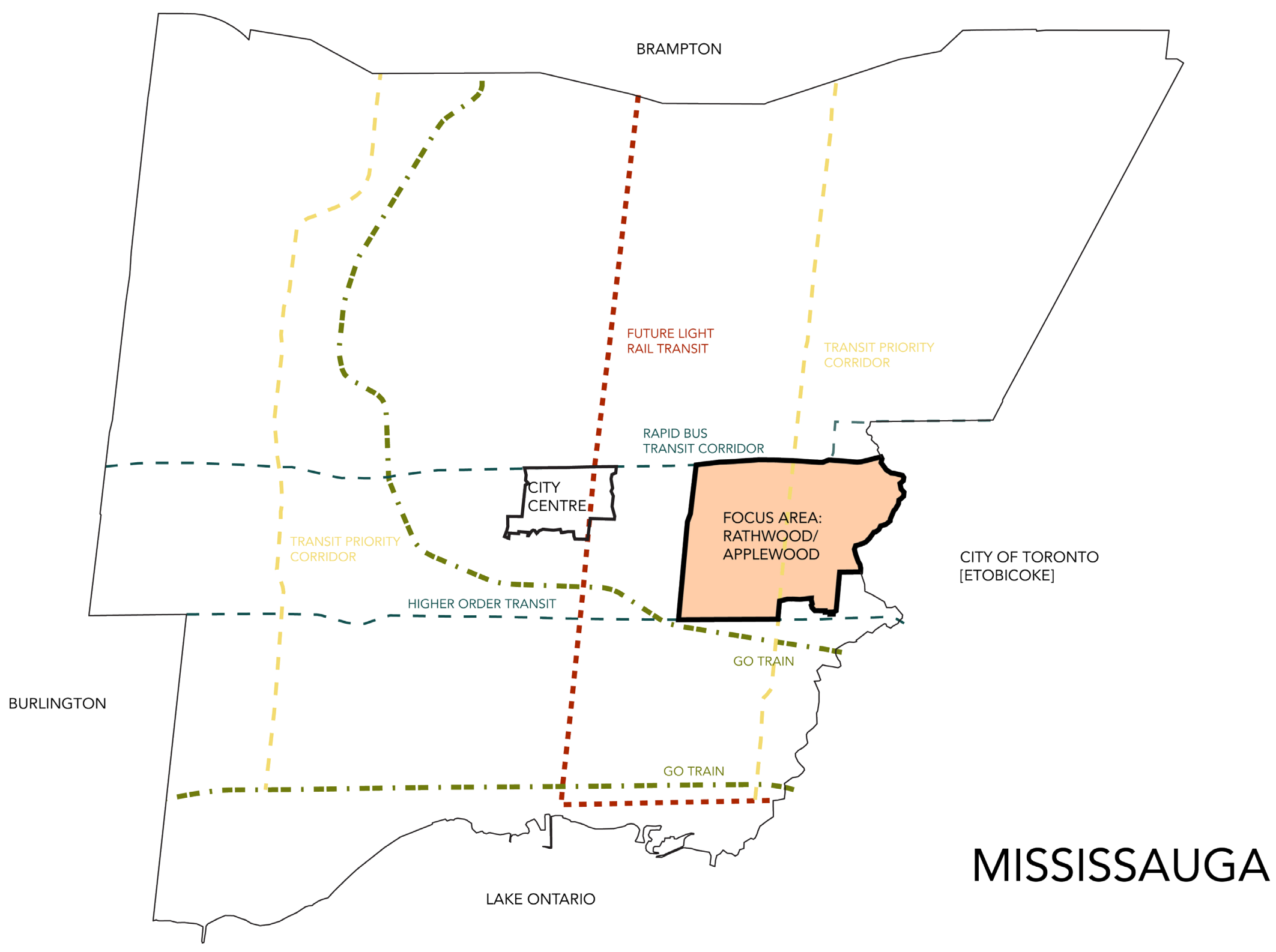

$\Delta$

Figure 4: Location of selected focus area in Mississauga, Ontario. 


\section{"Make no little plans; they have no magic to stir men's blood"}

Daniel Burnham (1907)

Although the modernist structure of postwar suburbs presents many challenges, it also presents unique opportunities for design intervention. Modernism embodied an optimism towards creating new urban conditions. In the early 20th century, the architect and planner Daniel Burnham embodied this utopian attitude with the phrase, "make no little plans; they have no magic to stir men's blood." " This thesis aims to reexamine this position from a contemporary perspective. Through critical analysis and design intervention, suburbia could become notable for its modernity, rather than deemed inferior to historic places.

This thesis postulates that postwar suburbs can be adapted to better meet the desires of 21 st century residents, while maintaining privacy and access to nature. Through analysis of potential nodes within existing suburban settlement patterns, and a critical engagement with the ongoing critique of modernism, an architecture which defines public space and creates recognizable images can be developed within the existing fabric.

The thesis project will explore the redevelopment of an existing shopping centre site in the Rathwood/Applewood neighbourhood in Mississauga. The area was chosen due to its close proximity to the City of Toronto and the emerging Mississauga City Centre, and its characteristics which are typical of postwar suburban planning. Due to its location, this area will likely experience developmental growth in the near future. The project will explore how the demand for increased density can be utilized as an opportunity to insert public space and identifiable images into an existing modernist environment. The project will suggest a prototypical urban strategy which could be adapted to other potential nodes within existing suburban networks. 


\section{PART 1: HISTORY AND ANALYSIS OF POSTWAR SUBURBIA}


1 Robert Bruegmann, Sprawl: A Compact History (Chicago: University of Chicago Press, 2005), 9

2 Oliver Gillham, " "What Is Sprawl" from The Limitless City: A primer on the Urban Sprawl Debate." 2002. In The Urban Design Reader, ed. Michael Larice and Elizabeth Macdonald (London: Routledge, 2007), 304

3 Robert Bruegmann, Sprawl: A Compact History (Chicago: University of Chicago Press, 2005), 23

4 Becky M. Nicolaides and Andrew Wiese, "Chapter 1 The Transnational Origins of the Elite Suburb (Introduction)", in The Suburb Reader (New York: Routledge, 2006), 13

5 Andrew Blauvelt, "Preface: Worlds Away and the World Next Door" in Worlds Away: New Suburban Landscapes, (Minneapolis: Walker Art Center, 2008), 10

\section{CHAPTER 1.1 A BRIEF HISTORY OF PREWAR SUBURBS}

While the words suburb and sprawl are often considered interchangeable, they are distinct concepts. The process of expansion which many call "urban sprawl" has been a constant activity of urban development. In Sprawl: A Compact History (2005), Robert Breugmann asserts that "sprawl is neither a recent phenomenon nor peculiarly American. " ${ }^{1}$ Generally, as populations have risen in urban areas all over the world, cities have expanded to accommodate this. Although there is not one consensus on its meaning, within the latter part of the $20^{\text {th }}$ century to present times, the word 'sprawl' has been associated with postwar suburban development, loosely defined as "a form of urbanization distinguished by leapfrog patterns, commercial strips, low density, separated land uses, automobile dominance, and a minimum of public open space." 2 Because of this confusion, 'sprawl' is a fairly useless and misused word. However, suburb has a very specific meaning and intention.

The word suburb finds its etymological root in the suburbium of
Ancient Rome. The latin suburbium translates into "what was literally below or outside the walls." 3 The "sub" in suburb is the same root found in the words subordinate, substandard, subpar etc.; thus it implies that it is somehow 'less than'. Until the $18^{\text {th }}$ century, a suburb was a zone for undesirable activities and land-uses and the dwellings of marginalized populations. ${ }^{4}$ As many sources have reported, it is only in the last two hundred years that suburbs came to be valued as desirable places to live. The earliest of these suburbs were created to escape the unpleasant realities of industrial cities, and better engage with nature (inspired by $18^{\text {th }}$ century Romanticism). ${ }^{5}$ These ideas found their genesis in the publication of Ebenezer Howard's The Garden Cities of To-Morrow in Britain in 1898. Responding to the overcrowding and unhealthy living conditions of industrial cities [ie. London], Howard advocated for the creation of satellite towns which would be connected to the city by rail. The Garden City was intended to be a combination of the best of both rural and urban life; a socalled "town-country magnet" (Figure 5)

Howard's idea for the Garden City is often considered the first instance of modern town planning, due to its planned 

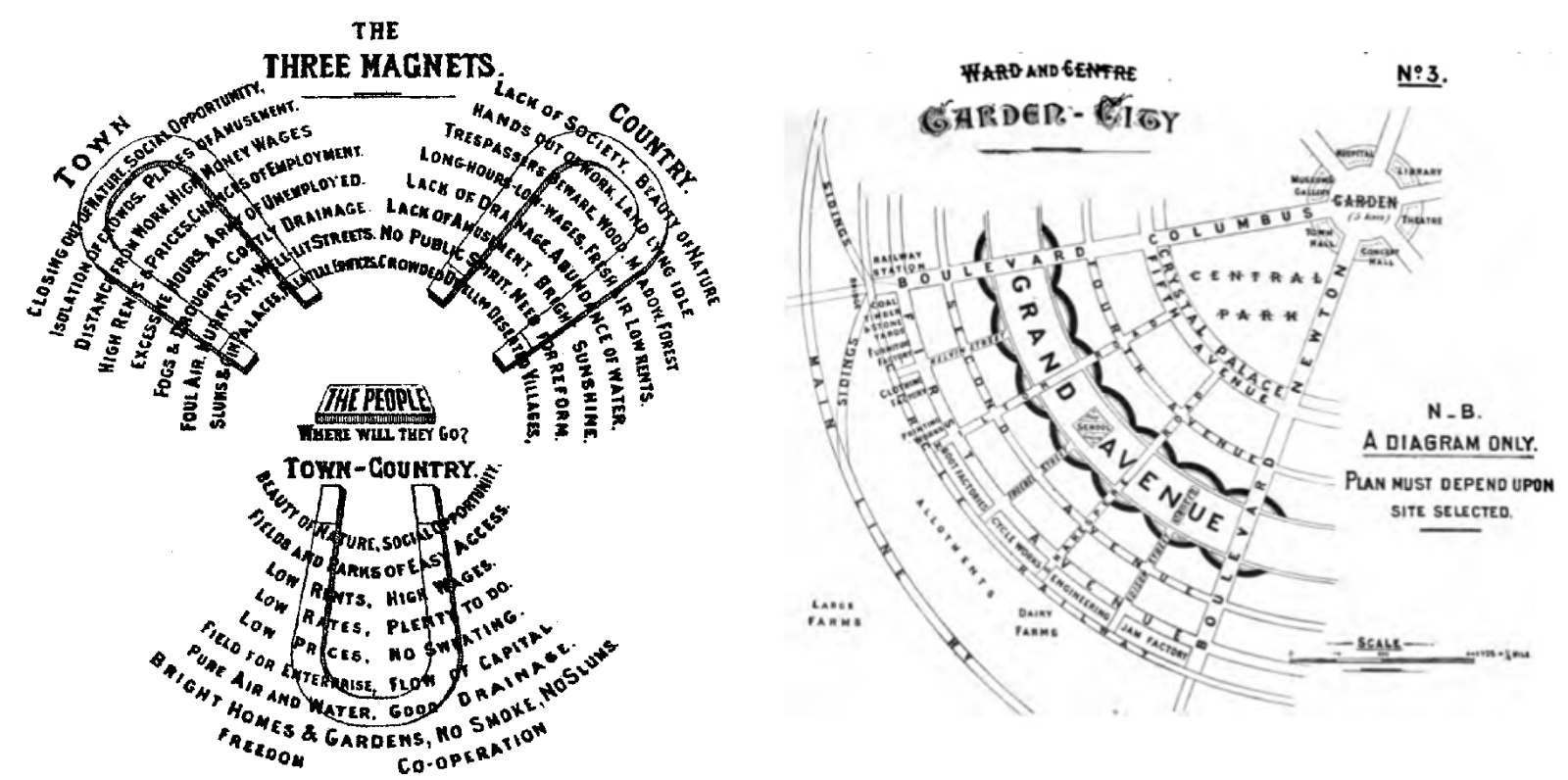

Figure 1: Ebenezer Howard's diagrams from The Garden Cities of To-Morrow (1898)

separation of civic, residential, industrial, and agriculture uses. This approach was the foundation of later ideas of zoning, decentralization, and the value of nature in urban environments. ${ }^{6}$ Although Howard only succeeded in creating two Garden Cities in the UK (Letchworth and Welwyn) with the help of Barry Parker and Raymond Unwin ${ }^{7}$, it was an extremely influential model for early suburbs in Europe and North America.

Other than its application to company towns designed to house workers, Garden City-like communities were
6 Lewis Mumford, " "The Garden City Idea and Modern Planning" From the 1946 Introduction to Garden Cities of To-Morrow (1902)." in The Urban Design Reader, ed. Michael Larice and Elizabeth Macdonald (London: Routledge, 2007), 44

\section{7 lbid}

8 Robert Fishman, Bourgeois Utopias: The Rise and Fall of Suburbia (New York: Basic Books, 1987), 9

9 Ibid, $x$ 
10 John Archer, Architecture and Suburbia: From English Villa to American Dream House, 1690--2000 (Minneapolis: University of Minnesota Press, 2005), Xvi

11 Richard Harris, Creeping Conformity: How Canada Became Suburban, 1900-1960 (Toronto: University of Toronto Press, 2004), 33

12 Clarence Perry, " "The Neighbourhood Unit" from The Regional Plan of New York and Its Environs."

1929. In The Urban Design Reader, ed. Michael Larice and Elizabeth Macdonald (London: Routledge, 2007), 54

13 lbid, 55

14 lbid, 54 liberty and the pursuit of happiness' that go back to the $18^{\text {th }}$ century Enlightenment and the Declaration of Independence. Since then, private property has been seen as a measure of self-fulfillment and freedom; integral to the concept of the 'American Dream.' ${ }^{10}$ Though not quite as literal, Canadian values are consistent with this ideology. In Creeping Conformity: How Canada Became Suburban, 1900-1960 (2004), Richard Harris explains:

"Suburbs, then, have been promoted and settled for a variety of reasons that, collectively, express a good deal about Canadian society: a belief in the primacy of laissez-faire development, individualism, the right to property, and the virtue of private domesticity."

\section{After Howard, the next highly} influential model on suburban development was "The Neighbourhood Unit" by Clarence Perry, first published in the Regional Plan of New York and its Environs in 1929. By the 1920s, many Garden Cityinspired suburbs had been built throughout Europe and North America, as central cities were continually associated with congestion, crime, and poverty. It was at this time when Clarence Perry attempted to develop a specifically American approach to the concept, which would better consider the growing reliance on automobiles. While Unwin and Parker had imagined the Garden City as a single entity, Perry organized his suburb as a series of self-contained "neighbourhood units." 12 Perry explains,

"The underlying principle of the scheme is that an urban neighbourhood should be regarded both as a unit of a larger whole and as a distinct entity in itself."13

Each unit would be centered on an elementary school (sometimes with a church and/or a community centre), which would serve the appropriate population. (Figure 2) Each unit would be surrounded by arterial roads where shops and apartment buildings would be located. Access within the neighbourhood would be facilitated by narrow curvilinear streets which would discourage high speeds. There was great emphasis placed on an abundance of parks and playgrounds which were to be connected by pedestrian paths. ${ }^{14}$ The importance that this plan places on the school, parks, and the discouragement of through traffic, suggests that the primary intention of the suburb (at this time) was to create a safe environment for children. 


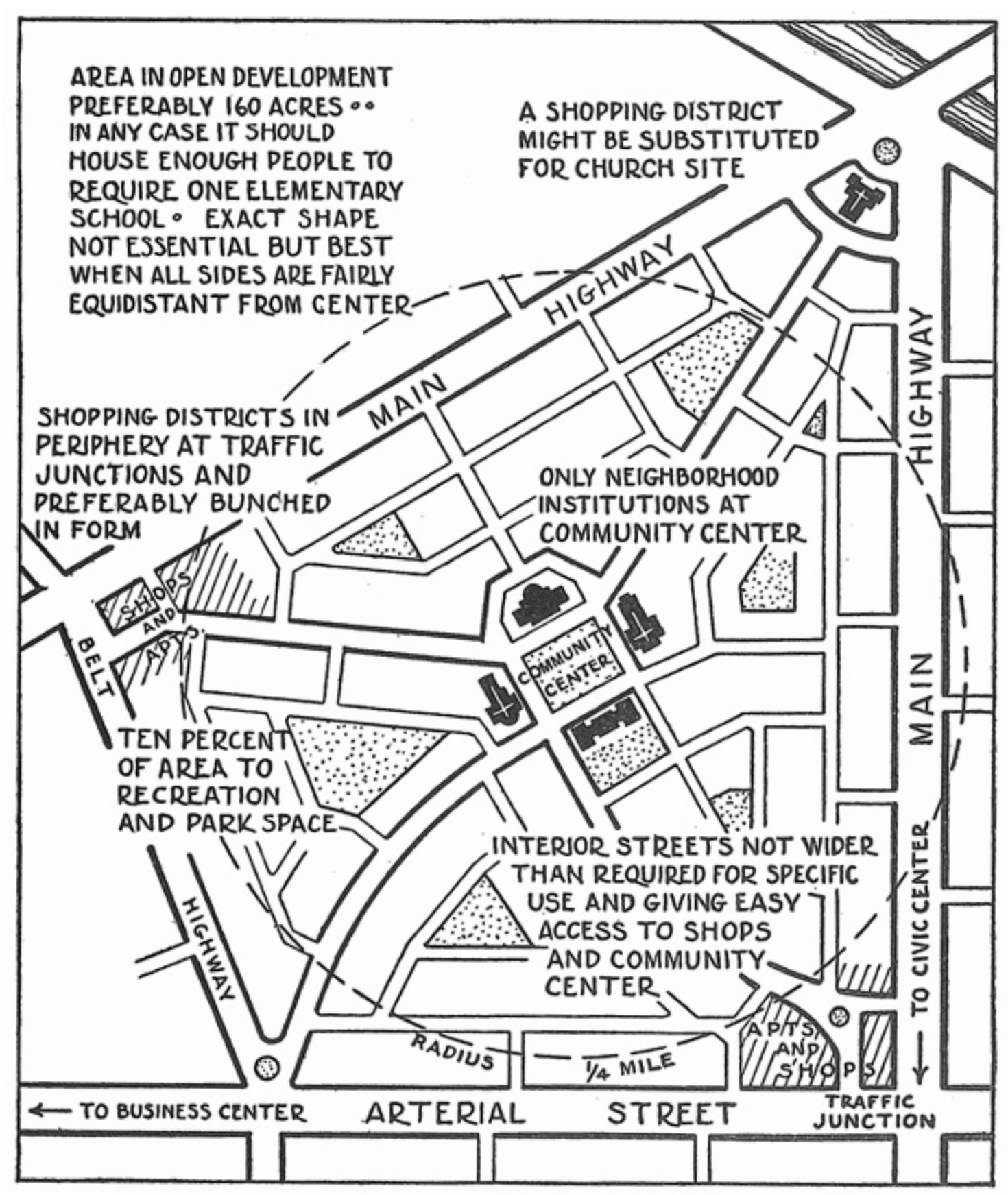


15 Clarence Perry, "“The Neighbourhood Unit" from The Regional Plan of New York and Its Environs."

1929. In The Urban Design Reader, ed. Michael Larice and Elizabeth Macdonald (London: Routledge, 2007), 176

16 Michael David Martin, "Returning to Radburn," Landscape Journal 20, no. 2 (2001): 158-159

17 Andrew Blauvelt, Tracy Myers, Katherine Solomonson, "Introduction," in Worlds Away: New Suburban Landscapes, ed. Andrew Blauvelt ( Minneapolis: Walker Art Center, 2008), 12
Perry's neighbourhood unit principles were most successfully carried out in the 1928 scheme for Radburn, New Jersey by planner Clarence Stein. (Figure 3 and 4) The design for Radburn followed through with its intention to create a strict separation of pedestrian and vehicular activities. The most important legacy of Radburn, however, was its emphasis on the notion of the "park as a backbone." 15 In this scheme, the park essentially replaced the street as the public pedestrian realm, a wholly revolutionary concept that should not be overlooked. In a recent article reevaluating the legacy of the Radburn plan, Michael David Martin explains,

"He [Stein] had intended for Radburn's park to be not just safe passage for children to and from school and between neighboring homes, but for the park to become the social matrix for family members who would only rarely have occasion to venture beyond the community's limits. In other words, the park was meant to displace the street, and the only role left for the street was one of service access and car storage. ${ }^{\prime 16}$

\section{Although Perry's diagrams and Stein's}

Radburn plan were conceived of in 19281929, the slowing of development due to the 1930s depression and World War II prevented widespread impact until after the war. In the next chapter, it will become clear that the use of landscape as a social organizing principle and an emphasis on the safety of children did persist in postwar incarnations of suburbia.

Thus, suburbia was built on the pursuit of individualism, privacy, and a desire to live in greater harmony with nature. The contributors of Worlds Away: New Suburban Landscapes (2008) explain:

"The problem with end-of-suburbia theses is that they forget the most powerful thing about suburbia - its symbolism and the idealism associated with it." ${ }^{17}$

\section{As previously expressed, younger} generations of people are less tied to this ideology than previous generations. However, the appeal of the single-family home is still sought after by young families. Any future interventions must respond to, and enrich these existing conditions, rather than simply disregard them. 


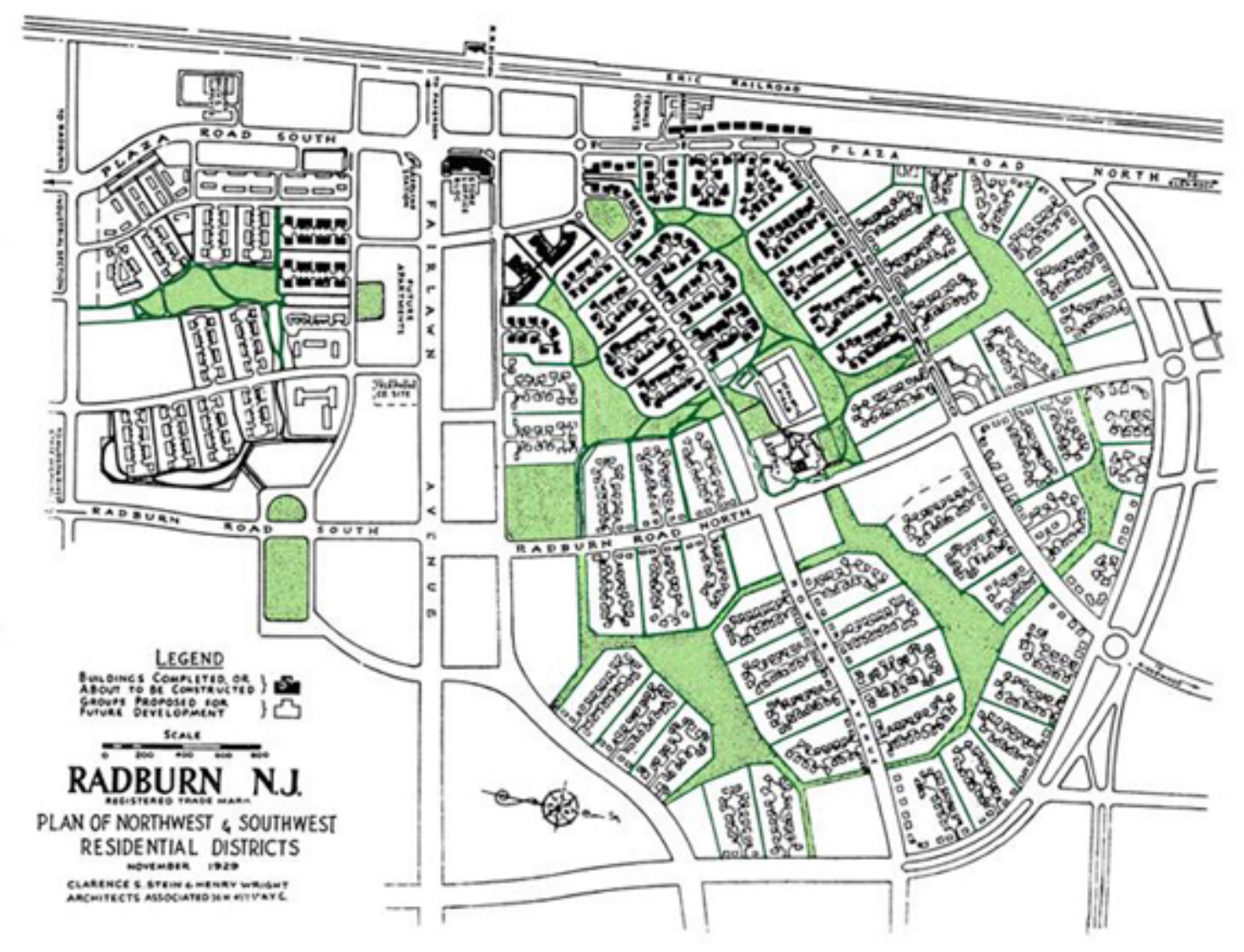

Figure 3: Clarence Stein's Plan for Radburn, NJ (1928)

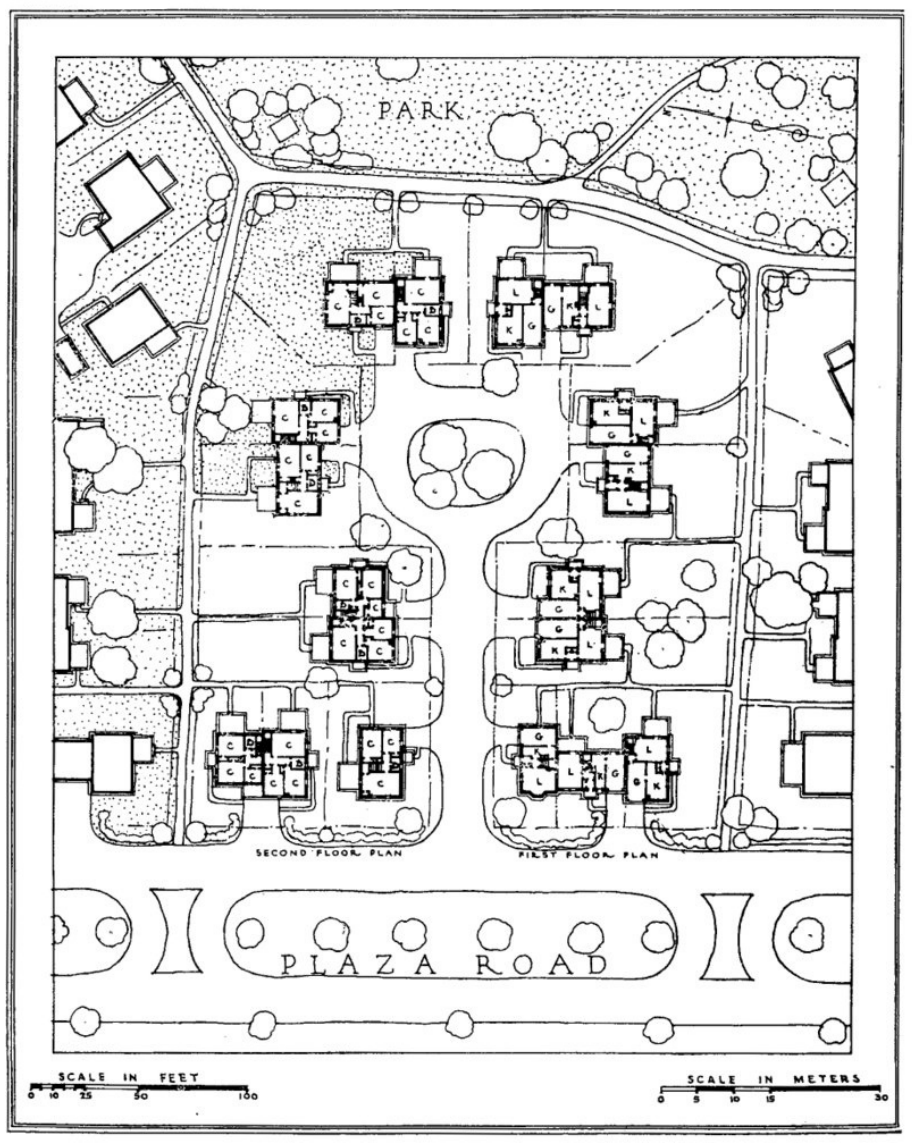

Figure 4: Plan of a cul-de-sac in Radburn, NJ 


\section{CHAPTER 1.2 \\ HISTORY AND ANALYSIS OF POSTWAR SUBURBS}

Although suburbanization was occurring long before World War II, the development which took place after 1945 was a unique incarnation. In the case of prewar suburban development, the scale and location were largely determined by public transportation such as trains and streetcars, and these communities were generally more walkable. In the postwar age, the automobile was thoroughly embraced as the future of transportation. This gave residents more mobility and allowed planners to create greater distances between uses. This fact is cited as being one of the major differences between prewar and postwar suburbia. Several critiques seem to triumph the former and abhor the latter, suggesting that suburbia had not delivered on its initial potential. However, while the influence of the car did mark a huge shift in suburban development, many of the intentions of earlier suburbs

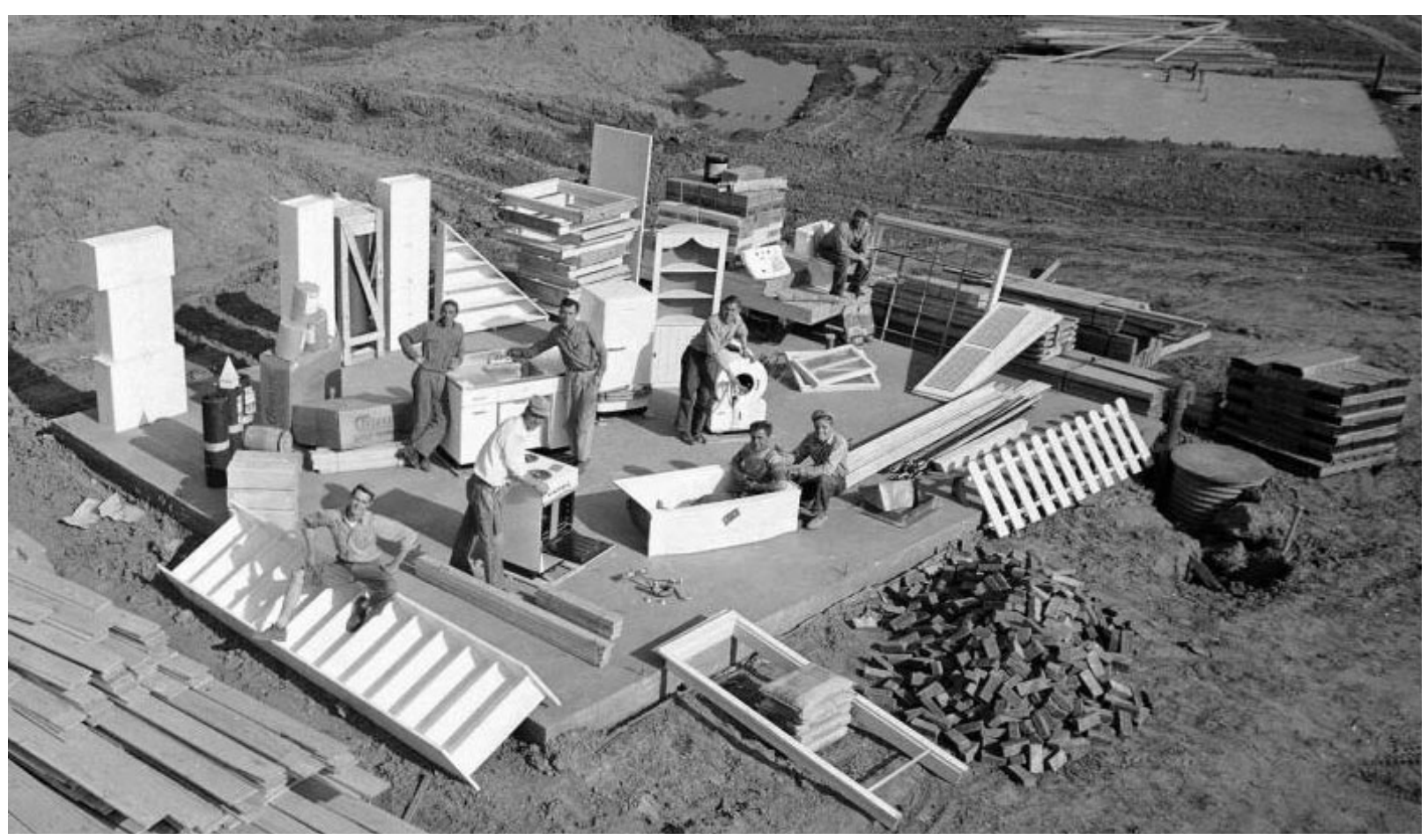

Figure 1: A photograph from a Levitt and Sons brochure for Levittown 
(ie. safety, privacy, embrace of nature) were carried through. The primary difference was the impact of modernity and the technological development brought on by the war effort. Wartime encouraged the development of technology in order to produce vehicles, aircrafts, munitions etc. After the war, industries were forced to change their focus. After decades of little to no construction, an enormous housing demand was created by veterans rapidly returning from overseas, and women leaving wartime jobs to become wives and mothers. This challenge was combatted with the same strategy as the war effort mass production.

Mass production of housing allowed for both quick delivery and affordability for the middle class customer. This process made the "American Dream" all the more accessible. The scale and speed at which suburban development grew was fed by the enthusiasm of its consumers. In The Suburb Reader (2006), editors Becky Nicolaides and Andrew Wiese explain:

"Americans embraced the postwar suburban way of life with great fervor and enthusiasm. They waited in lines to buy homes, They boasted of new ways to keep house. They participated actively

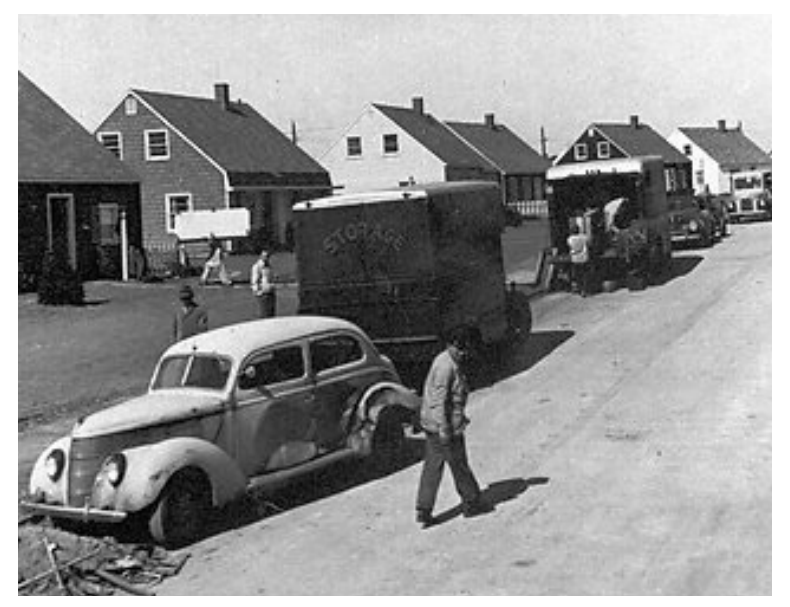

1 Becky Nicolaides and Andrew Wiese, The Suburb Reader (New York: Routledge, 2006), 259
Figure 2: New residents move into their Levitt homes in Levittown, N.Y. (October 1947)

in their communities. Both literally and metaphorically, they bought what was being sold. Clearly, postwar suburbia touched a vital nerve in America. ${ }^{\prime 1}$

After times of hardship, North Americans sought to live a traditional and simple way of life, but this lifestyle was delivered to them through modernist design.

Federal policies in both Canada and the US thoroughly encouraged suburban development through the promotion of housing loans, the rezoning of greenfield sites, and investment in the construction of highways. In Canada, this was achieved through the work of the Central (later Canada) Mortgage and Housing Corporation ( $\mathrm{CMHC}$ ), and its effort to deliver modern suburban living to middle- 
2 Richard Harris, Creeping Conformity: How Canada Became Suburban, 1900-1960 (Toronto: University of Toronto Press, 2004), 125 class families through affordable house plans and National Housing Act loans.

As indicated previously, it was in the postwar period that the influence of Radburn and Clarence Perry's neighbourhood unit model was fully explored, particularly in terms of zoning and separation of automobile and pedestrian traffic. Richard Harris explains:

"Zoning became part of a modernizing vision that sought to create a tidy, rational, planned environment. Planners recognized that suburbs would contain all types of land use, but they believed that each should have its own place. Separating houses, offices and industry, they also stripped residential areas of anything other than dwellings, schools, and the occasional church, compelling residents to do even convenience shopping by car."2

This model was popular because of the enormous demand for housing and community planning for young families. However, because of the often singleminded focus on single-family housing, the civic, retail and apartment type housing (which was originally promoted by Perry) were largely excluded from development. This was also due to the influence of the automobile. Although Perry was responding to the growing dominance of the automobile in the late 1920s, he could not have predicted the extent of its impact twenty years later. The importance of a walkable distance to local amenities was lost. Nonetheless, the services that did take precedence in the neighbourhood were schools, parks, and sometime churches. Although the domain of the adult did not need to be walkable (now that they had a car), the domain of the child certainly did. In the postwar period, the safety and comfort of children was of the utmost importance. Schools and parks were made accessible via pedestrian paths so that children would never have to cross arterials. This intention is consistent across all postwar suburbs in Canada, including the community of Rathwood/Applewood in Mississauga, the selected site for this thesis investigation. In this instance, a pedestrian trail system along Little Etobicoke Creek ties the suburban neighbourhoods together, and schools are distributed across residential areas. (Figure 3) It would seem that there is a network of spaces that is accessible from residential areas. It is the landscapes that serve as a physical organizing principle, thus continuing the ideology of the suburb which celebrates access to nature. 


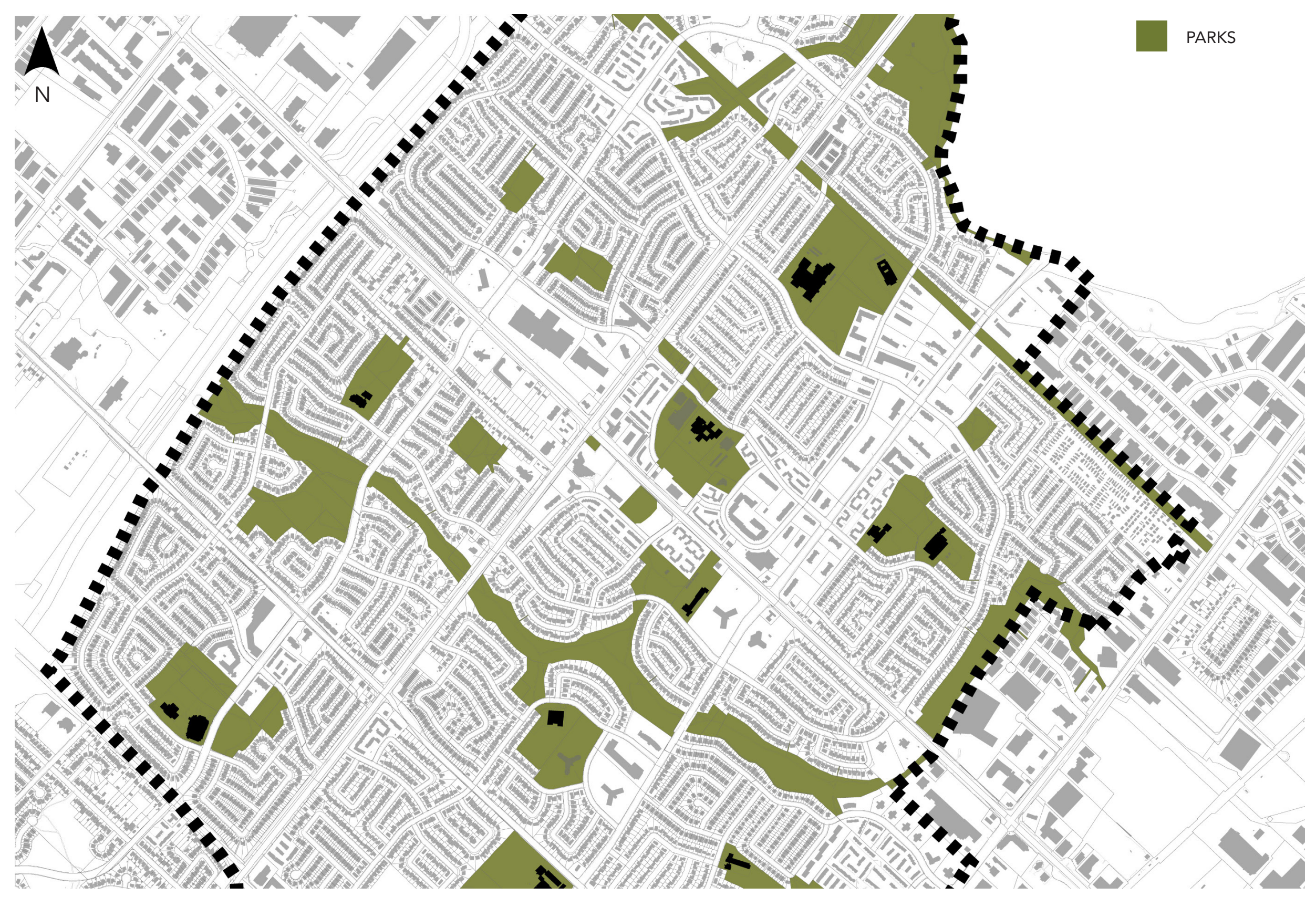

Figure 3: System of parks and schools in the Rathwood/Applewood neighbourhood in Mississauga 
3 Smiley, David, "Suburban Rhetorics: Planning and Design for American Shopping, 1930-1960." In Making Suburbia: New Histories of Everyday America, ed. John Archer, Paul J. P. Sandul, and Katherine Solomonson (Minneapolis: University of Minnesota Press, 2015), 146

4 Malcolm Gladwell, "The Terrazzo Jungle." In Worlds Away: New Suburban Landscapes, ed. Andrew Blauvelt (Minneapolis: Walker Art Center, 2008), 216

5 Margaret Crawford, "Suburban Life and Public Space." In Sprawl and Public Space Redressing the

Mall, ed. David J. Smiley (Washington, D.C.: National Endowment for the Arts, 2002), 24

6 Worlds Away: New Suburban Landscapes, ed. Andrew Blauvelt (Minneapolis: Walker Art Center, 2008), 217

7 Lizabeth Cohen, "From Town Center To Shopping Center: The Reconfiguration Of Community

Marketplaces In Postwar America." The American Historical Review 101, no. 4 (1996): 12
Since it was no longer important to have local retail amenities within walking distance, there was a need for a new typology for commerce. In the early years of postwar suburbia, residents continued to rely on the central city for their shopping needs. However, this was increasingly perceived as a negative experience, consistent with the belief that city streets were congested and unsafe. This desire to provide an alternative shopping experience began with "park and shop" strip plazas as early as the 1930s. ${ }^{3}$ In some cases this plaza model evolved into larger openair pedestrian shopping centres, but its popularity was nothing compared to the self-contained interior shopping mall. By the mid-1950s a new form of marketplace was created for the suburban environment: the shopping centre

Many sources credit architect Victor Gruen as the inventor of the shopping mall. Gruen immigrated to the United States from Vienna in 1938. ${ }^{4}$ He sought to emulate the vibrancy of shopping culture in European cities into a new typology, which was free from the grit of the city. ${ }^{5}$ Gruen's first experiment in this unique typology was the Southdale Shopping Centre in Edina, Minnesota, built in 1956. This model was
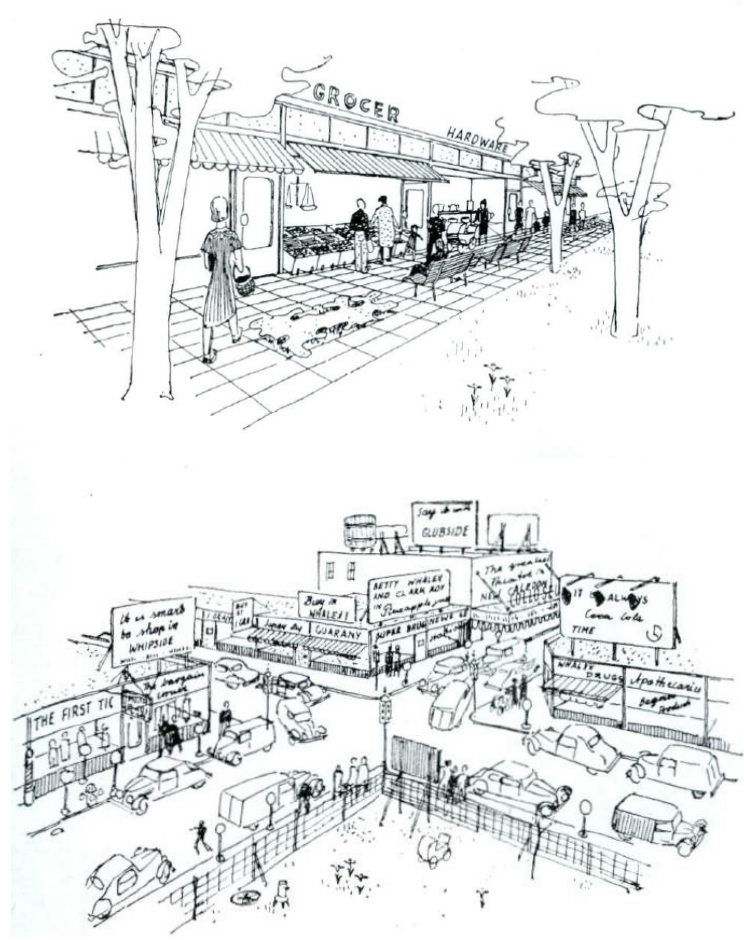

Figure 4: Sketches by Willo von Moltke of the modern shopping street versus the historic. (1946)

extremely influential on future mall design. As Malcolm Gladwell states in "The Terrazzo Jungle" (2004), "Gruen didn't design a building; he designed an archetype." 6 But Gruen saw the mall as more than just a shopping center. He saw it as a the central organizing entity of suburban communities. Gruen discussed the role of shopping centres as 'suburban crystallization points for suburbia's community life. ${ }^{17}$ In his original plans for Southdale, he intended 
for the shopping centre to be surrounded by "apartment buildings, houses, schools, a medical center, a park, and a lake". ${ }^{8}$ In the end, these other uses were never built, and shopping malls were characteristically surrounded by seas of parking. Herein lies the missed potential of postwar shopping malls. The way Gruen had imagined it, the mall could be a catalyst for a new form of city, a public space which would be a modern manifestation of the marketplace, extending the legacy of the Greek agora and Victorian gallerias. In her article "Suburban Life and Public Space," Margaret Crawford explains:
"He saw mall design as a way of producing new town centers or what he called "shopping towns." Thus he encouraged mall developers to include in their plans as many non-retail functions as possible, adding cultural, artistic, and social events. He called this integration of commerce with community life "environmental architecture."

To some extent, the shopping mall did provide a place for community activity. Unfortunately, because of its disconnection from residential areas, and limited mix of uses, it never succeeded in rivaling the urban conditions of the city in terms of public space.

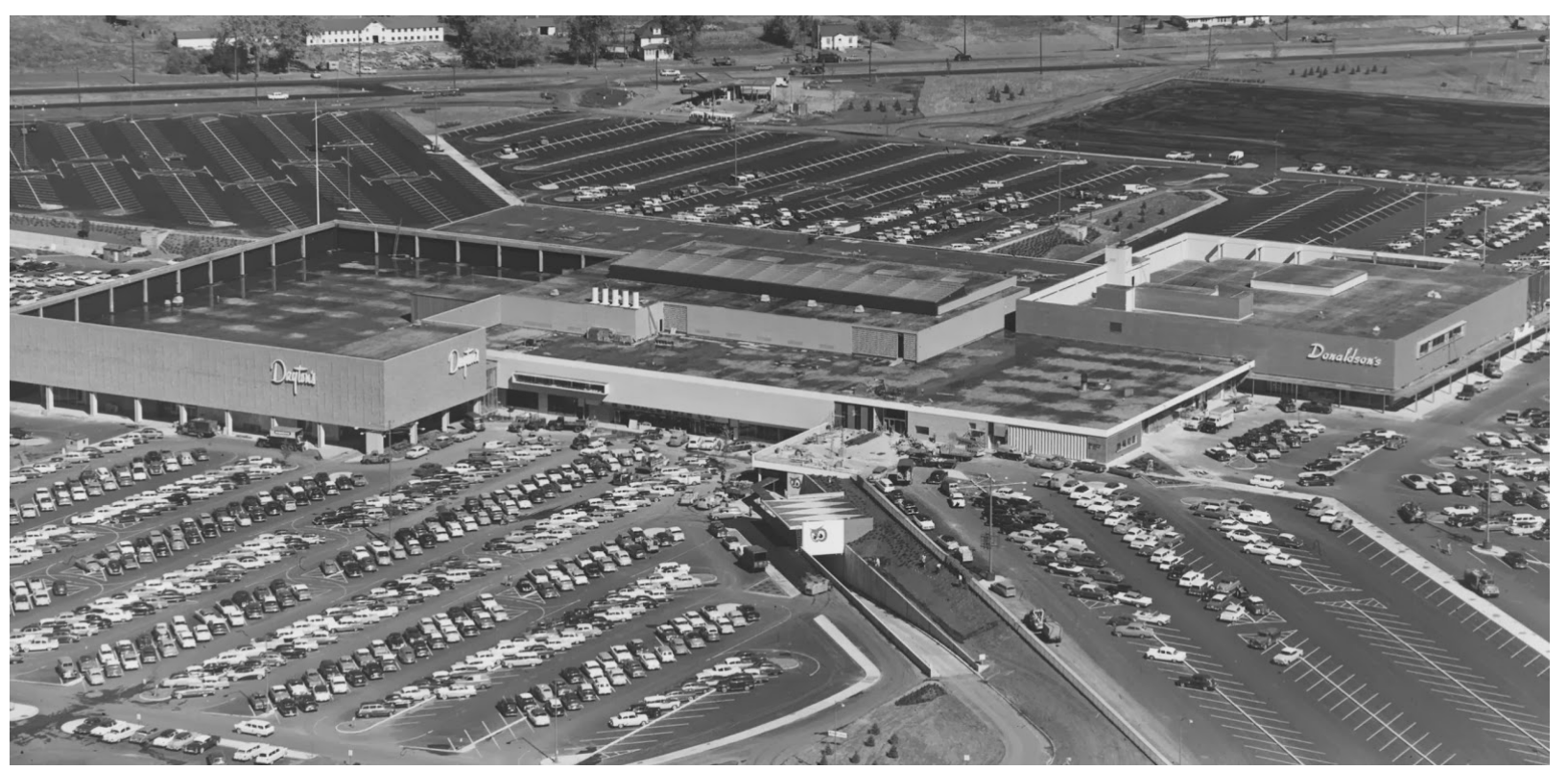

Figure 5: Aerial Photo of Southdale Shopping Center in 1956 
With its focus on providing ample greenspace, strict separation of uses, design for the automobile, and use of mass production, it is clear that postwar suburbia was truly a modernist phenomenon.

Despite this fact, within each of the influential models (by Howard, Perry, and

Gruen), there was a real attempt to create a central, pedestrian public realm. Howard's Garden City model, although intentionally diagrammatic, never achieved a central civic node as intended. Perry's neighbourhood unit model, although influential on the arrangement of streets, parks and schools, was not carried through in terms of walkable access to local amenities like shops and civic buildings. Gruen proposed a new 'civic heart' which would become the focal point of the suburban community, but the omission of additional uses in close proximity prevented this from occurring. This consistent thread suggests that the fundamental building blocks of postwar suburbia - its parks, schools, and shopping centers - have the potential to take on roles as active urban nodes, without compromising the character of the surrounding residential neighbourhood.

Within the selected community of Rathwood/Applewood in Mississauga, the 'community node' at Burnhamthorpe and Dixie could become the major core amongst a system of smaller local nodes. (Figure 7 and 8). This would ensure greater walkability across the area, and produce a more gradual gradient of density from the major intersection outward. 


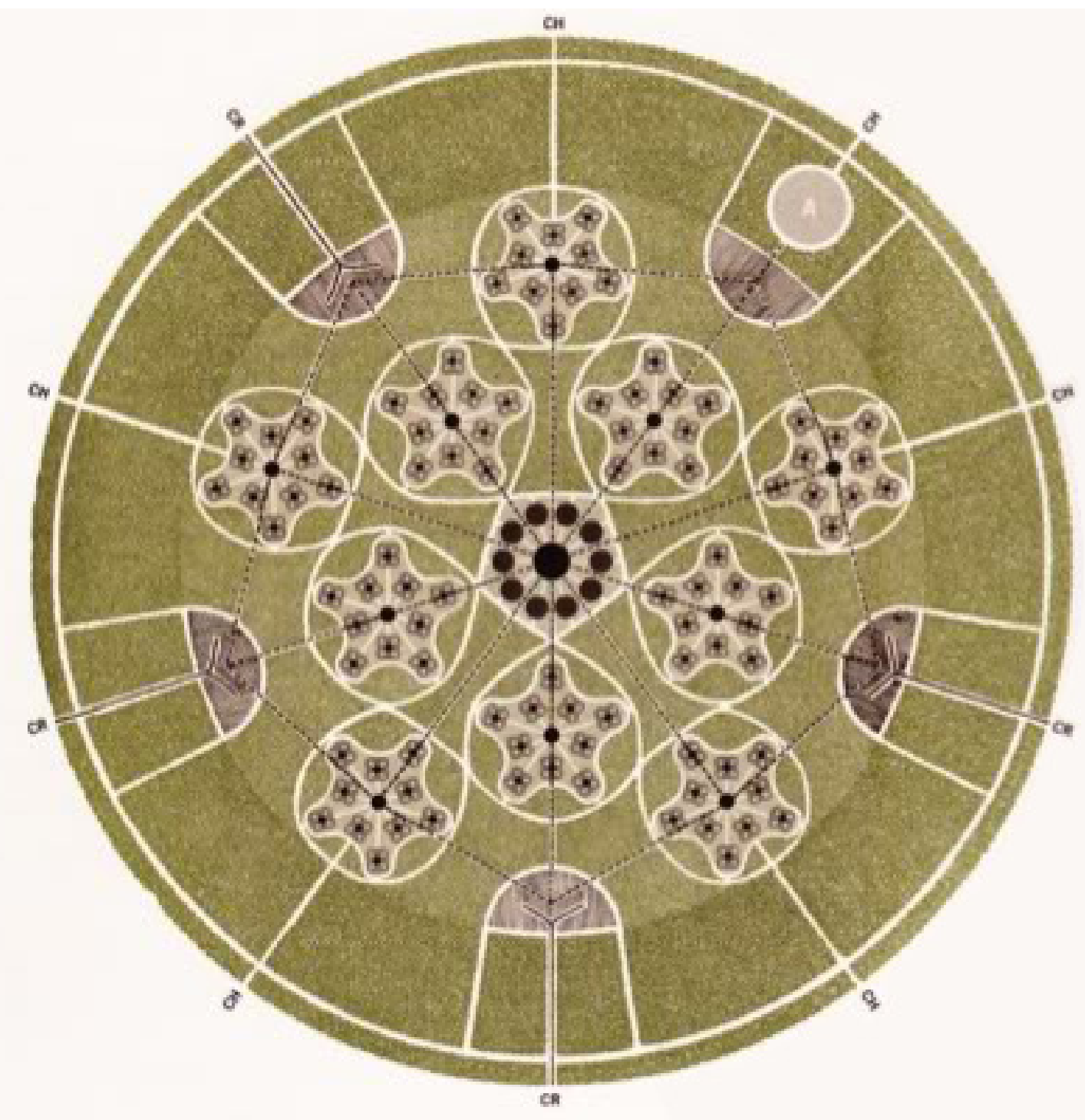

Figure 6: Victor Gruen's "Schematic Drawing of the Cellular Metropolis of Tomorrow" from The Heart of Our Cities: The Urban Crisis: Diagnosis and Cure (1964) 


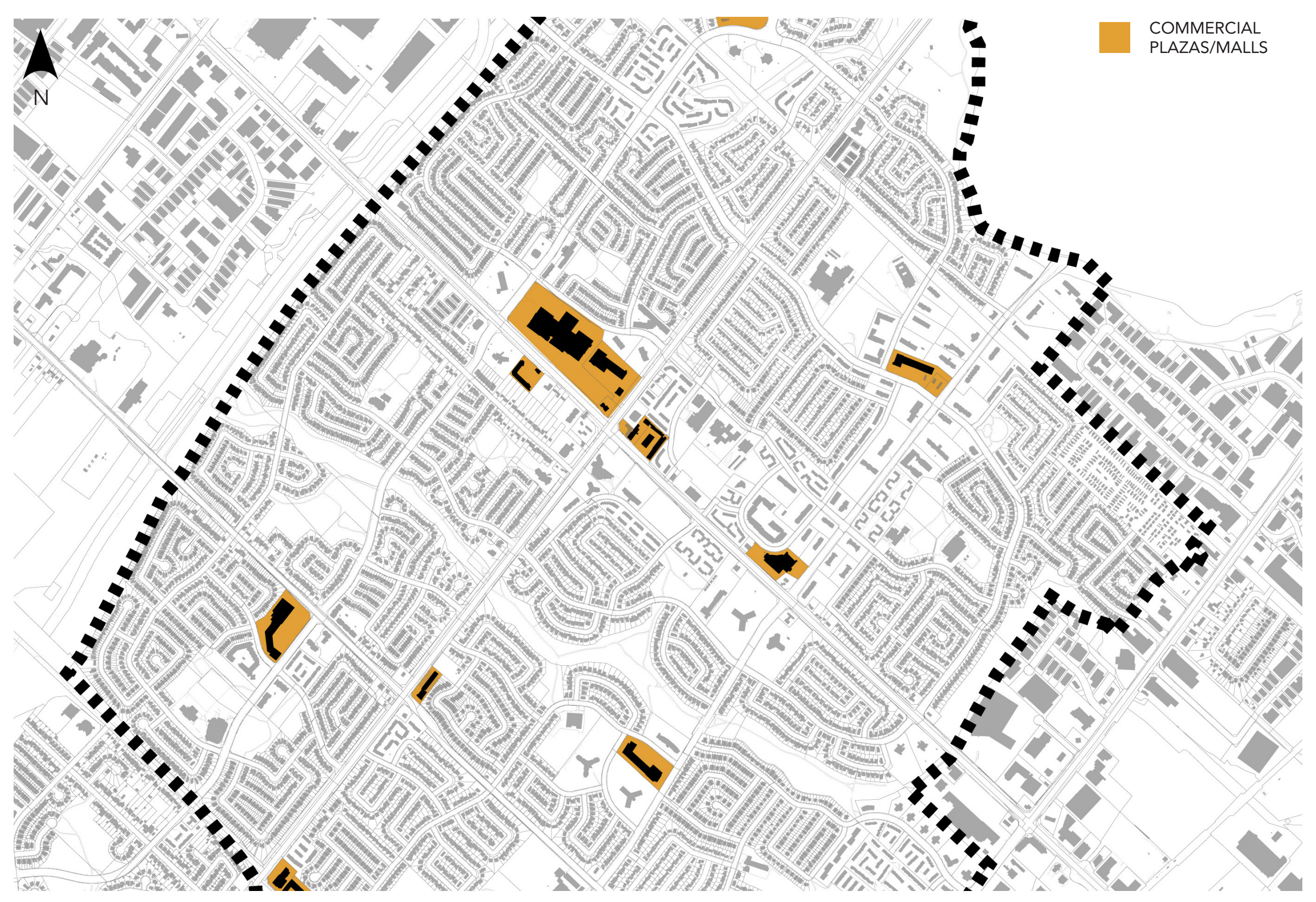

Figure 7: Commercial Plazas in the Rathwood/Applewood neighbourhood in Mississauga 


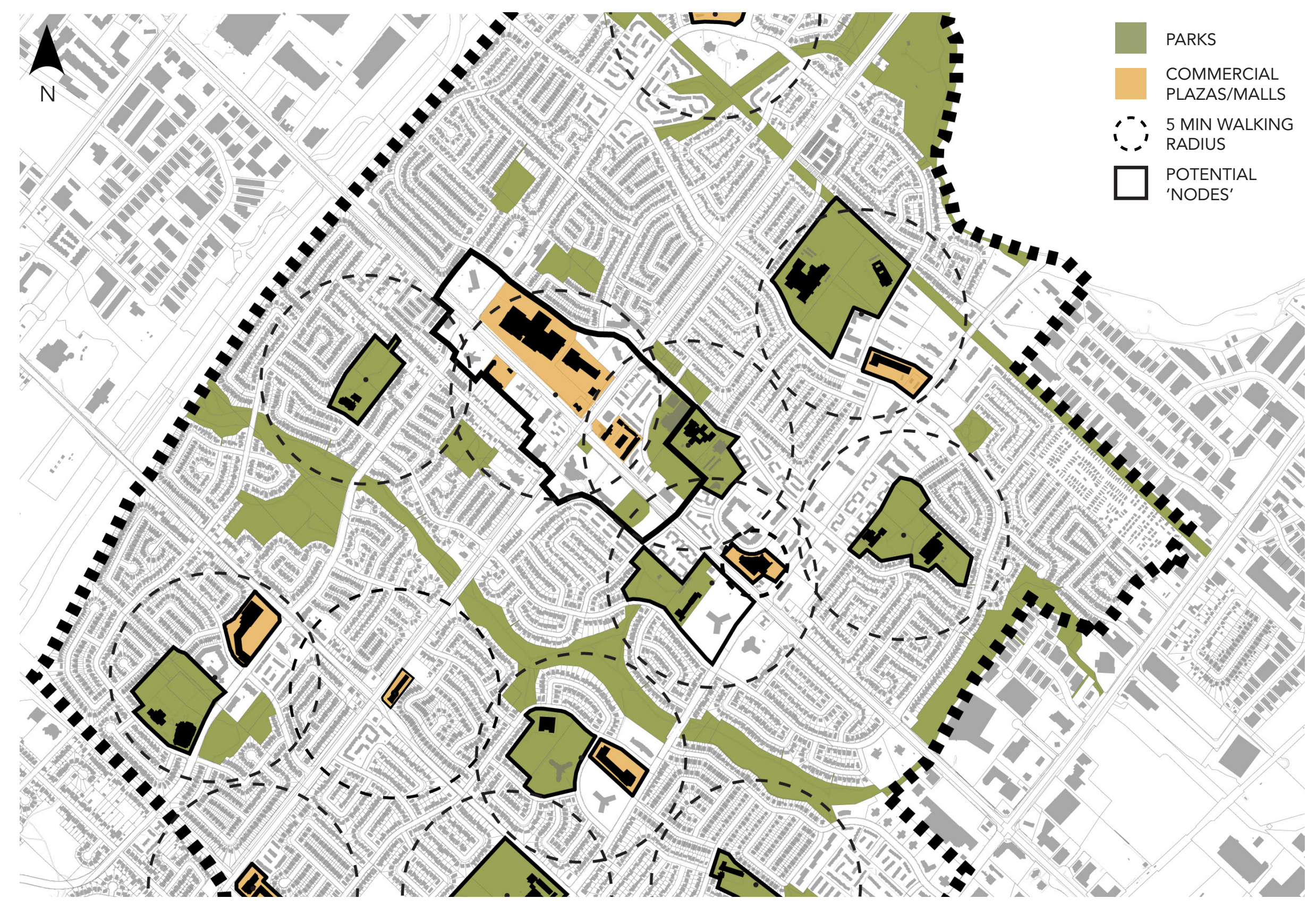

Figure 8: Potential 'urban nodes' within the Rathwood/Applewood neighbourhood in Mississauga 


\section{PART 2: CRITIQUES OF MODERNISM \& SUBURBIA}

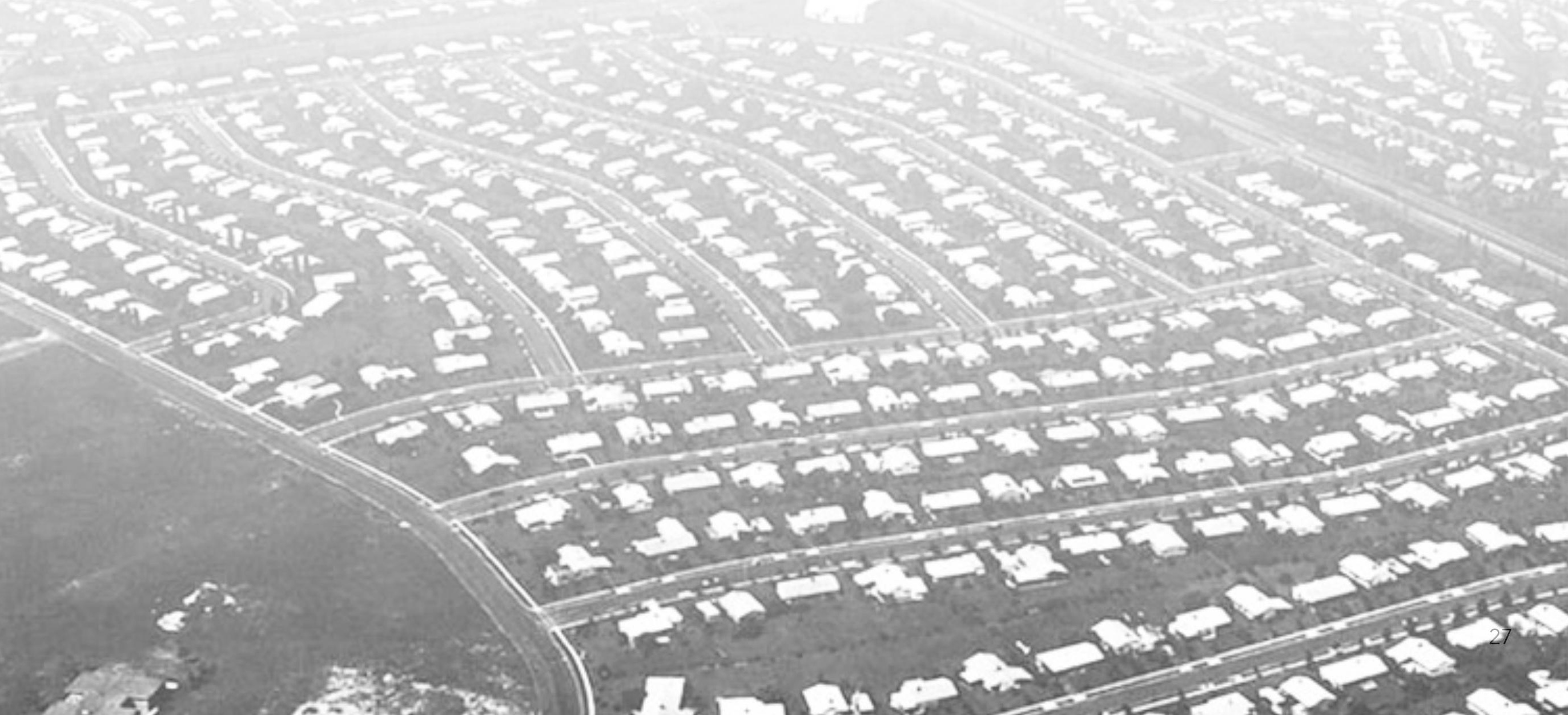


1 Robert Bruegmann, Sprawl: A Compact History (Chicago: University of Chicago Press, 2005), 121

2 Lewis Mumford, "Suburbia and Beyond" in The City in History: Its Origins, Its Transformations, and Its Prospects (New York: Harcourt, Brace \& World, 1961) 510

3 James Howard Kunstler, The Geography of Nowhere: The Rise and Decline of America's Manmade Landscape (New York: Simon \& Schuster, 1993) 10

4 Robert A. Beauregard, When America Became Suburban (Minneapolis: University of Minnesota Press, 2006), 138

5 Lewis Mumford, " "The Garden City Idea and Modern Planning" From the 1946 Introduction to Garden Cities of To-Morrow." 1902. In The Urban Design Reader, ed. Michael Larice and Elizabeth Macdonald (London: Routledge, 2007), 46

6 lbid, 47

$7 \mathrm{lbid}, 50$

\section{CHAPTER 2.1 \\ CRITIQUE OF SOCIOLOGY}

The previous chapters have introduced the integral relationship between the phenomenon of postwar suburbanization and the embrace of modernist architecture and planning. Due to its use of technology and mass production, modernism was the most practical strategy to build at the scale and quantity that was needed. Thus it was heralded as a 'heroic' strategy. However, as the initial enthusiasm for postwar growth began to wane, criticism of suburban development was burgeoning. By the mid1950s urban professionals began expressing their distaste for decentralization. ${ }^{1}$ Historian Lewis Mumford was one of the most vocal opponents. His work, The City in History: Its Origins, Transformations, and its Prospects (1961), consists almost entirely of rants about the negative effect of the automobile on urbanism with excerpts like,

"The absurd belief that space and rapid locomotion are the chief ingredients of a good life has been fostered by the agents of mass suburbia." ${ }^{2}$

Mumford viewed this environment as wholly demoralizing to mankind. ${ }^{3}$ He regarded suburbs as intellectual and cultural wastelands, which practiced conformity over individual thought. ${ }^{4}$

In this light, it is surprising that Mumford wrote the introduction to the 1946 edition of Ebenezer Howard's The Garden Cities of To-Morrow (1898). In this introduction entitled "The Garden City Idea and Modern Planning," Mumford indicates great respect for the intentions of this model, rather than the actual built communities which were based on the idea. ${ }^{5}$ Mumford argues that the potential of these aspirations was not adequately met, stating:

"The Garden Cities of To-Morrow has done more that any other single book to guide the modern town planning movement and to alter its objectives. But it has met the traditional misfortune of the classic: it is denounced by those who have plainly never read it and it is sometimes accepted by those who have not fully understood it."

He asserts that "The Garden City, as Howard defined it, is not a suburb but the antithesis of a suburb: "not a more rural retreat, but a more integrated foundation for an effective urban life."7 This is an interesting conclusion which implies that the 


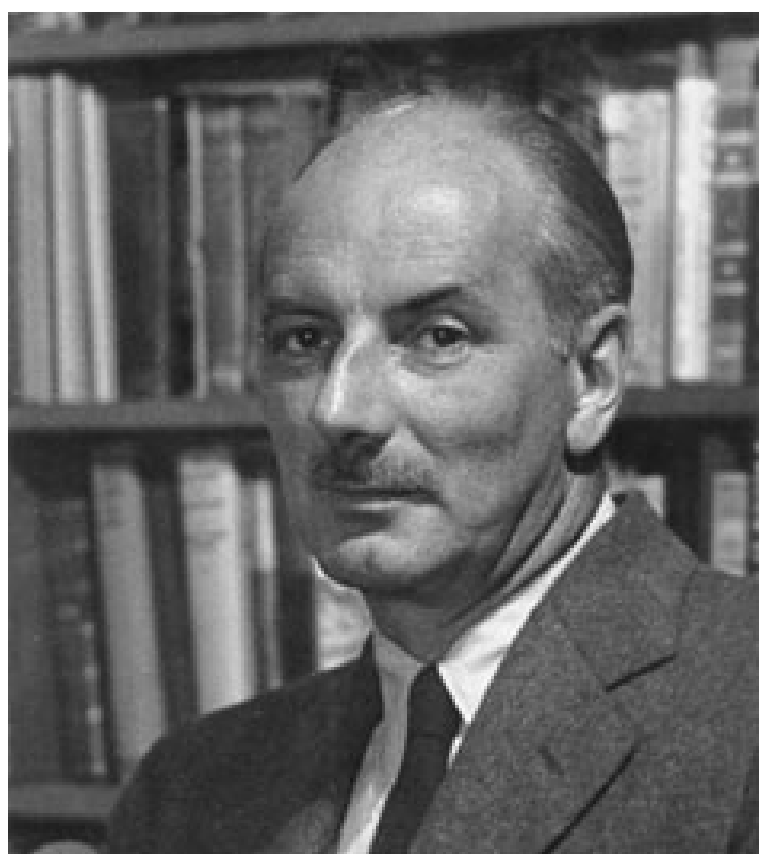

Figure 1: Urban critic Lewis Mumford

introduction of the automobile completely changed the game. However, some confusion lies in the fact that Howard's ideas of zoning and separation of uses are considered foundational to the modernist urban planning of which he is highly critical.

\section{Concurrent with Mumford's}

discourse, urbanist and planner Jane Jacobs was also a vocal critic the 'evils' of suburbanization. Her critique focused on the lack of pedestrian street-life and mixed uses in modernist planning. In her writings, Jacobs championed the city for

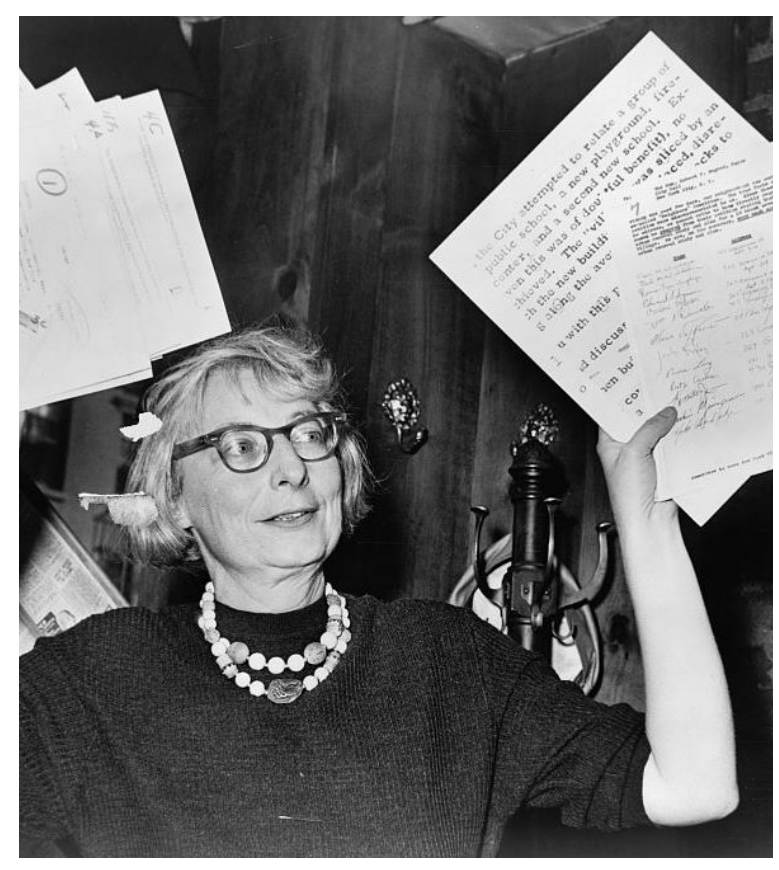

Figure 2: Urban critic Jane Jacobs

providing residents and visitors with an "informal public life," 8 which is fostered by a close proximity of strangers and a mix of amenities. Jacobs advocated for the conservation of small-scale pre-war built fabric which promoted this activity, and argued that modernist environments lacked character. Naturally, she was equally critical of high-rise urban renewal projects which followed a the model of Le Corbusier's 'Radiant City'. (Figure 3) In the introduction to The Death and Life of Great American Cities (1961), Jacobs states, 
9 Jane Jacobs, The Death and Life of Great American Cities (New York: Vintage Books, 1992), 6-7

$10 \mathrm{lbid}, 7$

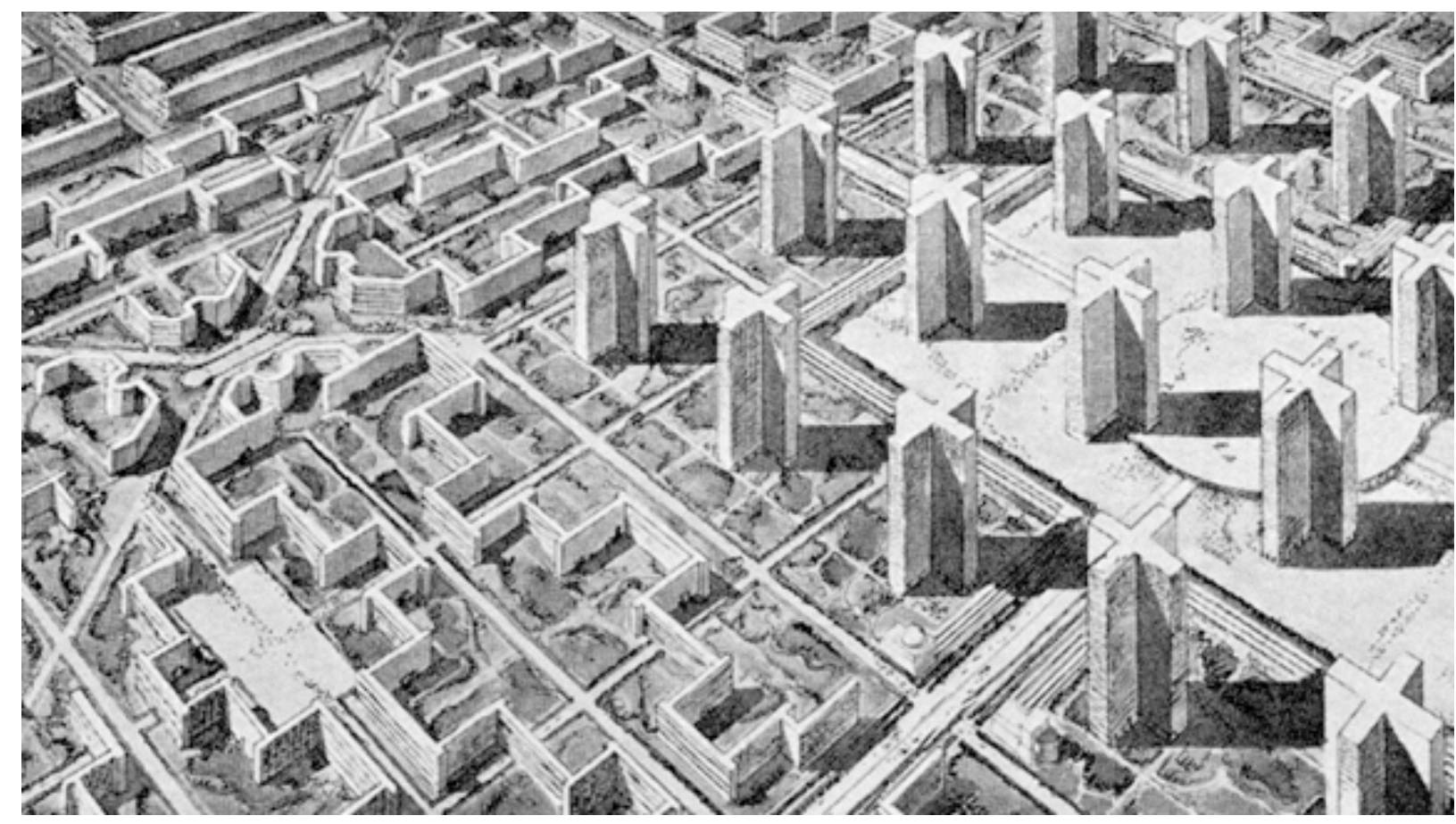

Figure 3: Le Corbusier's Sketch for "The Radiant City" (1924)

"If it appears that the rebuilt portions of cities and the endless new developments spreading beyond the cities are reducing city and countryside alike to a monotonous, unnourishing gruel, this is not strange. It all comes, first-, second-, third or fourthhand, out of the same intellectual dish of mush, a mush in which the qualities, necessities, advantages and behavior of great cities have been utterly confused with the qualities, necessities, advantages and behavior of other and more inert types of settlements."

Her use of the words gruel and mush, mirror Mumford's sentiment that suburbs are culturally, intellectually, and spatially inferior. Jacobs does not place as much blame on the automobile as Mumford, but suggests that modern planning strategies did not know how to properly deal with them, stating: "the destructive effects of automobiles are much less a cause than a symptom or our incompetence at city building." 10

Another influential voice of this mid-1950s to early 1960 s social critique 
was William H. Whyte with his work, The Organization Man (1956). Whyte's critique focused on the culture of conformity which was developing in suburban communities. The so-called 'Organization Men' were middle-class husbands and fathers who participated in corporate culture and typical suburban home life. This sentiment is consistent with David Riesman's The Lonely Crowd (1950) and Betty Friedan's The Feminine Mystique (1963), which painted postwar suburbia as an isolating and intellectually stifling environment.

These critiques had more to do with social conditions indicative of the cold war period, and the exclusive demographic of young white families. However, for critics and artists alike, this culture of conformity found its purest visual representation in the postwar suburbs, because of its use of mass-production and architectural uniformity. This opinion is best captured through the words of Malvina Reynolds' song Little Boxes (1962):

Little boxes on the hillside, Little boxes made of ticky tacky Little boxes on the hillside, Little boxes all the same.

There's a green one and a pink one And a blue one and a yellow one, And they're all made out of ticky tacky And they all look just the same. ${ }^{11}$
In this piece, Reynolds uses the identical appearance of suburban homes ("little boxes") as a metaphor for the conformist nature of suburban communities.

The common thread within these works is that they are fundamentally critiques of modernist environments. This discourse illustrates that the environment associated with modernity had shifted from the city to the suburbs. In her article "How Hell Moved from the City to the Suburbs," Becky Nicolaides suggests that as individuals attempted to escape the alienation and conformity of the city, modernity followed with them. ${ }^{12}$ In Bourgeois Utopias (1987), Robert Fishman draws similar conclusions. He finds it curious that these mid-century scholars had drawn entirely opposite conclusions than Frank Lloyd Wright's utopian vision for a "Broadacre City": "Where Wright saw the city as the heartland of conformity and decentralization as the path to renewed individualism, Riesman [The Lonely Crowd (1950)] and Whyte [The Organization Man (1956)] see decentralization as ultimately destructive of the density on which high culture depends." 13 Thus, there had been a complete reversal from a time when suburbia was considered the domain of the
11 Malvina Reynolds, Little Boxes (Schroder Music Company, 1962)

12 Becky Nicolaides, "How Hell Moved from the City to the Suburbs: Urban Scholars and Changing Perceptions of Authentic Community," in The New Suburban History, ed. Kevin Michael Kruse and

Thomas J. Sugrue (Chicago: University of Chicago Press, 2006), 82

13 Robert Fishman, Bourgeois Utopias: The Rise and Fall of Suburbia (New York: Basic Books, 1987), 201 


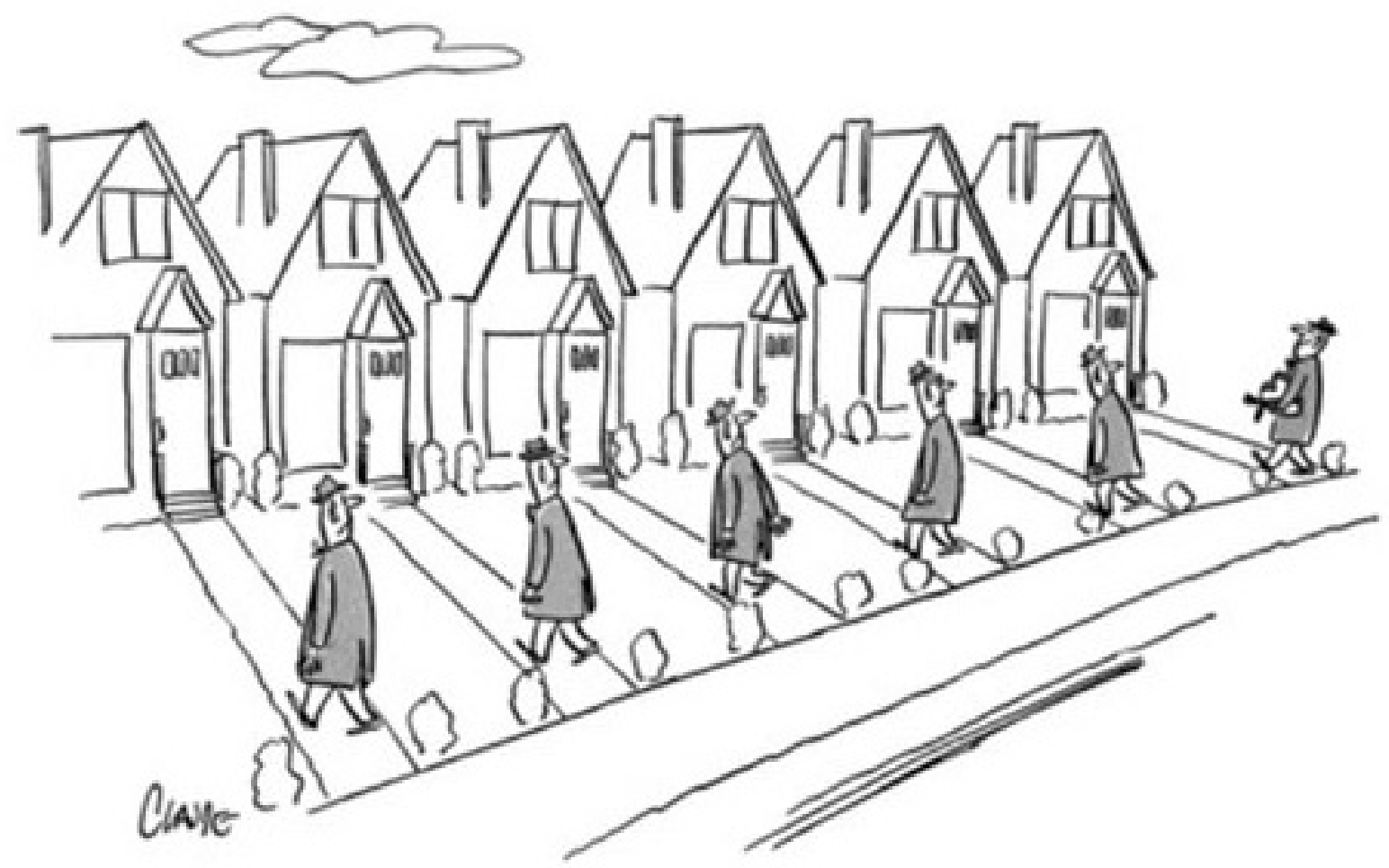

Figure 4: Cartoon Satire of Suburbia in the New Yorker Magazine 1958, Drawn by Claude Smith

bourgeoisie. It was now characterized by modernism - the language of the masses.

Within these discussions, two primary issues with suburban environments have emerged: architectural uniformity and lack of pedestrian-oriented public space. Naturally, these issues are synonymous with issues of modernist planning and architecture. 
1 Kevin Lynch, The Image of the City (Cambridge, Mass.: MIT Press, 1960), 9

2 lbid, 4

\section{CHAPTER 2.2 \\ CRITIQUE OF IMAGEABILITY}

The academic and popular critiques discussed in Chapter 2.1 commonly associated uniformity of culture with the uniformity of modernist architecture. Implicit in this discussion was an emerging desire for recognizable and distinct images in urban environments which orthodox modernist environments seemed to lack. This subject was first introduced by urban planner Kevin Lynch's 1960 work, The Image of the City, in which he coined the term "imageability" to characterize this phenomenon. Lynch defines imageability as,

"that quality in a physical object which gives it a high probability of evoking a strong image in any given observer. It is that shape, color, or arrangement which facilitates the making of vividly identified, powerfully structured, highly useful mental images of the environment. "1

Within his definition are five elements which make up the imageability of the city: nodes, paths, edges, districts, and landmarks.

(Figure 1) Lynch explains how these features constantly overlap one another, and are most effective at creating memorable images when found in combination.

Memorability is an important component of Lynch's discussion; he states:

"The image is the product both of immediate sensation and of the memory of past experience, and it is used to interpret information and to guide action." ${ }^{2}$

Within this framework, Lynch suggests that modernist places lack imageability because architectural forms are highly repetitive and/or banal, arterial streets are designed for vehicular speed over experience, and

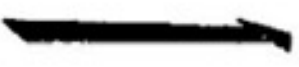

PATH

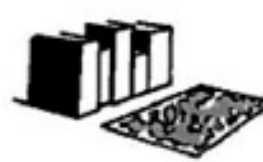

EDGE

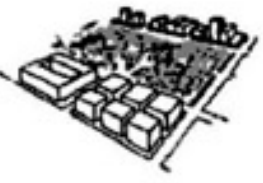

DISTRICT

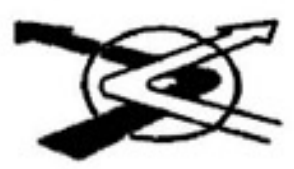

NODE

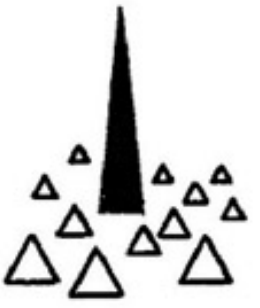

LANDMARK

Figure 1: Kevin Lynch's five points of "Imageability" from The Image of the City (1960) 
interior streets are non-hierarchical. This makes these spaces difficult to navigate as a pedestrian.

Following Lynch, Italian Architect Aldo Rossi published The Architecture of the City in 1966. In this work, Rossi responds more specifically to the role of architecture in defining places. Rossi distinguishes two critical typologies of urbanism which are housing (ie. the fabric buildings) and the monuments (similar to Lynch's 'landmarks'). He asserts that while both are important, the monuments are the 'urban artifacts' which contain the collective memories of a place. ${ }^{3}$ Rossi sees time as an important component in forming places, implying that incrementalism adds richness. Rossi's discourse suggests that modernist architects had forgotten these key principles of urban space. He argues that orthodox modernism does not articulate a hierarchy between fabric and landmark, or value the retention of existing built history.

\section{Similarly, in Collage City (1973)}

Colin Rowe suggests that incremental development of buildings and engagement with existing fabric is the key to imageable places. Rowe argues that the overlapping of buildings and spaces from various periods resulted in urban character. ${ }^{4}$ The work of Rossi and Rowe (among others) convinced many to appreciate the value of historic built fabric, and served source of inspiration for the historic preservation movement in North America. Unfortunately their ideology only applies to existing cities and not entirely new places. While smallscale incrementalism does appear to result in more complex and interesting places, the economies of scale and typologies of modern and contemporary times do not generally align with this objective. Their analyses reject the changes brought on by modernism, and suggest that this is a mistake that must be rectified.

Rather then simply reject modernism, Robert Venturi and Denise Scott-Brown's Learning from Las Vegas (1972) attempted to understand changing conceptions of identifiability caused by the creation of modernist environments. They refer directly to previous flaws with the statement:

"The students of urban perception and "imageability" have ignored them, and there is some evidence that the [Vegas] Strip would confound their theories. ${ }^{\prime 5}$

In this work, Venturi and Scott Brown use
3 Aldo Rossi and Peter Eisenman, "Editor's Introduction," in The Architecture of the City (Cambridge, Mass.: MIT Press, 1982)

4 David Rifkind, "Post Modernism: Critique and Reaction." In A Critical History of Contemporary Architecture 1960 -2010, ed. Elie Haddad, David Rifkind, and Peter L. Laurence ( Ashgate Publishing Group, 2014), 37

5 Robert Venturi and Scott-Brown, Learning from Las Vegas: The Forgotten Symbolism of Architectural Form. Rev. ed. (Cambridge, Mass.: MIT Press, 1977), 74 
6 Robert Venturi and Scott-Brown, Learning from Las Vegas: The Forgotten Symbolism of Architectural Form. Rev. ed. (Cambridge, Mass.: MIT Press, 1977), 87

7 lbid, 18
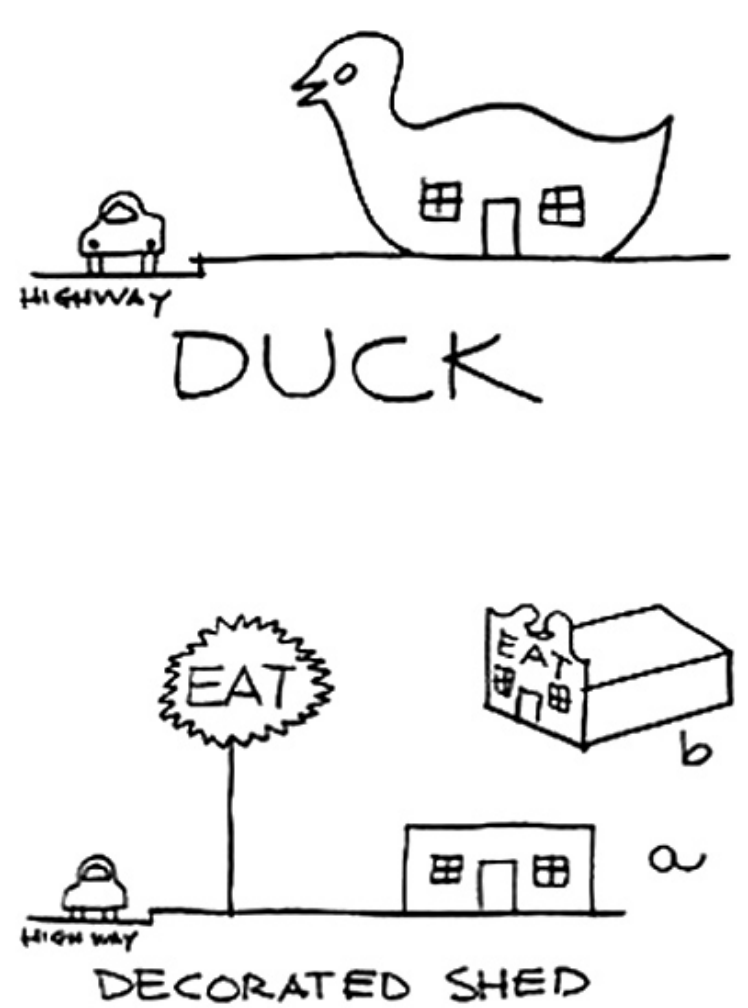

Figure 2: Sketches of the "duck" and "decorated shed" concepts from Learning From Las Vegas (1972)

an extensive analysis of the Las Vegas strip as a means to explore both the challenges and potential of modern expression.

The authors explain that while orthodox modernism would favour a minimal or complete lack of signage, the dominating consumer culture of the postwar age (best expressed through Las Vegas) had served to adapt the modern aesthetic in order to convey internal program. Venturi and Scott-Brown categorize the populist adaptation of modernist architecture into two models: "the decorated shed" and the "duck". The decorated shed has relegated all of its expression to its signage, leaving only a functionalist box, while the duck is an architectural form which becomes an object in itself. ${ }^{6}$ The authors suggest that commercialized modernism has made signs and symbols more important than architectural form itself, claiming that: "If you take the signs away, there is no place." Ultimately, Venturi and Scott Brown suggest that a sign or symbol can be a recognizable image in the same way that Lynch and Rossi speak of landmarks or monuments. Through Learning From Las Vegas, the complementary "Learning from Levittown" studio at Yale University, and later Venturi's Complexity and Contradiction (1966), the husband-and-wife team immersed themselves in the study of the "ugly and ordinary" and the culture of the everyday. Their strong interest in populism and 'Pop Art', led them to further investigate the "decorated shed" model. This intention can be seen most clearly in their 1979 design for a corporate headquarters for a scientific information services corporation in Philadelphia. Here they used a kinetic graphic pattern as a reference to 


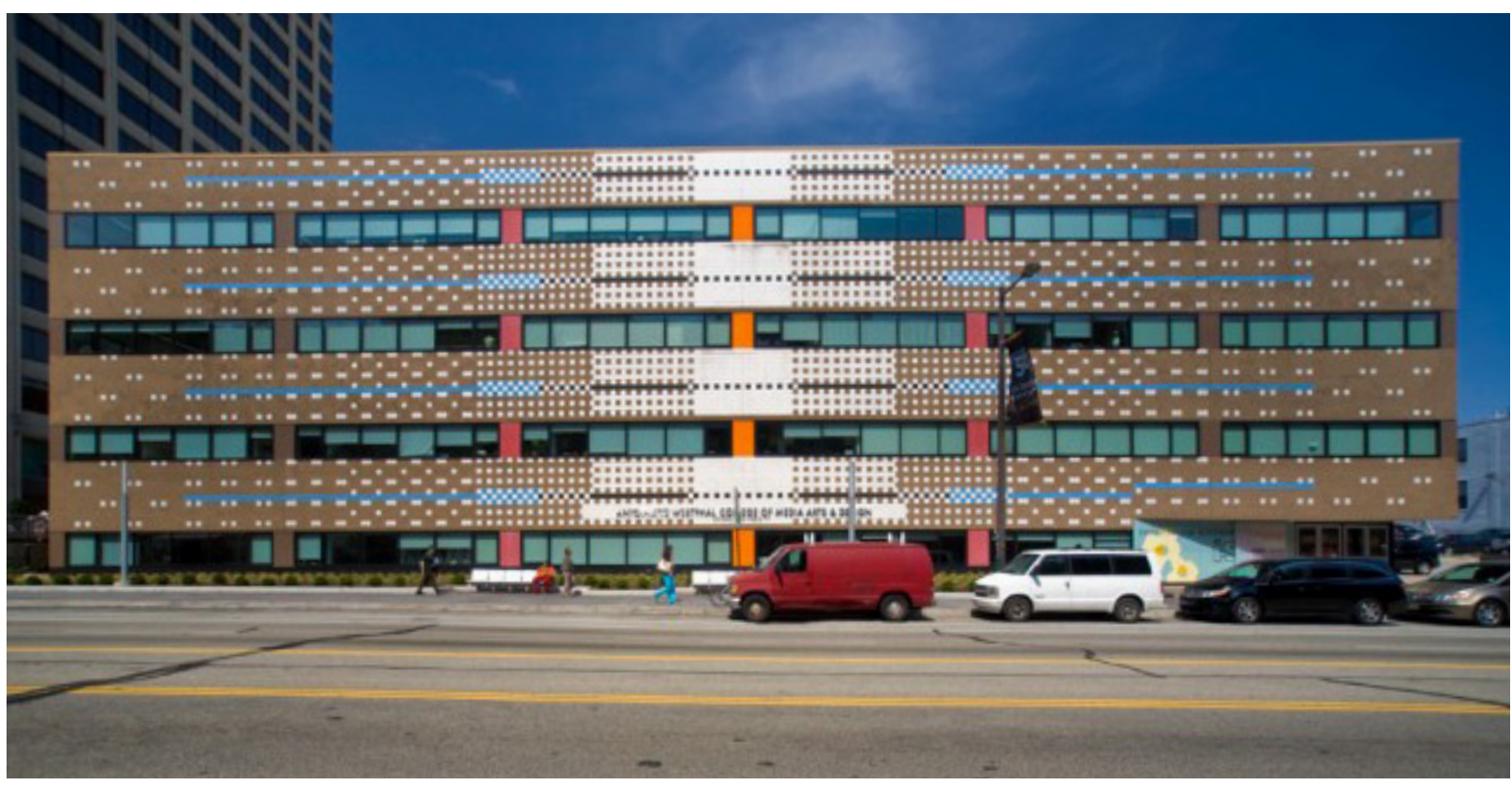

Figure 3: Venturi Scott Brown's ISI building in Philadelphia (now Drexel's URBN)

information technology, and show the predominance of image over form. ${ }^{8}$ (Figure 3)

Pop art was an artistic movement that emerged in the mid 1950s, in Britain and North America. In Pop Art: A Continuing History (1990), Marco Livingstone describes Pop art as:

"a resolutely Post-war form of realism dedicated to the dispassionate deification of the common object and to the manipulation of images and sign systems extracted ready-made from the mass media. Its use of this media - exclusively associated with a capitalist economy - has led to its being perceived as the reflection of a materialistic society saturated with images of itself and particularly of its hedonism and affluence in the postwar years. ${ }^{19}$

Much like the roadside signs studied in Learning From Las Vegas, Pop Art was a response to the commercialized culture of the modern world. It was a way of celebrating it as a form of communication and legitimate culture; through the elevation of low-culture to a platform of high-culture. Pop Art first met public attention through the work of the British
8 Richard Poulin, Graphic Design Architecture, a 20th Century History: A Guide to Type, Image, Symbol, and Visual Storytelling in the Modern World (Beverly, MA: Rockport Publishers, 2012), 185

9 Marco Livingstone, Pop Art: A Continuing History (London: Thames and Hudson, 1990), 15 
$10 \mathrm{Hal}$ Foster, "IMAGE BUILDING," Artforum International. 43, no. $2(10,2004)$

11 Simon Sadler, Archigram: Architecture without Architects (Cambridge, MA: MIT Press, 2005), 33

12 Dirk Van Den Heuvel. "Between Brutalists. The Banham Hypothesis and the Smithson Way of Life." The Journal of Architecture 20, no. 2 (2015): 293-308

13 Banham, Reyner. "The New Brutalism." October 136 (2011): 19
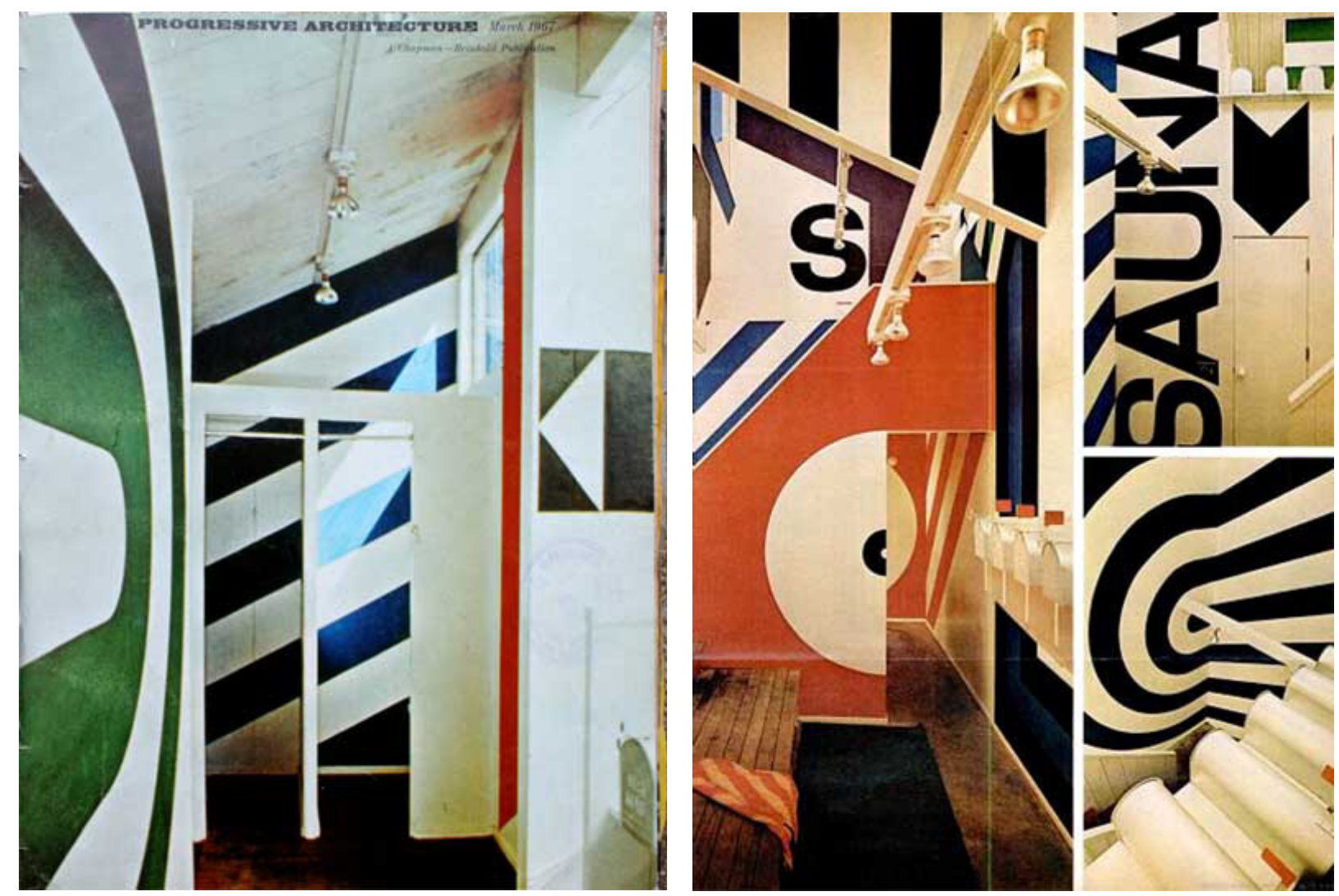

Figure 4: Barbara Stauffacher Solomon's interior supergraphics at the Sea Ranch Swim Club.

"Independent Group", at their "This Is Tomorrow" exhibition in London in November 1956. In response to this exhibit, influential architect Alison Smithson commented in a short essay: "Gropius wrote a book on grain silos, Le Corbusier one on aeroplanes, and Charlotte Perriand brought a new object to the office every morning. But today we collect ads." ${ }^{10}$ Pop art had enormous influence on architecture during the 1960s and 1970s. This is most clearly seen through the prevalence of socalled "supergraphics", which are large scale graphics applied to architectural surfaces. (Figure 4) Supergraphics were a response to the uniformity of orthodox modernism and a desire to create strong images within architecture. It does this through the literal application of pattern and typography to an otherwise repetitive order. 
The relation of so-called "Brutalist" architecture to Pop Art is less literal, but equally important. It has become clear that there were two divergent opinions on the meaning and characterization of Brutalism; that of British architects Peter and Alison Smithson and that of Reyner Banham. The Smithson's described Brutalism as, "the quest for a poetry of mass production." 11 They perceived it as an opportunity to bring the roughness and "truth" of materials back into modernism. As such, their work emphasized the material qualities and process of construction through the architectural expression. ${ }^{12}$ Architectural critic Reyner Banham held a different perspective on Brutalism which aligned more strongly with "pop" ideology; which emphasized the integration of architecture and technology. In his seminal article "The New Brutalism" (originally published in December 1955), Banham defined Brutalism as having three characteristics: "1, Memorability as an Image; 2, Clear exhibition of Structure; and 3, Valuation of Material 'as found'."13 His emphasis on image relates particularly strongly to this discussion. Banham explains: "One of the reasons for this obtrusive logic is that it contributes to the apprehensibility and coherence of the building as a visual entity,

\section{CASE STUDY: \\ "OUTSIDE THE BIG BOX" \\ ROGER SHERMAN ARCHITECTURE \& URBAN DESIGN}

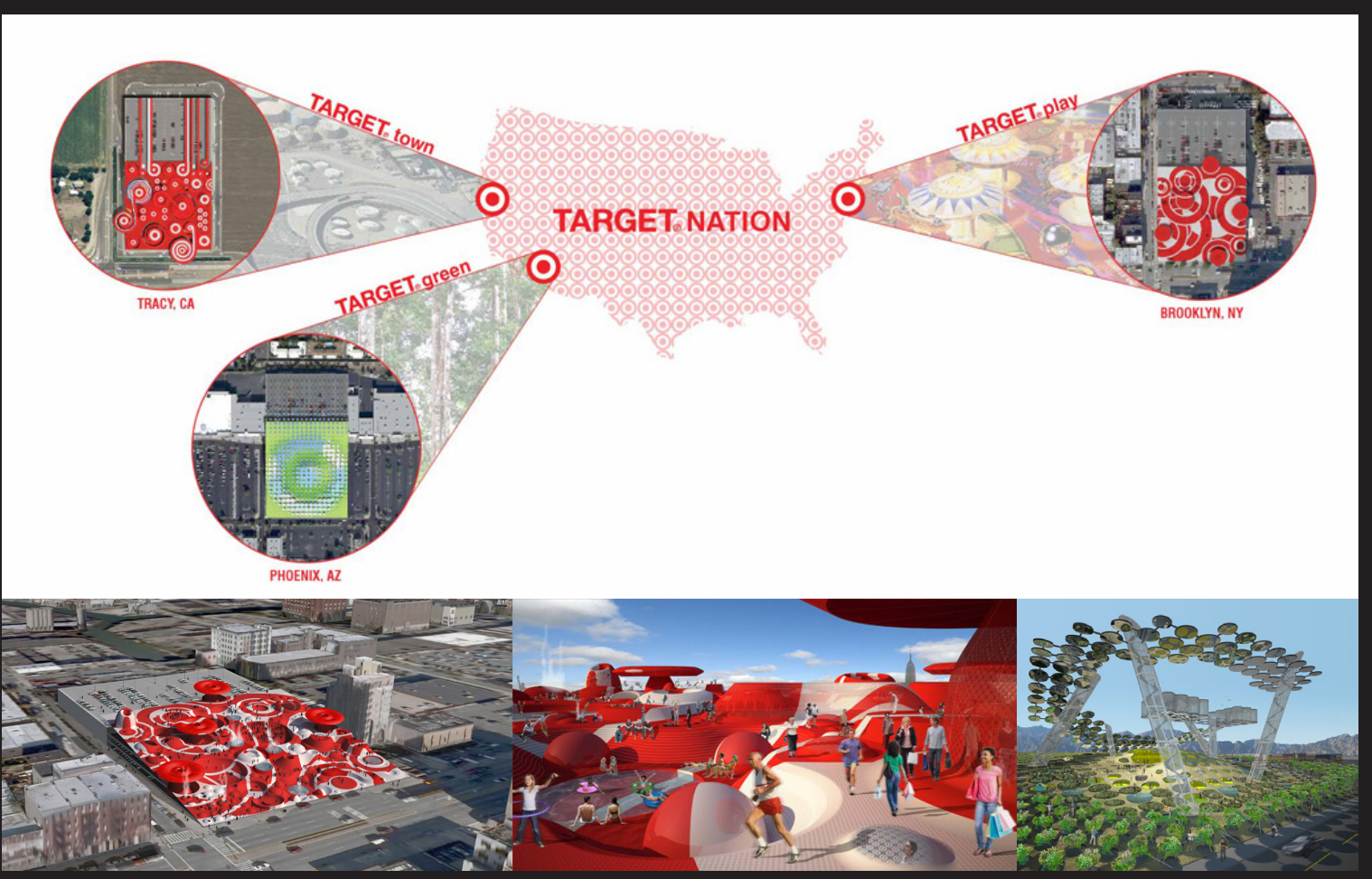

Figure 5: Images of "Outside the Big Box" by Roger Sherman Architecture \& Urban Design

The LA-Based Architect Roger Sherman took on this speculative exercise for TARGET@ which explores the function of corporate branding and consumer culture as a means of identifiability and culture. In a way, this project demonstrates a contemporary application of pop art. Today's society is just as consumerist, if not more so, than in the postwar years. We are instantly familiar with corporate branding. Here, Sherman has explored how to utilize consumer culture as means to create imageable public space and landscape. 
14 Banham, Reyner. "The New Brutalism." October 136 (2011): 24

15 George Kapelos and Christopher Armstrong. Competing Modernisms: Toronto's New City Hall and Square (Toronto: Dalhousie Architectural Press, 2015), 15

16 Eric Paul Mumford, The CIAM Discourse on Urbanism, 1928-1960 (Cambridge, Mass.: MIT Press, 2000), 175

17 George Kapelos and Christopher Armstrong. Competing Modernisms: Toronto's New City Hall and Square (Toronto: Dalhousie Architectural Press, 2015) 15

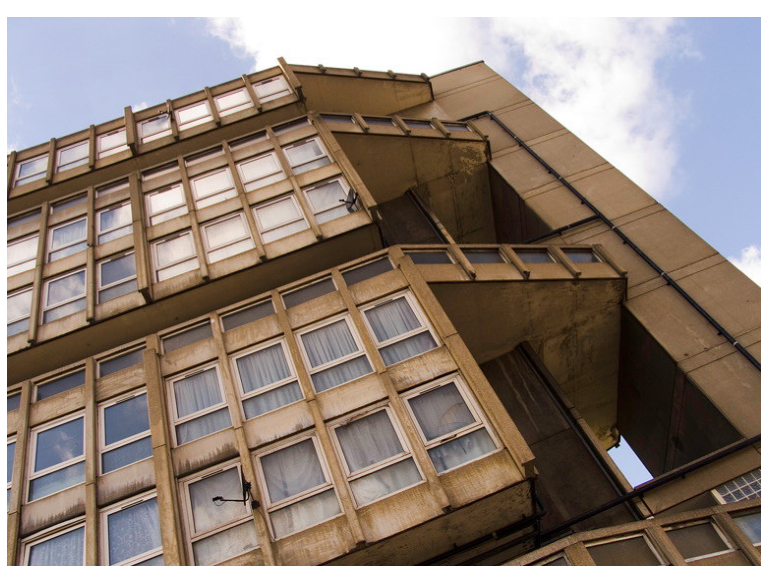

Figure 6: Robin Hood Gardens, by Peter and Alison Smithson, London, England

because it contributes to the building as 'an image. '"14 Whatever the reason for the emergence of this trend, it would seem that the overwhelming use of concrete created an opportunity for architecture to be more monumental and image-making than the dematerialized nature of the steel-andglass-dominated International Style of the 1930s. In addition to Brutalist architects' bold graphic representations, the solidity of form, use of curvilinear elements, and often massive scale suggest this intention.

The Smithson's view of Brutalism bears a strong kinship to the "New Empiricism" and "New Monumentality" movements, which entered the discourse of the Congrès international d'architecture moderne (CIAM) during their postwar conferences 6 through 8 from 1947 to 1951. New Empiricism was inspired by Scandinavian modern architecture, which demonstrated a softer approach to modernism, with more expressive forms, and a more tactile use of materials. This was intended to combat the notion that modern architecture failed to create a human experience. CIAM member Sigfried Giedion was particularly interested in the ability for architecture to capture emotion and promote human interaction. ${ }^{15}$ Scholars suggest this term was first coined by J.M. Richards, the editor of Architectural Review, who published the article "The New Empiricism: Sweden's Latest Style" in 1947. ${ }^{16}$ In Competing Modernisms: Toronto's New City Hall and Square (2015) George Kapelos explains:

"Looking to Scandinavian precedents, Richards identified the "new empiricism" in architecture - a focus on the importance of the human experience of the built world as a means of reconciling functionalism with aesthetics and human emotion. Through this paradigm, he believed modernism could be appreciated as much through emotional experience as from aesthetic or pragmatic perspectives. "17

This theme was evident in the conference program of CIAM 6 (1947) through the 


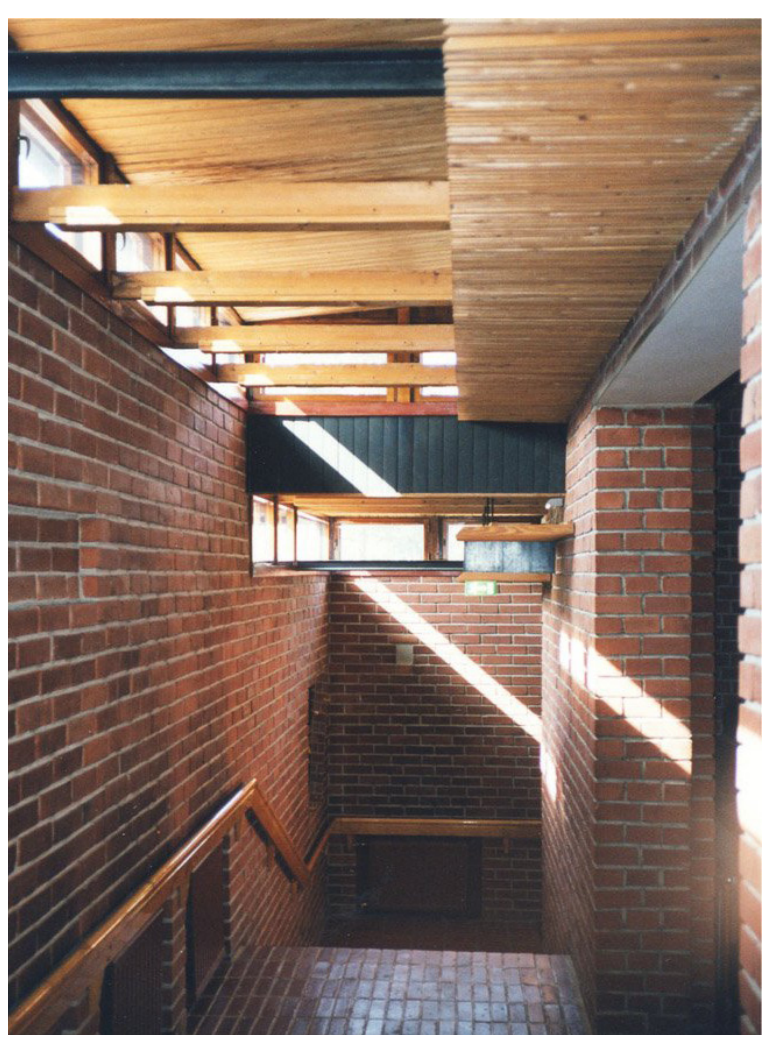

Figure 7: Saynatsalo Town Hall, by Alvar Aalto, at Saynatsalo, Finland, 1949 competition, built 1952.

inclusion of a session entitled "Architectural Expression". ${ }^{18}$ Later, The influence of "new empiricism" could be seen very clearly in the work of American architect Louis Kahn, who was heavily influenced by the work of Finnish architect Alvar Aalto (among others). (Figure 7 and 8)

The "New Monumentality" movement suggested that architecture

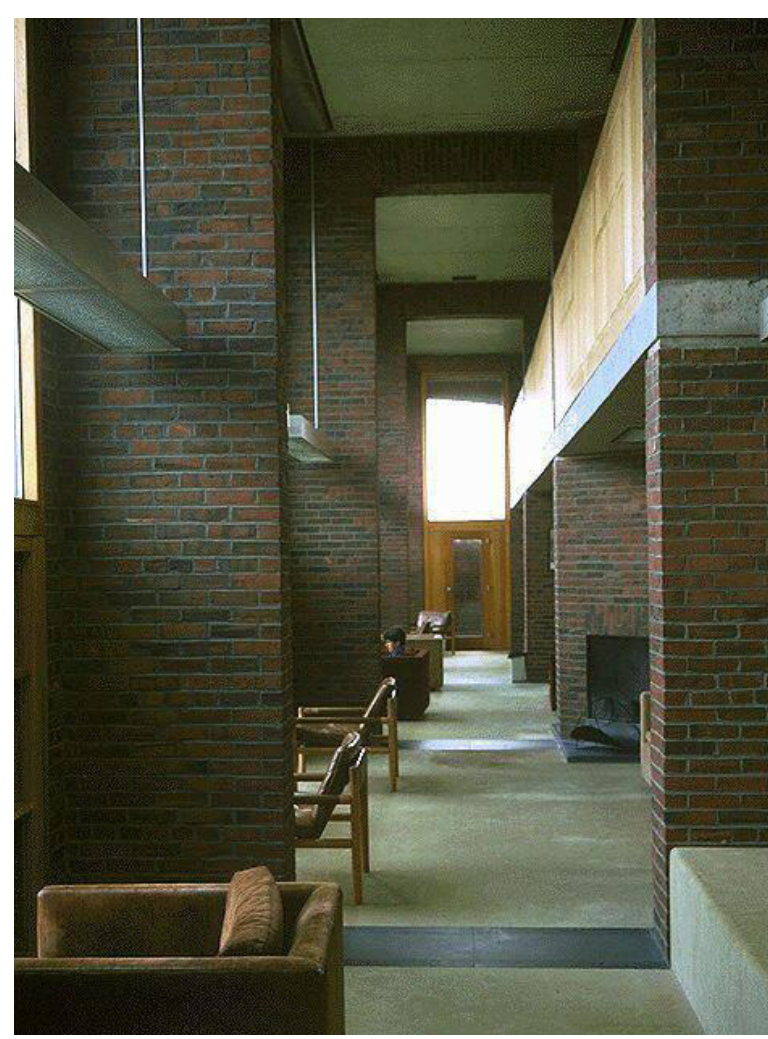

18 Eric Paul Mumford, The CIAM Discourse on Urbanism, 1928-1960 (Cambridge, Mass.: MIT Press, 2000), 175

$19 \mathrm{lbid}, 150$
Figure 8: Exeter Library, by Louis I. Kahn, at Exeter, New Hampshire, USA,1967 to 1972.

needed to serve more than just function, but be a civic symbol and image for the general public. This initiative began with Le Corbusier and then CIAM members Sigfried Giedion and Josep Lluis Sert. ${ }^{19}$ The "new monumentality" sought to prove that modern architectural expression could be monumental, contrary to the belief of critics like Lewis Mumford who said, "The very notion of a modern monument is a 
20 Eric Paul Mumford, The CIAM Discourse on Urbanism, 1928-1960 (Cambridge, Mass.: MIT Press, 2000), 150

21 Volker M. Welter, "From Locus Genii to the Heart of the City: Embracing the Spirit of the City." In Modernism and the Spirit of the City, ed. lain Boyd Whyte (London: Routledge, Taylor \& Francis Group 2003), 46

22 Eric Paul Mumford, The CIAM Discourse on Urbanism, 1928-1960 (Cambridge, Mass.: MIT Press, 2000), 150

23 Simon Sadler, Archigram: Architecture without Architects (Cambridge, MA: MIT Press, 2005), 5

\section{4 lbid}

$25 \mathrm{lbid}, 6$

26 Ibid, 11 contradiction in terms: if it is a monument, it cannot be modern, and if it is modern it cannot be a monument." 20 Giedion and Sert drafted the 'Nine Points on Monumentality' in 1943. In "From Locus genii to the heart of the city: embracing the spirit of the city" Volker M. Welter explains the intention of this work:

"the manifesto describes monuments as a link between past and future, identifies as the most vital monuments those which 'represent the spirit of the collective feeling of modern times', and, finally, names the creation of monuments as the climax of the project of modern architecture. "21

This movement was not intended to revive classicism but to open a discussion about expression and monumentality within modernism. ${ }^{22}$ By the 1950s, even Le Corbusier, the architect who had once championed orthodox modernism, was creating monumental structures. (Figure 9)

In contrast to the Smithsons and the postwar CIAM emphasis on human emotion and sensory experience, Banham's view of Brutalism focused more on imagery through the integration with technology. The legacy of this school of thought seems to have persisted through the work of Archigram and later "High Tech" architecture.
Archigram was a group of young British architects who began producing an independent publication full of spectacular architectural representations in the 1960s. Archigram's work was intentionally speculative, and focused on graphic representation. In the spirit of Pop Art the image was most important. Archigram attempted to align modernism with the technological focus characterized by early modernism, with its notions of architecture as a 'machine for living in' as coined by Le Corbusier. Through their explorations, they investigated the compatibility of postwar technologies and industries like electronics and pneumatics. ${ }^{23}$ In Archigram: Architecture without Architects (2005), Simon Sadler suggests that: "Archigram was a reminder that modernism had lost its technological nerve." 24 Archigram's work shows a desire to create imageability out of current technology rather than a return to premodern 'tradition'. 25 They insisted that imagery could be created out of an embrace of all that is new. ${ }^{26}$

While Archigram never built any completed projects, this approach later materialized in the movement of High Tech architecture. In "High-Tech: Modernism Redux", Sarah Deyong explains, 


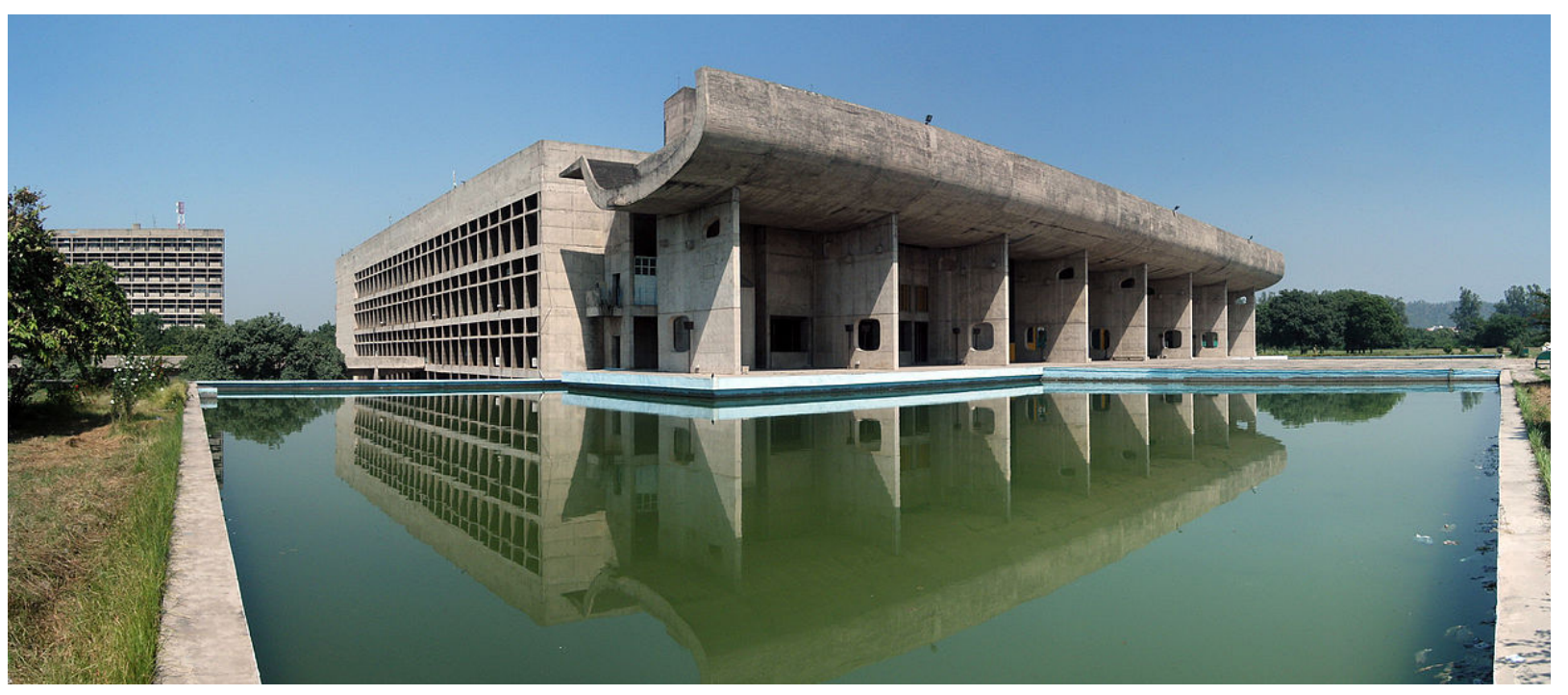

Figure 9: Palace of Assembly, by Le Corbusier, at Chandigarh, India, completed in 1963

"While Archigram brought a refreshing dose of fun to the concrete buildings being built at the time, High Tech turned its ultramodern imagery into a built reality. "27

High Tech architecture found its highest representation in Richard Rogers and Renzo Piano's Pompidou Centre in Paris. This museum showcases and exaggerates both its structure and systems, by relocating these elements to the outside of the envelope. It has been suggested that the Pompidou Centre could be seen as the realworld manifestation of Archigram's PlugIn City proposal. ${ }^{28}$ Here the recognizable "imagery" is derived from the building's inherent modernity.

While Archigram and high-tech architects embraced technology and newness, not everyone agreed that this was the best way to approach 'pop' or populist architecture. Most notably Venturi and Scott Brown campaigned for imageability through references to historic architecture. Simon Sadler explains:

"For Scott Brown, and her collaborator from 1960, Robert Venturi, a truly "popular" architecture required not Archigram's perpetual change of super-technological consumerism, but a "homecoming," a new interest in meaning and legibility, a new vernacular. "29
27 Sarah Deyong, "High-Tech: Modernism Redux" in A Critical History of Contemporary Architecture 1960 -2010, ed. Elie Haddad, David Rifkind, and Peter L. Laurence (Ashgate Publishing Group, 2014), 52

\section{8 lbid, 52-53}

29 Simon Sadler, Archigram: Architecture without Architects (Cambridge, MA: MIT Press, 2005), 45 


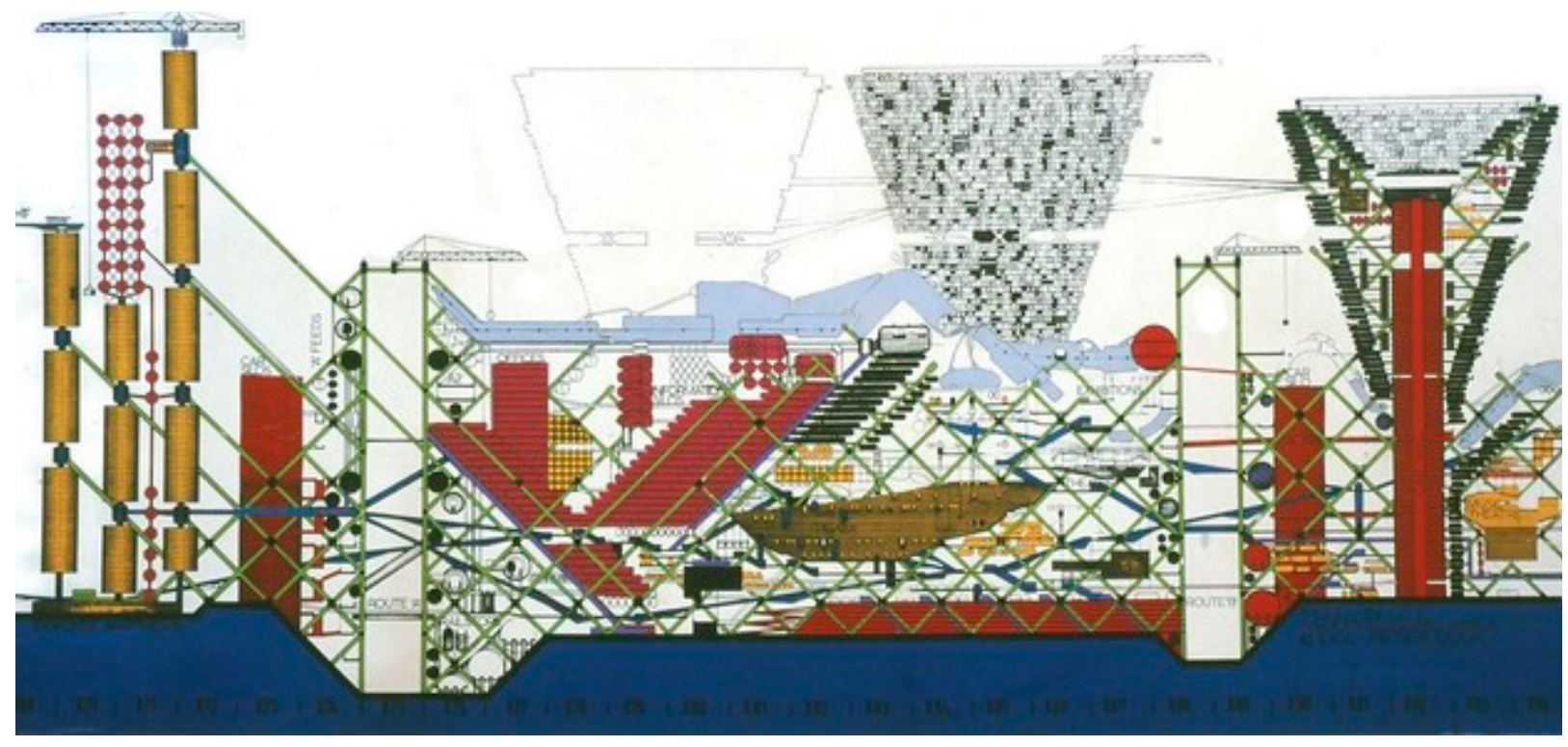

Figure 10: "The Plug-In City" by Archigram,1964

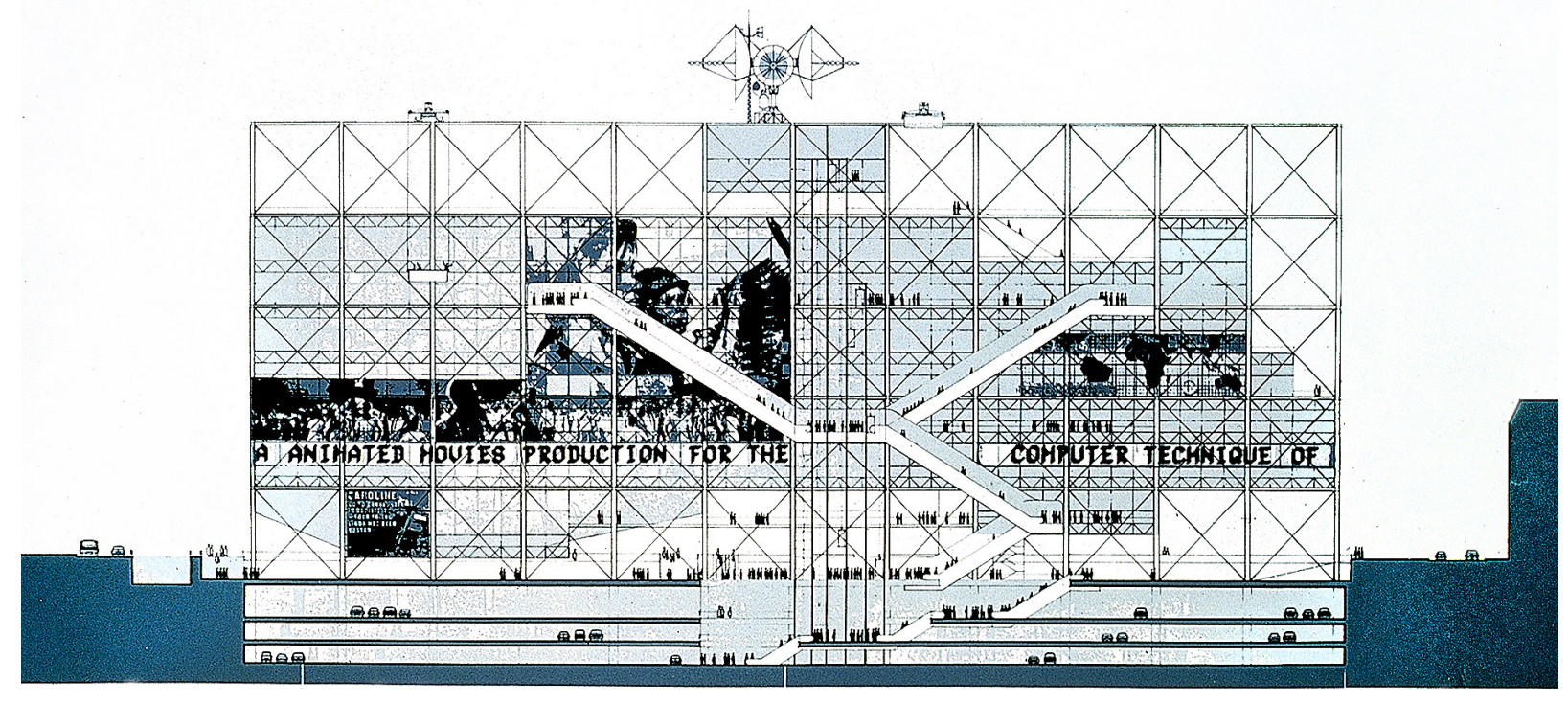

Figure 11: Competition Drawing for Centre Pompidou, by Richard Rogers and Renzo Piano, 1977
This 'historicist' approach towards imagemaking grew increasingly popular, and became the predominant language of postmodern architecture. By the late 1970 s and early 80 s, The campaign against modernism had picked up too much momentum, and interest in the evolution of modernism (in North America and Britain at least) had quickly waned.

This chapter demonstrates that a critical response to uniformity in orthodox modernism emerged in the postwar period, far before full-blown postmodern thought had emerged. Clearly, the decades following WWII were characterized by a rich and multi-layered discourse on imageability and monumentality in architecture.

Inherent in this discussion is the idea that imagery can come from innovation, and through an expression of the current time. This aspiration can be adopted within a contemporary response.

The modernist environments that these scholars and architects were critiquing have not radically changed in nature. Although the "The Athens Charter" was developed by CIAM in the 1930s, periods of economic depression and the Second World War delayed the widespread 


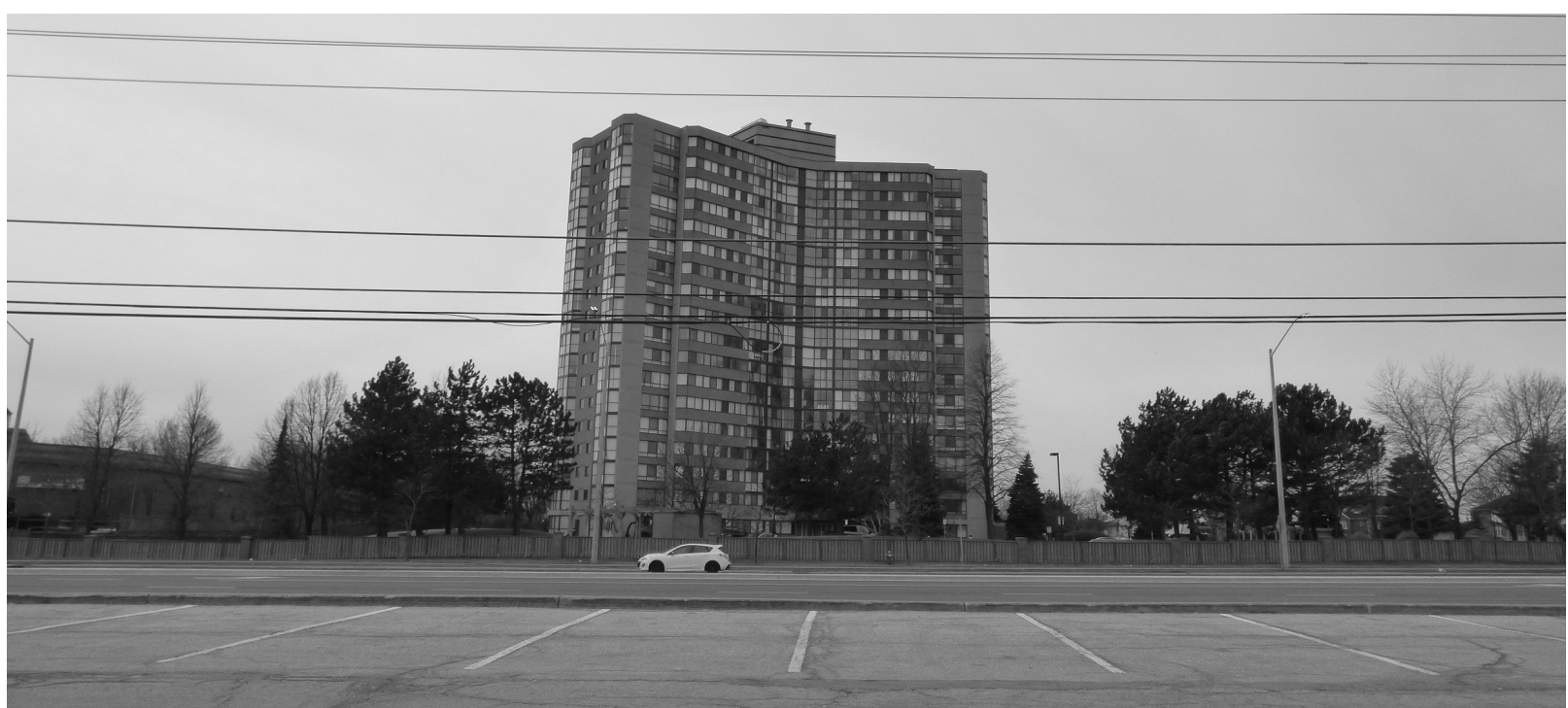

Figure 12: Modernist residential tower on Dixie Rd. (as seen from the Rockwood Mall parking lot)

application of orthodox modernism. After

the war, an overwhelming embrace of

modernism was driven by a need for rapid reconstruction and development. Andrew Higgot elaborates:

"Cities all over the world transformed themselves with buildings derived from prototypes created in the vanguard of modernist vision. In a sense, although not quite literally, one is talking about architecture without architects: modernist practices and modernist forms moved out of the experiment of prewar radicals and into the policies and programs of large city authorities. ${ }^{\prime 30}$

Due to the speed and scale of this development, orthodox modernism
30 Andrew Higgot, "Building the Modern City," in The Modern City Revisited, ed. Thomas Dekke (London: Spon, 2000), 151 became highly commercialized, and no longer critical of itself. It is out of this commercialized modernism that North America's postwar suburbs were created. The forces of mass production led to repetitive single-family homes, big-box stores, strip malls, and isolated modernist towers. These characteristics continue to dominate suburban landscapes. Thus, a lack of imageability continues as a huge source of criticism against suburban environments. This discourse provides a foundation for the discussion of this thesis. These ideas led directly into post-modern thought, and later through a more recent reaction to modernism, in the form of supermodernism. (discussed in Chapter 5.2) 
1 The Modern City Revisited (London: Spon, 2000), 2

2 Volker M. Welter, "From Locus Genii to the Heart of the City: Embracing the Spirit of the City." In

Modernism and the Spirit of the City, ed. lain Boyd Whyte (London: Routledge, Taylor \& Francis Group, 2003), 36

3 George Kapelos and Christopher Armstrong. Competing Modernisms: Toronto's New City Hall and Square (Toronto: Dalhousie Architectural Press, 2015), 14

\section{CHAPTER 2.3 CRITIQUE OF URBAN SPACE}

In addition to the visual uniformity of orthodox modernist architecture, there has been much criticism towards the urban structure of modernist planning, mainly its orientation towards the automobile rather than pedestrians. Almost immediately after WWII, a discussion on the evolution of modernism to support better urban spaces was in full force. It is important to remember that prewar modern planning models were a response to the poor quality of life in industrial cities. Strategies focused on creating better living conditions through indoor plumbing, electricity, mobility, separation from industry, and centered on the delivery of housing. Often referred to as 'functionalism' or 'the functional city', this theory was defined by the CIAM's "Athens Charter" (1933). This model was highly influential in the postwar period, as these scientific approaches were seen as an economical solution to the housing demand and rapid reconstruction of cities. However due to the overwhelming focus on housing within this model, there was a lack of concern for the public realm.

CIAM's Athens Charter established four essential classifications: dwelling, work, leisure, and circulation. It did not include civic space. ${ }^{1}$ Thus, the urban renewal schemes based on Le Corbusier's "tower in the park model" were very quickly seen as failures because new housing with better services did not fix social problems as they had hoped. By the time this form of modern planning (characterized by separation of uses, auto-centric planning, repetitive and banal architecture) had met widespread appeal, the modern architects who had developed it were already re-evaluating it. Most critically, the missing principle of civic space was coming into focus.

As discussed earlier, the CIAM congresses 6 through 8 (1947 - 1951) represented "a self-reflective interrogative process," where members reevaluated the early principles of their discipline and began a discourse on humanism in architecture. ${ }^{2}$ During these years, the CIAM was turning its attention to emerging themes of $\mathrm{New}$ Monumentality, New Empiricism, and the importance of civic public spaces. ${ }^{3}$ All of these themes indicated a growing desire for image-making (as discussed in the previous chapter), but also an interest in designing for human scale and human interaction, which would lead to better urbanism. The 
New Monumentality movement explored how modern architecture could create monumental imagery, but also how it could enrich and support civic spaces. In his article "The Human Scale in City Planning," (1944) Jose Luis Sert linked the ideas of New Monumentality to urbanism. In this piece, he advocated for pedestrian-oriented civic centres designed for "human values" and neighbourhood dynamics; stating:

"the civic and cultural center constitutes the most important element... its brain and governing machine," and in it should be found university buildings, museums, concert halls and theatres, a stadium, the central public library, administration buildings, "and areas especially planned for public gatherings, the main monuments constituting landmarks in the region, and symbols of popular aspirations. "

This emphasis on civic cores was the focus of CIAM 8 (1951), which was entitled "The Heart of the City."

CIAM 8 is often regarded as one of the most important congresses in CIAM's history, because it marked a huge shift in thinking. In The CIAM Discourse on Urbanism 1928-1960 (2000), Eric Mumford explains:

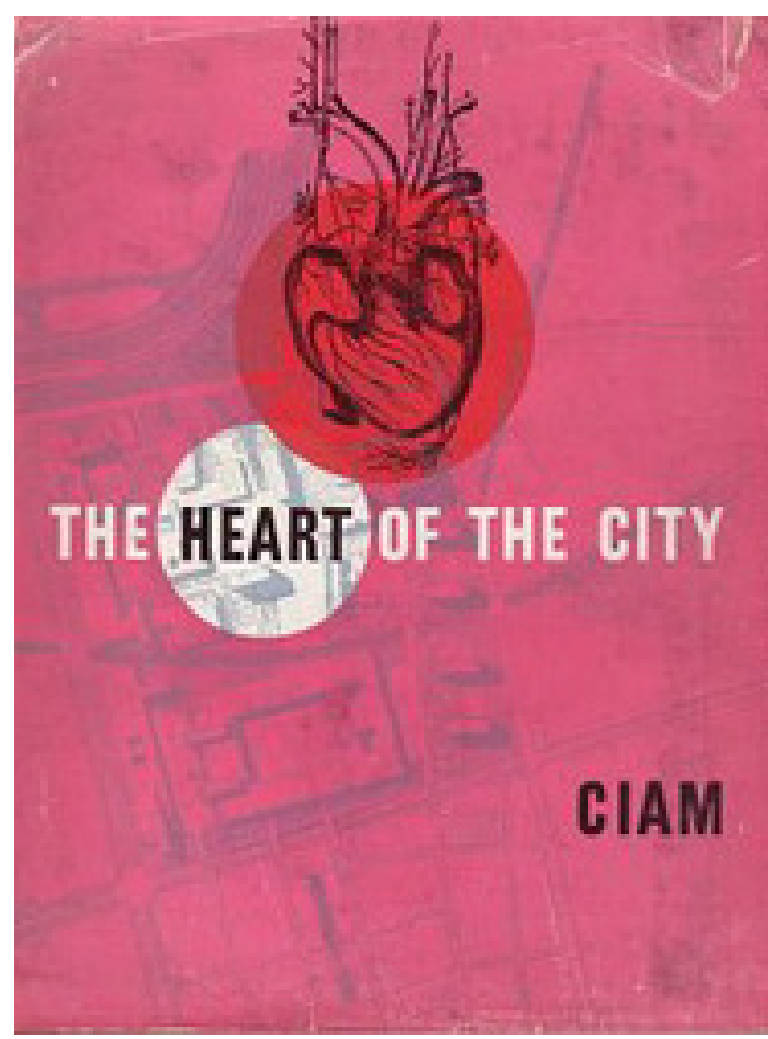

4 Eric Paul Mumford, The CIAM Discourse on Urbanism, 1928-1960 (Cambridge, Mass.: MIT Press, 2000), 151-152

5 lbid, 215

Figure 1: Cover of CIAM's The Heart of the City

Towards the Humanisation of Urban Life (1952).

"the "Heart of the City" Congress was the most significant of postwar congresses, one of the earliest efforts to discuss the issue of urban public space in the transformed circumstances of modern architecture after the war... CIAM 8 can be seen as a reference point for the new forms of public space, including shopping malls, renewed downtowns, and theme parks, that came to characterize urbanism in the rapidly decentralizing cities of the 1950s and later." 
6 For more on the influence of CIAM principles on the Toronto City Hall competition, see George Kapelos and Christorpher Arcmstrong's Competing Modernisms: Toronto's New City Hall and Square (2015).

7 Smiley, David, "Suburban Rhetorics: Planning and Design for American Shopping, 1930-1960." In Making Suburbia: New Histories of Everyday America, ed. John Archer, Paul J. P. Sandul, and Katherine Solomonson (Minneapolis: University of Minnesota Press, 2015), 155

8 Reyner Banham, Megastructure: Urban Futures of the Recent past (New York: Harper and Row, 1976), 10

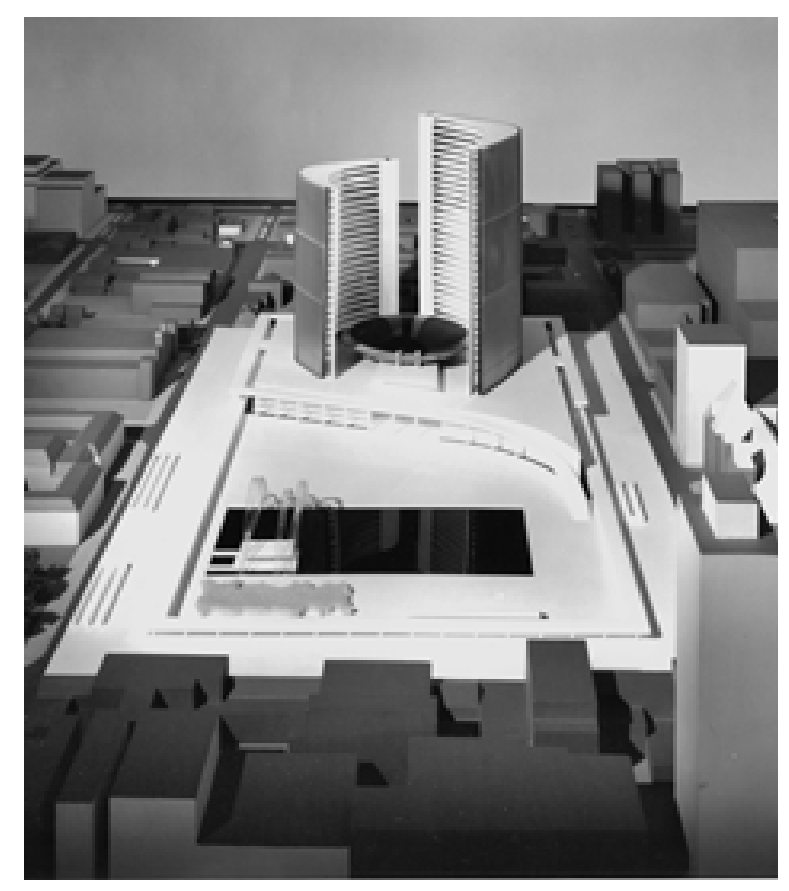

Figure 2: Viljo Revell's winning entry to the 1958 Toronto City Hall and Square competition.

The influence of "The Heart of the City" conference is highly evident in the designs for the 1958 Toronto City Hall and Square Competition, which promoted an objective to create a civic monument as well as important public space. ${ }^{6}$ This influence was not only applicable to civic buildings like city halls, but to public institutions like shopping malls. It is no coincidence that Victor Gruen's 1964 manifesto is entitled "The Heart of Our Cities". The title is a direct reference to the discussions of CIAM 8. As discussed in Chapter 1.2, for Gruen, the shopping mall was intended as a megastructure which would act as an urban core. ${ }^{7}$ Gruen sought to translate qualities of urban space into a self contained volume. Similarly, the "New Town Program" in England also shared this thinking, imagining that megastructures could serve as the central cores of new developments. Thus, the "megastructure" concept was thought to be the ultimate synthesis of the "core" concept; it integrated urbanism and architecture within one comprehensive volume.

In 1976, architectural critic Reyner Banham produced a comprehensive volume on the phenomenon of the megastructure. In Megastructure: Urban Futures of the Recent Past (1976), Banham is simultaneously fascinated and critical of the ideas. He suggests possible reasons for its short-lived appeal, stating:

"...it offered to make sense of an architecturally incomprehensible condition in the world's cities, to resolve the conflicts between design and spontaneity, the large and the small, the permanent and the transient... but its downfall was that these projects took so long to build that they were out of fashion by the time they were complete. ${ }^{\prime 8}$ 


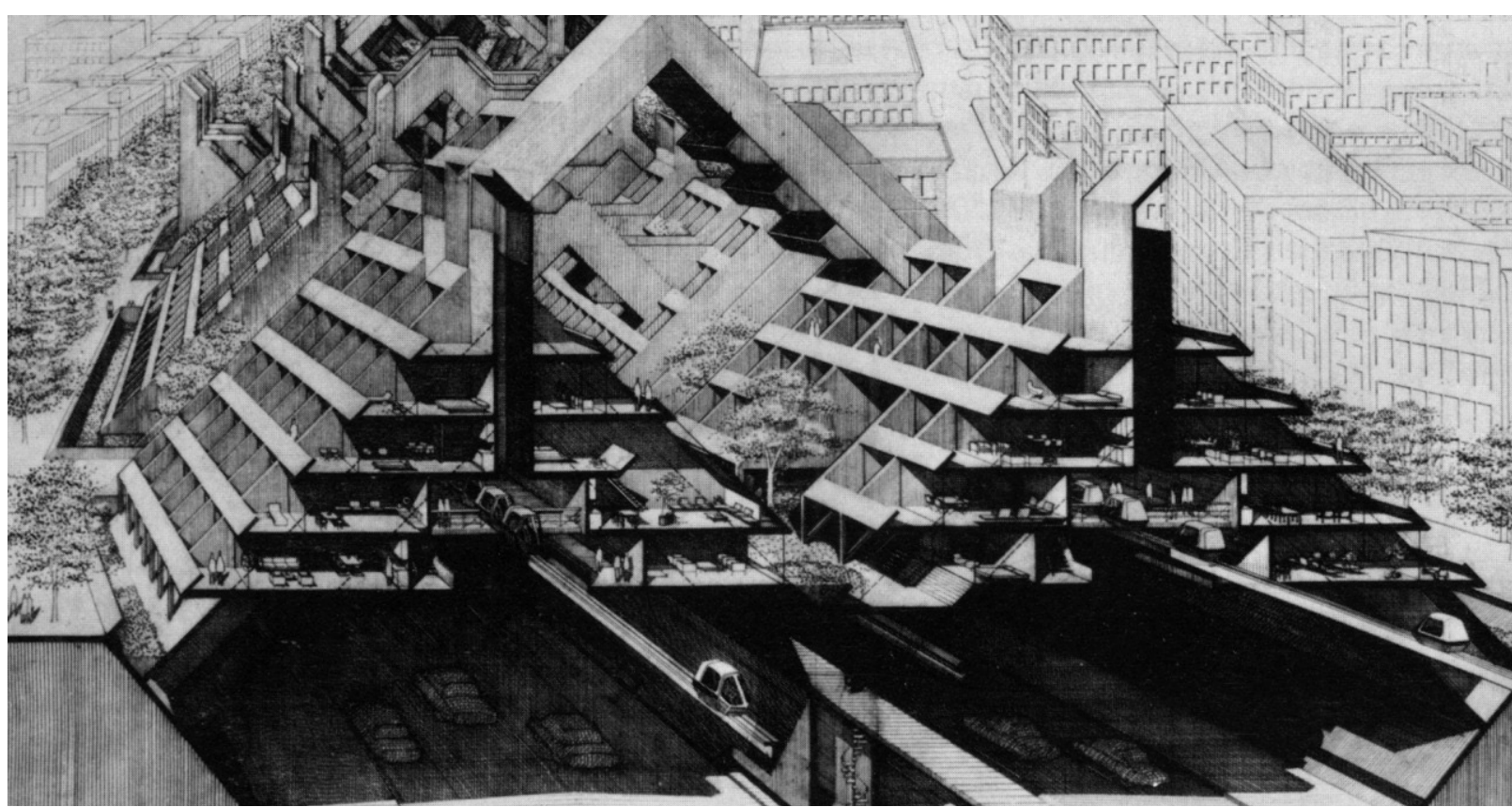

Figure 3: Conceptual Section drawing for Paul Rudolph's 1970 (unbuilt) Lower Manhattan Expressway project; one of the most radical proposals during the megastucture's heydey.

It seems that the issues with megastructures paralleled general criticisms of modernism; that it was highly monotonous, non-

hierarchical, and did not engage the public realm. In an effort to create a successful interior public realm, it had often neglected the street. Banham argues that any large scale vision by a single person tends to be problematic:

"Some time around 1968 it seems to have been perceived that a city or a large part of a city designed by one man, or by any group unified enough to produce a comprehensive design, would be a parlously thin, starved and impoverished environment, both visually and in larger, less precise cultural terms." ${ }^{19}$

\section{Following this trend towards} rationalized design for urban space, the advocated for not only single monuments and single "cores", but also to integrate this thinking more broadly in to planning for new developments. They supported the development of an urbanism which was more flexible, human scaled, less universalized, and more focused on younger CIAM members increasingly
9 Reyner Banham, Megastructure: Urban Futures of the Recent past (New York: Harper and Row, 1976), 216 
10 Annie Pedret, Team 10: An Archival History (London: Routledge Taylor \& Francis Group, 2013), 4

\section{Ibid, 1}

12 Tom Avermaete, Another Modern: The Post-war Architecture and Urbanism of Candilis-Josic-Woods (Rotterdam: NAi, 2005), 51

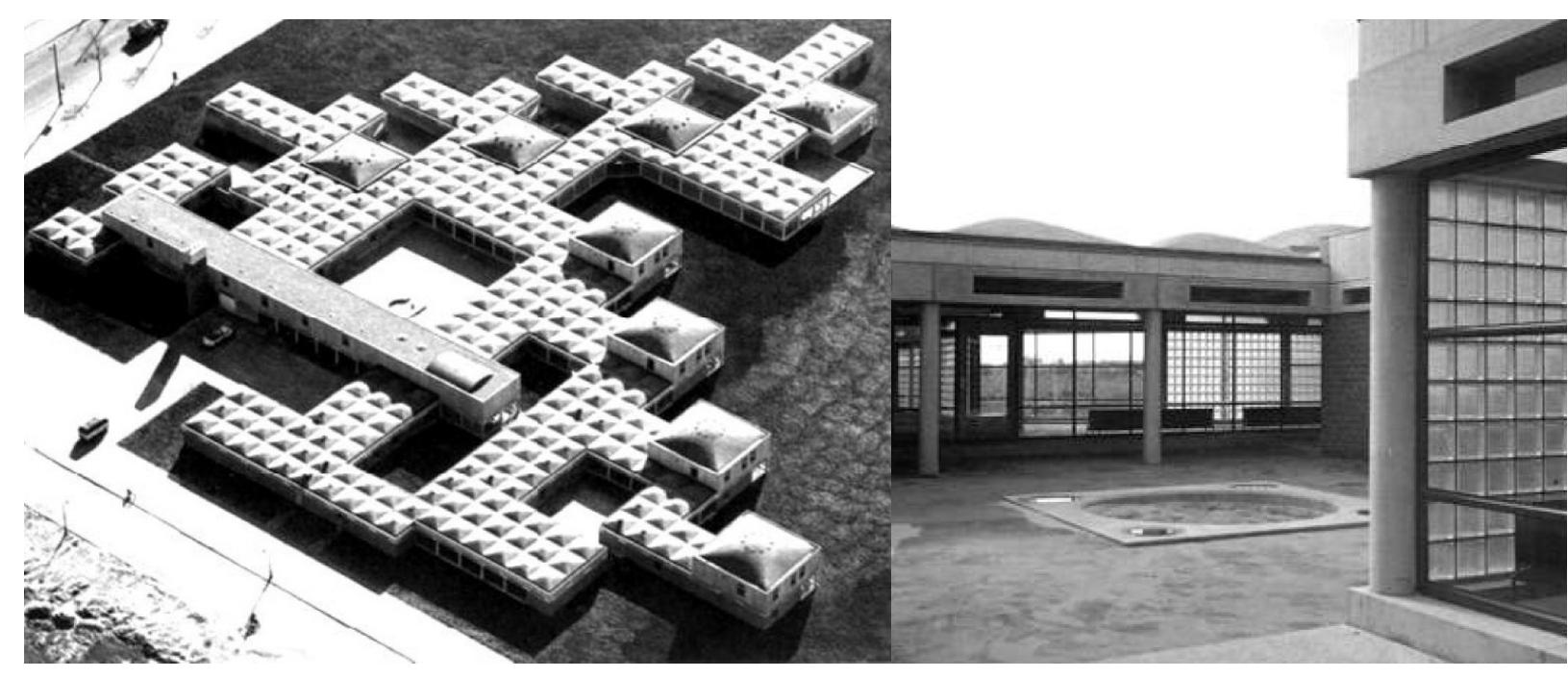

Figure 4 \& 5: Amsterdam Orphanage, by Aldo Van Eyck, 1960

creating more successful social conditions. ${ }^{10}$

This group of primarily Dutch and British architects began meeting separately from CIAM in 1954. They eventually 'succeeded' CIAM after CIAM 10, after which they became known as Team 10. The most prominent members of this group were "Dutch architects Jacob B. Bakema and Aldo van Eyck, Greek-born architect Georges Candilis, American architect and urban planner Shadrach Woods, and British husband-and-wife team Peter and Alison Smithson." "11 Team 10 became widely known for their development of mat urbanism, a strategy which uses repetitive modular systems to create low-density urbanism. In Another Modern: The Post-War Architecture and Urbanism of Candilis-Josic-
Woods (2005), Tom Avermaete explains:

"Identity, association and neighbourliness were thought to replace the 1920s concerns with biological needs and material norms, the four categories placed on the program for the tenth congress in Dubrovnik were: mobility, cluster, growth and change, and urbanism and habitat."12

In response to this group's criticism that functionalist modernism was too rigid, the intention of mat urbanism was that repetitive modules (Figure 4 and 5) or clusters (Figure 6) could be added on continually as needed. This method hoped to replicate similar incremental growth patterns to those of traditional North 
African casbahs. ${ }^{13}$ In reality, the repetitive dimensions of the modules negated any unplanned quality, as it would only support the pre-determined characteristics of the system. The ability to add on to the mat as needed was never demonstrated, because so few mat buildings were actually built, and the approach quickly fell out of favour. Ultimately, the system was incredibly difficult to configure for an existing urban fabric, and did not allow for variation of development. While this system was intentionally anti-monumental, anti-figural and anti-hierarchical, this was in opposition to emerging discussions of image and monumentality (discussed in the previous chapter). Thus, mat buildings struggled with the same issues of imageability that earlier models of modernism had.

From a contemporary perspective, the repetitive, monotonous nature of mat urbanism does not sufficiently improve upon the issues of orthodox modernism. As realized through my own design research (see page 53), contemporary society is far to complex and varied to suit a continuous 'mat' solution. However, as explored further in Chapter 5.3, the megastructure concept has remained relevant in contemporary architecture. More recent incarnations have

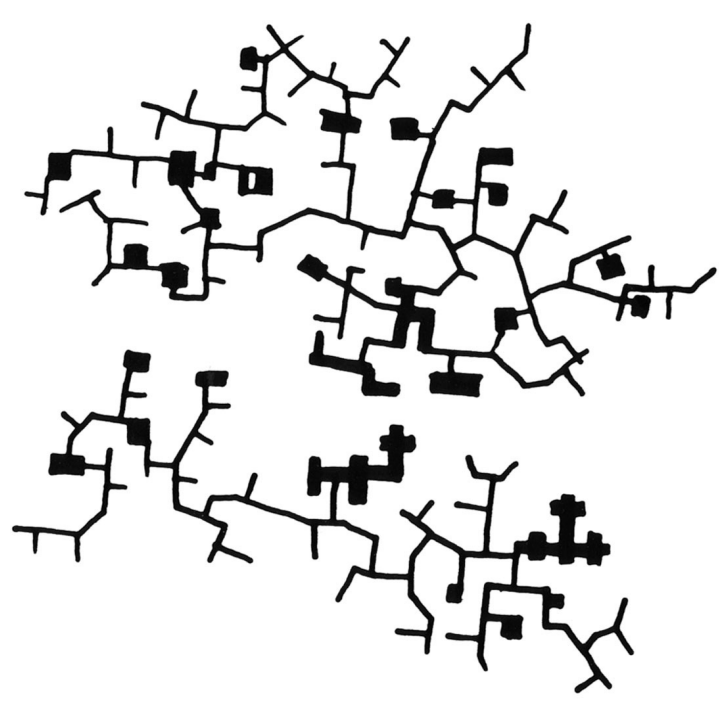

13 Frances Hsu, "Dutch Modern Architecture: from an Architecture of Consensus to the Culture of Congestion" in A Critical History of Contemporary Architecture 1960 -2010, ed. Elie Haddad, David Rifkind, and Peter L. Laurence (Ashgate Publishing Group, 2014), 209
Figure 6: Diagram of "Cluster City" concept. (195253) Alison and Peter Smithson

been more mindful of scale, permeability and visual variety.

\section{Ultimately, there are valuable} lessons to learn from these discussions and explorations. Within this discourse was a desire to produce a more desirable urban condition through architecture. These strategies did not reject the scale and complexity of modern development, but saw it as an opportunity. This somewhat 'utopian' attitude is worth pursuing with regards to transforming suburban places. In his essay "The Modern City Revisited," Allen Cunningham suggests: 
14 Allen Cunningham, "The Modern City Revisited" In The Modern City Revisited, ed. Thomas Deckker (London: Spon, 2000), 247
"In the evolution of architecture and urbanism, the twentieth-century Modern Movement is unique for inventing ideas that the future could be 'designed,' and that the promise anticipated spiritually and physically improving conditions over those inherited. The optimism generated by this extraordinary intellectual and technical revolution has been frustrated by events beyond the control of designers unable to harness the forces which shape our environment." 14

For the most part, this optimism towards designing new places has waned. While Postmodern and New Urbanist theory suggests that non-traditional architecture and planning cannot result in successful urbanism, contemporary architects can return to the challenge of consciously designing modern places. 


\section{DESIGN RESEARCH: EXPERIMENTATION WITH MEGASTRUCTURE \& MAT URBANISM}

EARLIER INVESTIGATION FOR ROCKWOOD MALL REDEVELOPMENT BY AUTHOR

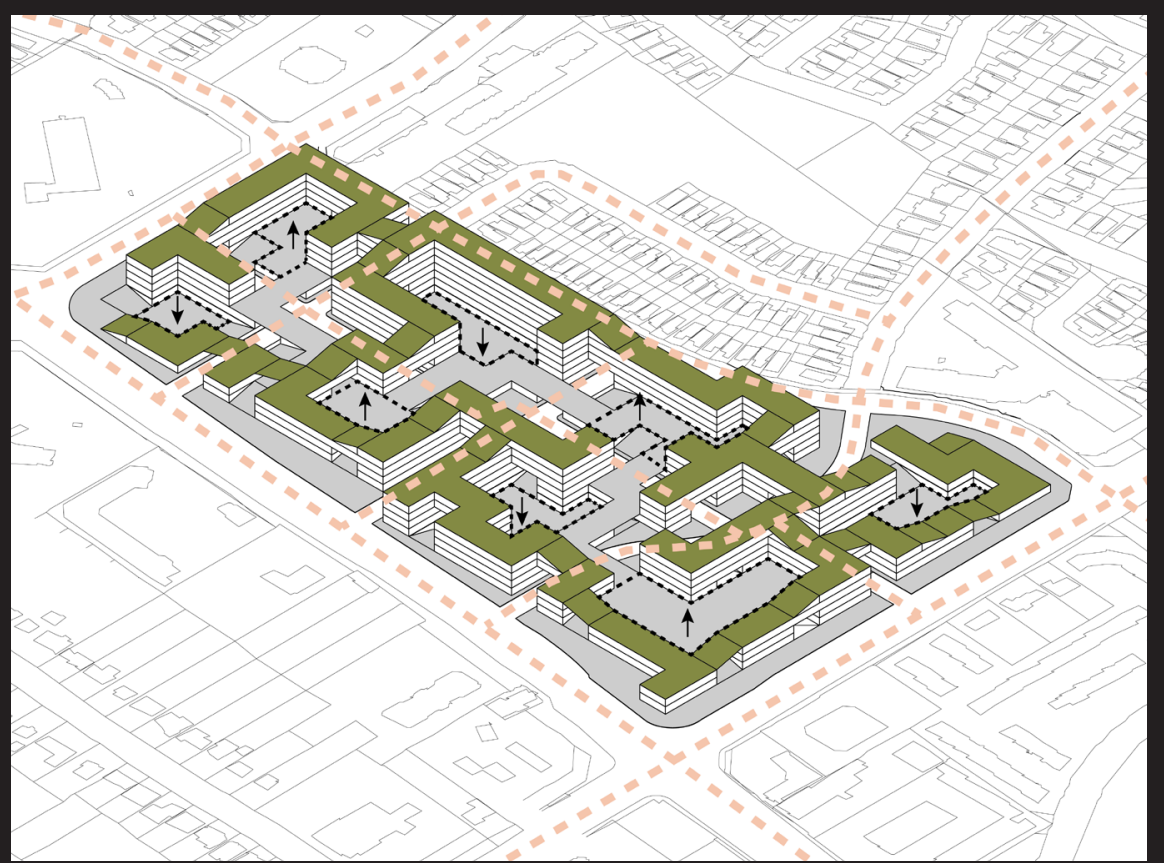

The thesis research included an investigation of a modular 'mat' strategy for the selected Rockwood Mall site. The scheme attempted to create a network of interconnected open spaces, but soften the 'megastructure' concept by having it appear as separate blocks above grade. In this proposal, each block is defined by a central open public space, while existing as part of a single network. As well, the roof surfaces were designated as productive landscapes.

This investigation revealed that the non-hierarchical nature of the repetitive module was at odds with the desire to create identifiable architectural forms and spaces. The system does not adequately support a variety of urban experiences. In order to provide a sense of hierarchy, there must be some separation and

Figure 7 (above): Axonometric view of earlier proposal Figures 8 \& 9 (below): Photos of earlier design model

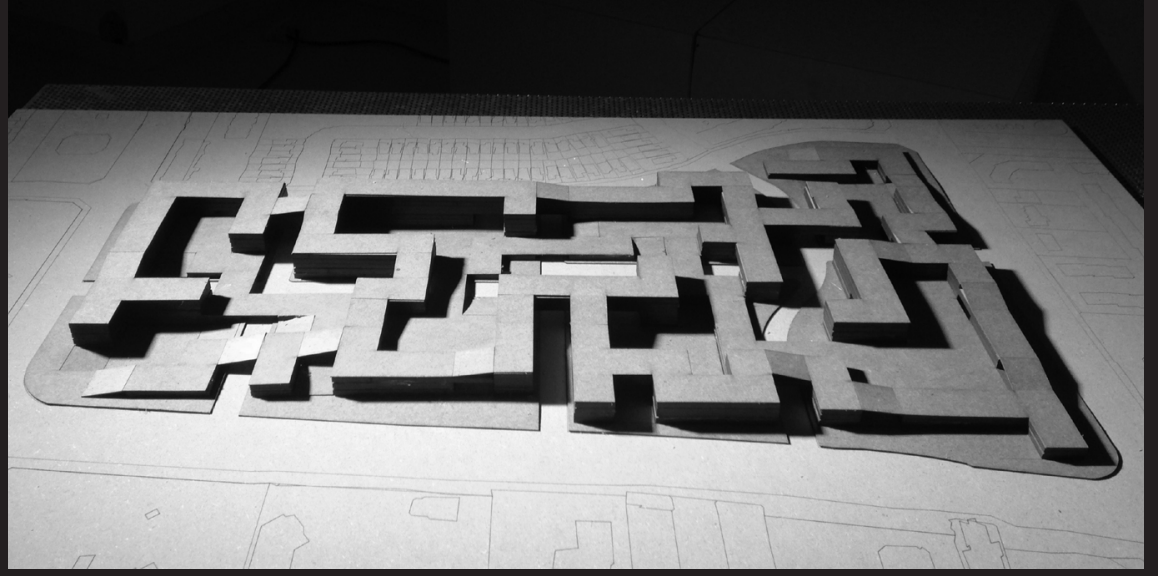
contrast between volumes.

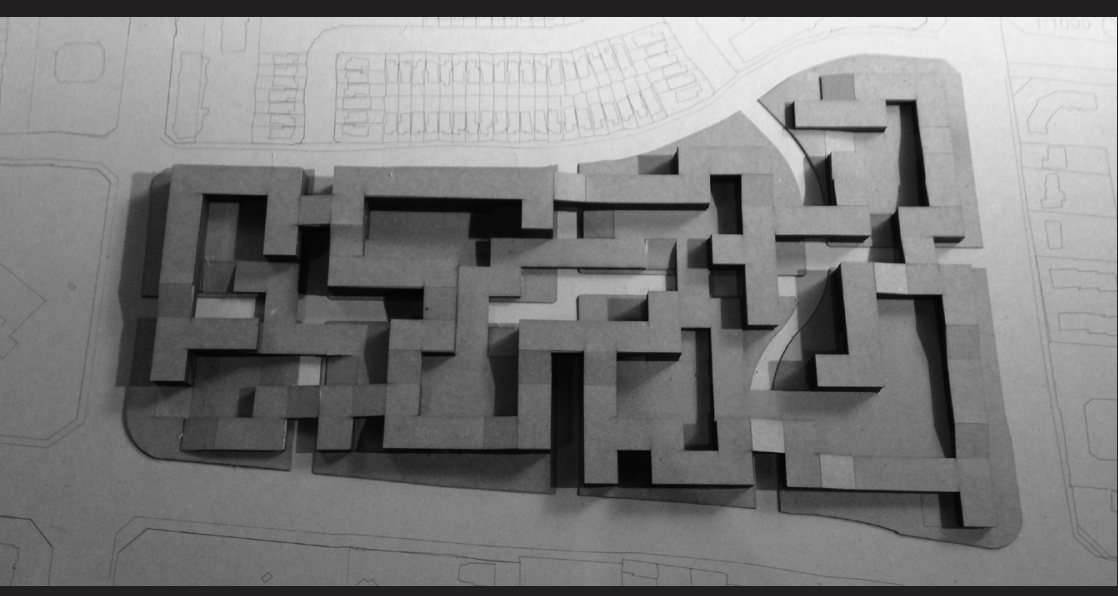




\section{PART 3: RECENT ATTEMPTS TO TRANSFORM SUBURBIA}

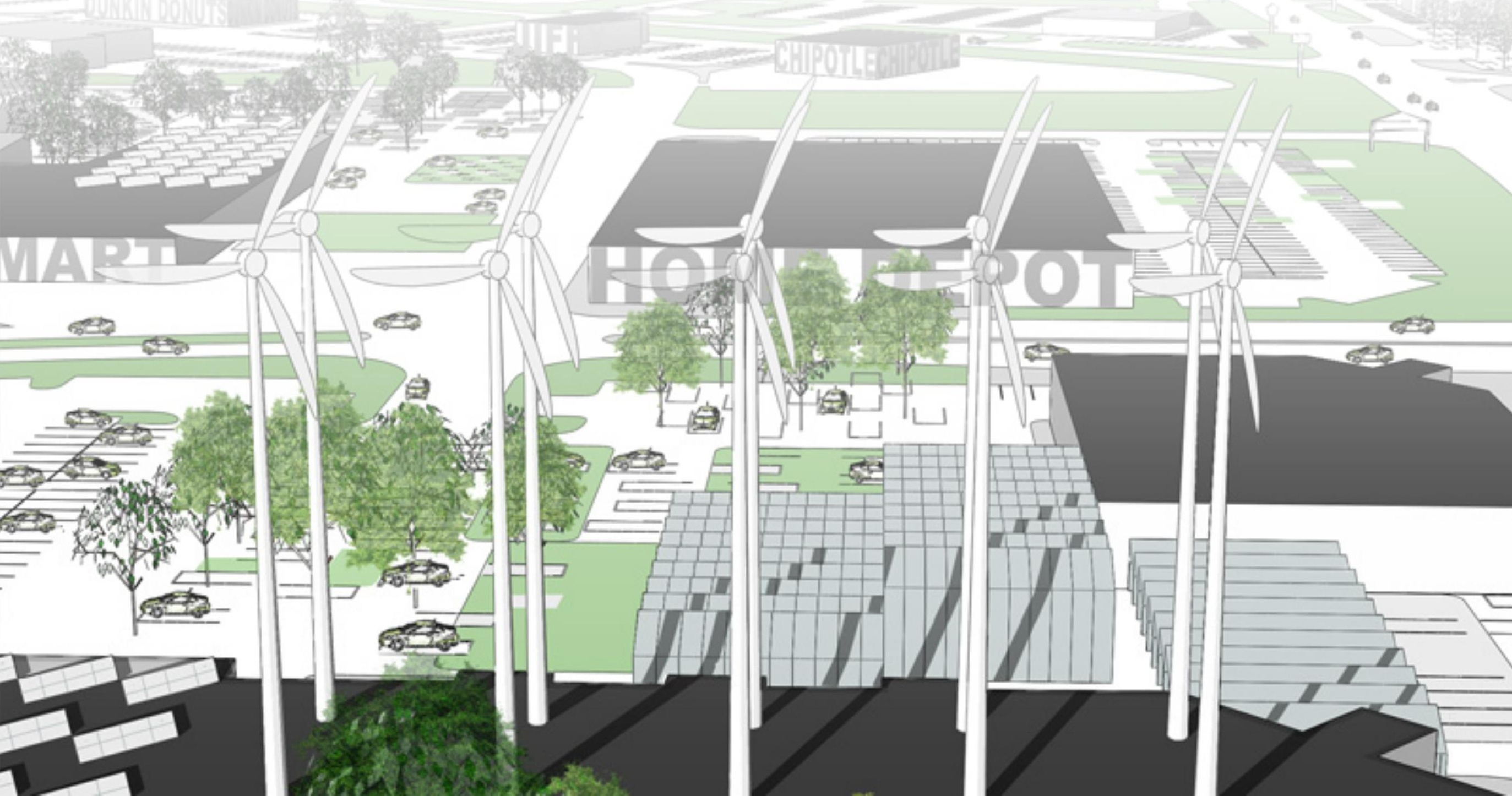


1 Charles Jencks, The Language of Post-modern Architecture (New York: Rizzoli, 1977), 9

\section{CHAPTER 3.1 \\ NEW URBANISM: A CRITICAL ANALYSIS}

The widespread criticism of modernism discussed in Part 2, contained burgeoning threads of a so-called 'postmodern' discourse on architecture and urbanism. During this period, the main concerns for imageability and pedestrianoriented urbanism, became reasons not simply to evolve modernism, but to discount it completely. In The Language of Post-modern Architecture (1977), architectural critic Charles Jencks declared the 'official end of modernism', stating:
"Happily we can date the death of modern architecture to a precise moment in time.... Modern Architecture dies in St Louis, Missouri on July 15, 1972 at 3:32 p.m. (or thereabouts) when the infamous PruittIgoe scheme, or rather several of its slab blocks, were given the final coup de grace by dynamite."

Although it is clear that this transition was much less abrupt than Jencks claims, his statement illustrates a complete loss of faith in modernism, which had become common amongst architects at this time. In this work, Jencks suggests that post-modernism is pluralistic or "hybrid", as it is still partly modern due to its scale, program, and use

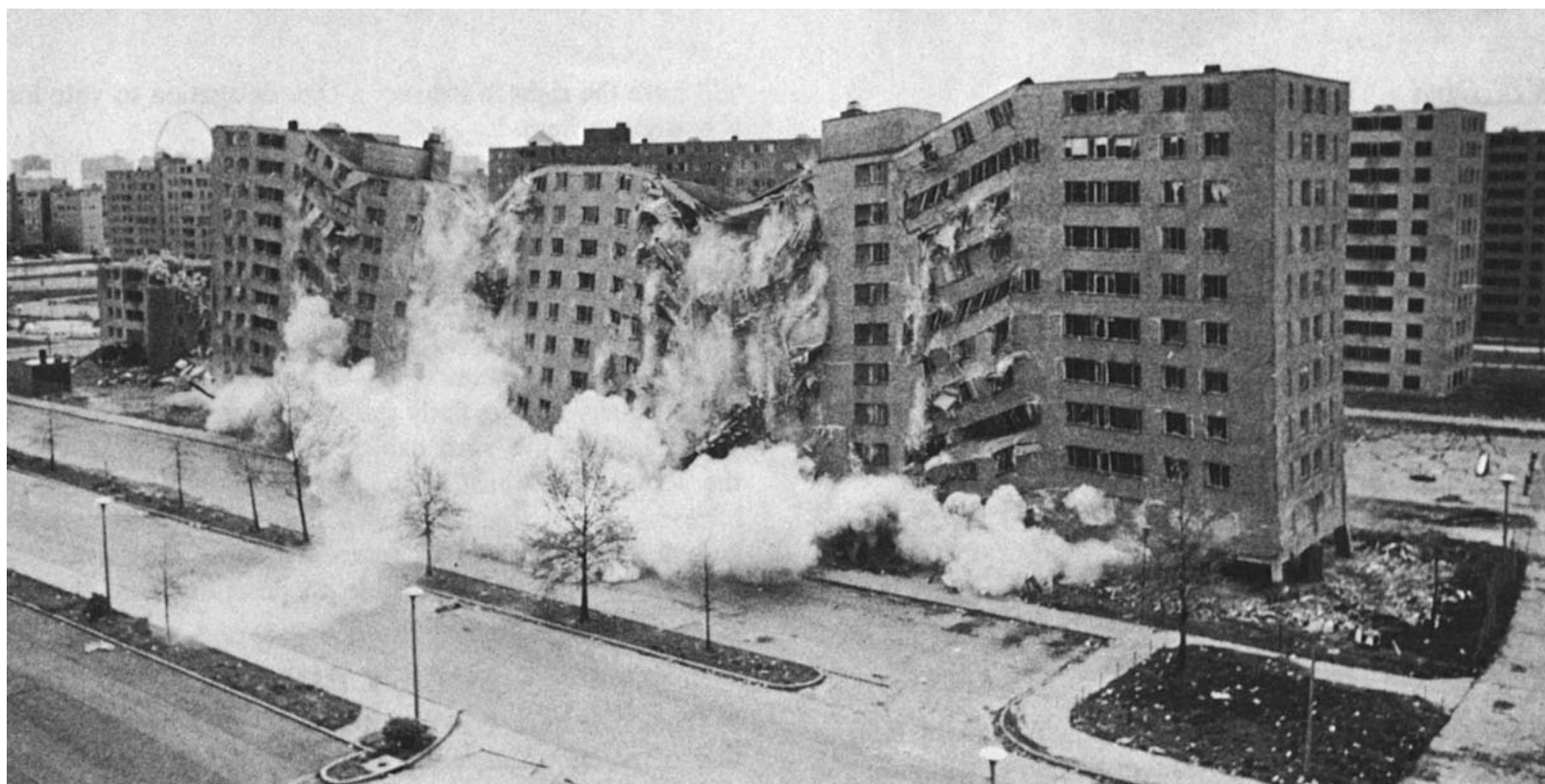

Figure 1: Several of the Pruitt-Igoe towers being demolished in April 1972, St. Louis, Missouri. 
of current technology and structure. ${ }^{2}$ This was certainly true of large-scale postmodern projects in major cities. However, in suburban regions where single-family housing dominated, and populism drove development, historicism took a stronger hold. The response was less a hybrid strategy, and more a complete replication of traditional pre-war architecture and planning. This approach is known as New Urbanism.

Beginning in the 1980s under the guise of "Traditional Neighbourhood Design," the term "New Urbanism" emerged with the formation of the Congress for the New Urbanism (CNU) which released its "Charter of the New Urbanism" in 1993. This charter was designed to directly oppose CIAM's "Athens Charter" (1933). The CNU includes twenty-seven principles for architecture and urban planning, which seek to recreate the qualities of traditional small town neighbourhoods. ${ }^{3}$ New Urbanism takes issue with the formation of super-blocks, lack of human scale, and the distinct separation of uses which characterizes modernist planning. They call for denser, mixed-use, walkable districts with public open spaces like urban 'squares'.
The most influential proponents of New Urbanism have been the Luxembourgborn brothers Rob and Léon Krier (both architects and planners). Rob Krier first published Urban Space in 1975, a volume which sought to understand the traditional form of 'urban space,' which he argued had been lost in modern planning. In this work, Rob Krier identifies the square and the street as the fundamental units of urban space, which are created through the arrangement of built form. ${ }^{4}$ In the third chapter, he proposes a reconstruction scheme for the town of Stuttgard, Germany, for areas which had been damaged in WWII. Rob Krier argued that the new built form had to blend seamlessly into the surrounding context, to ensure that the quality of urban space was not compromised. ${ }^{5}$ Léon Krier's work runs parallel to this theory, with more emphasis on architectural expression. In various manifestos from the 1980s until the present, Léon Krier asserts that modernist architecture has no ability to "make true places." 6 He sees no promise in any strategy but replication of historic typologies.

He argues that modern buildings fail to convey any sense of hierarchy or function, and that they are not built for longevity. ${ }^{7}$ The ideology of the Kriers has been
2 Charles Jencks, The Language of Post-modern Architecture (New York: Rizzoli, 1977), 5

3 " "Charter of the New Urbanism" Congress for the New Urbanism." 1996. In The Urban Design Reader, ed. Michael Larice and Elizabeth Macdonald (London: Routledge, 2007), 308

4 Meliz Kusadali, "Rob Krier: Urban Space (1979)." Architecture Urbanism: A Blog From The Ma Architecture Urbanism Course At The Manchester School Of Architecture (blog), March 25, 2011. Accessed February 12, 2016. http:// architectureandurbanism.blogspot.ca/2011/03/robkrier-urban-space-1979.html.

\section{5 lbid}

6 Léon Krier, The Architecture of Community. Washington (DC: Island Press, 2009), 49

7 lbid, 43 
8 "Poundbury." The Prince of Wales and the Duchess of Cornwall. Accessed February 12, 2016. http://www. princeofwales.gov.uk/features/poundbury.
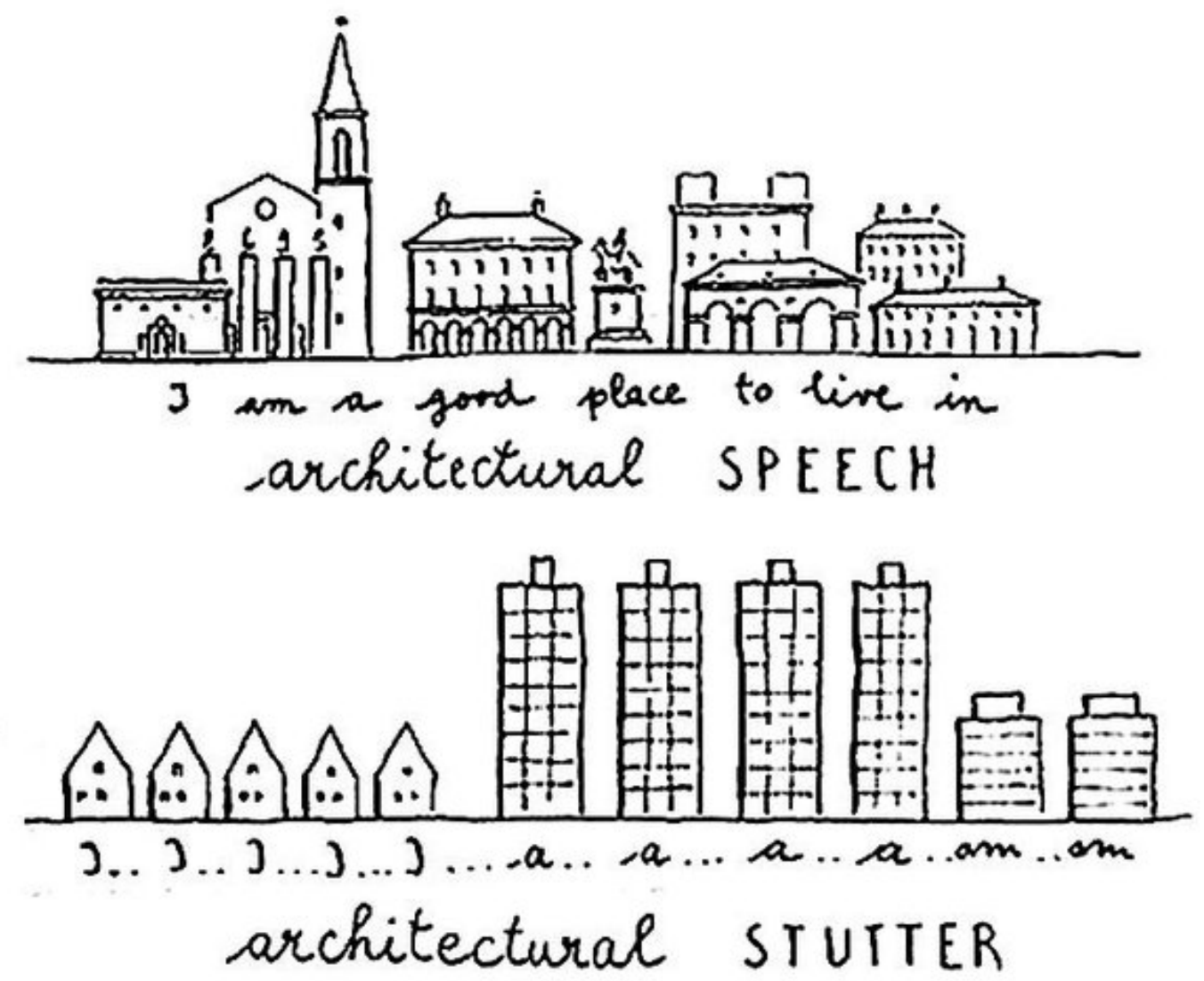

Figure 2: Sketch by Leon Krier which satirizes the lack of hierarchy in modernist environments

demonstrated by their speculative and built projects including the Town of Poundbury in the United Kingdom, which was awarded to Léon Krier by The Prince of Wales in 1988 (construction began in 1993). ${ }^{8}$ Their theory has become the foundation of New Urbanist doctrine.

The influence of Rob and Léon Krier quickly found its way to North American postmodern architects such as Floridabased Andrés Duany and Elizabeth PlaterZyberk (the husband and wife team of the Duany Plater-Zyberk \& Company). Their project for the community of Seaside, Florida (1981) has become the poster-child for New Urbanism. The plan is organized around a central town square with a neoclassical post office at the centre. The town is mostly composed of large single-family 


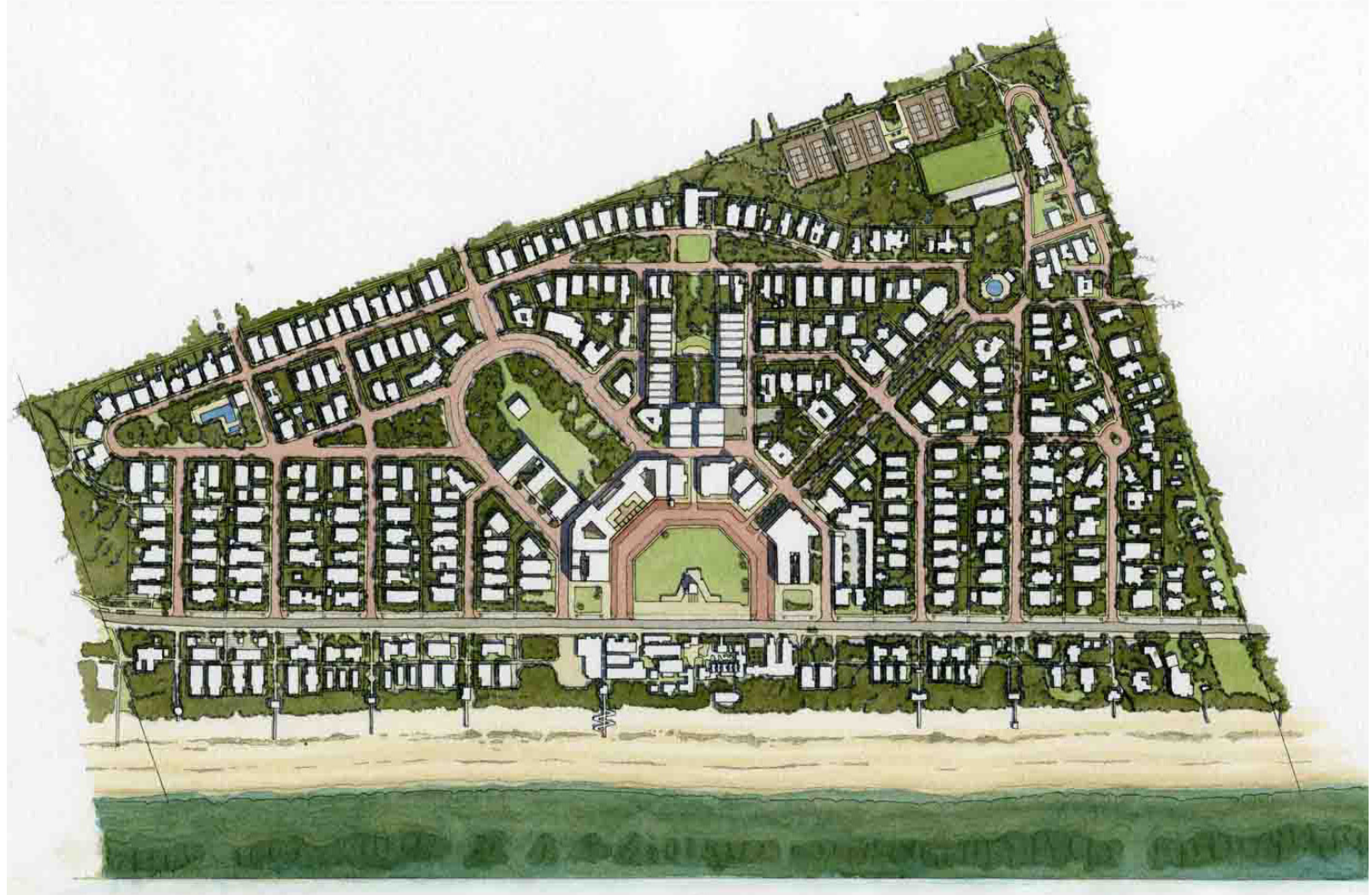

Figure 3: Updated Plan of Seaside, Florida by Andrés Duany and Elizabeth Plater-Zyberg

homes which are designed to resemble historic architecture. Seaside has been well received by residents, but highly criticized by architects and critics alike. In Architecture and Suburbia (2005), John Archer describes the Seaside model as an attempt to reclaim a sense of "community" or "family" through a replication of the past and disregard of the present. He argues: "to suggest that they could be exported to a different time and place in order to clone certain admired aspects of the past would be to violate principles of both architecture and history."

\section{Although it has been quite} popular amongst the general public, New Urbanism has seen its fair share of criticism. One commonly cited problem is that New Urbanist methodology rests
9 John Archer, Architecture and Suburbia: From English Villa to American Dream House, 1690--2000 (Minneapolis: University of Minnesota Press, 2005), 343 


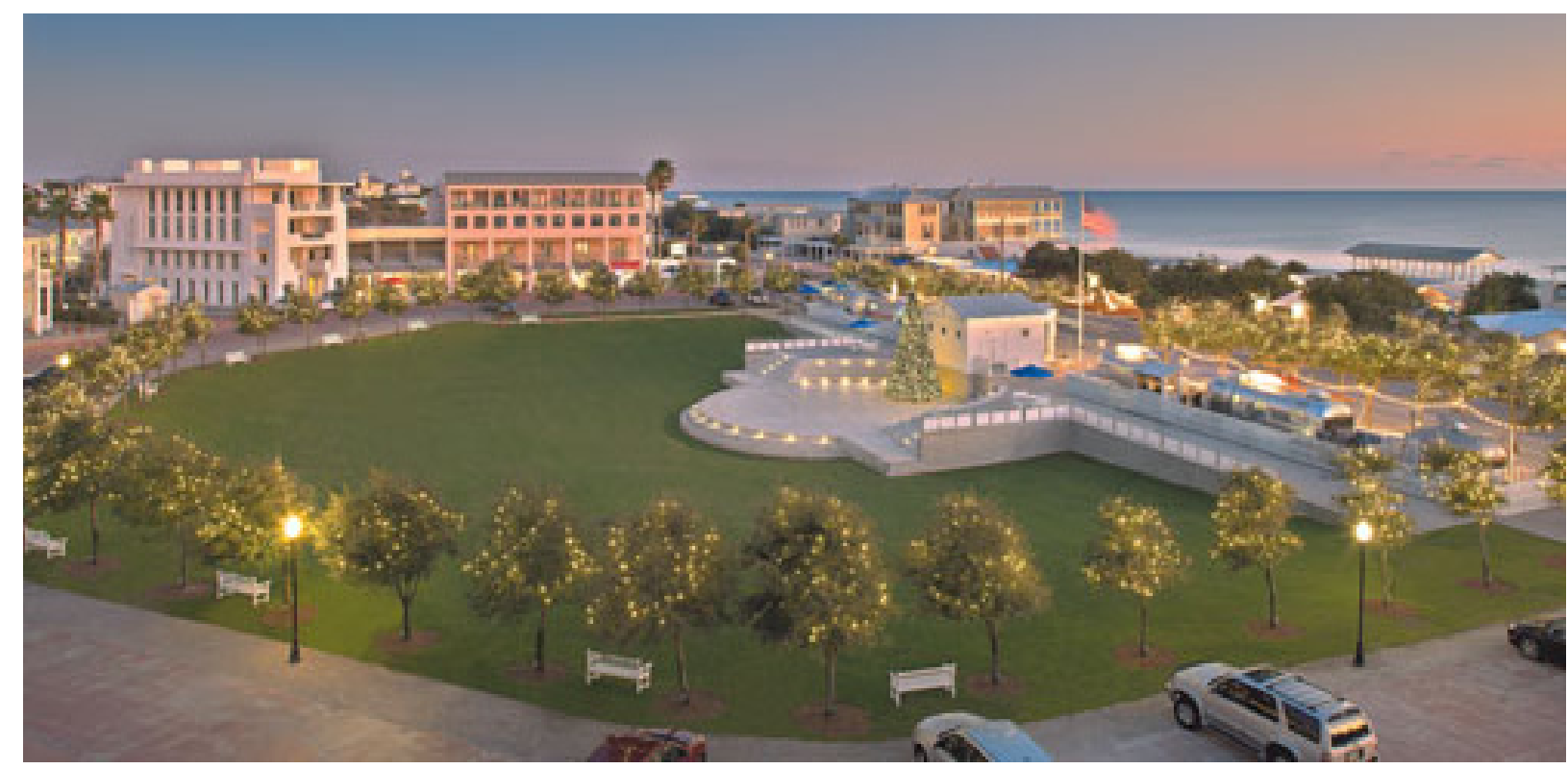

Figure 4: Town Square in Seaside, Florida

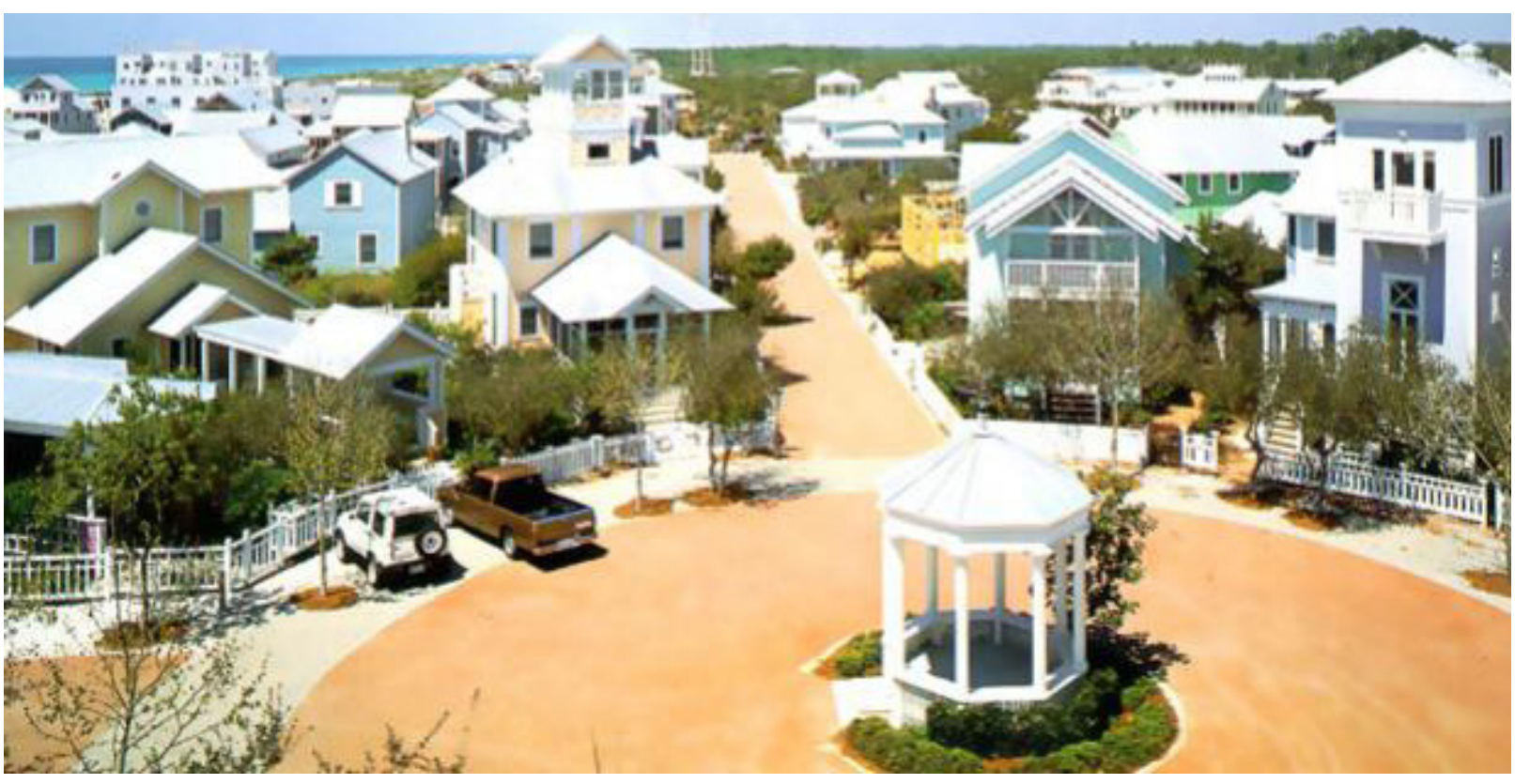

Figure 5: Homes in Seaside, Florida 
on a complete tabula rasa strategy. This is paradoxical, not only because the destruction of existing fabric would be particularly wasteful, but because of market forces, these developments have largely only been achieved on greenfield sites; thus contributing to the 'sprawl' that they sought to combat. Besides this, New Urbanism's use of unapologetic historicism is the number one issue for critics. Even New Urbanists themselves recognize that there are typologies and conditions in the contemporary world which do not readily configure into a pre-war planning and aesthetic. New Urbanist Daniel Solomon admits:

"...the New Urbanist cosmos does not engage large segments of what are inescapable parts of the contemporary landscape - vast infrastructure projects and facilities for the distribution of goods at the scale of the global economy; ie. The IKEAs and Wal-Marts of the world. It is quite true that there is no such thing as a new urbanist airport. "10

This quote speaks volumes about the inability of pre-modern architecture to accommodate the typologies and programs of the contemporary world. When this is attempted, the 'historic' quality is only used as facade to an otherwise modern building,

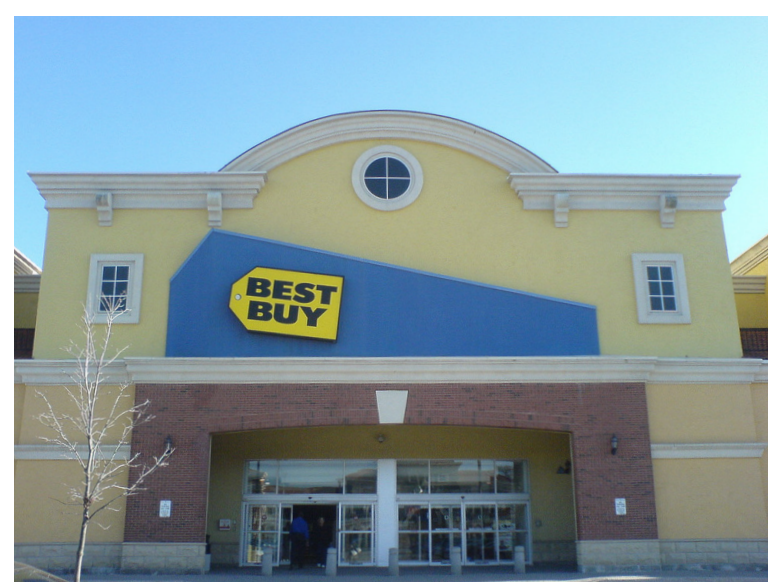

10 Daniel Solomon, "Why Dogs Should Not Eat Dogs," in Landscape Urbanism and Its Discontents: Dissimulating the Sustainable City, ed. Andres Duany and Emily Talen ( Gabriola Island, BC: New Society Publishers, 2013), 166

11 Dana Cuff and Roger Sherman, Fast-forward Urbanism: Rethinking Architecture's Engagement with the City (New York: Princeton Architectural Press, 2011), 15
Figure 6: A Best Buy store in Leaside, Toronto with a faux-heritage design

resulting in a distorted and often cartoonish appearance. (Figure 6)

In this vein, many critics have suggested that New Urbanism simply "substitutes one manifesto for another". In Fast Forward Urbanism (2011) editors Dana Cuff and Roger Sherman argue:

"[New Urbanism's] vision and principles are equally unable to deal with the messiness of existing conditions and the market forces that control them. It indiscriminately borrows an urban imaginary from an earlier model of city life, and fails to recognize how the forces that produce cities today have radically changed-in the scale of increments of development, instruments of financing, audiences, and implicit lifestyles. "11 
12 Paul Lukez, Suburban Transformations (New York: Princeton Architectural Press, 2007), 15
Similarly, while New Urbanism seeks to rectify the universalizing quality of orthodox modernism, its reliance on a strict architectural language limits its ability to convey locality or any specific expression. ${ }^{12}$ New Urbanist communities are criticized for being 'instant' in much the same way that modernist 'new towns' were. In most cases the expression is just as repetitive as modernist suburbs, if not more so.

This thesis is largely an effort to provide an alternative to New Urbanism, that takes into account the past and current modernity of the postwar suburbs. The practice of referencing a history which never existed is only preventing suburbs from becoming relevant and recognizable places. As it will be further explored in Part 4, new cities and suburbs in the Netherlands (and some Scandinavian countries) have embraced their modernity and created imageability out of their newness. 


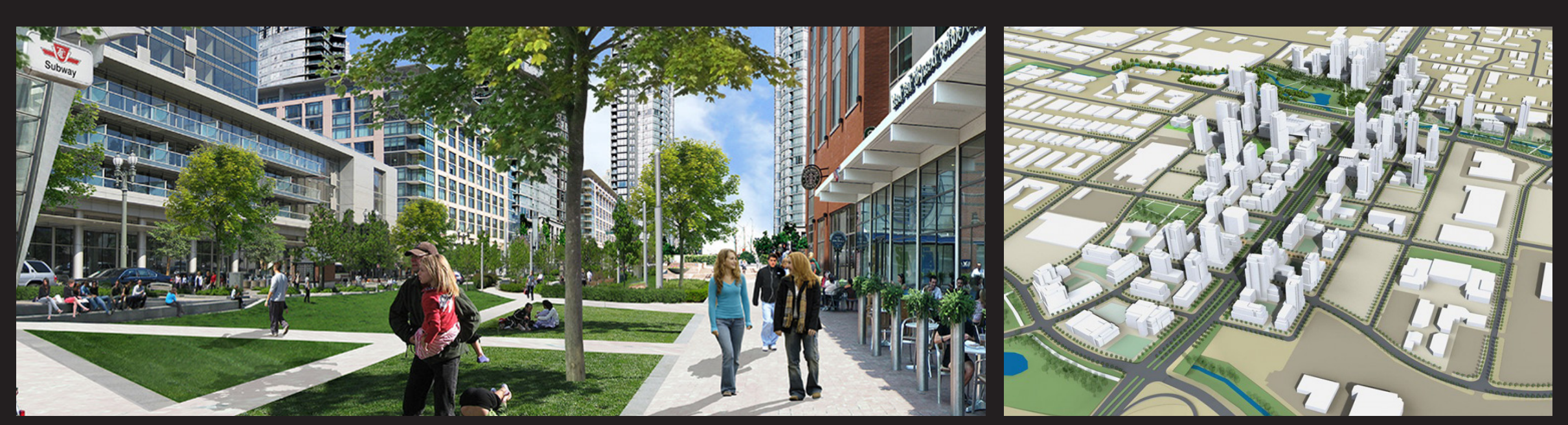

Figure 7 (above): Images from the City of Vaughan Metropolitan City Center Secondary Plan (2008-2010), by Urban Strategies

\section{SMART GROWTH: A NEW-NEW URBANISM?}

In recent years New Urbanism has spawned a sub-movement called "Smart Growth". In the last decade, Smart Growth has become the conventional strategy for large scale development planning in Canada. It focuses on the sustainable nature of walkable, densely populated neighbourhoods, but does not always follow the neo-traditional architectural doctrine of New Urbanism. Smart Growth is guided by a desire for increased residential density. As such, recent developments have been primarily composed of high-rise residential towers with commercial at grade. Unfortunately this pursuit of density has overpowered the desire for architectural hierarchy or the formation of distinct landmarks and places. This is likely because architects are rarely involved in the master planning of large development projects until much later stages. At this point, they are given formulaic and inflexible restrictions which do not encourage a variety of urban forms and spaces. (Figure 8) It is clear that density alone does not produce great urbanism.

Figure 8 (right): Prototype from the City of Toronto's Tall Building Design Guidelines (2007-2008), by Urban Strategies

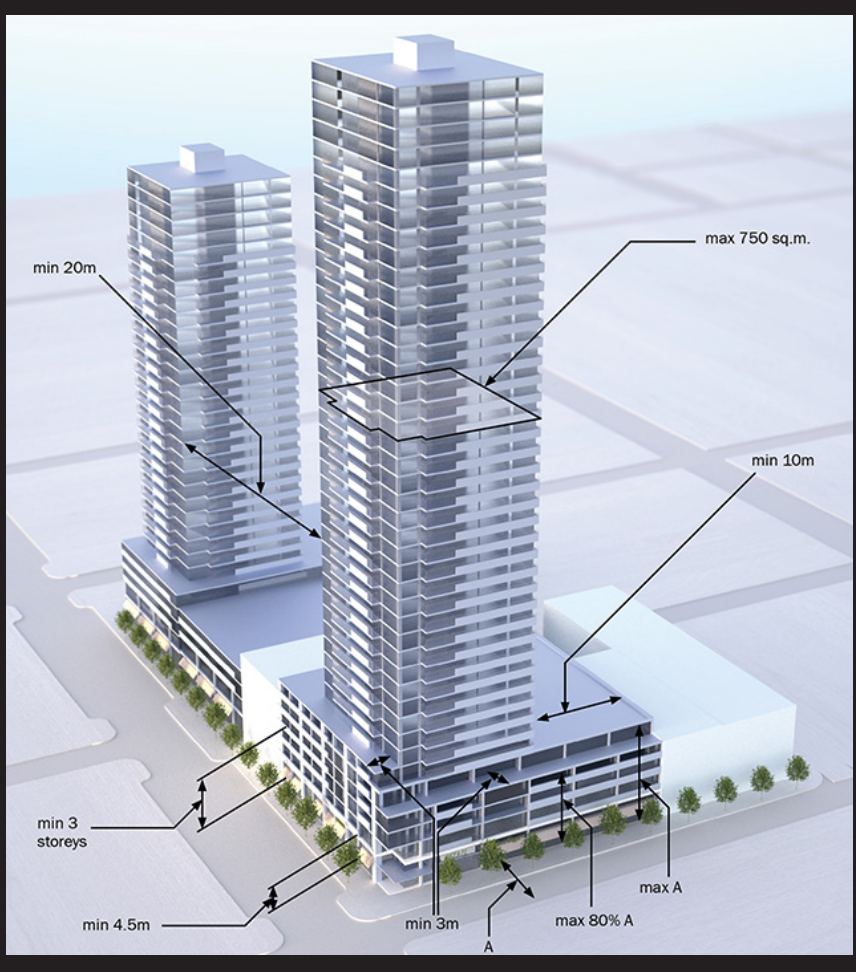


1 Bruce Donnely, "Absorbing Landscape Urbanism," in Landscape Urbanism and Its Discontents:

Dissimulating the Sustainable City, ed. Andres Duany and Emily Talen (Gabriola Island, BC: New Society

Publishers, 2013), 191

2 Charles Waldheim, The Landscape Urbanism Reader (New York: Princeton Architectural Press, 2006), 11

3 Andres Duany and Emily Talen, Landscape Urbanism and lts Discontents: Dissimulating the Sustainable City (Gabriola Island, BC: New Society Publishers, 2013), Xiii

4 Charles Waldheim, "Landscape as Urbanism." In The Landscape Urbanism Reader, ed. Charles Waldheim (New York: Princeton Architectural Press, 2006), 65

\section{CHAPTER 3.2 \\ LANDSCAPE URBANISM: A CASE FOR MODERNIST ENVIRONMENTS?}

By the mid-1990s, Landscape Urbanism emerged as a competing discourse to New Urbanism. One of the most influential voices of this movement, Charles Waldheim, has admitted:

"Landscape Urbanism was specifically meant to provide an intellectual and practical alternative to the hegemony of the New Urbanism." 1

As such, New Urbanism and Landscape Urbanism represent polar ends of the spectrum. Landscape Urbanism's principal objective is to realign the organization of space so that "landscape replaces architecture as the basic building block of contemporary urbanism." 2 While New Urbanists focus on creating streets, building frontage and walkable distances, Landscape Urbanism attempts to tackle the sustainability issues of suburban places by applying productive landscape across its surfaces. ${ }^{3}$ Landscape Urbanists conceive of the 'site' as a larger metropolitan area which is governed by natural systems, and aspire to create an ecological harmonious environment. The admirable aspect of
Landscape Urbanism is its investigation into new ways of creating more sustainable environments without resorting to premodern models. It is a response which emerges out of the conditions of the place. Charles Waldheim explains:

"Landscape urbanists want to continue the search for a new basis of a performative urbanism that emerges from the bottom up, geared to the technological and ecological realities of the postindustrial world."4

Landscape urbanism is particularly relevant to the discussion on the transformation of modernist environments, because it is often presented as a strategy for a redemption for modern landscapes; with the notion that distance and horizontality can be seen as an asset.

Some scholars have suggested that the ample space of suburban areas could provide opportunities for sustainable technologies which could not exist within hyper-dense cities. In Sprawl: A Compact History (2005), Robert Bruegmann suggests,

"At low enough densities, most citizens would probably be able to generate, using wind, water, solar, and geothermal power sources, a great deal of the energy they 


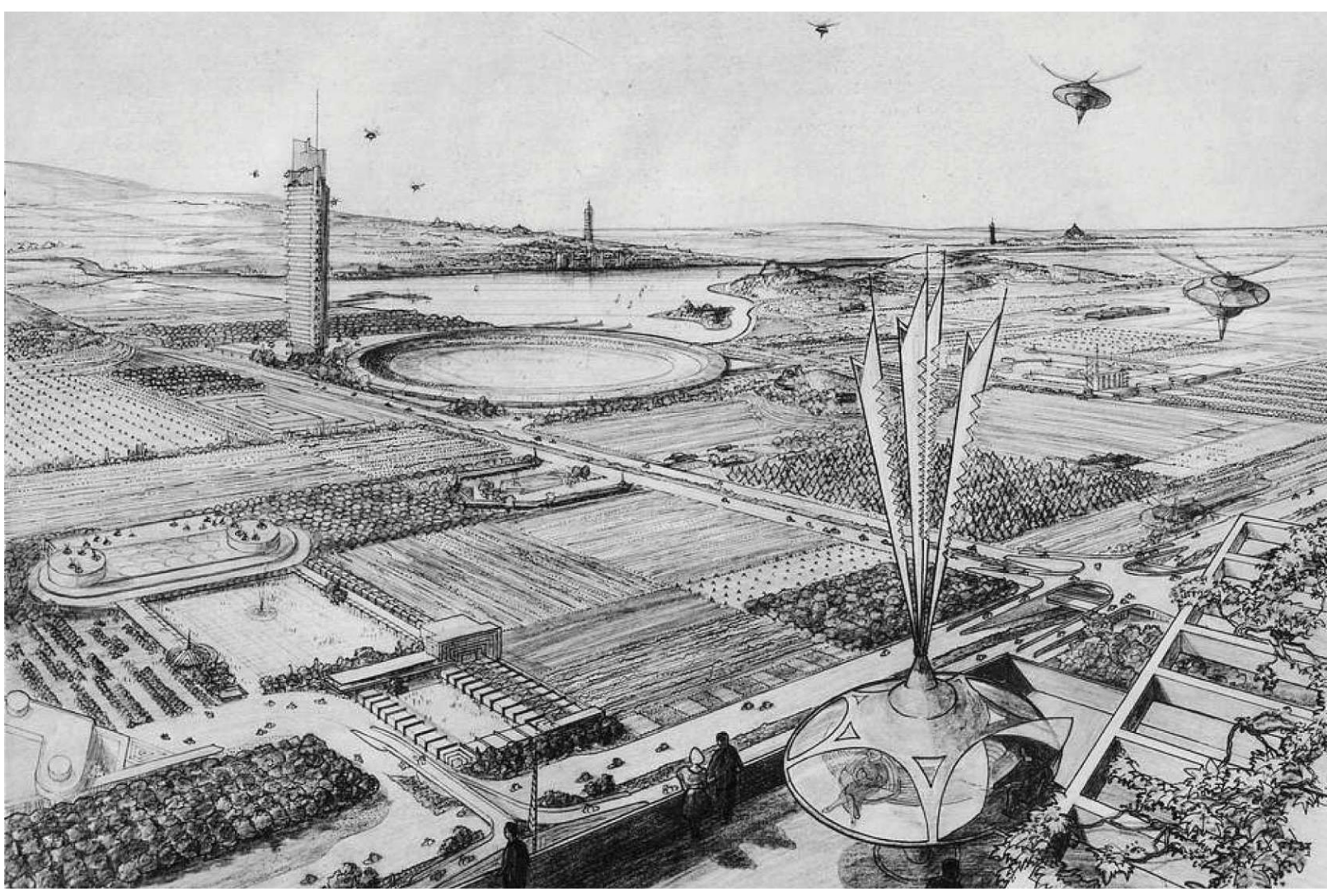

Figure 1: Frank Lloyd Wright's "Broadarce City" (1958)

need on their own land, much like the New England farmer did in the nineteenth century. "5

This perspective indicates a kinship with Frank Lloyd Wright's ongoing "Broadacre City" proposal. (Figure 1) It has also been suggested that Landscape Urbanism is potentially compatible with postwar modernist ideas of mat urbanism. Architect Stan Allen explains:
"Mat urbanism would in turn connect to the recent tendencies in landscape architecture, where the "thick 2D" of the forest, field, or meadow creates mat like effects of connectivity and emergence. ${ }^{6}$

Allen suggests that there has been a "newly emerging interest in topological surfaces" and cites Foreign Office Architects' Yokohama Port Terminal as an example of a contemporary mat building. Allen describes
5 Robert Bruegmann, Sprawl: A Compact History (Chicago: University of Chicago Press, 2005), 149

6 Stan Allen, "Mat Urbanism" Thick 2D." In CASE: Le Corbusier's Venice Hospital, ed. Hashim Sarkis (Munich: Prestel, 2002), 123 
7 Stan Allen, "Mat Urbanism" Thick 2D." In CASE: Le Corbusier's Venice Hospital, ed. Hashim Sarkis (Munich: Prestel, 2002), 119-120

8 Lateral Architecture, "Flatspace: Resurfacing Contemporary Public Space", in World's Away: New Suburban Landscapes, ed. Andrew Blauvelt (Minneapolis: Walker Art Center, 2008), 235

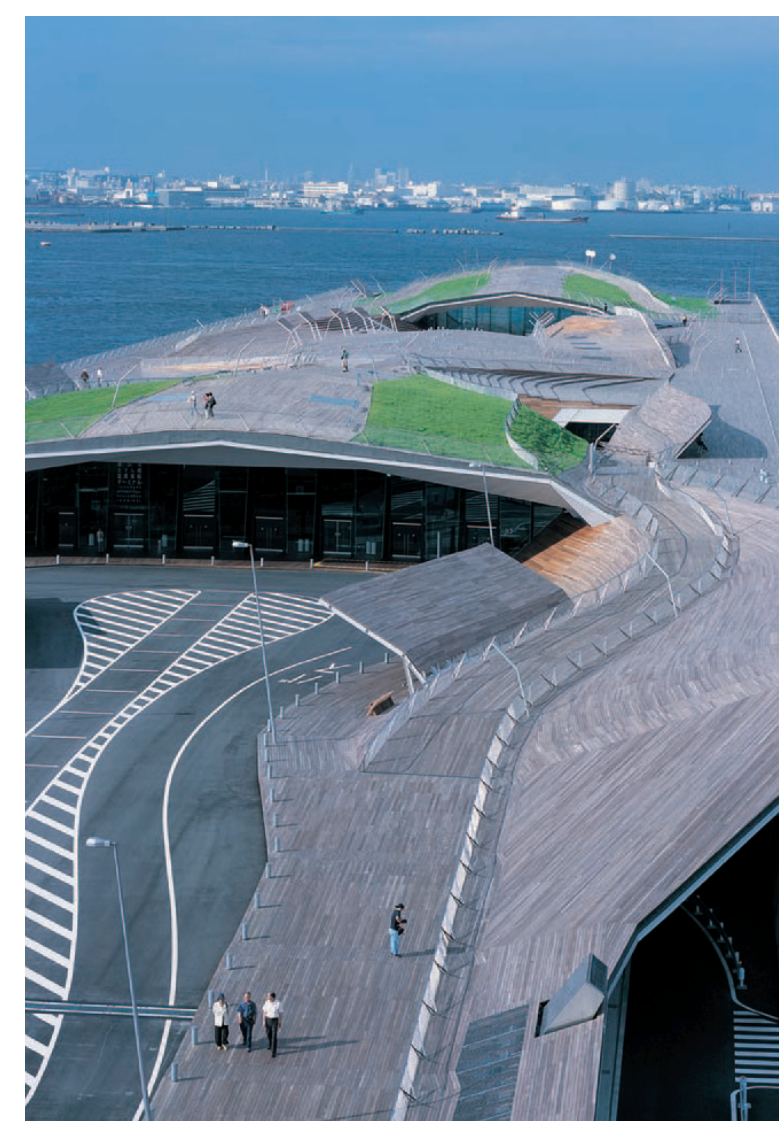

Figure 2: Yokohama Ferry Terminal, Foreign Office Architects (2002)

the design as:

"a porous mat of movement and waiting spaces by means of warped and folded steel plates... Garden and building are simply differing intensities of occupation occurring along a more or less continuous surface. Conceived as an artificial landscape, minimal sectional variation separates and smoothes traffic flows at the same time that it activates complex programmatic variation. "7

The conception of space as a continuous surface shows an integration between architecture and landscape, while allowing for various programs to take place.

Like mat buildings, the concept of the megastructure can also be re-examined through the lens of Landscape Urbanism. In Chapter 2.3, the apparent "failures" of the megastructure were identified as enormous scale, and a lack of connection to the exterior and existing context. However, it is apparent that the most successful examples were those which succeeded in creating an accessible constructed landscape, thus extending the public street life rather than impeding it. One such example is Robson Square, the public space created on the roof of the Provincial Government Offices in Vancouver (1980), by Arthur Erickson. (Figure 4)

Given the prominence of landscape in postwar suburbs (as discussed in Part 1), Landscape Urbanism certainly has a role to play in the future transformation of suburbs. However, this must be done with a critical stance. A blind adoption of this approach could potentially repeat the same problems of orthodox modernism. Understanding 


\section{CASE STUDY: \\ "FLATSPACE" \\ LATERAL OFFICE}

This project by Lateral Office explores the different functions that suburban 'flatspace', such as parking lots and highway off-ramps can take on, through the application of productive landscapes and sustainable technologies. The architects explain:

"How can one transform this environment to respond to its unlikely status as an essential contemporary public space? This question inspired several design proposals that reconfigure the "ingredients" of these landscapes, forging new connections, experiences, and definitions of public space. We selected three key elements of flatspace to modify: program, parking and landscape... Rather than introduce new elements, each scheme tests the modifications of existing ones. ${ }^{1 / 8}$

"Flatspace" indicates a compatibility with landscape urbanism, as it proposes new surface treatments for the horizontal expanses of suburbia. Very little built form is proposed.

Figure 3: 'Flatspace' by Lateral Office
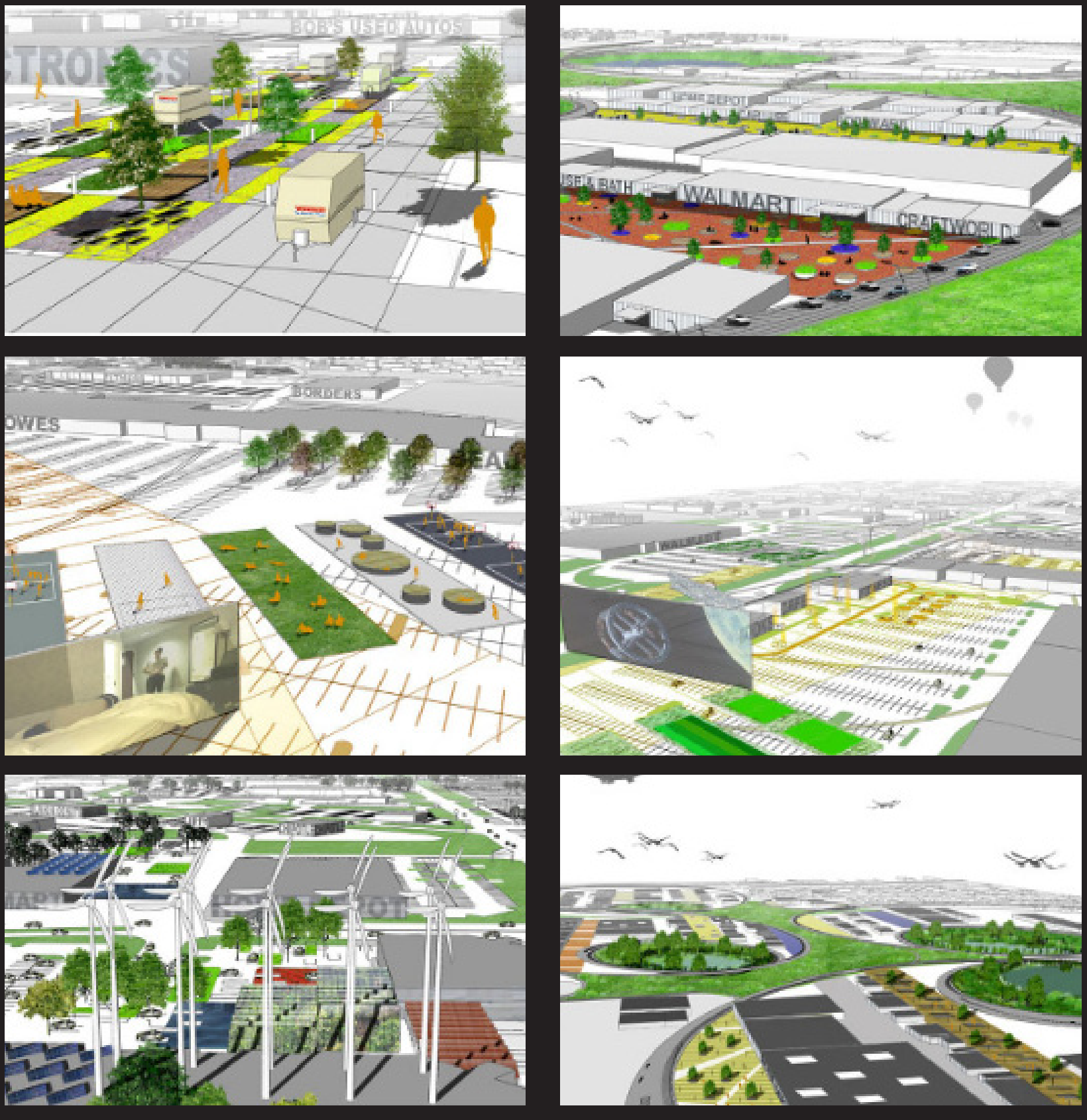
9 Andres Duany and Emily Talen, Landscape Urbanism and lts Discontents: Dissimulating the Sustainable City (Gabriola Island, BC: New Society Publishers, 2013), 28

10 Michael Dennis And Alistair Mcintosh, "Landscape and the City," in Landscape Urbanism and its Discontents: Dissimulating the Sustainable City (Gabriola Island, BC: New Society Publishers, 2013),47

11 "Rafael Viñoly Plans World's Largest Green Roof for Silicon Valley." Dezeen. September 09 2015. Accessed February 13, 2016. http://www. dezeen.com/2015/09/09/rafael-vinoly-reveals-planslargest-green-roof-in-world-silicon-valley-cupertinocalifornia/.

$12 \mathrm{lbid}$

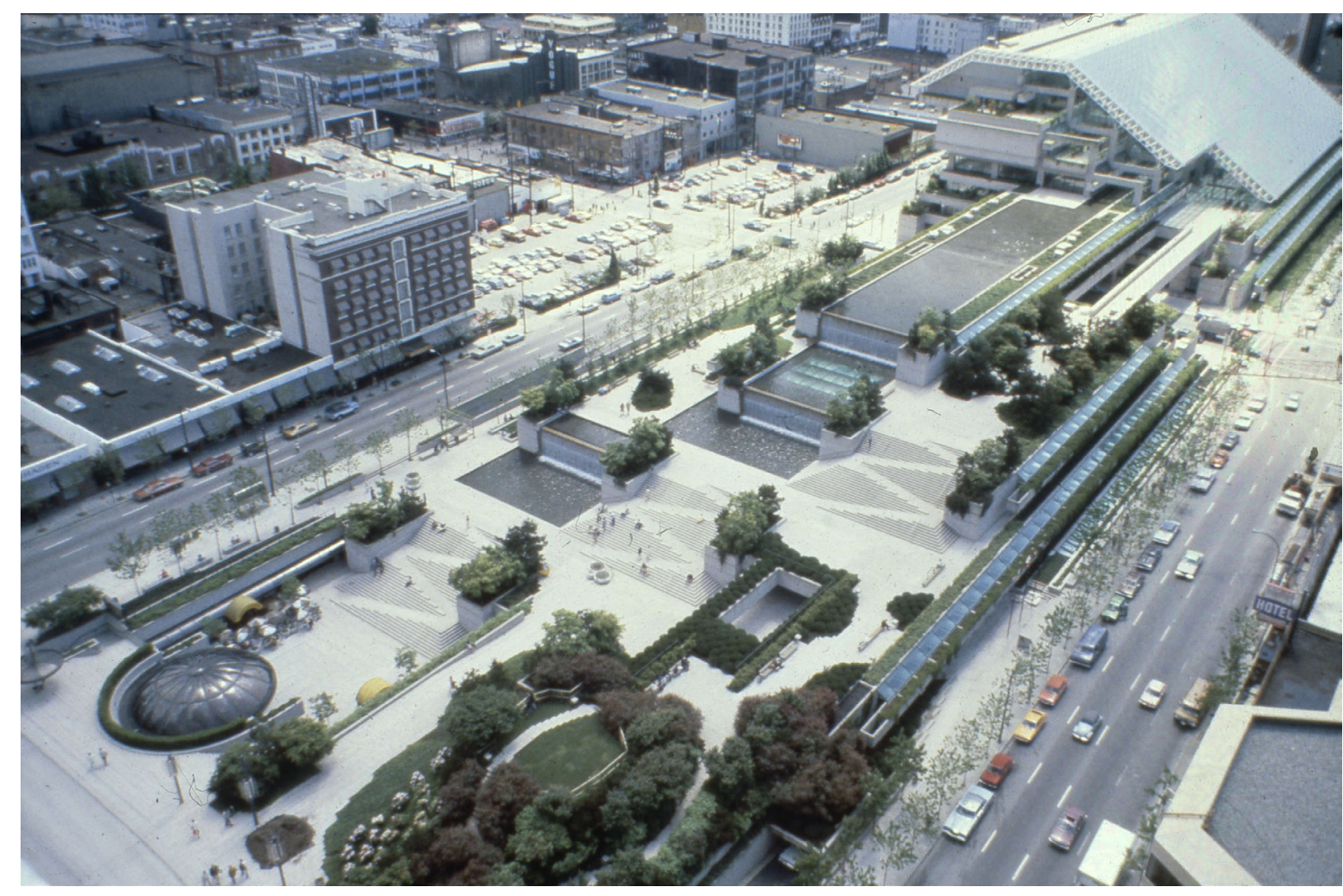

Figure 4: Vancouver Law Courts, Robson Square, Arthur Erickson (1980)

the site as a continuous surface or "mat" is an interesting starting point, but inevitably there needs to be distinctive landmarks which provide contrast. Otherwise, the result is too monotonous. New Urbanists frequently debate that Landscape Urbanism theory disregards the need for walkable networks or human scale of urban places. They see "the street" as the critical difference between their respective ideologies. For New Urbanists, the presence of physical streets supported by built form is non-negotiable. ${ }^{9} \mathrm{New}$ Urbanists Michael Dennis and Alistair Mcintosh explain:

"Landscape as the city is simply not enough; it's an incomplete paradigm If the ominous urban and environmental issues of the twenty-first century are to be addressed, a more comprehensive strategy involving architecture, landscape and urban design must be used."10 
Thus if we are to embrace the integration of landscape into architectural form, then human scale and the creation of programmed public space must be kept in mind. Landscape shouldn't serve to replace architecture or street networks, but rather architecture could better create and support landscape and urban spaces. This critical approach is highly compatible with the strategies discussed in Part 5.

\section{CASE STUDY: \\ "THE HILLS AT VALLCO" - RAFAEL VIÑOLY + OLIN LANDSCAPE ARCHITECTS}

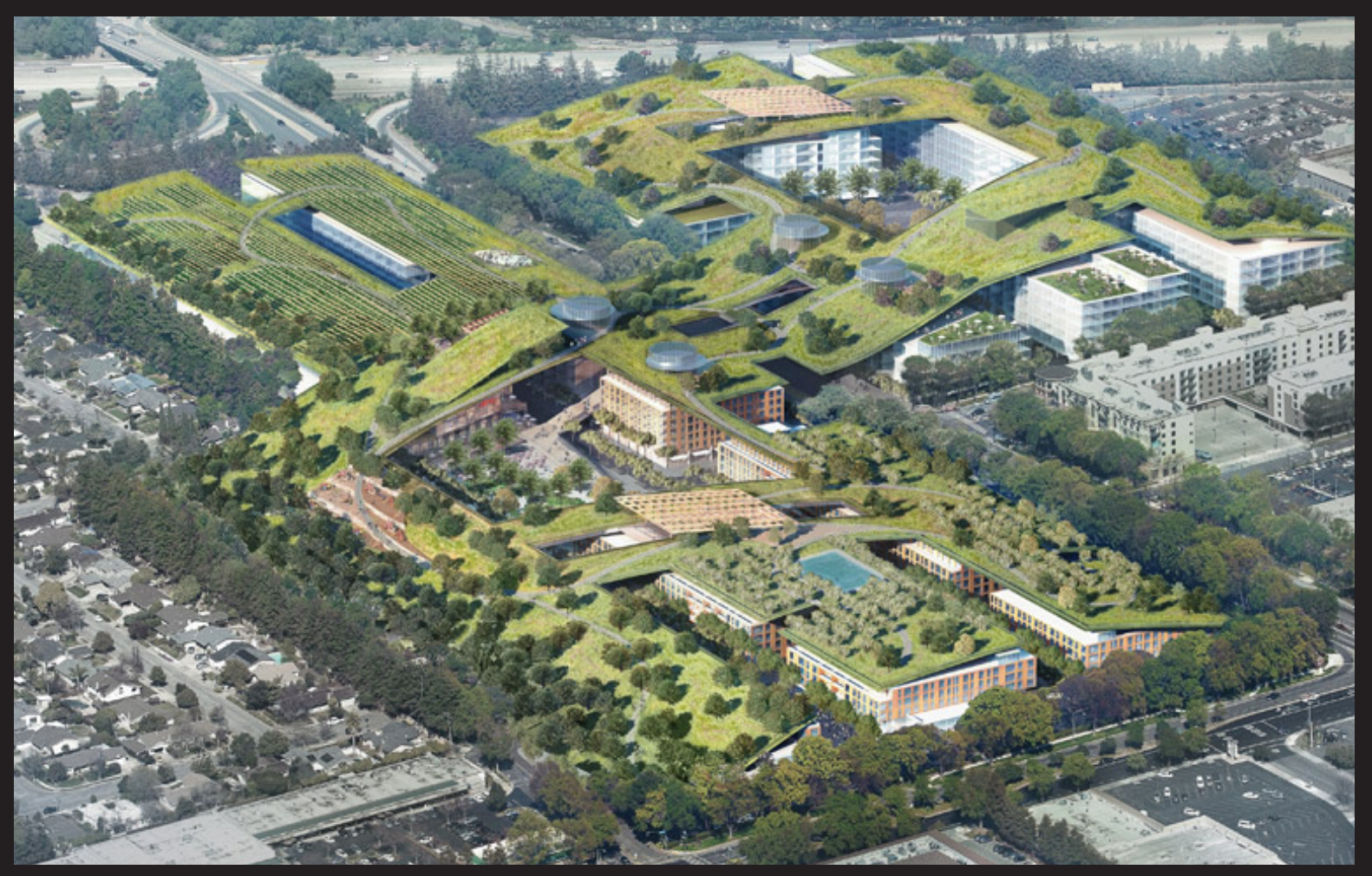

Figure 5: Image of "The Hills at Vallco" from Rafael Viñoly + Olin Landscape Architects

The Hills at Vallco will replace the existing Vallco Shopping Malls in Cupertino, California. The development will include up to "800 apartments, 185,000 square metres of office space and a new shopping centre containing a cinema, bowling lanes, an ice rink and gym". ${ }^{11}$ Above the entire complex will be a 30 -acre green roof; which (if built) will be the largest in the world. The green roof is designed to provide a buffer to the surrounding context, and support walking trails, vineyards, orchards, playgrounds, and native planting. ${ }^{12}$ The project appears to be a 21 st century mat building, integrated with landscape urbanism principles. 
1 Robert Bruegmann, Sprawl: A Compact History (Chicago: University of Chicago Press, 2005), 9

\section{CHAPTER 3.3 \\ NEW SUBURBAN HISTORY: AN ANALYSIS OF POTENTIAL}

While New Urbanism and Landscape Urbanism represent radical extremes to transforming postwar suburbia, in recent years there has been an emergence of a more analytical approach, which strives to understand the inner workings of suburban places before jumping to accusatory conclusions. This field of research has come to be known as "New Suburban History". In the introduction to Sprawl: A Compact History (2005), Robert Bruegmann explains the reasons for his research, stating:

"The existing literature was clearly inadequate, not only because the data were incomplete and out-of-date but also because so much of it was based on narrow assumptions about what constitutes urban life."

This field of research supports the notion that suburbia is a valid form of urbanism which is not yet understood, and not yet fully formed. It attempts to shed widespread pessimism about suburbia, and identify potential opportunities within this context.
One aspect of New Suburban History is the study of the actual social conditions of contemporary suburbs. In the early days of postwar suburbia, there was a mostly homogenous culture of white, middle-class families with young children. However, this is not representative of the present condition. It has been extremely well documented that suburban areas in both Canada and the United States are becoming increasingly multicultural and diverse. This trend has become so powerful, that it is now more common for immigrants to settle in suburban areas immediately, instead of going through major cities. This phenomenon is largely due to immigration policies, as well higher real estate values in central cities that have pushed lower income individuals and families out to the fringes. Research shows that in reality, cities are becoming more like suburbs, and vise versa. While aspects of the industrial city like congestion, crime, poverty, racial and ethnic diversity, cultural amenities, and retail diversity are finding their way to the suburbs, the city is fast becoming the gentrified realm of the wealthy. Cities have taken on qualities which were once considered characteristically suburban, including big box retailing, shopping malls, high end boutiques, and an influx of white 


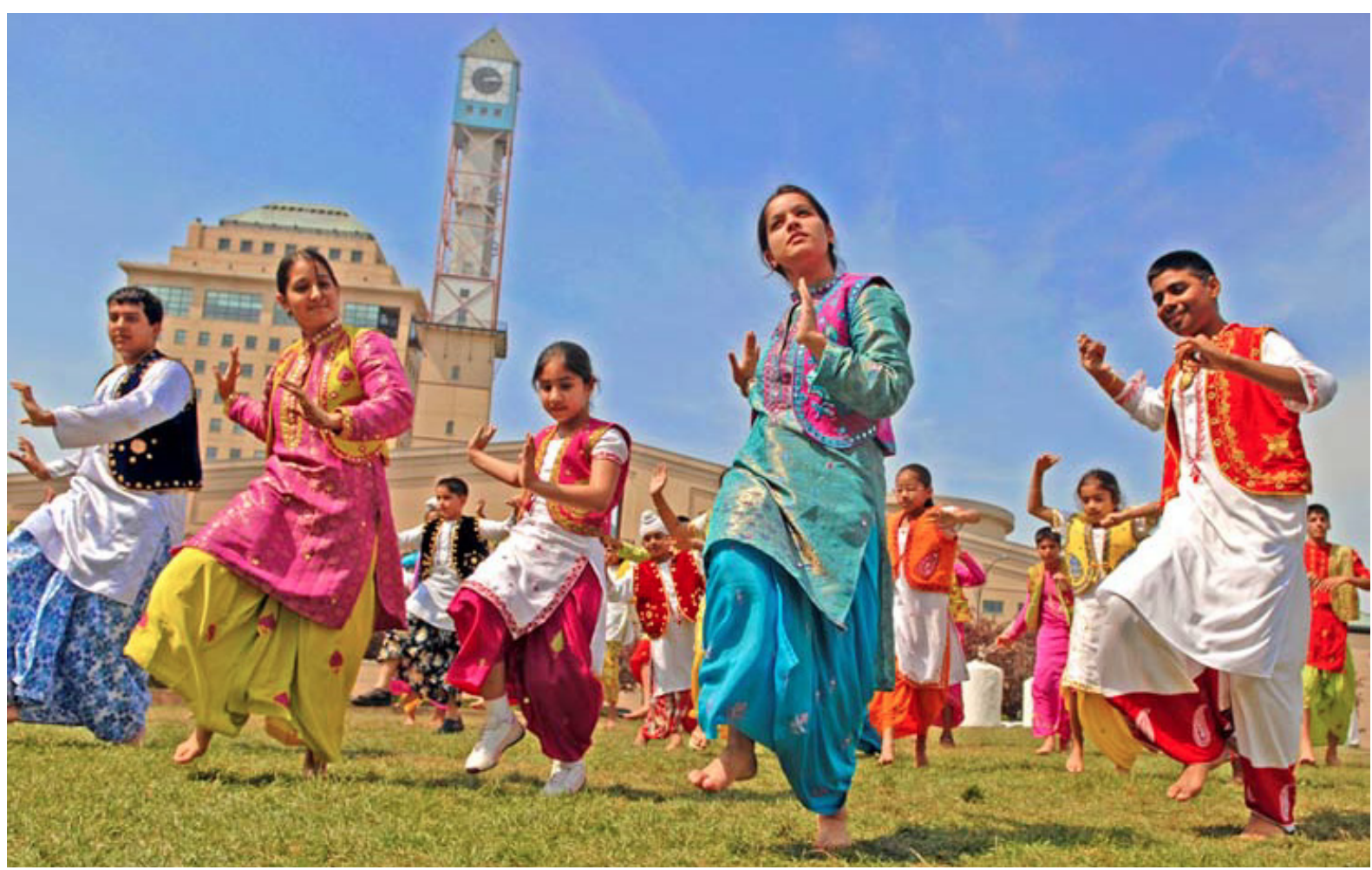

Figure 1: 'My Mississauga' events in Downtown Missisauga

middle (and upper)-class residents. ${ }^{2}$ Robert Bruemann explains,

"Gentrification at the center and sprawl at the edge have been flip-sides of the same coin. In a typically paradoxical situation, no matter how much the new, more affluent residents profess to like the "gritty" urban character of the place, so different in their minds from the subdivisions of the far suburbs, what makes the neighbourhood attractive today are less the things that are actually traditionally urban but those that
Thus, within this trend of "urbanizing' the suburbs, there lies opportunity for suburban places to become more complex and dynamic.

It is often assumed that suburban areas do not contain culture or a "sense of community" because of separation and distances between land uses. This notion finds its genesis in early critiques
2 Andrew Blauvelt, "Preface: Worlds Away and the World Next Door" in Worlds Away: New Suburban Landscapes, (Minneapolis: Walker Art Center, 2008), 11

3 Robert Bruegmann, Sprawl: A Compact History (Chicago: University of Chicago Press, 2005), 4 
4 Alison L. Bain, Creative Margins: Cultural Production in Canadian Suburbs (Toronto: University of Toronto Press, 2013), 87

\section{$5 \mathrm{lbid}, 77$}

6 Margaret Crawford, "Afterword" in Making Suburbia:New Histories of Everyday America, ed. John Archer, Paul J. P. Sandul, and Katherine Solomonson (Minneapolis: University of Minnesota Press, 2015), 385

7 David Kolb, Sprawling Places (Athens: University of Georgia Press, 2008), preface of suburbs discussed in Chapter 2.1. New Suburban Historians argue that there is culture and community in suburbs, but that these qualities are less identifiable to passersby. For her book Creative Margins: Cultural Production in Canadian Suburbs (2013), Alison Bain has conducted research on cultural workers in Canadian suburban areas. She advocates that suburbs are not cultural wastelands, but that there is an active population of creative professionals. Bain notes that the lower real estate values in the suburbs actually provide opportunities for artists to have their own spaces. ${ }^{4}$ She also explains how artists find that easier access to landscapes is a huge source of inspiration. ${ }^{5}$ Bain asserts that while there is cultural production in the suburbs, there are not as many venues in which to view this culture. It is not highly legible.

It is also important to establish the difference between a so-called "sense of community" and a physical "public realm". The word "community" has taken on a more broad definition in present times. In a progressively digital and globalized world, today's identities are much less tied to physical places. Scholars commonly cite social media, self-employment, and telecommuting as evidence of this trend. ${ }^{6}$ In Sprawling Places (2008), David Kolb argues that places today should be evaluated according to "criteria of linkage and complexity rather than classical 'authenticity' and centered unity". 7 The concept of "community" is now more complex than a pre-war small-town; people can belong to multiple communities be it global, racial, demographic, political etc.

While it is true that identity is less tied to real places, this does not mean that greater access to a physical 'public realm' would not enrich it. A public realm could encourage more local social interaction, and manifest a sense of community into physically legible places. This does not require a fundamental restructuring of the physical context (as New Urbanists suggest), but rather a creative re-use of existing networks. A physical public realm can be inserted. As previously suggested, this activity could take place in places where residents already tend to congregate - its malls and plazas, and its parks and schools.

In particular, the potential role of shopping malls has been a frequent topic among recent scholars. In her essay "The Vibrant Life of Asian Malls in Silicon 


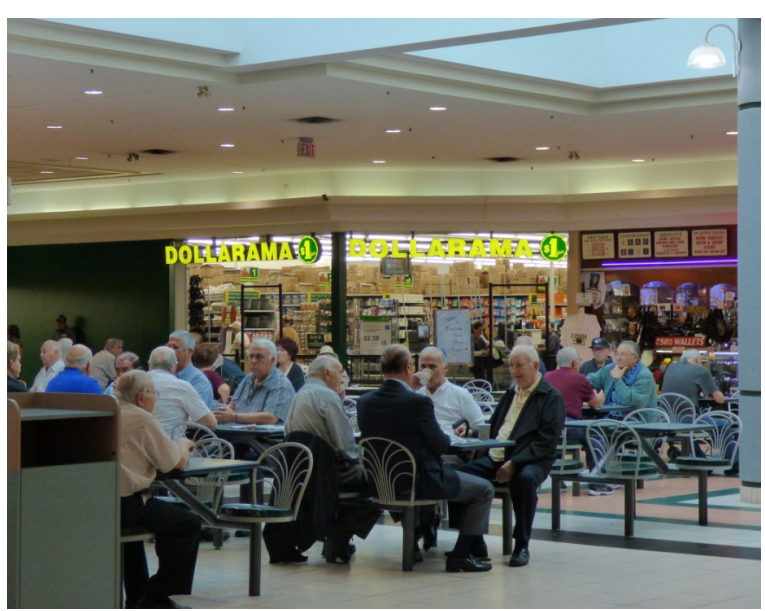

Figure 2: Seniors meeting for coffee at the Rockwood Mall in Mississauga.

Valley", Willow Lung-Amam explores the ways in which shopping malls have taken on a higher diversity of uses, activities, community services and social functions, particularly in ethnic enclaves. ${ }^{8}$ In addition, the National Endowment for the Arts published Sprawl and Public Space: Redressing the Mall (2002): a collection of essays which seek to better engage the role of the shopping mall as public space. ${ }^{9}$ This research suggests that Victor Gruen's vision for the central core could be within reach. In many ways malls are already serving as public nodes. (Figure 2) Unfortunately, in the same way that the physical landscape suburbia does not make its culture legible, the current physical environment of the shopping mall does not support engaging exterior public spaces or visible landmarks.

Thus, a transformation of architecture could strengthen its role as an urban place.

This process of reclaiming malls as gathering places, is consistent with Mississauga's designation of potential 'community nodes', at centrally located commercial sites. (Figure 3) The Rathwood/ Applewood community node is dominated by the site of Rockwood Mall. Suburban cities are recognizing that in order to support higher order transit systems, walkable distances to amenities, and a greater variety of household sizes and demographics, land-use density must be increased. The question is: how much?

In his essay "Density in Communities, or the Most important factor in Building Urbanity" (1990) Eduardo Lozano asserts:

"Density is the critical variable in determining urbanity because of its locational effects. Density determines the accessibility of people to people, of people to work, of people to services and recreation; in short, it allows urban relationships to flourish. "10

At the same time, Lozano takes issue that there is an huge disparity between
8 Willow Lung-Amam, "The Vibrant Life of Asian Malls in Silicon Valley" in Making Suburbia:New Histories of Everyday America, ed. John Archer, Paul J. P. Sandul, and Katherine Solomonson (Minneapolis: University of Minnesota Press, 2015)

9 David Smiley, Sprawl and Public Space Redressing the Mall (Washington, D.C.: National Endowment for the Arts, 2002)

10 Eduardo Lozano, " "Density in Communities, or the Most important factor in Building Urbanity" from Community Design and the Culture of Cities" 1990. In The Urban Design Reader, ed. Michael Larice and Elizabeth Macdonald (London: Routledge, 2007), 316 
11 Eduardo Lozano, " "Density in Communities, or the Most important factor in Building Urbanity" from Community Design and the Culture of Cities" 1990. In The Urban Design Reader, ed. Michael Larice and Elizabeth Macdonald (London: Routledge, 2007), 322

\section{2 lbid, 313}

13 Research conducted by the City of Mississauga indicated that Top 8 Words that Best Describe

Mississauga were: Growing, Family-Friendly, Safe, Culturally Rich, Neighbourhood Feel, Welcoming, Balanced Lifestyle, Community-oriented

City of Mississauga, Our Future Mississauga: Growing Our Brand (City of Mississauga, February 26, 2014), 29

14 City of Mississauga, "Introduction: 1.1 Background", Mississauga Official Plan (City of Mississauga, updated August 11, 2015),

15 Paul Lewis, Marc Tsurumaki, and David J. Lewis. Lewis. Tsurumaki. Lewis: Opportunistic Architecture (Chicago: Graham Foundation for Advanced Studies in the Fine Arts, 2008), 100

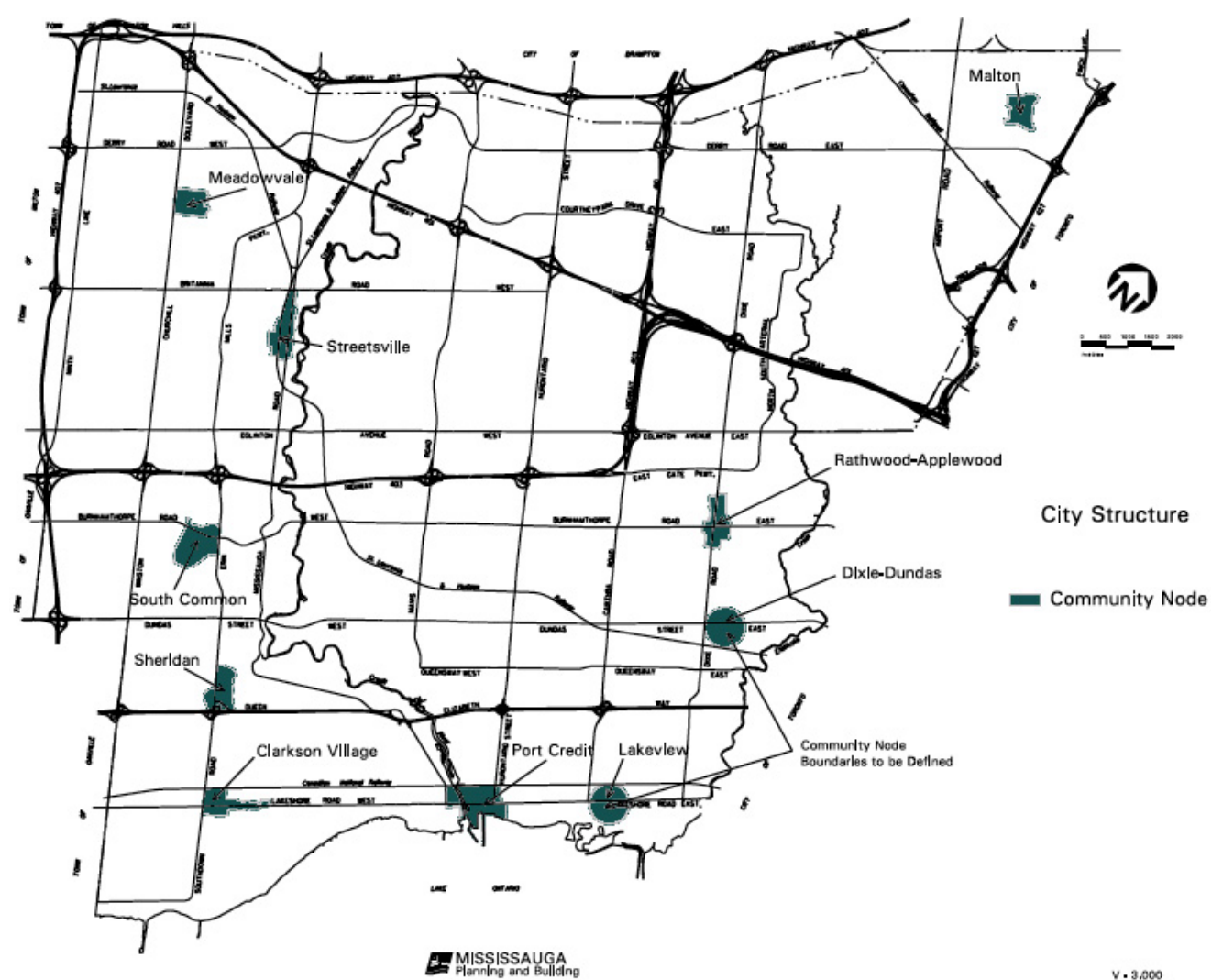

Figure 3: Locations of designated 'community nodes' in the Mississauga Official Plan (updated March 11, 2016)

over-urban density and too-low density of conventional suburban development, stating:

"Millions of people experience daily the rather traumatic shift from a sub-urban environment to an over-urban one, and vise versa, in the belief that one extreme is a cure for the other."11

Thus, Lozano advocates for a better balance in community-oriented environments. ${ }^{12}$ A more evenly distributed density across suburbs could also alleviate some pressure off of major cities.

As urbanists have suggested for decades, increased density is an inevitable consequence of rising populations, and the growing environmental concern over fossilfuel supported automobiles. The question 
then, is how increased densities can be accommodated without radically altering the qualities of suburbia which suburban residents value, such as the comfort of the private realm, a relatively low density 'neighbourhood feel'13, and access to nature. For example, within the introduction to the Mississauga Official Plan, it is stated that, "Many areas, such as existing stable residential Neighbourhoods, will experience little change in the future." ${ }^{14}$ This suggests that the city intends to only intensify density in specific potential areas, and not disturb this single-family home fabric. It would seem that interventions within these new urban cores should aim to provide a transition between the existing low density, landscape-dominated, private condition, and that of a denser, public realm.

This theory will be demonstrated in this thesis through the proposed redevelopment of the central 'community node' of Rathwood/Applewood, discussed further in Part 4.

\section{CASE STUDY:}

"NEW SUBURBANISM" - LTL ARCHITECTS [LEWIS, TSURUMAKI, AND LEWIS]

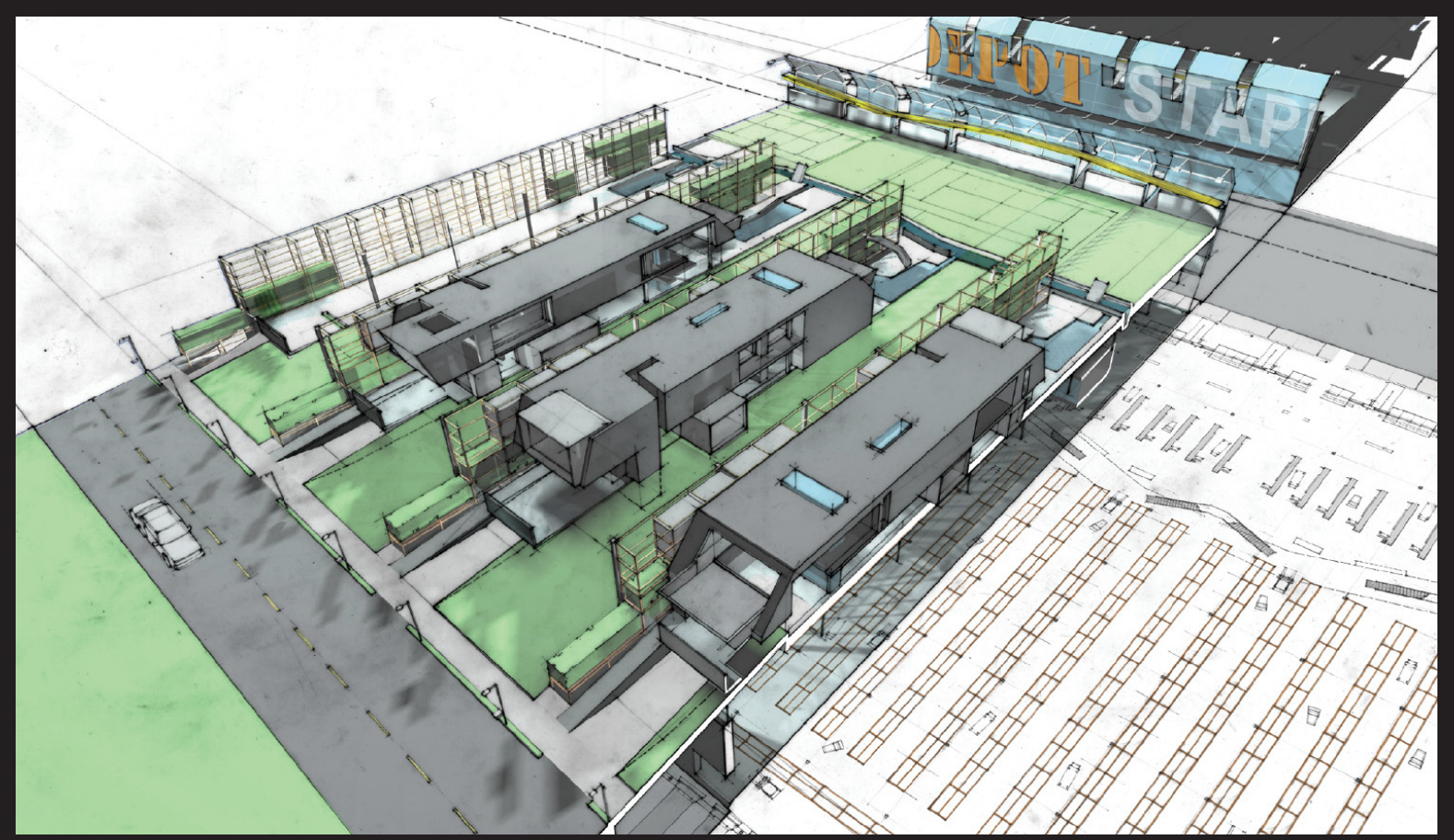

Figure 4: Image of "New Suburbanism" from LTL Architects

This speculative project acknowledges and utilizes the programs of suburbia. The designers have reconceptualized the Big Box store by using it as a plane for residential volumes and sustainable landscapes above. The architects explain:

"In this hybrid of house and store, the identities of both are maintained, but in an altered form-now cross-wired to produce unanticipated social and spatial relationships through their mutual influence. In New Suburbanism, the logic of suburbia is exploited, wasteful redundancies are resolved, and new sectional matings are established in continued pursuit of the American Dream. "15 - LTL Architects 


\section{PART 4: A CASE FOR INTERVENTION}

EXISTING CONDITIONS OF A TYPICAL POSTWAR SUBURB 


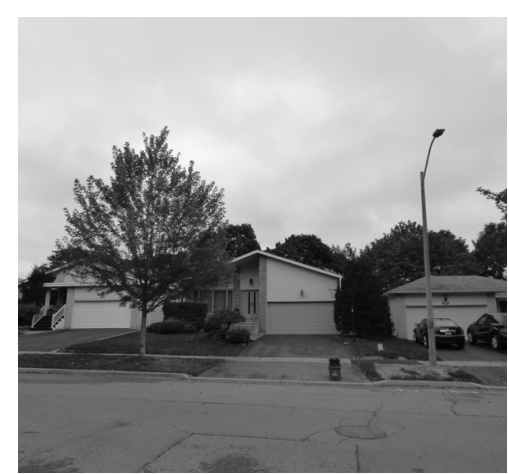

detached single-family home

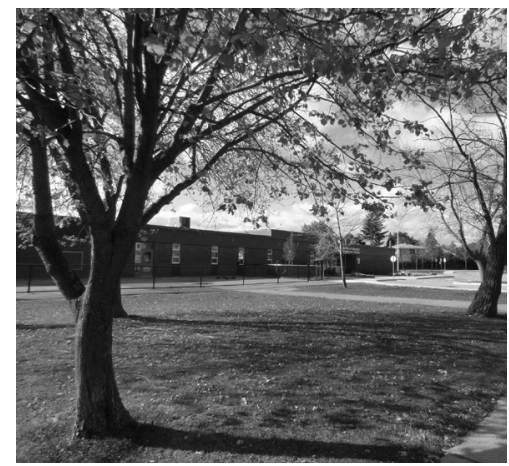

school

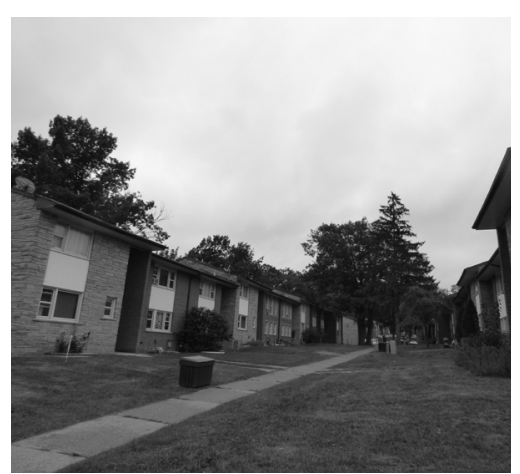

townhouses

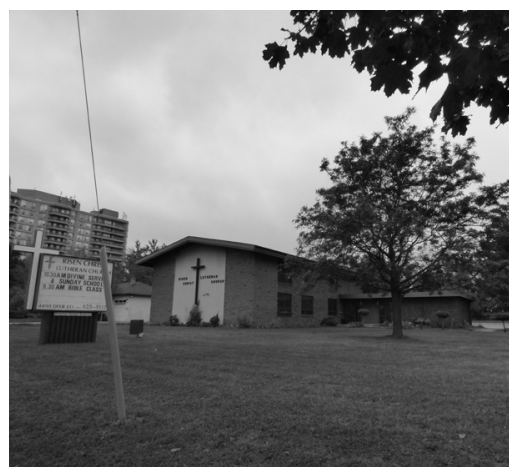

church

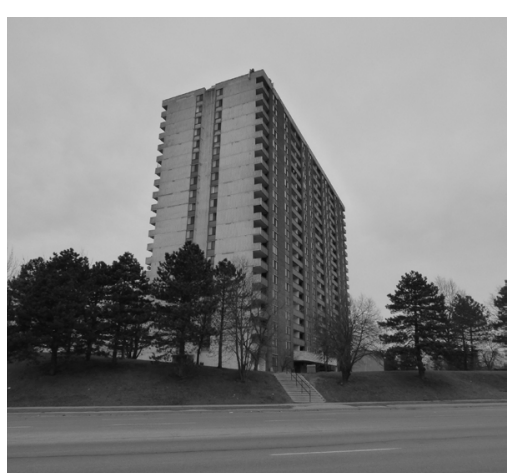

high-rise residential tower

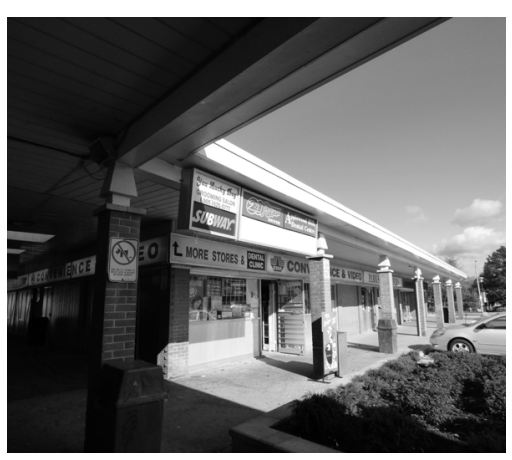

commercial plaza

Figure 1: Existing typologies in Rathwood/Applewood

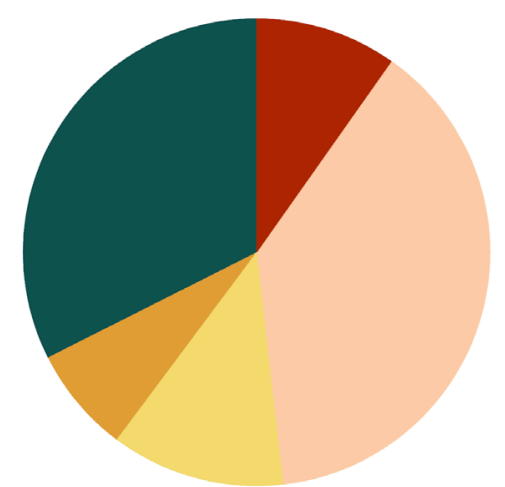

DETACHED HOUSE

SEMI-DETACHED HOUSE

TOWNHOUSE

APARTMENT (HIGH-RISE)

口 APARTMENT (LOW-RISE)

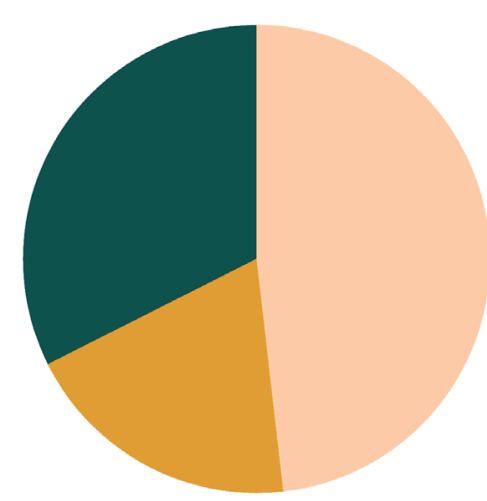

DETACHED HOUSE

SEMI-DETACHED HOUSE TOWNHOUSE

APARTMENTS

\subsection{GENERAL CHARACTERISTICS}

The focus area of Rathwood/ Applewood in Mississauga possesses a set of characteristics that are typical of postwar Canadian suburban regions. The area was developed between 1959 and 1980. ${ }^{1}$

As of the 2011 census, the existing population was $59,825^{2}$, at a residential density of 54.3 persons per hectare. ${ }^{3}$ This is achieved through a combination of detached single-family homes, townhouses, and high-rise residential towers (a total of 21,500 dwellings). Although the landscape appears to be dominated by sprawling residential streets of singlefamily homes, the most common dwelling type is apartments. (Figures 1 and 2) These residential typologies, along with commercial and institutional buildings, are physically separated from one another by large expanses of landscape and surface parking lots.

The suburb's planning was designed primarily for automobile circulation. This is evident in its large open spaces, the curved arrangement of the residential streets, and arterial roads which are commonly six lanes wide. (Figure 3)

Figure 2: Proportion of dwelling types in Rathwood/Applewood 


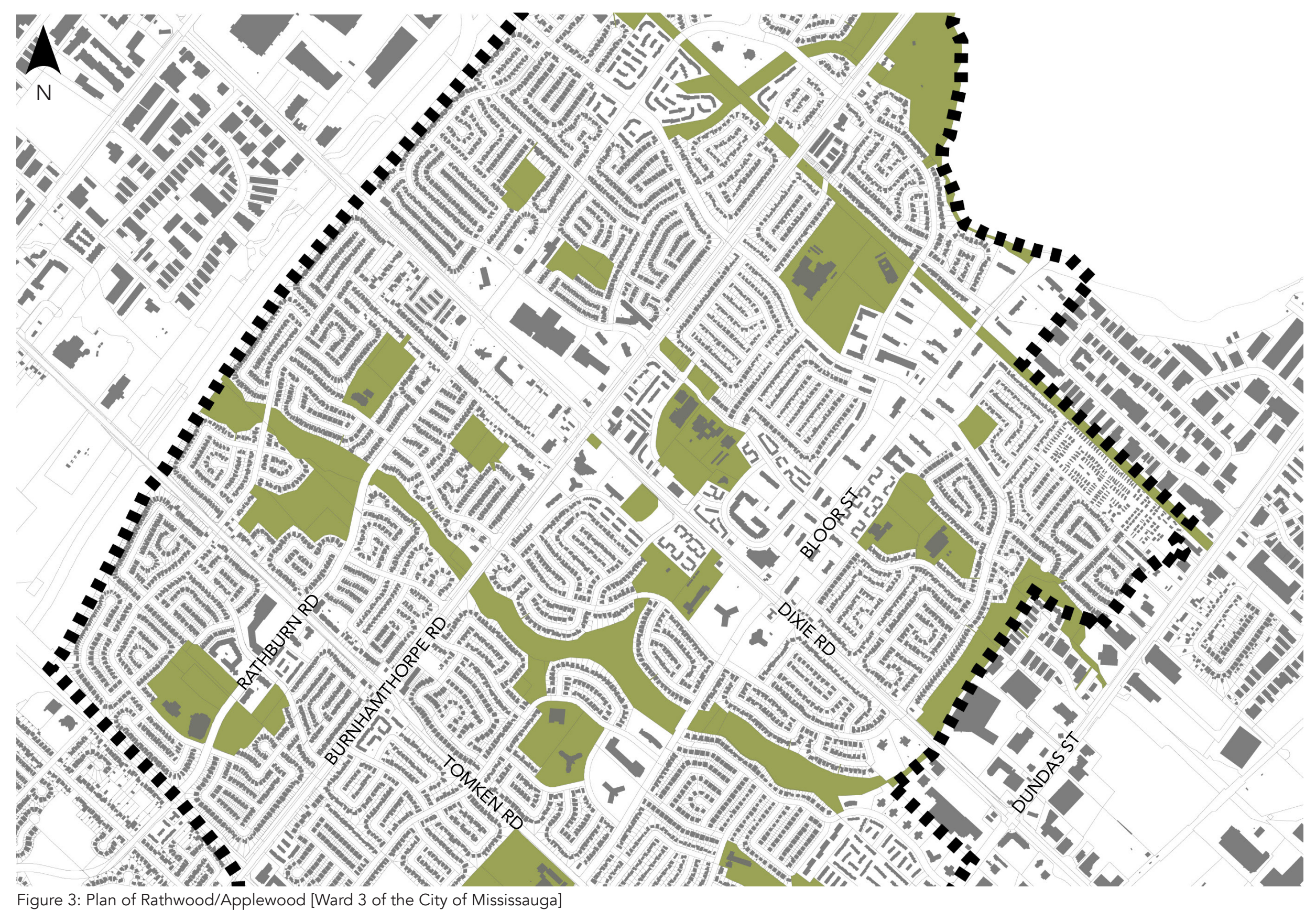


1 The first subdivision in this area "Applewood Heights", was built by Gordon S. Shipp and Son construction in 1959. Information from Kathleen A. Hicks, "Part 4: 1951-2000" in Dixie: Orchards to Industry (Mississauga: Friends of the Mississauga Library System, 2006)

2 City Of Mississauga Planning And Building Department. Census Results Ward 3 Profile (City of Mississauga, June 2014)

3 Estimation by author based on ward area and 2011 census data.

4 City of Mississauga, "Chapter 14 - Community nodes," Mississauga Official Plan - Part 3 (City of Mississauga, March 11, 2016)

5 City of Mississauga, "Chapter 4: Vision"

Mississauga Official Plan, Part 2 (City of Mississauga, August 11, 2015), 9

6 City of Mississauga, "Rathwood / Applewood Community Node" in Focus on Mississauga 2012: Atlas of the Downtown, Major Nodes and Community Nodes ( City of Mississauga, 2012)

\subsection{PRE-INTERVENTION ANALYSIS}

In its effort to densify existing neighbourhoods, the Mississauga Official Plan (updated August 2015), has designated a series of potential 'community nodes' which would be developed to support a higher density of both residential units and workplaces. ${ }^{4}$ These nodes are intended to encourage a 'multi-modal city', where its residents are less reliant on personal automobiles. The Official Plan states:

"Mississauga will integrate land use and transportation planning and sustainable design so that new development is directed to locations that support existing and planned transit and active transportation facilities. "5

The community node for the Rathwood/ Applewood area is located at Dixie and Burnhamthorpe Roads. The existing density of the community node is 76.8 persons per hectare, and 24.2 jobs per hectare (1480 residential units and 1200 employed workers (including home businesses) within 49.5 hectares). ${ }^{6}$

The existing land use indicates large and distinct parcels, with little mixed-use activity. (Figure 8 ) The character area is largely dominated by the existing site of the Rockwood Mall. This site will be the subject of the thesis intervention.

\section{POTENTIAL OPPORTUNITIES}

The central location of the Rockwood Mall site, and its alignment with transit supported arterial roads, suggest its potential to serve as a primary urban node and transit hub for the surrounding neighbourhoods. Its close proximity to lowrise residential streets will ensure walkability from the surrounding homes. It could add a significant increase in density to the neighbourhood and become a catalyst for development along Dixie Rd. This activity could support higher-order transit, such as light-rail transit along this spine. (Figure 9)

The selected site could be considered a case study for a number of appropriate sites in Rathwood/Applewood and other typical postwar suburbs. 


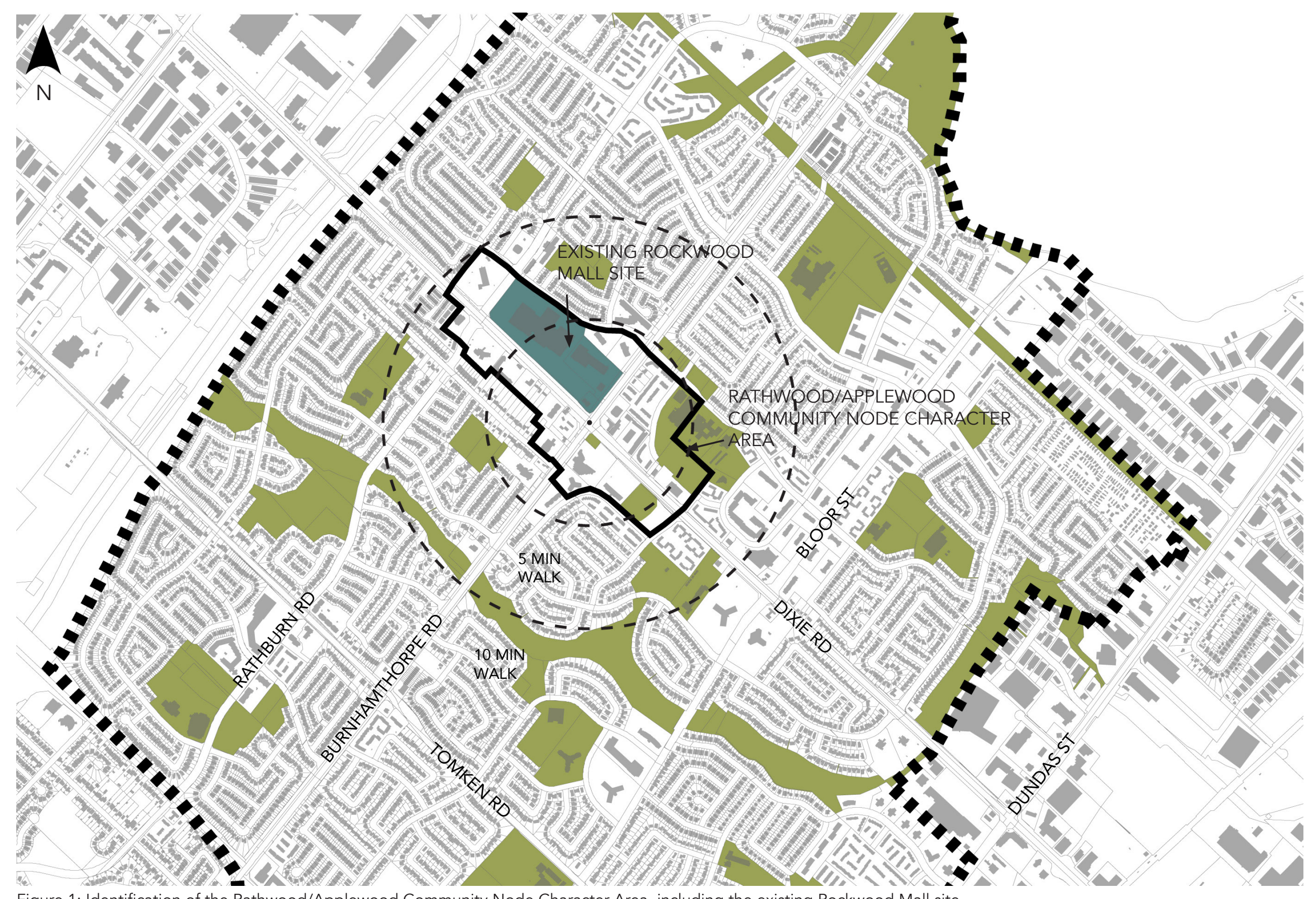

Figure 1: Identification of the Rathwood/Applewood Community Node Character Area, including the existing Rockwood Mall site. 


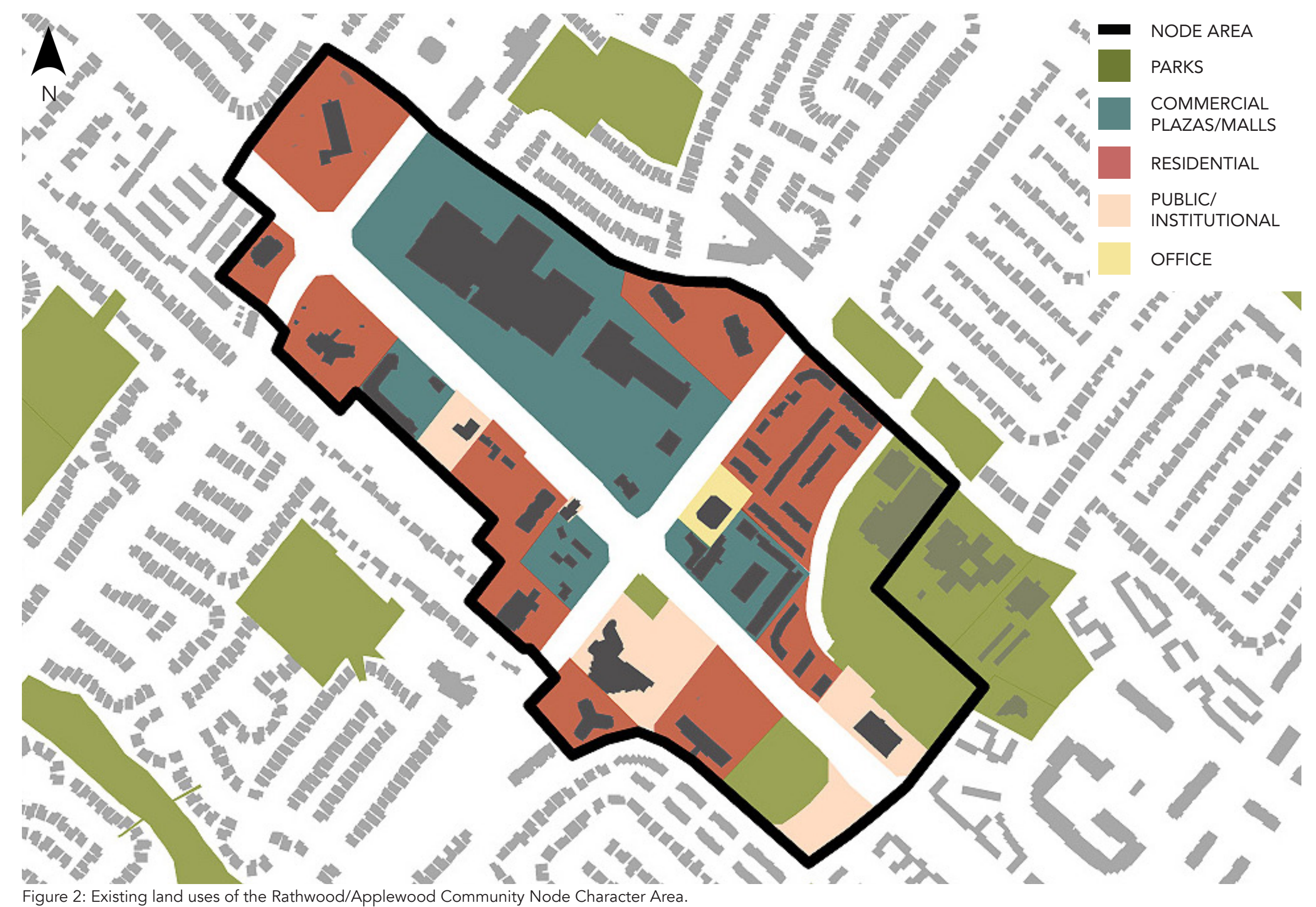




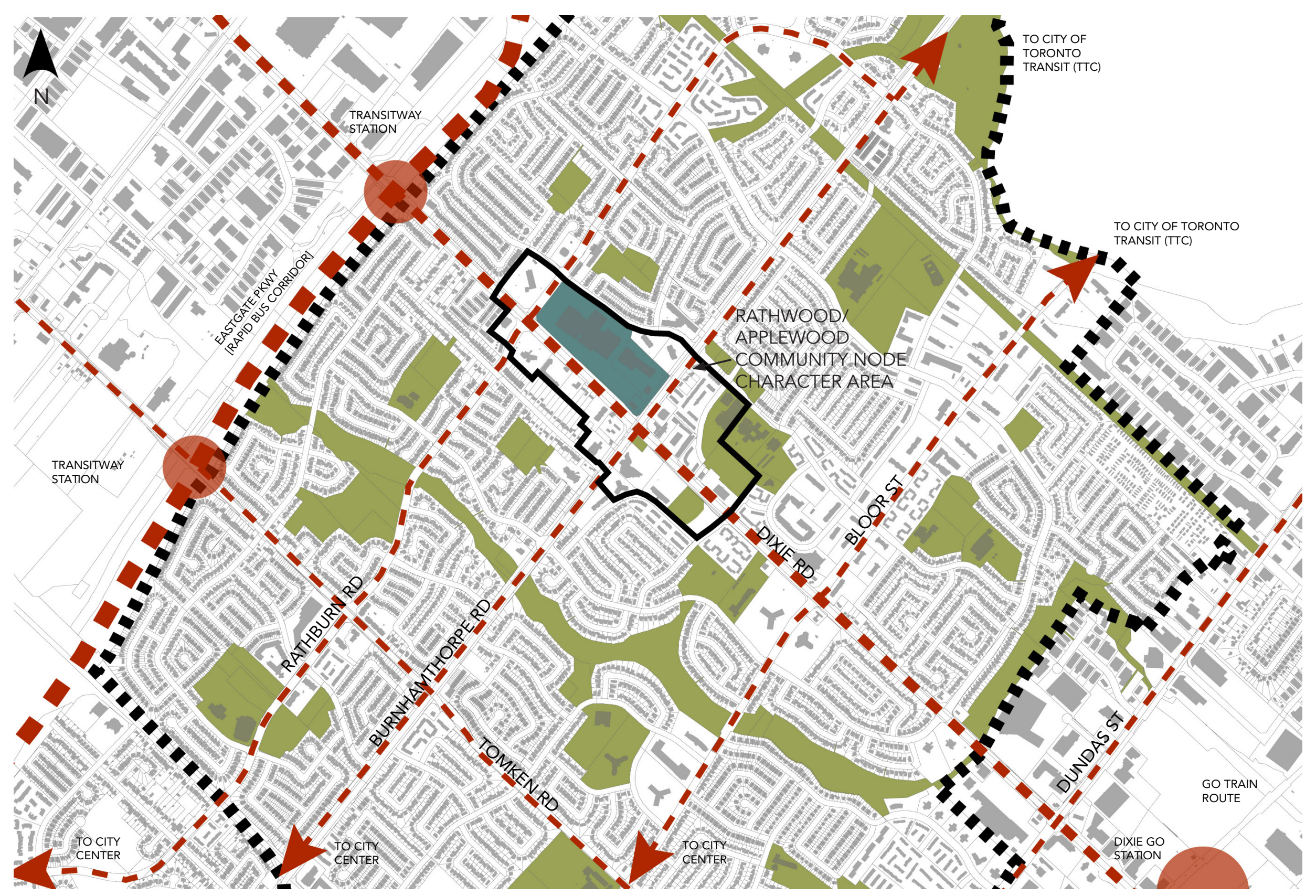

Figure 3: Identification of existing bus routes through the Rathwood/Applewood Area. The 'community node' could serve as a transit hub, which could support future higherorder transit, and connect residents to the Mississauga City Centre, Toronto Transit (TTC), GO Transit and the new Mississauga Rapid Bus 'Transitway.' 


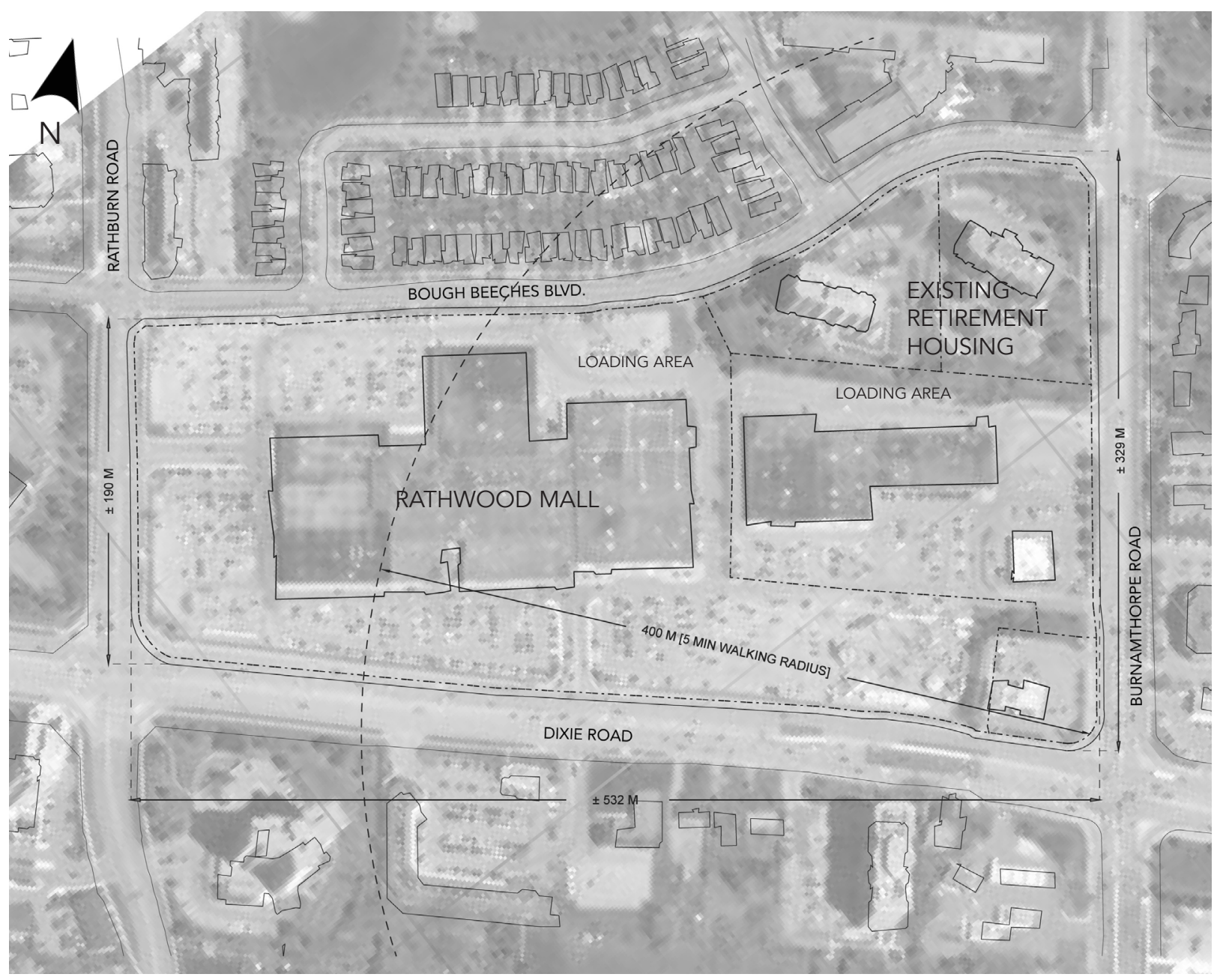

Figure 4: Existing Rockwood Mall Site Plan

\section{CHALLENGES OF EXISTING SITE}

The challenges of this site are consistent with general issues of modernist environments. As is typical of conventional shopping malls, Rockwood Mall is designed for the motorist, not the pedestrian. The mall and strip plaza are organized with a significant setback from arterial roads, in order to provide ample space for surface parking lots. The low-rise, horizontal form of the mall and strip plaza gives little sense of enclosure or hierarchy. This organization also fails to address the surrounding context - neither the low-rise residential homes to the north, or the high-rise residential towers to the east and south.

It takes around 7 minutes to walk from Burnhamthorpe Road to Rathburn Road. For this reason, there is a bus stop at each road, and a traffic light intersection in between. This is an enormous amount of space to be devoted to a single land use, with no through streets. Overall, there is a lack visual and programmatic variety. 


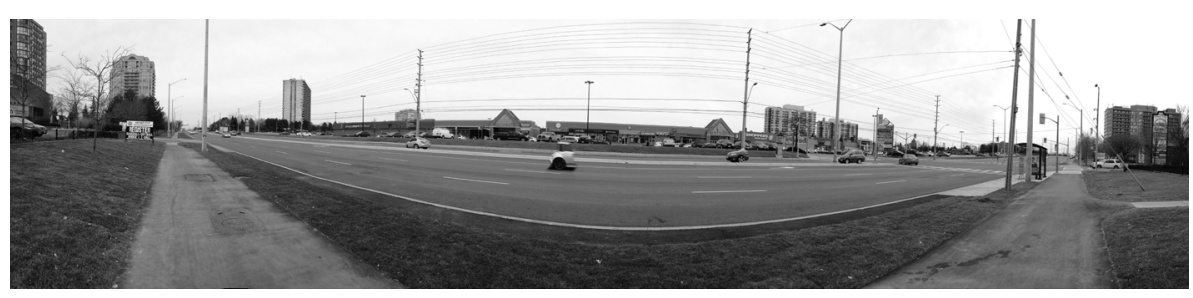

Figure 5: Dixie Road [looking north toward Rockwood Mall]

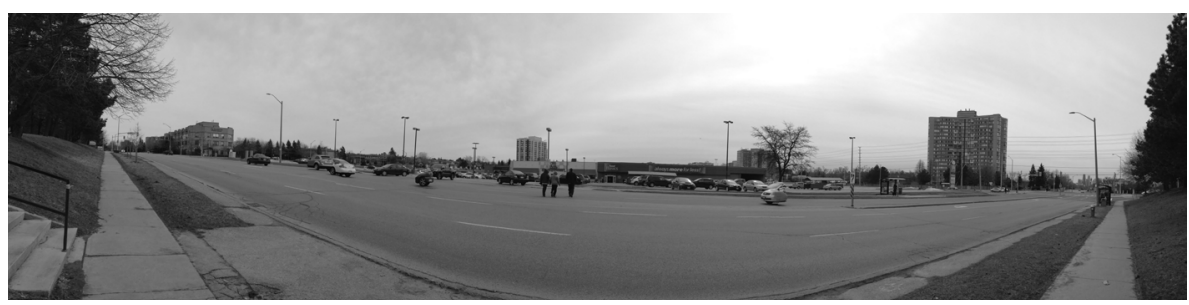

Figure 7: Rathburn Road [looking east toward Rockwood Mall]

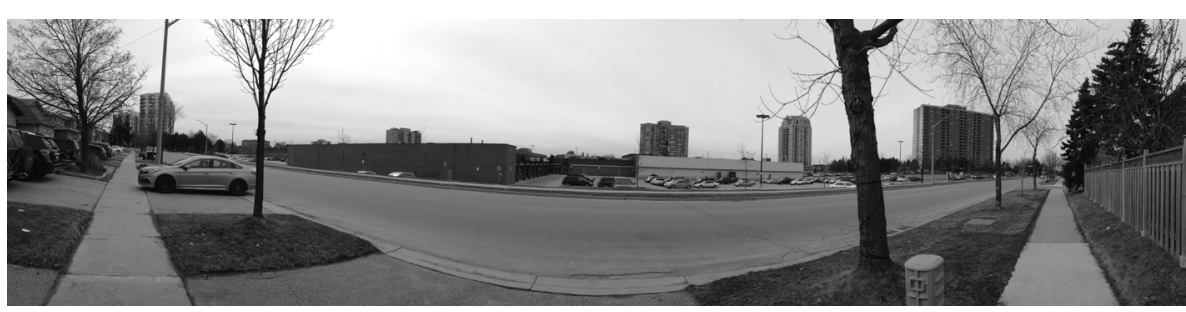

Figure 9: Bough Beeches Boulevard [looking south toward Rockwood Mall]

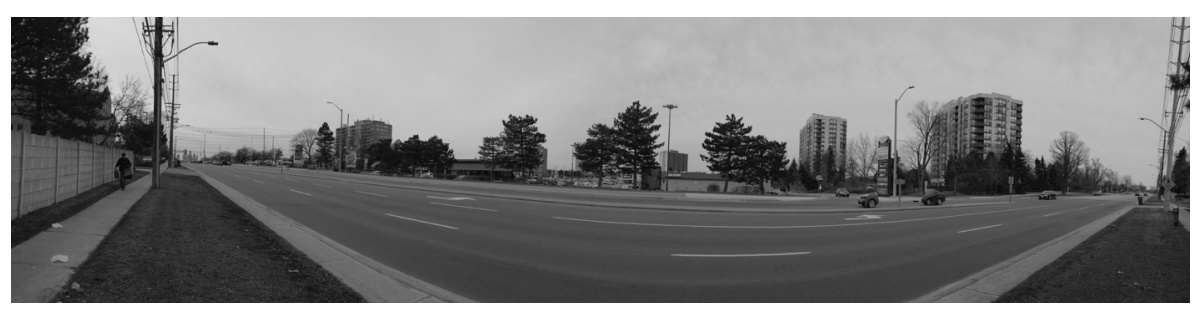

Figure 11: Burnhamthorpe Road [looking east toward Rockwood Mall]

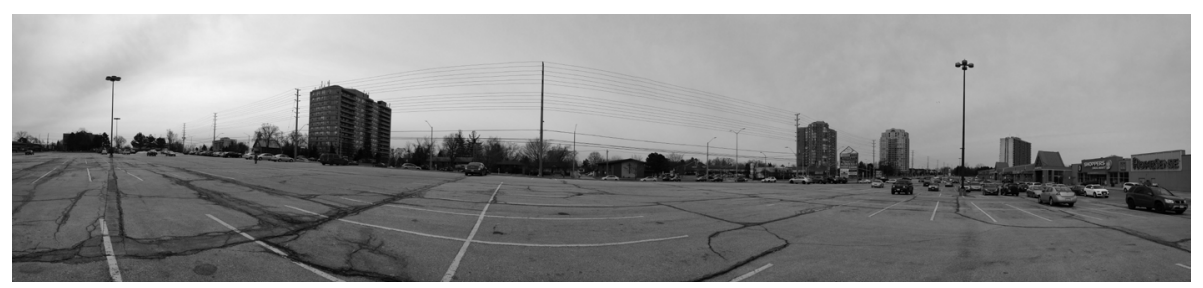

Figure 6: Dixie Road [looking south]

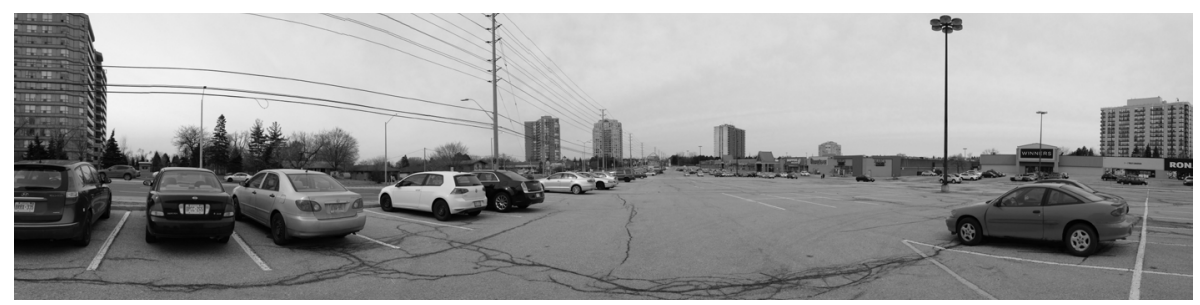

Figure 8: Inside mall parking lot [looking west toward Rathburn Road]

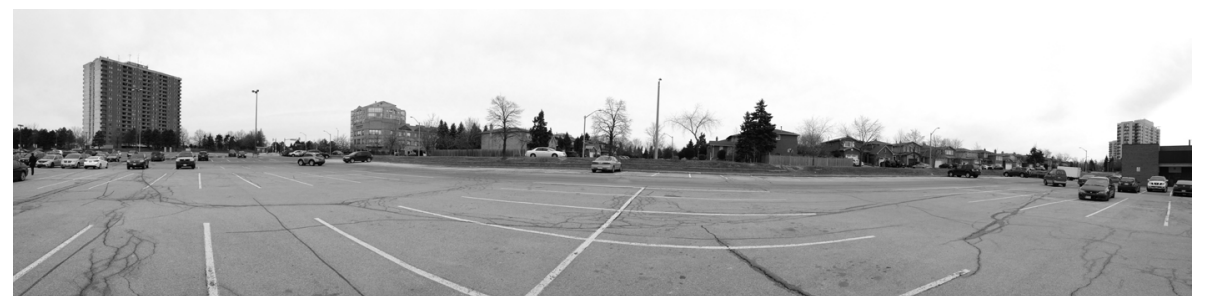

Figure 10: Bough Beeches Boulevard [Looking north toward Residential streets]

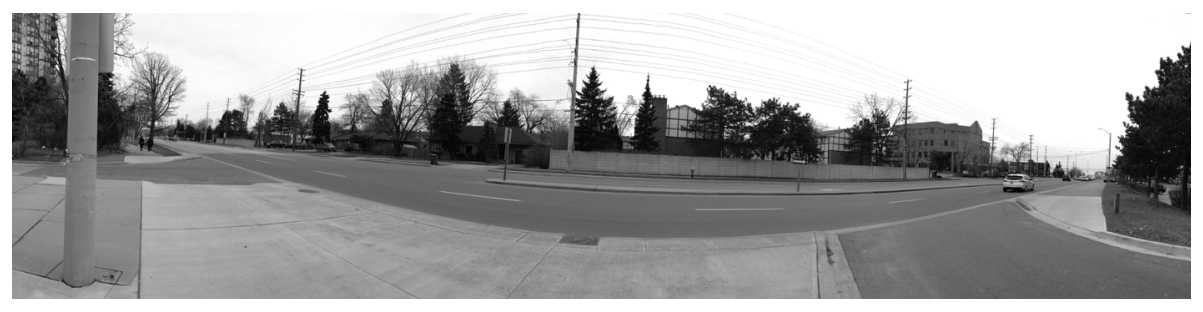

Figure 12: Burnhamthorpe Road [Looking west] 
4

$N$
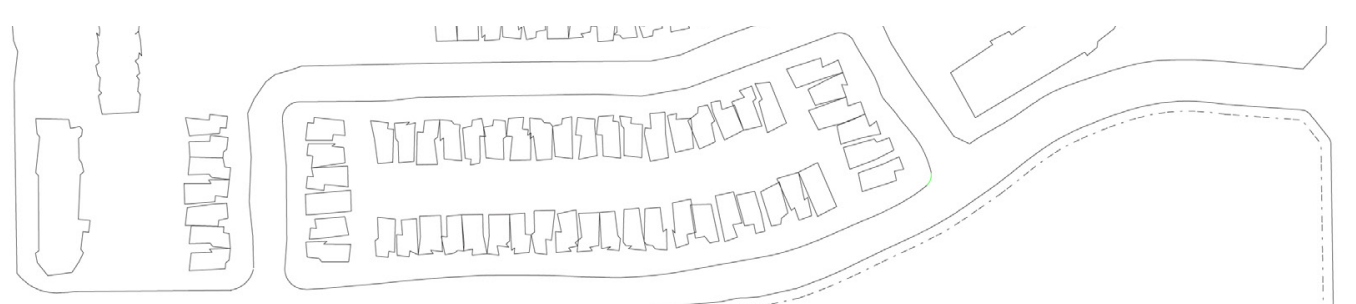

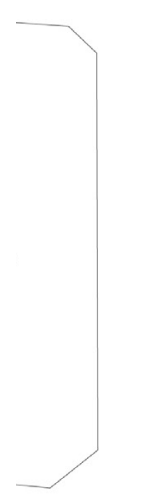
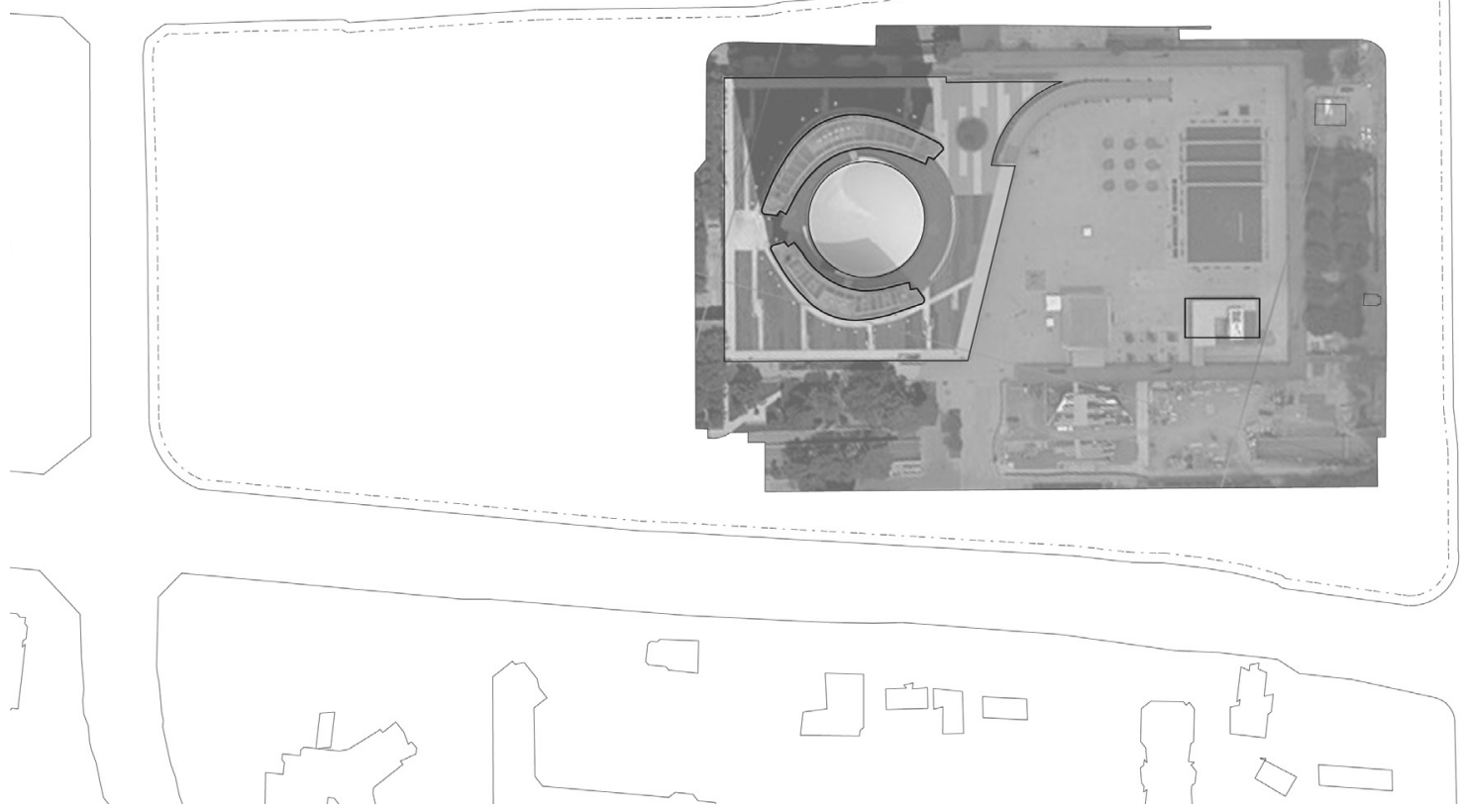

Figure 13 (above): Scale of site as relative to Toronto City Hall and Nathan Phillips Square Figure 14 (below): Context of Toronto City Hall and Nathan Phillips Square

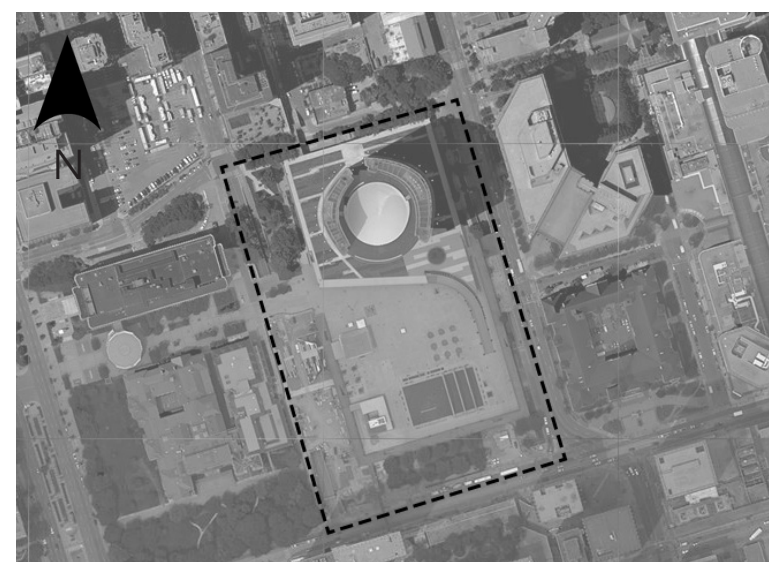

The site which includes the Rockwood Mall and adjacent retirement towers amounts to approximately 12.5 hectares (31 acres). Thus, the scale of the site is comparable to large urban redevelopment sites such as the Toronto City Hall and Nathan Phillips Square (Figure 13), as well as a section of the Regent Park Redevelopment Plan. (Figure 15) Nathan Phillips Square is a highly flexible and frequently-used urban space. The Regent Park Redevelopment Plan has carefully considered the pedestrian through its small blocks and relatively narrow volumes.

While these comparisons are useful to visualize the scale and potential of the site, the context of a postwar suburb is quite different from the high density urban environment of Toronto. In both of these cases, the redevelopment was inserted into an already dense built fabric. They are supported by context. In the typical suburban environment such as Rockwood Mall, the challenge is to create the context. 


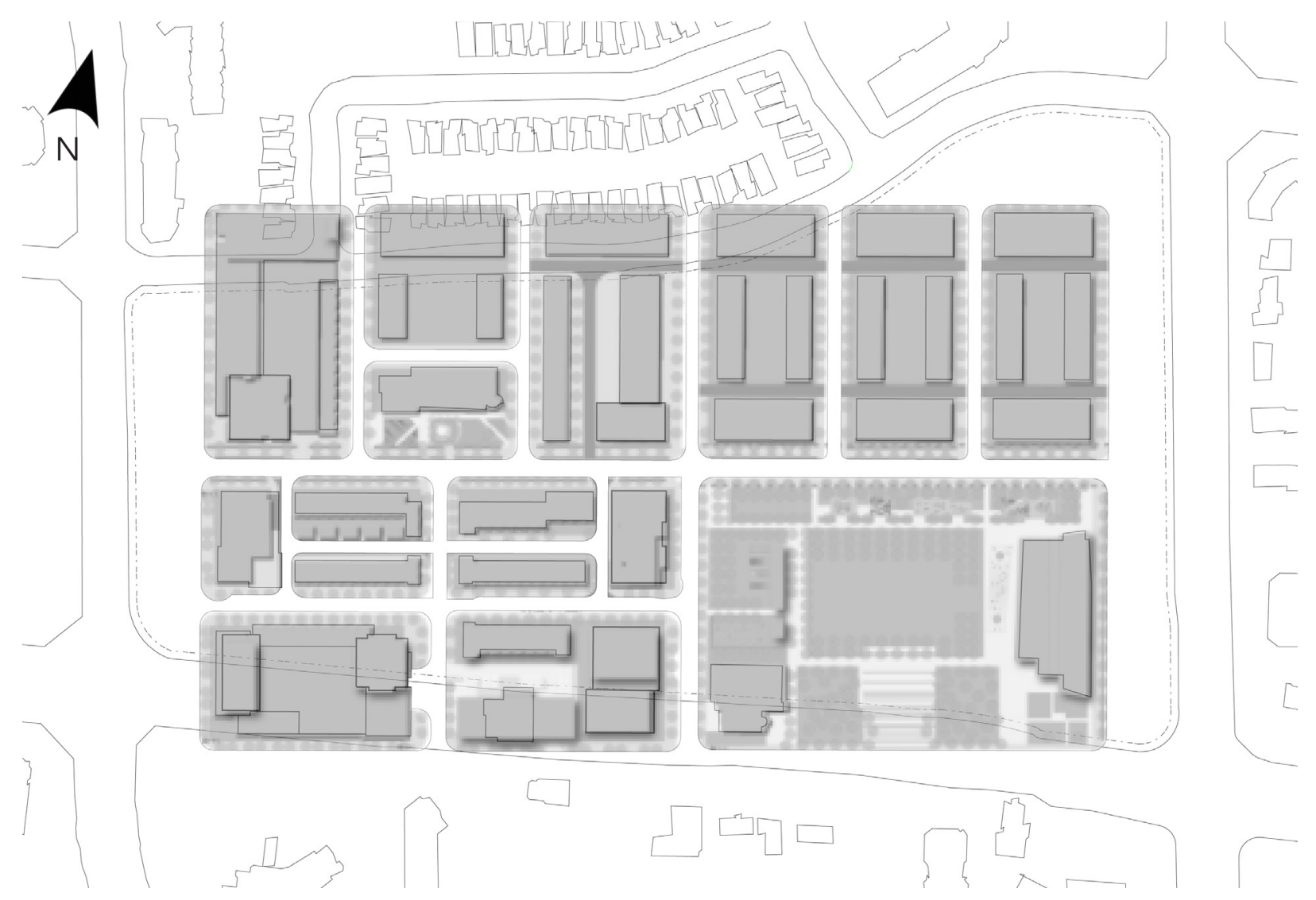

Figure 15 (above): Scale of site as relative to a section of the Regent Park Redevelopment Plan Figure 16 (below): Context of the Regent Park Redevelopment Plan

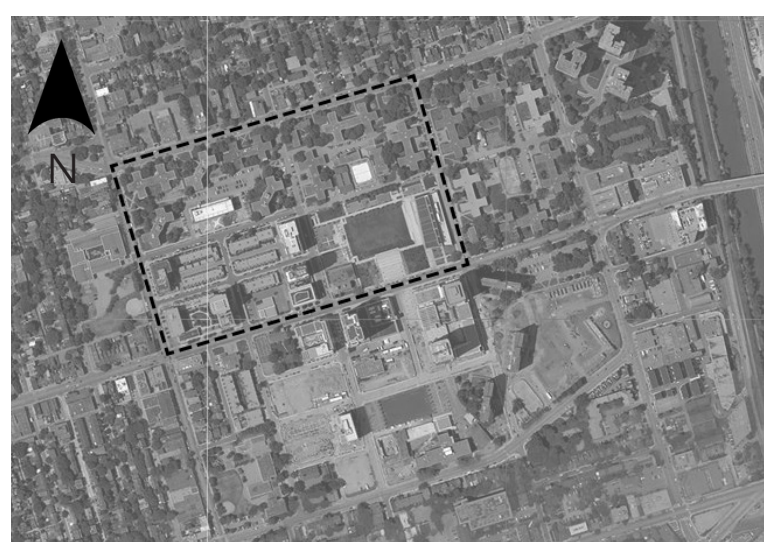


1 Rem Koolhaas, "The Generic City" in S, M, L, XL (Rotterdam: 010 Publ., 1995), 1249-1250

2 lbid, 1260

3 Aaron Betsky, and Adam Eeuwens. False Flat: Why Dutch Design Is so Good (London: Phaidon, 2004), 30

4 Robert Docter, "Post-war Town Planning in Its Midlife Crisis." In The Modern City Revisited, edited by Thomas Deckker (London: Spon, 2000), 199

\section{$5 \mathrm{lbid}$}

6 Aaron Betsky, and Adam Eeuwens. False Flat: Why Dutch Design Is so Good (London: Phaidon, 2004), 36

\section{CHAPTER 5.1 \\ THE GENERIC CITY: \\ LEARNING FROM THE NETHERLANDS}

Postwar suburbs are deemed "artificial" places, unlike historic cities, they did not grow seemingly 'organically' over hundreds of years. For this reason, many urban professionals disregard their potential. In contrast, Dutch architect Rem Koolhaas believes that there is opportunity in artificial places.

\section{Koolhaas's article "The Generic} City," from S, M, L, XL (1994), has been frequently misread as a general acceptance that generic modernist architecture meets the needs of a capitalist market and that we are helpless to change this. On the contrary, this work indicates that Koolhaas had more faith in architectural expression than most architects at the time. Much like Archigram's work of the 1960s, Koolhaas advocates that there is opportunity in 'newness'.

\section{In "The Generic City" Koolhaas} suggests that society puts too much pressure on the historic city to be "the most important place," but ironically also the place that is constantly being modernized. He explains, "it paradoxically has to be, at the same time, the most old and the most new, the most fixed and the most dynamic.... Yet this adaptation has to be inconspicuous, remaining historic to the outside viewer. Meanwhile the architecture that exists outside the core is "liberated from the captivity of the center, from the straitjacket of identity... it is the city without history"1

Koolhaas asserts that architecture without history is not necessarily boring. He suggests that modernism has evolved beyond functionalism to become art, stating:

"The Generic City proves him [Mies Van der Rohe] wrong: it is more daring. Architects have taken up the challenge Mies abandoned, to the point where it is now hard to find a box." 2

\section{Koolhaas suggests that a response to} modern program and market conditions does not necessitate architectural uniformity. It is true that new architecture within historic cities is encouraged to be 'respectful' or 'sympathetic' to the existing context, and is often relegated to generic architectural expression. In the suburbs, there is much more freedom for architectural experimentation and space to define new paradigms. If anything, Koolhaas is arguing that it is the historic city 
that is perhaps the "Generic" one.

The "city without history," that Koolhaas describes is best personified by the city of Rotterdam in the Netherlands. The historic city was heavily bombed during WWII, leaving eighty percent of the central city in ruins by the end of the war. ${ }^{3}$ As a result of an extensive postwar rebuilding program, Rotterdam is characterized by a distinctive postwar modern character. In his essay "Post-war town planning in its mid-life crisis" (2000) Rob Docter explains:

"The devastation of Rotterdam created an interesting socio-cultural phenomenon. The postwar'spirit of redevelopment'found a good breeding ground in Rotterdam, a city that had always had a modern, progressive character...other cities tried to reference the historic. In Rotterdam the new society and the new city required an image that was futuristic, optimistic - the modern face of architecture. ${ }^{\prime 4}$

Despite being created out of postwar modernism, Rotterdam's built fabric is not boring, repetitive or isolating. Rather than rebuild in styles of the past (or build international style boxes), Dutch architects saw this situation as an opportunity to create new landmarks and new spatial conditions; a legacy of innovation that

\section{CASE STUDY:}

"LIJNBANN SHOPPING CENTRE" J.H. VAN DEN BROEK AND JACOB BAKEMA

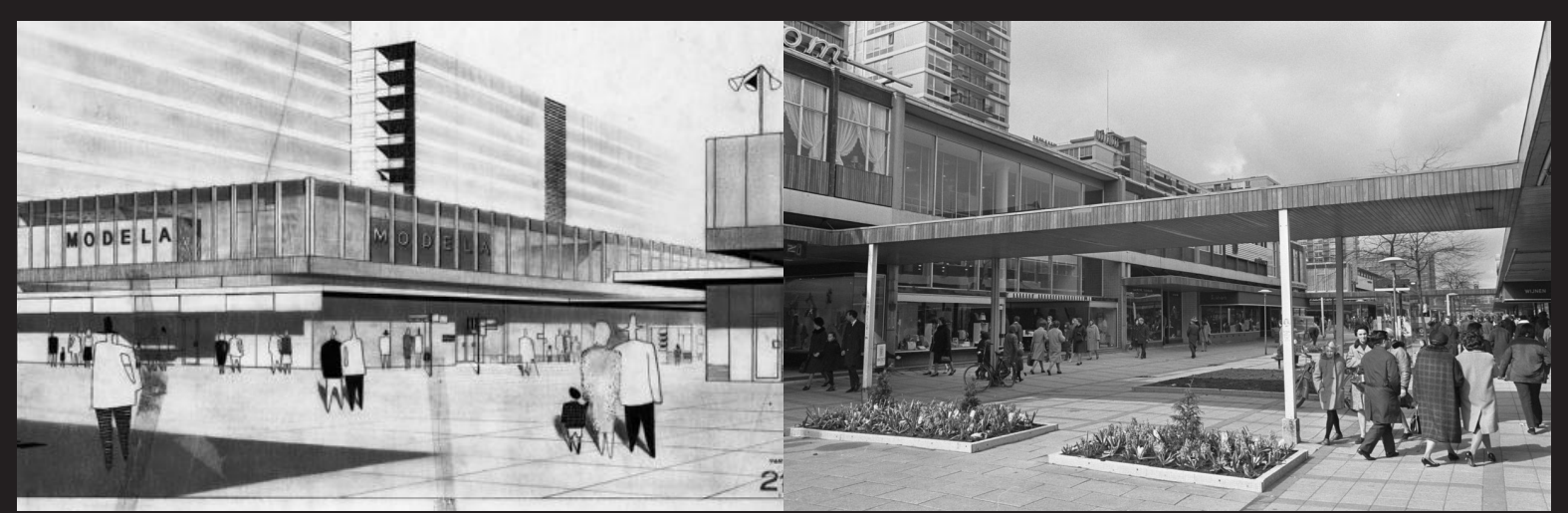

Figure 1: Sketch by Van den Broek \& Bakema

Figure 2: Lijnbann, Rotterdam (March 30, 1967)

The 1953 'Lijnbann' shopping centre, by Van den Broek and Bakema, was a direct result of the critiques of orthodox modern planning within CIAM modernism (as discussed in Chapter 2.3). The outdoor pedestrian shopping mall presented a different version of modernity than the functional modernist "towers in the park" model. It showed that modernism could be human scaled and pedestrian oriented, and could support public space. ${ }^{5}$ In False Flat: Why Dutch Design is So Good (2004), Aaron Betsky explains:

"As a new core they planned the Lijnbann, a pedestrian district made up of a tartan weave of glass-fronted stores surmounted by offices and homes and interspersed with tall apartment slabs set in parks. Experts from all over the world came to admire this model of rational and integrated shopping, business, and living core for a modern city," 6

To this day, the Lijnbann continues to be well used and vibrant. Although it originally lacked in visible landmarks, it has continually supported new projects along its spine. 
7 Robert Docter, "Post-war Town Planning in Its Midlife Crisis." In The Modern City Revisited, edited by Thomas Deckker (London: Spon, 2000), 199

8 Matthew Cousins, Design Quality in New Housing: Learning from the Netherlands (Abingdon, Oxon: Taylor \& Francis, 2009), 16

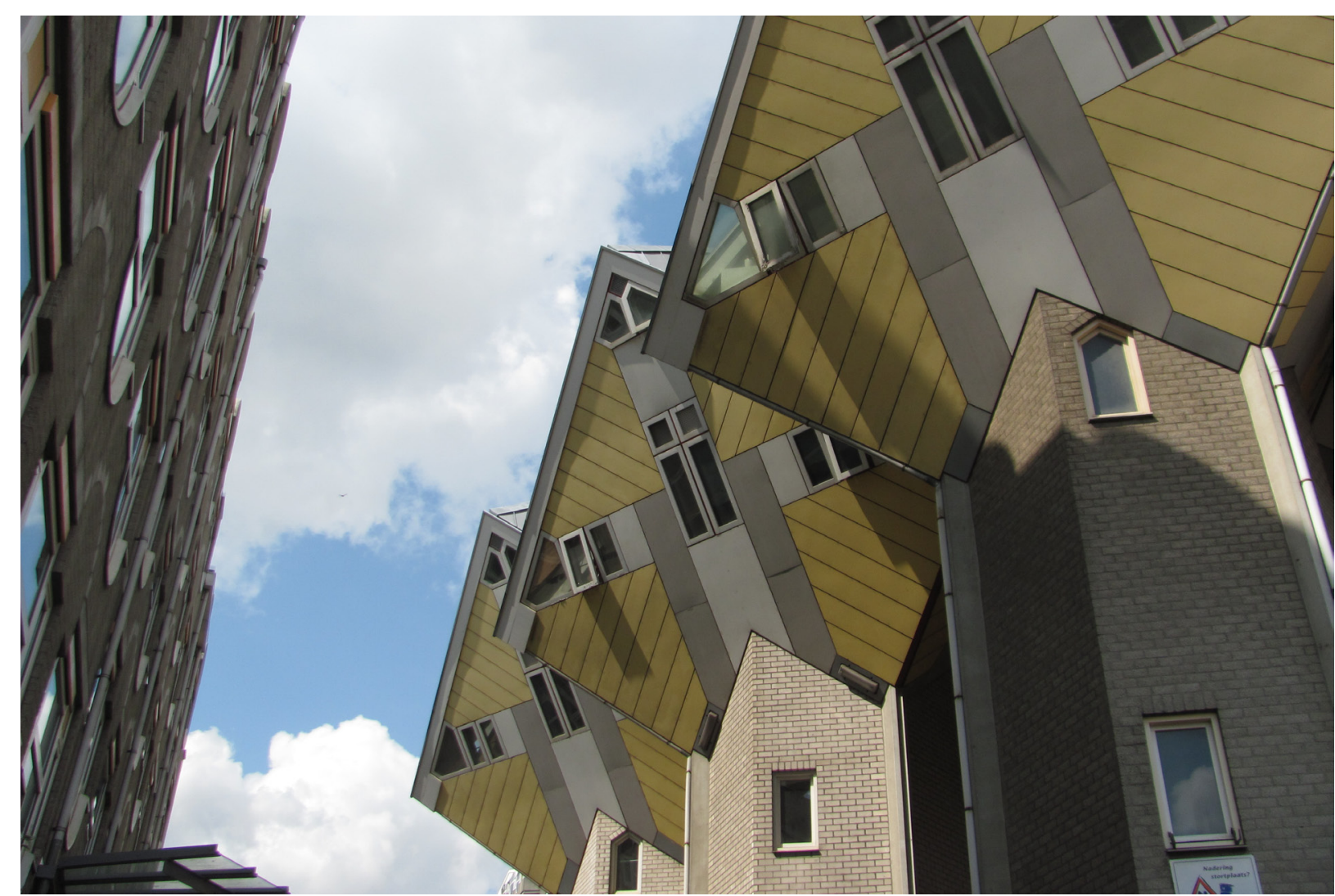

Figure 3: Rotterdam's "Cube houses" (1977) by Piet Blom

continues to this day.

Despite being a "city with no history" Rotterdam has developed a strong sense of place as a result of a lack of historic fabric. If this resurgence had never happened, Rotterdam would look the same as any other Dutch city. Rob Docter explains,

"It is remarkable how the urban districts that came into being in the 1950s and 1960s are appreciated in Rotterdam in the same way other cities cherish their medieval town centers. ${ }^{17}$

\section{This spirit of innovation for} new places has continued to this day. The Netherlands was the first country to introduce "a national architectural policy." 8 The 'Vinex' policy was created as a supplement for the Fourth National 


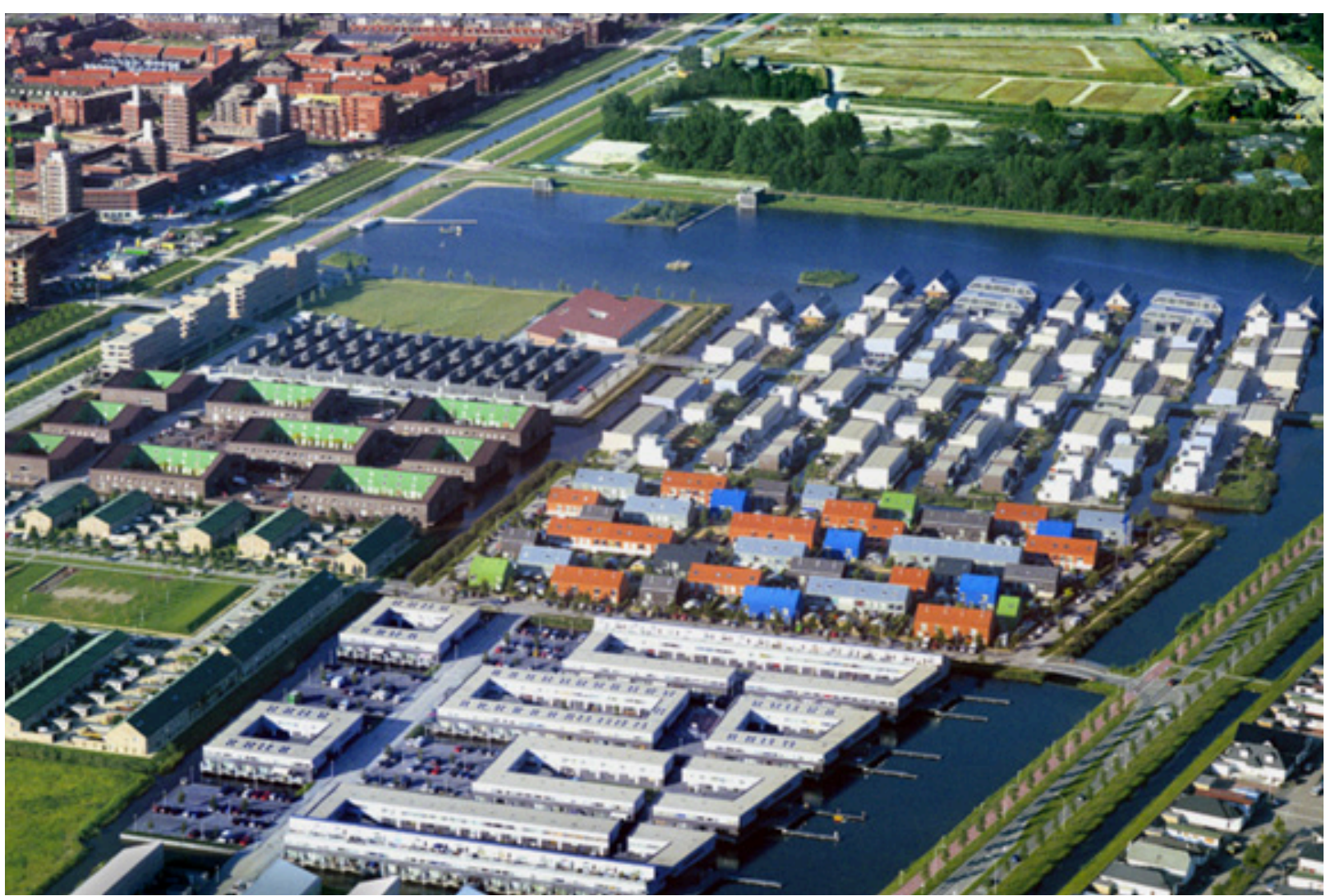

Figures 4: Ypenburg, a Vinex suburb of The Hague, The Netherlands

Policy of 1990. Vinex is a abbreviation of the Dutch term 'Vierde Nota Extrai' (which translates into Fourth Memorandum on Spatial Planning Extra). ${ }^{9}$ This policy was created to guide the development of new cities and suburbs, as required to meet the housing needs of its growing population. In Design Quality in New Housing: Learning from the Netherlands (2009), Matthew Cousins explains:
9 Matthew Cousins, Design Quality in New Housing: Learning from the Netherlands (Abingdon, Oxon: Taylor \& Francis, 2009), 17

\section{$10 \mathrm{lbid}$}

"The housing proposals were ambitious; over a ten-year period from 1995 to 2005 one million houses were to be constructed, close to existing city centres and with good public transport connections... There are over 90 new Vinex housing projects in the Netherlands, of which around 50 new towns were built in the Ranstad area between Utrecht and Amsterdam, increasing in total numbers of dwellings by 7 per cent." 10 
11 For more more detailed evaluation of the Dutch Vinex policy and its resultant projects, refer to Design Quality in New Housing: Learning from the Netherlands, Matthew Cousins

12 "Almere Masterplan." OMA. Accessed February 19, 2016. http://oma.eu/projects/almere-masterplan.

13 Architectureguide.nl. Accessed February 19, 2016 http://www.architectureguide.nl/project/list_projects_ of_city/cit_id/12/prj_id/1553.

$14 \mathrm{lbid}$

15 lbid
Design quality has been a major priority for the Vinex program. Dutch designers continue to be critical throughout this process, striving for greater variety, durability, and better environmental quality. ${ }^{11}$ Increasingly, Vinex suburbs are being built with (or are in the process of building) their own 'city centres.'

The City of Almere is an entirely new city, located east of Amsterdam. Over its twenty year history, it has grown steadily to reach a current population of 100,000 residents. To anticipate its future status as a prominent medium-sized city, Almere has demonstrated a strong commitment to design quality. ${ }^{12}$ In 1994, a short-listed competition was held to development a master plan for the center of Almere. Rem Koolhaas's Office for Metropolitan Architecture (OMA) was awarded the project. ${ }^{13}$ OMA chose to organize the given programme into a series of megastructures: with "a business centre near the station and a mix of cultural amenities, shops and housing along the water."14 Within the framework set up by OMA, individual projects have been executed by multiple international architects including: Claus \& Kaan, René van Zuuk, de Architekten Cie, Sanaa, and Will Alsop. ${ }^{15}$ Almere (along with similar developments) demonstrates that an urban "a sense of place" is not exclusively achievable through incremental development over hundreds of years, but that it can be designed. This is possible when design innovation and variety is given high priority.

Koolhaas's words and the new cities that manifest them, challenge the assumption that modern places must be subservient to historic ones. A 'city without history' can still be a valuable place. In the same way, new developments in North American suburbs can be seen as opportunities to create urban places which are culturally complex and visually engaging. 

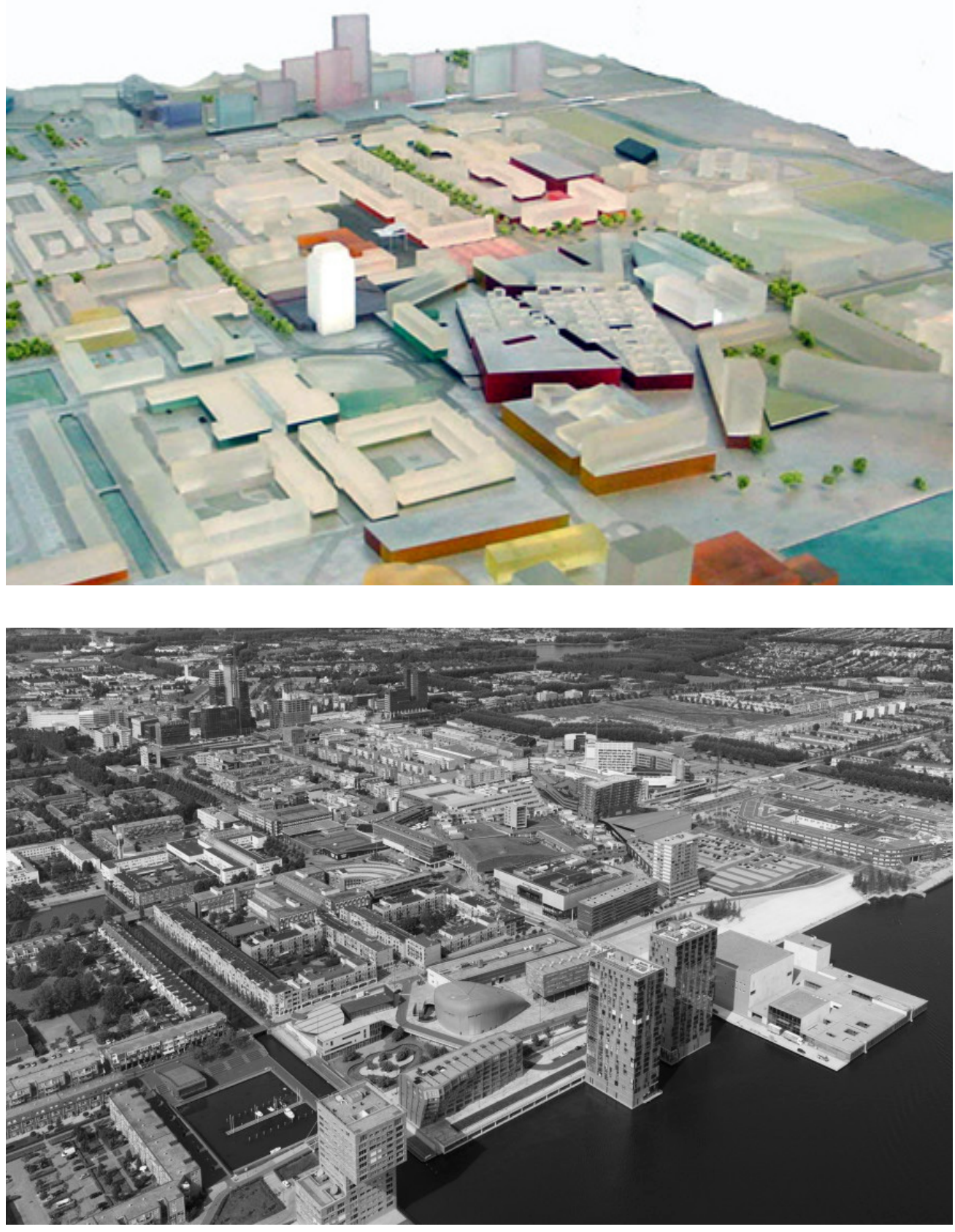

Figure 6: Recent aerial photo of Almere City Centre 
1 Aaron Betsky, and Adam Eeuwens. False Flat: Why Dutch Design Is so Good (London: Phaidon, 2004), 354

\section{2 lbid, 10}

3 Maurizio Sabini, "Pragmatic Modernism: The Dutch Laboratory on Architecture, Landscape and the City," in Getting Real: Design Ethos Now: Abstracts. ed. Renee Cheng and Patrick J. Tripeny (Washington, DC: Association of Collegiate Schools of Architecture, 2006), 425

4 Bernard Hulsman, Double Dutch: Architecture in the Netherlands since 1985 (Rotterdam: Nai010 Publishers, 2014), 10

5 Thomas Deckker, "Part 3 Introduction: The Decline of Modernism" In The Modern City Revisited, ed.

Thomas Deckker (London: Spon, 2000), 194

\section{CHAPTER 5.2 \\ THE EMERGENCE OF SUPERMODERISM}

With regards to transforming

modernist environments, designers can take many valuable lessons from the Dutch, who have perfected the practice of expanding and altering the existing landscape, and maintained an especially strong link to modernism. In False Flat: Why is Dutch Design So Good (2004), Aaron Betsky explains:

"In fact, the Dutch have produced a model that other countries can follow. The knowledge that we live in an artificial environment we have collectively created and must collectively use is something that is true everywhere, even in the United States, where an acre a day of open desert is being swallowed by the suburbs of Phoenix....We all need to look in the mirror and map out a better world that we can collectively inhabit." ${ }^{\prime 1}$

Throughout their history, the Dutch have transformed what was essentially a swamp condition in to a complex network of man-made dykes. ${ }^{2}$ As Maurizio Sabini suggests: "[the] Netherlands were almost invented by molding nature: they are a work in progress, a design idea." 3 Their custom of re-inventing and creating new places is one of the reasons that Dutch Architects never lost faith in modernism in the way that North American architects did in the 1980s. In Double Dutch: Architecture in the Netherlands since 1985 (2014) Bernard Hulsman notes:

"Dutch architecture had shown little interest in the fashionable caprices of postmodernism. So the continuity with the heroic Modern Movement of the 1920s remained unbroken. ${ }^{\prime 4}$

Scholars suggest that neo-modernism persisted in The Netherlands until around 1990, when an era of experimental and critical architecture began. Essentially, contemporary Dutch architects have continued the critical discourse on modernism that was initiated in the postwar period (as discussed in Part 2).

There are numerous reasons why modernism has been so pervasive among Dutch architects in the latter part of the twentieth century. Like most European cities, Dutch cities required a great deal of reconstruction after the Second World War. The country adopted modernism completely as the appropriate strategy to achieve this. ${ }^{5}$ However, in The Netherlands, the adoption of modernism was not just 


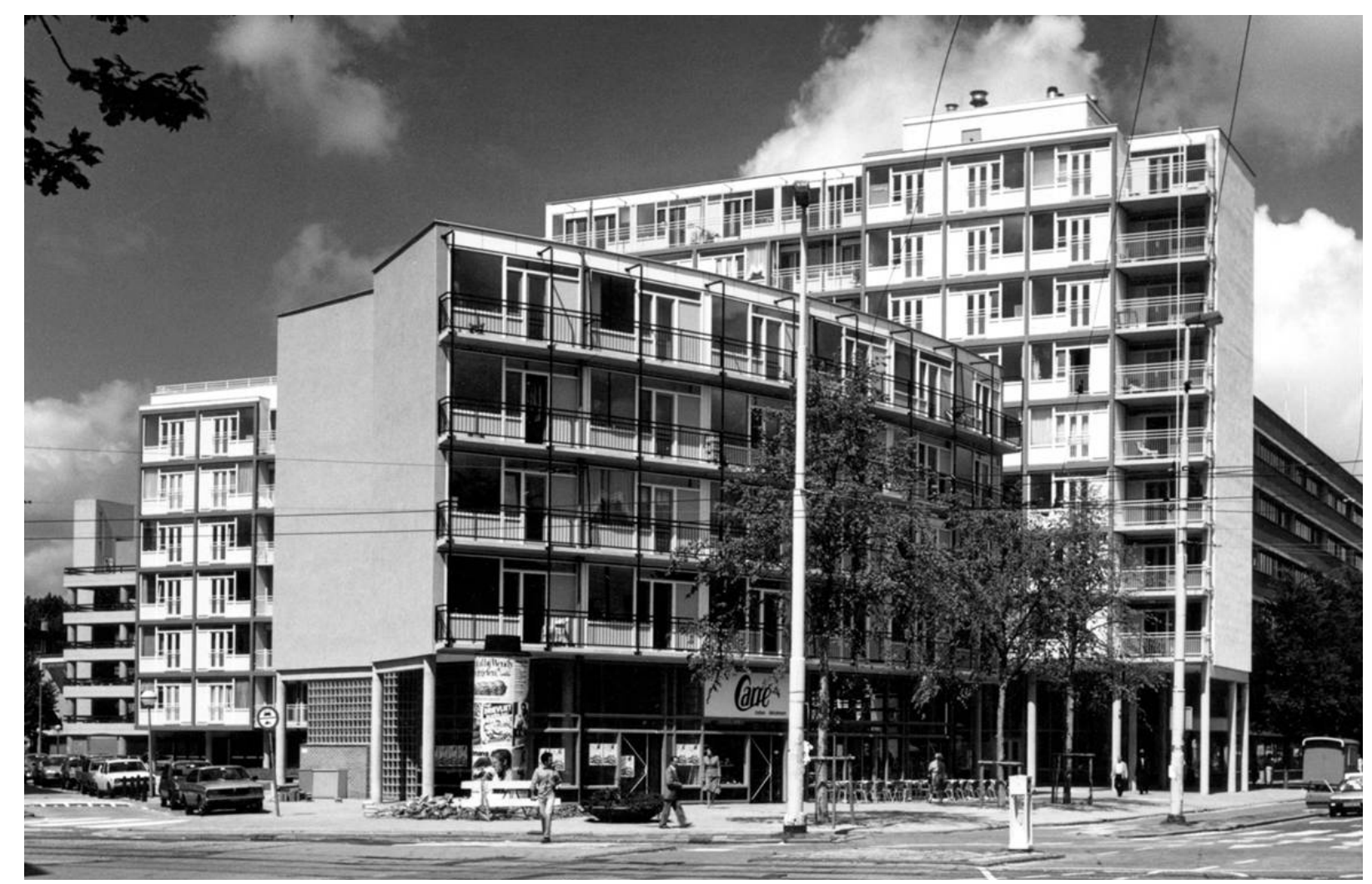

Figure 1: Dutch firm Mecanoo became known for a neo-moderist aesthetic during the 1980s. As seen here in their Kruisplein social housing project in Rotterdam (1981-1985).

an economic necessity, but the 'project' of modern architecture also appealed to their "engineering tradition of environmental transformation."6 This influence was also due in part to the legacy of Dutch Modernist architects and planners such as JJP Oud, Cor van Eesteren, Jacob Bakema and Aldo Van Eyck, who had been progressive leaders in the evolution of modernism during the postwar period. ${ }^{7}$ Many of the younger CIAM members who were critical of functionalist modernism, (and the eventual members of Team 10), were Dutch. This discourse fed directly into the development of "dutch structuralism" which emerged out of mat urbanism strategies. Architect Aldo van Eyck has been deemed "the spiritual father of structuralism." Van Eyck had an enormous influence on the Netherlands' reluctance towards postmodernism. ${ }^{8}$ Architects like Van Eyck felt that postmodernism and neo-
6 Maurizio Sabini, "Pragmatic Modernism: The Dutch Laboratory on Architecture , Landscape and the City, in Getting Real: Design Ethos Now: Abstracts. ed. Renee Cheng and Patrick J. Tripeny (Washington, DC: Association of Collegiate Schools of Architecture 2006), 425

\section{7 lbid}

8 Bernard Hulsman, Double Dutch: Architecture in the Netherlands since 1985 (Rotterdam: Nai010 Publishers, 2014), 15 
9 Bernard Hulsman, Double Dutch: Architecture in the Netherlands since 1985 (Rotterdam: Nai010 Publishers, 2014), 16

\section{$10 \mathrm{lbid}, 30$}

\section{$11 \mathrm{lbid}, 17$}

12 Bart Lootsma, Superdutch: New Architecture in the Netherlands (New York: Princeton Architectural Press, 2000), 16

13 Bernard Hulsman, Double Dutch: Architecture in the Netherlands since 1985 (Rotterdam: Nai010 Publishers, 2014), 30

14 Bart Lootsma, Superdutch: New Architecture in the Netherlands (New York: Princeton Architectural Press, 2000), 17 traditionalism was a 'betrayal of the cause', and even associated it with fascism. ${ }^{9}$ The generation after the Dutch structuralists, practiced an "architecture without dogma", one which drew on the aesthetic without the socialist doctrine. ${ }^{10}$ Until 1990, the tradition of modernist architecture would be systematically passed on to younger generations of architects. This process was later characterized by the term "schoolteacher modernism."11

The pervasiveness of modernism in the Netherlands has also been cultural. For one, The Netherlands has a strong heritage of Calvinism; a sect of Christianity which was formed by the Protestant reformer John Calvin in the $16^{\text {th }}$ century. Generally, Calvinism stresses simplicity and frugality. This tradition pervades into the production of architecture. In SuperDutch: New

Architecture in the Netherlands (2000), Bart Lootsma explains:

"Calvin's admonition continues to lurk in the background, even in the spheres of architecture, fashion and design. The Dutch spend less on clothing than any other European nation. New buildings are expected to cost a fraction of what is budgeted in the rest of Europe. "12
Scholars now associate the end of "schoolteacher modernism" with a 1990 Delft University symposium organized by Rem Koolhaas entitled "How Modern is

Dutch Architecture?." At this symposium Koolhaas expressed concern that Dutch architecture had become 'shockingly' anachronistic'. ${ }^{13}$ He concluded that it had become too reliant on mimicking styles of the past, and was lacking in vitality and innovation. Bart Lootsma explains:

"The participants enthusiastically grappled with the question of how far the Dutch custom of idolizing prewar modernism as a style still bore any relation to the current state of modernity. "14

For some scholars, this event marked the delayed entry of postmodernism to the Netherlands. For others it has been deemed as the beginning of a second wave of modernity. Regardless of the terminology, the result has been a progressive evolution of modernism which better takes into account contemporary realities. Maurizio Sabini explains:

"With an increasingly experimental attitude and intervention-based strategies, Modernity is being experienced in the Netherlands more as an ever-evolving 


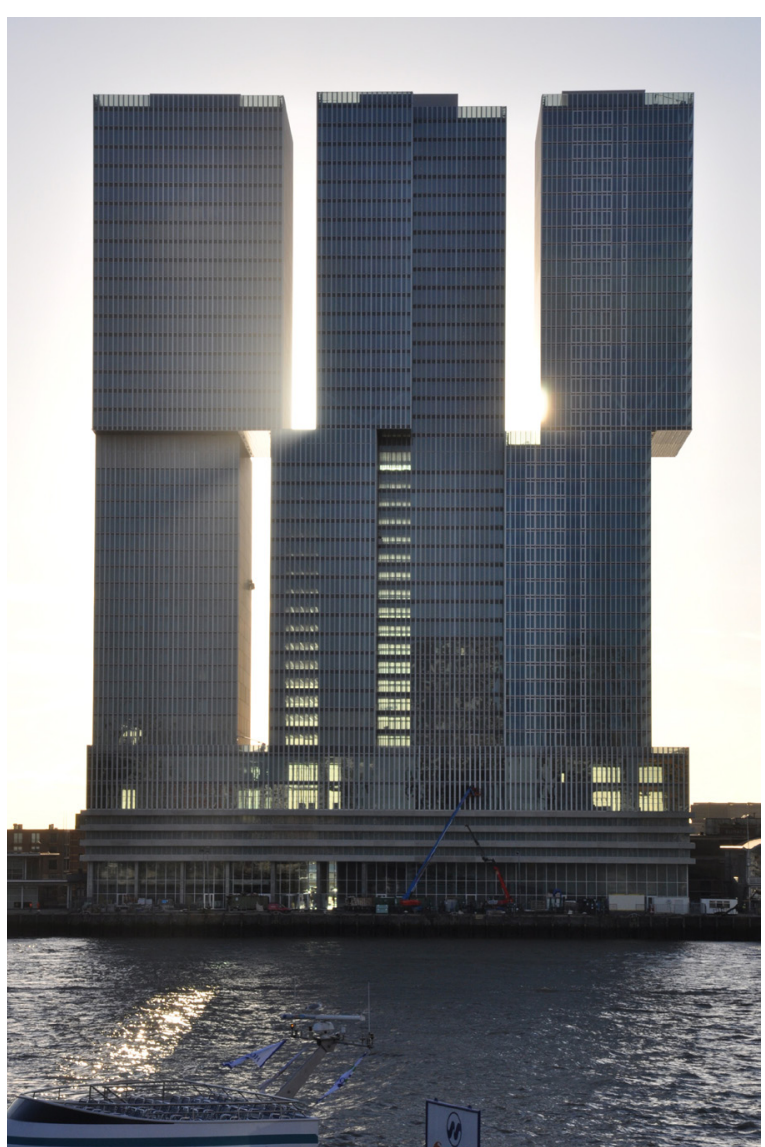

Figure 2: De Rotterdam by OMA (2013)

condition and a continued commitment to innovation, rather than as an aesthetic manifesto for cultural propaganda. "15

In the last 25 years, Dutch architects have become well-known for their response to the so-called "second modernity"; leading to the creation of terms 'supermodernism' or 'superdutch'. The so- called "second modernity" is associated with an increasingly digital and globalized world, similar to the first Modern period's glorification of industrialization. ${ }^{16}$ This phenomenon is not exclusive of The Netherlands. For instance, Germany has been experiencing a similar tradition. ${ }^{17}$ As well, the work of Bjarke Ingels Group (BIG) from Denmark, demonstrates similar principles. However, generally speaking, it has taken root most strongly in the Netherlands. Hulsman suggests that the Dutch are more susceptible to the forces of globalization than other countries due to its extremely open economy and location. ${ }^{18}$

In Supermoderism: Architecture in the age of Globalization (1998). Hans lbelings suggests that supermodernism is a new form of "international style" which is universally applied across the globe. In opposition to this theory, Bernard Hulsman debates that supermodernism does not (as Hans lbelings would suggest) "render concepts like place, context and identity meaningless". ${ }^{19}$ He states:

"On the contrary, globalization, whose context-free architecture is to make the world look the same everywhere, causes many to cry out for their own recognizable place.... Many such digital, hypermobile
15 Maurizio Sabini, "Pragmatic Modernism: The Dutch Laboratory on Architecture, Landscape and the City," in Getting Real: Design Ethos Now Abstracts. ed. Renee Cheng and Patrick J. Tripeny Washington, DC: Association of Collegiate Schools of Architecture, 2006), 425

16 Bernard Hulsman, Double Dutch: Architecture in the Netherlands since 1985 (Rotterdam: Nai010 Publishers, 2014), 65

17 Hans Ibelings, The Artificial Landscape: Contemporary Architecture, Urbanism, and Landscape Architecture in the Netherlands (Rotterdam: NAi Publishers, 2000) 241

18 Bernard Hulsman, Double Dutch: Architecture in the Netherlands since 1985 (Rotterdam: Nai010 Publishers, 2014), 65

19 Bernard Hulsman, Double Dutch: Architecture in the Netherlands since 1985 (Rotterdam: Nai010 Publishers, 2014), 66 
20 Bernard Hulsman, Double Dutch: Architecture in the Netherlands since 1985 (Rotterdam: Nai010 Publishers, 2014), 66 people long for buildings that respond to 'context' provide a 'place' and thereby create a unique identity. " 20

Hulsman asserts that despite this trend of globalization, we still need physical landmarks; in fact we might need them even more. However, this activity need not be tied to any particular style, language or typology of architecture.

\section{Our progressively digital and}

globalized world has encouraged individuals to value innovation and variety. As the Dutch have demonstrated, an architecture and urbanism which expresses this, is a way of embracing the complexity and artificiality of our modern world.

As a result of a long modernist tradition and cultural tendency to be frugal, Dutch architects' quest for innovation and variety is coupled with pragmatic sensibilities.

Thus, this approach is often called 'Dutch pragmatism' or 'Dutch pragmatic modernism.' In the following section, specific tactics within this architectural approach will be analyzed for their potential application to North American suburbs. 
1 Maurizio Sabini, "Pragmatic Modernism: The Dutch Laboratory on Architecture, Landscape and the City," in Getting Real: Design Ethos Now: Abstracts. ed. Renee Cheng and Patrick J. Tripeny (Washington, DC: Association of Collegiate Schools of Architecture, 2006), 430

\section{CHAPTER 5.3 \\ AN APPLICATION OF DUTCH \\ PRAGMATISM TO NORTH AMERICAN POSTWAR SUBURBS}

Despite a contemporary desire for innovation and variety, the realities of the contemporary world, (ie. function, cost, profit, and constructability), serve to dictate built projects more than ever before. While postwar theorists discussed the merits of public buildings as mechanisms for citybuilding, now private projects are being seen as potential avenues to create public space and imageable places. Thus, this 'pragmatic' approach is extremely relevant to the transformation of suburban places. Historically, suburbs have been highly dictated by market demands. Because of their location, suburbs are less likely to attract public cultural attractions (at least until their density and transit can support it). In the meantime, there is a continuous need for residential and commercial uses. Contemporary market demands can be seen as an opportunity for place-making. The question is, how can designers respond, not through formulaic models, but through innovation? Some answers might be found within the tactics of Dutch pragmatism.
One fundamental idea within Dutch pragmatism is to create opportunities for landscape and public space through private ventures, such as housing developments or infrastructure projects. This practice suggests a kinship with both mat urbanism and landscape urbanism (discussed previously), which explored how built form could define landscape, and vice versa. Perhaps because of this legacy, Dutch designers are often simultaneously architects, landscape architects, and urban designers, or work closely within these disciplines. In "Pragmatic Modernism: The Dutch Laboratory on Architecture, Landscape and the City", Maurizio Sabini explains:

"A pragmatic, functional, performative mentality logically entertains the notion of disciplinary joint-ventures to provide the most effective, appropriate and articulated response to design problems. Public art, architecture, landscape design and urbanism are more often than not intertwined in many Dutch experimental interventions on the physical environment. "1

As a result of this practice, Dutch designers are adept at turning everything, "Even utilitarian works like bridges, tunnels, and viaducts", into an opportunity for creative 
design. $^{2}$

This tactic allows profitable programs to support a public realm, without having to strictly designate parcels for private program and public space. In the new urban cores of suburbia, the growing demand for increased private density (ie. residential and employment) could be used as an opportunity to provide much needed public spaces, and create a transition between a landscape dominated condition and a more urban one. (See Figure 1)

Another strong characteristic of Dutch pragmatism is a concept-driven design approach. Dutch designers consistently challenge convention; there is not one pre-conceived formula for each project or site. This process ensures a greater variety of urban experience. Some scholars suggest that the new approach of 'superdutch' architects is one of 'form follows concept', where "architects distil from the client's brief a high-powered idea, a 'concept', that lends direction to the design as a whole" 3 The concept-driven approach is also related to the frugality of Dutch tradition. Due to small budgets, clients cannot afford high quality materials. Hans Ibelings explains: "luxury is rarely one

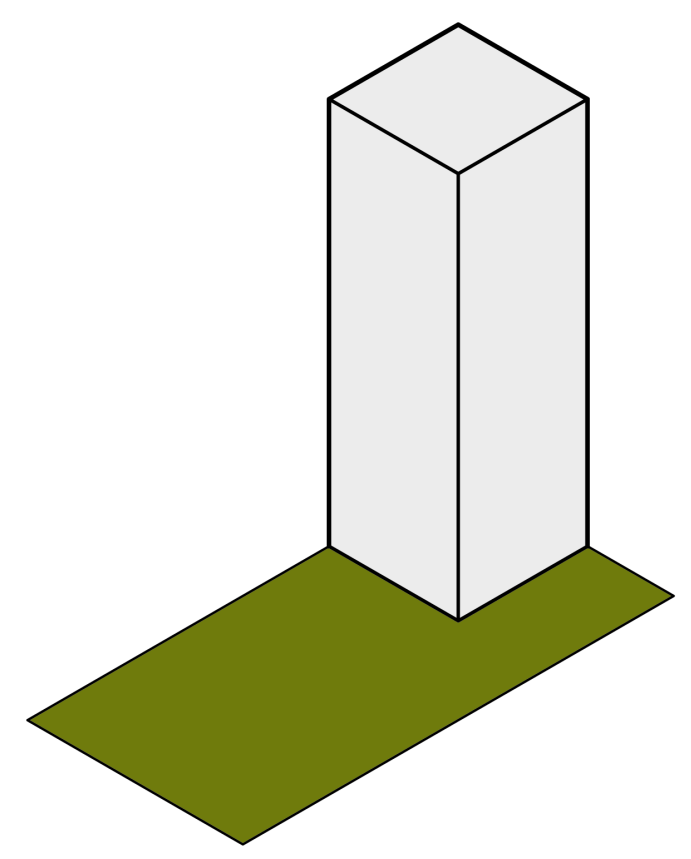

2 Hans lbelings, The Artificial Landscape:

Contemporary Architecture, Urbanism, and Landscape Architecture in the Netherlands (Rotterdam: NAi Publishers, 2000), 16

3 Bernard, Hulsman, Double Dutch: Architecture in the Netherlands since 1985 (Rotterdam: Nai010 Publishers, 2014), 8
ARCHITECTURE AND PUBLIC SPACE AS SEPERATE ENTITIES

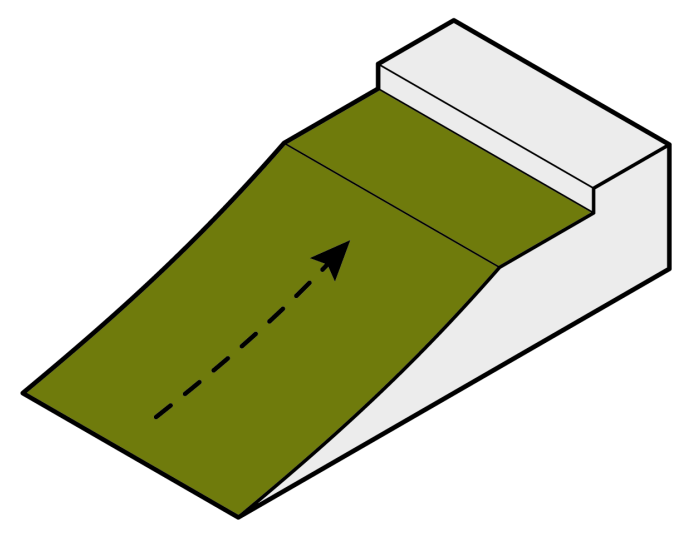

ARCHITECTURE AND PUBLIC SPACE INTEGRATED

Figure 1: Strategy 1 - Integration of landscape into architecture 


\section{CASE STUDY: \\ "DELFT INSTITUTE OF TECHNOLOGY LIBRARY" MECANOO}

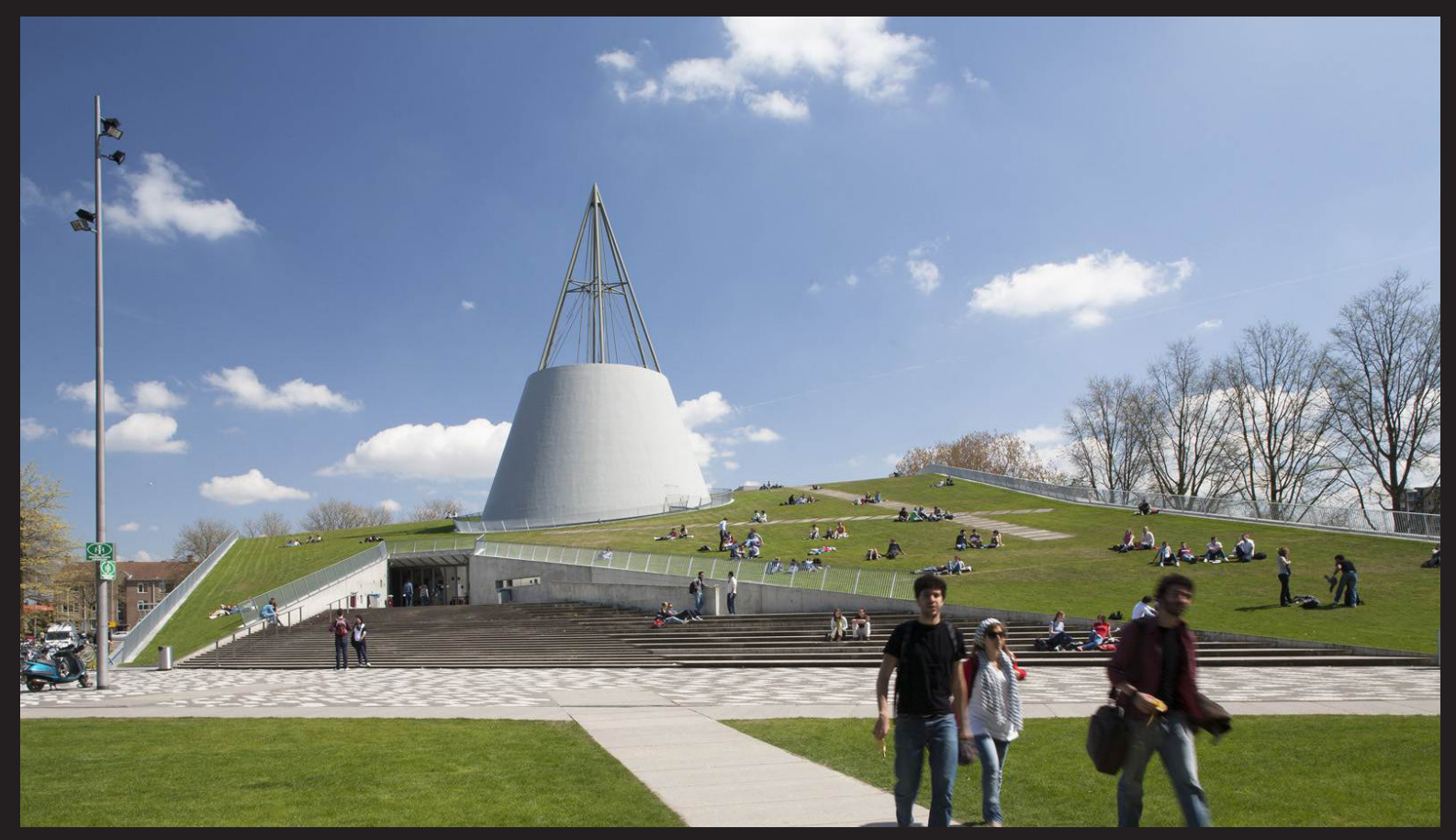

Figure 2: View towards the entrance to the TU Delft library

Mecanoo's Library at the Delft University of Technology (completed in 1997) is a clear example of architecture and landscape "conceived as a single entity." ${ }^{4}$ The interior space is contained under a gently sloping lawn; with curtain wall facades at two sides. The architecture has been largely absorbed into the landscape, except for a forty-meter high cone which pierces through the surface. The conical form allows sunlight to penetrate into the building, ${ }^{5}$ and serves as a highly visible landmark. This project presents a critical response to both landscape and mat urbanism. The form serves to extend the landscape and public space, but also distinguishes a clearly identifiable form. of costly materials or refined finishes, but translates instead into a spatial, visual, and tactile richness."6 Thus, Dutch designers are more likely to make dramatic formal moves than invest in fine grain details.

\section{In many ways, this tactic is a}

response to the lack of identifiability in modernist environments (as discussed in Chapter 2.2). It allows the form itself to create iconic imagery, without becoming too monotonous (as with orthodox modernism) or applying ornamentation (as in postmodernism). In this way, even private projects (housing, offices etc.) can become memorable landmarks.

In a purely pragmatic fashion, the concept is often driven by programmatic requirements. Thus the program has become the organizing unit of design, rather than a rigid modular unit (as in mat urbanism). Generally, this involves a manipulation or stacking of program to achieve an interesting organization. Maurizio Sabini suggests that while functionalist modernist facades had been simply, "a function of the inside program... contemporary Dutch architects have looked at program with a more pragmatic attitude, letting it be part of the design process and 


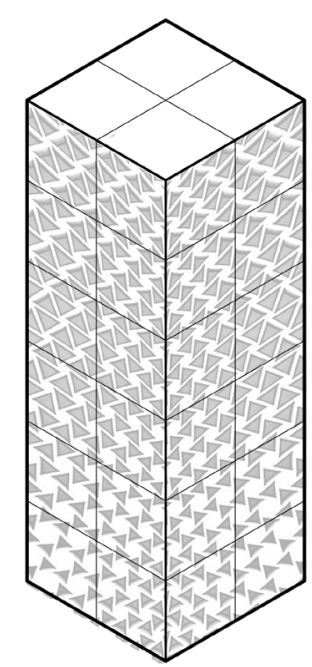

SIMPLE FORMAL ARRANGEMENT WITH COMPLEX FACADE

Figure 3: Strategy 2 - Concept-driven design approach

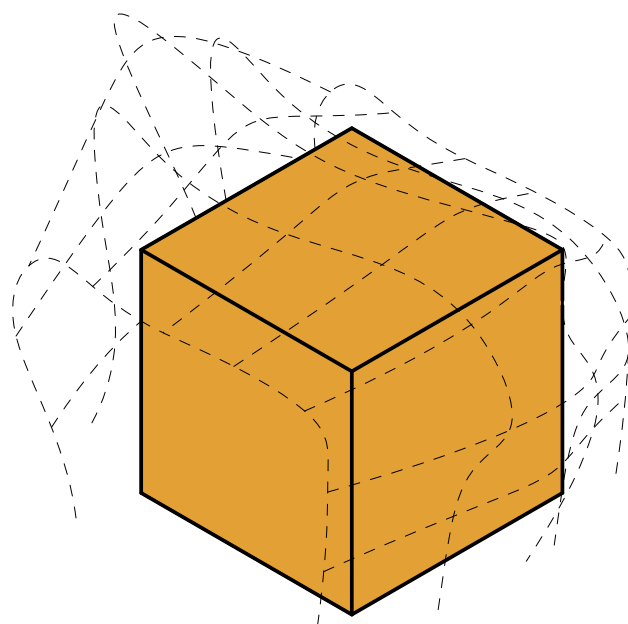

OBJECT BUILDING:

OUTSIDE FORM NOT RELATED

TO INTERNAL PROGRAM

Figure 4: Strategy 3 - Program-driven concept

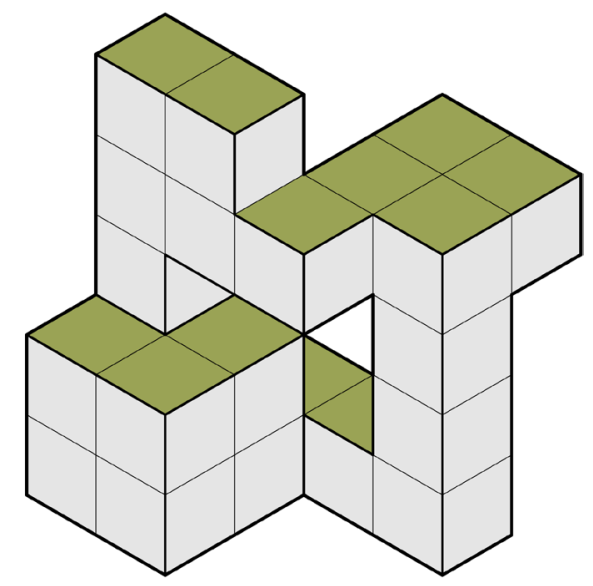

4 Hans Ibelings, The Artificial Landscape:

Contemporary Architecture, Urbanism, and Landscape Architecture in the Netherlands (Rotterdam: NAi Publishers, 2000), 46

$5 \mathrm{lbid}, 126$

$6 \mathrm{lbid}, 171$
DRAMATIC FORMAL ARRANGEMENT WITH SIMPLE FACADE

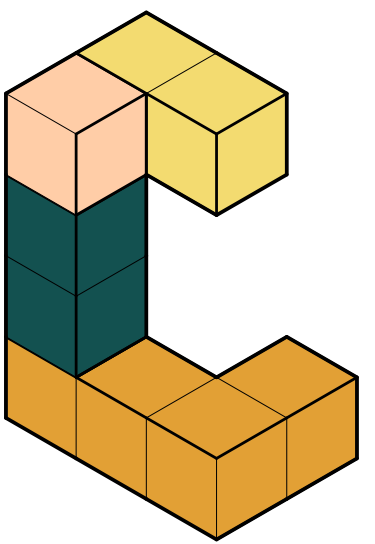

PRAGMATIC BUILDING

OUTSIDE FORM DRIVEN BY INTERNAL PROGRAM 


\section{CASE STUDY: \\ "MARKETHAL" - MVRDV}

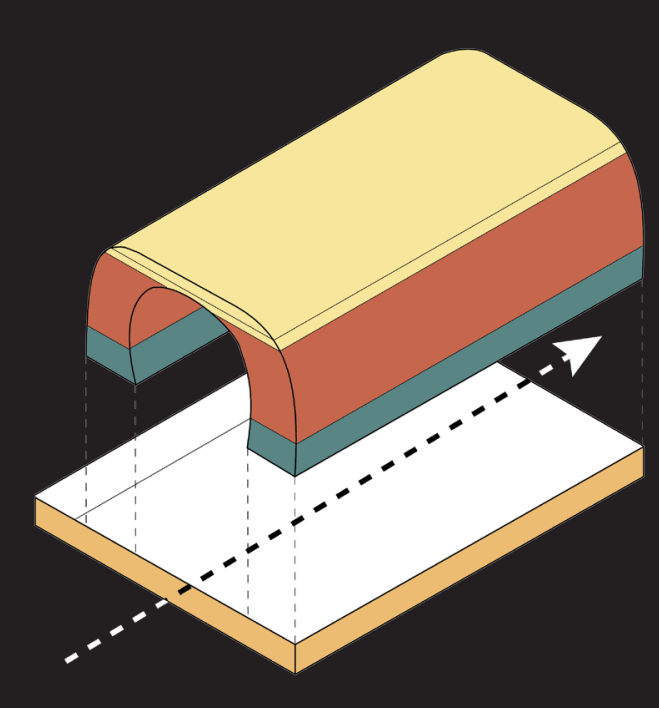

Figure 5: Programmatic

organization of Markethal (MVRDV)

MVRDV's Markethal (completed in 2015) has quickly become a prominent landmark in Rotterdam. The designers intended to create a large interior public space, similar to the great public halls or cathedrals of the past. However, in order to construct this public building in contemporary times, the project needed to secure profit, and satisfy market conditions. Thus, the designers manipulated a simple vault form to accommodate apartments and offices. This strategy also created a unique relationship between the private and public realms, with windows peering inward and downward towards the market. MVRDV's Winy Maas explains:

"The market hall has become a cathedral with housing inside it." of the actual form-making." 8 This allows the form to convey variety and innovation in its expression without counteracting its function; a strong contrast to so-called 'object buildings' from architects such as Frank Gehry and Daniel Libeskind, which only suit large public typologies. (Figure 3)

The Dutch architecture firm which best demonstrates this approach is MVRDV; named for founding partners Winy Maas, Jacob van Rijs, and Nathalie de Vries. MVRDV uses programmatic elements as building blocks for their design schemes. As Bernard Hulsman asserts; "they had replaced the old modernist battle-cry 'form follows function' with 'form follows statistics'."9 The firm often refers to these form-shaping statistics as 'datascapes.' Bart Lootsma explains:

"MVRDV visualizes the outcome of these factors in standardized diagrams or datascapes. Again, using computers, datascapes are then superimposed on one another-mapped - to reveal the project's constraints before the negotiation process is started up with those involved. This approach ultimately leads to a design in which different layers and fractures within the process remain visible. ${ }^{\prime 10}$

This process allows them to derive multiple 
iterations with the same programmatic requirements, and use restrictions as a means for creativity.

In a postwar suburban context, typologies like big box stores, largeplate offices, and factories, have been disregarded as having no potential to support architecture. However, seen through the lens of Dutch pragmatism, these programs could actually facilitate the creation of public space and landscape. (Figure 7).

This confidence at mixing multiple programs into single structures relates to the redemption of the megastructure concept within Dutch pragmatism. This approach is what architect Rem Koolhaas refers to as 'Bigness.' Koolhaas explores this notion through much of his built and written work. In Delirious New York (1978), Koolhaas interprets the skyscrapers of Manhattan as vertical megastructures, which serve multiple programmes within a single volume, but also participate as part a larger urban network. Koolhaas later explores this idea further through the article "Bigness" in $S, M, L, X L$ (1995). Within this piece he articulates that the greatest ability of the megastructure is its function to create

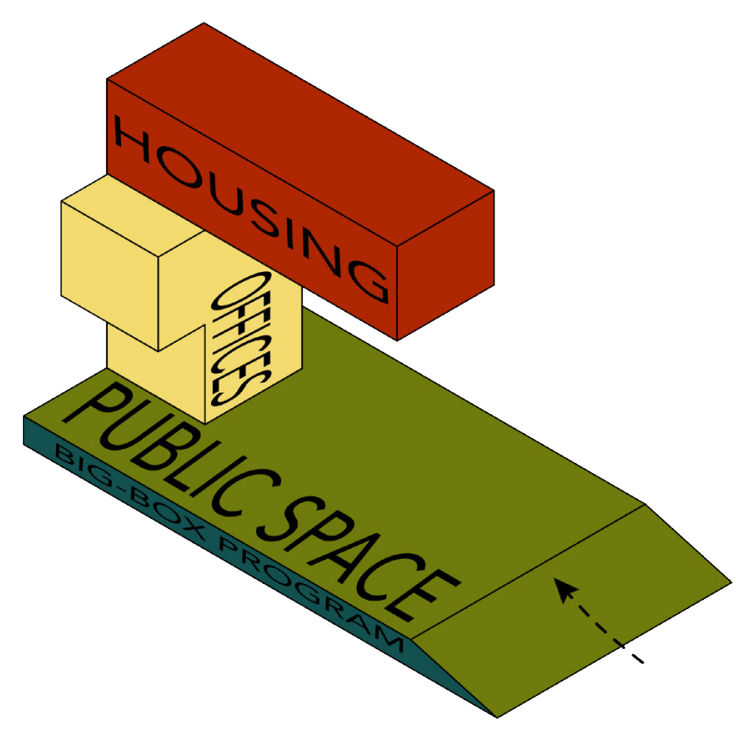

Figure 7: A pragmatic approach towards the programs of suburbia - providing a platform for landscape and public space, and recognisable form; through a megastructure of mixed programs

urbanism. Koolhaas states,

"Not only is Bigness incapable of establishing relationships with the classical city - at most, it coexists - but in the quantity and complexity of the facilities it offers, it is itself urban. Bigness no longer needs the city: it competes with the city; it represents the city; it preempts the city; or better still it is the city... Bigness = urbanism vs. Architecture." 11

In this way, he believes that only through a "theory of Bigness" can architecture "regain its instrumentality as vehicle of modernism." 12
7 Bernard, Hulsman, Double Dutch: Architecture in the Netherlands since 1985 (Rotterdam: Nai010 Publishers, 2014), 181

8 Maurizio Sabini,"Pragmatic Modernism: The Dutch Laboratory on Architecture , Landscape and the City, in Getting Real: Design Ethos Now: Abstracts. ed. Renee Cheng and Patrick J. Tripeny (Washington, DC: Association of Collegiate Schools of Architecture, 2006),427

9 Bernard, Hulsman, Double Dutch: Architecture in the Netherlands since 1985 (Rotterdam: Nai010 Publishers, 2014), 64

10 Bart Lootsma, Superdutch: New Architecture in the Netherlands (New York: Princeton Architectural Press, 2000), 24

11 Rem Koolhaas, "Bigness" in $S, M, L, X L$ (Rotterdam: 010 Publ., 1995), 514 - 515

12 lbid, 510 
13 Hans Ibelings, The Artificial Landscape:

Contemporary Architecture, Urbanism, and Landscape Architecture in the Netherlands (Rotterdam: NAi Publishers, 2000), 17

14 Bernard Hulsman, Double Dutch: Architecture in the Netherlands since 1985 (Rotterdam: Nai010 Publishers, 2014), 181

15 Maurizio Sabini, "Pragmatic Modernism: The Dutch Laboratory on Architecture, Landscape and the City," in Getting Real: Design Ethos Now: Abstracts. ed. Renee Cheng and Patrick J. Tripeny (Washington, DC: Association of Collegiate Schools of Architecture, 2006), 426

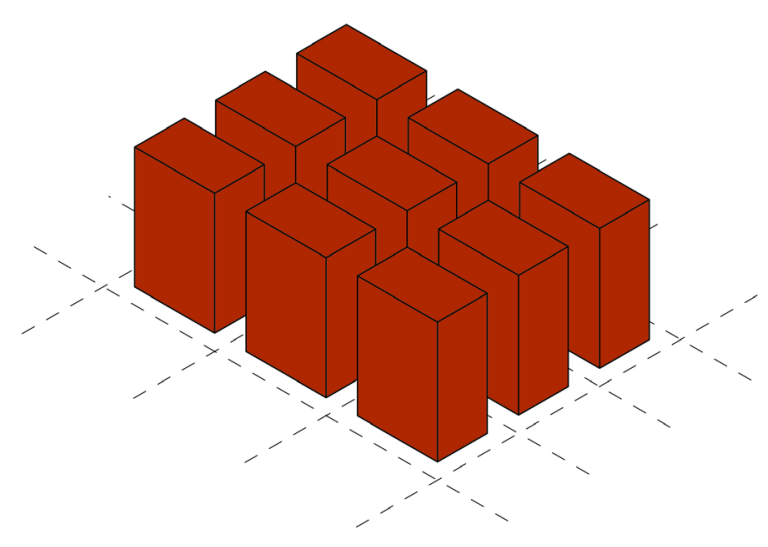

REPEATED PROTOTYPE BY SINGLE ARCHITECT

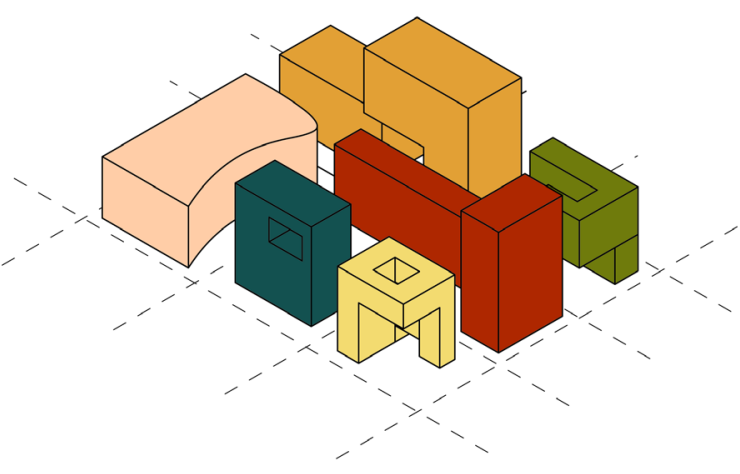

MULTIPLE SITES COMPLETED BY VARIOUS ARCHITECTS

Figure 8: Strategy 4 - Use of competition and cross-collaboration

The value of the megastructure is that it has the capacity to respond to the scale and complexity of contemporary programs and typologies. In reality, small scale, piecemeal construction is often not feasible in a contemporary construction climate, because the profits are not considered substantial enough to justify the investment. The challenge however, (as indicated from critiques of megastructures in the 1960s) is to balance this approach with a contemporary desire for variety, hierarchy, and human scale.

In the Netherlands, this challenge is met with a rigorous use of competition and cross collaboration. Large development schemes are rarely executed by a single architect; they are usually broken up into multiple sites or buildings. In this way, "Even variation is designed and institutionalized." "13 This practice provides an opportunity for multiple architectural visions, rather than a repeated prototypical model. Maurizio Sabini explains:

"In such a climate, radical and provocative proposals are not discouraged, rather they are welcomed, as they have to be filtered anyway through the process of a larger dialog." 14

The culture of competition forces designers to think 'outside the box' and entertain more possibilities. ${ }^{15}$ This, along with programs for subsidies and awards, provides a platform for young architects 
to receive commissions and establish

practices.

In order to provide vibrant and identifiable urban places in suburbia, the provision of variety should be given high priority. To better facilitate this, it would be beneficial to divide large redevelopment sites into multiple parcels, after which different architectural projects can be manifested.

Dutch pragmatism has emerged from a long discourse on the evolution of modernism. Its strategies are representative of a desire for greater variety and innovation, as well as practicality. These ideas could be adapted to the new urban cores of the North

American suburbs, as is demonstrated in this thesis project. 


\section{PART 6:}

AN URBAN STRATEGY FOR SUBURBIA ROCKWOOD MALL REDEVELOPMENT PROPOSAL

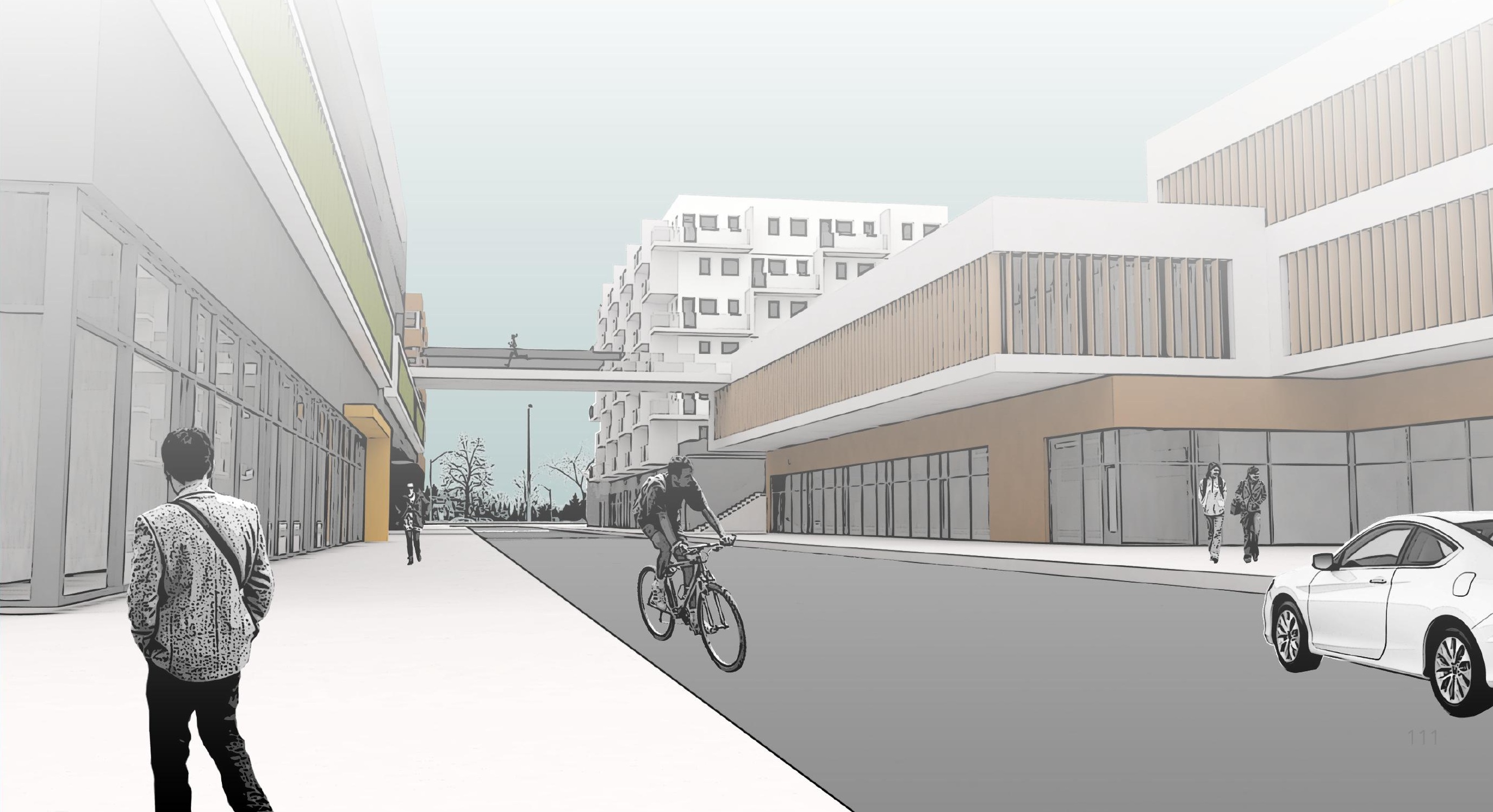




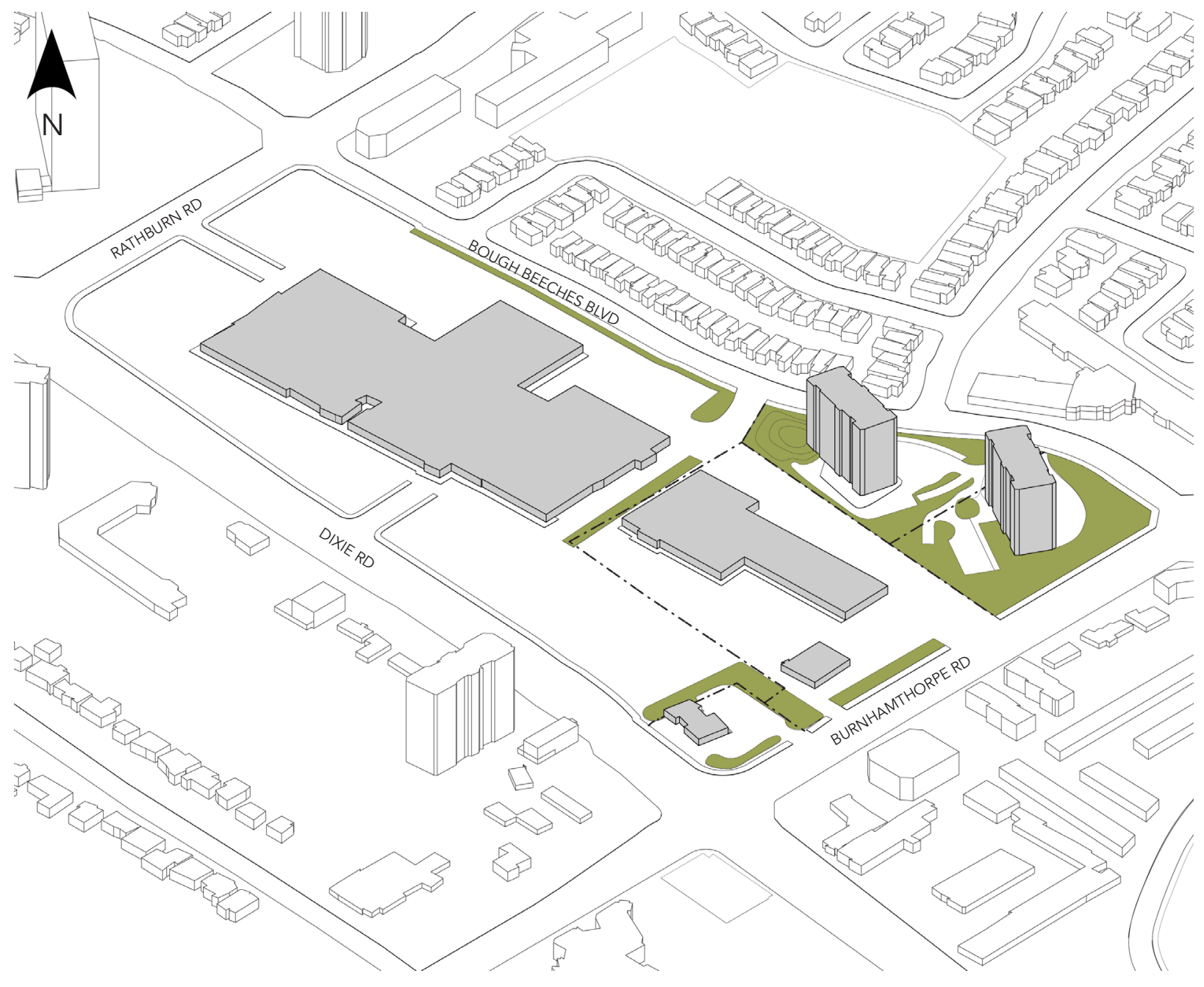

\section{INTRODUCTION}

As highlighted in Part 4, the existing condition of the Rockwood Mall is not meeting its potential as an urban core for the neighbourhood of Rathwood/ Applewood in Mississauga. The proposed urban design scheme interprets and implements the objectives of this thesis, which have emerged from the research.

The following site strategies establish the urban parameters for a potential development of the site. 


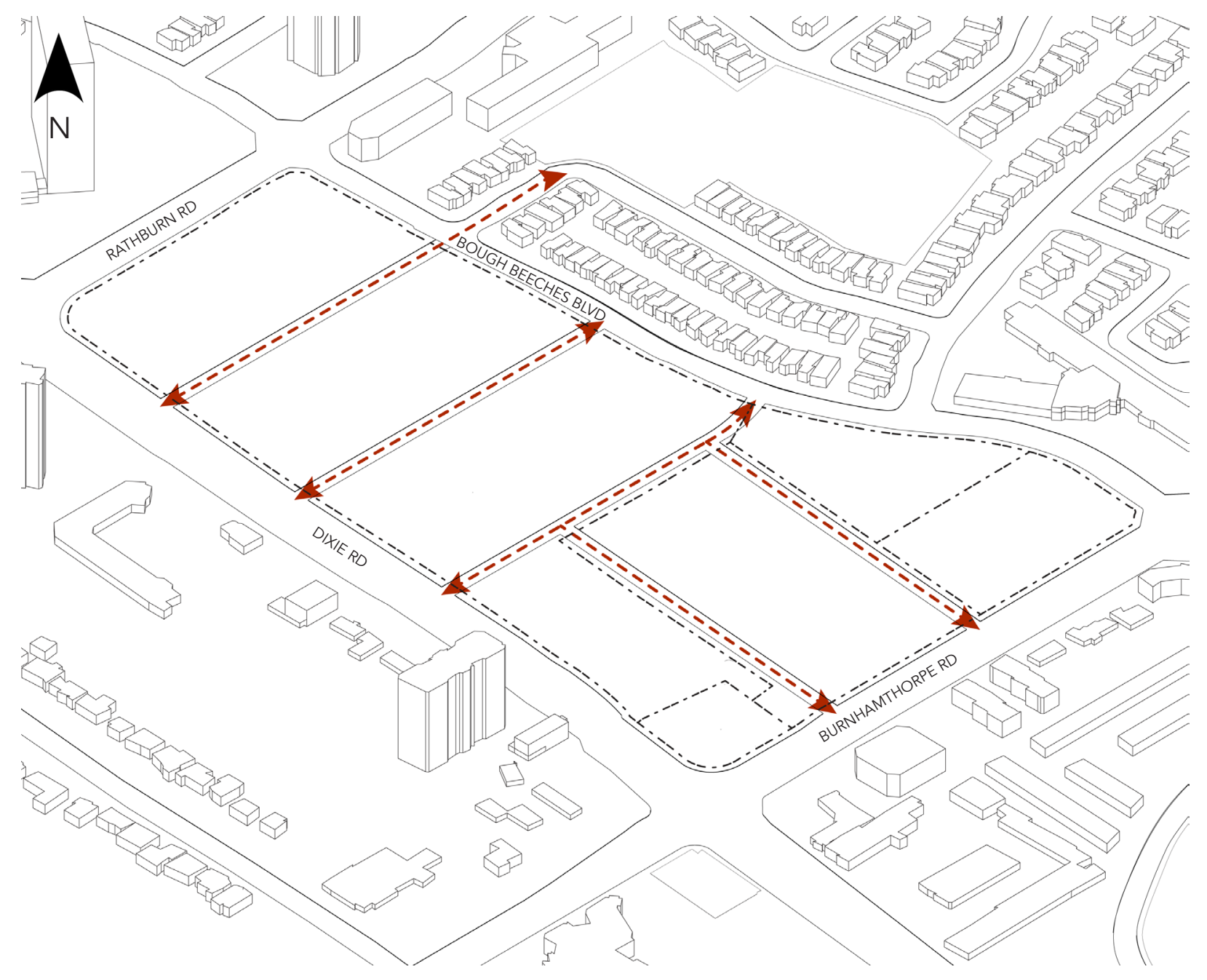

\section{SITE STRATEGY 1:}

Divide the site into multiple parcels based on existing property lines, and adjacent streets. These boundaries will form the property lines for architectural megastructures. The location of these boundaries along existing property lines allows for staged demolition of existing buildings as development proceeds. 


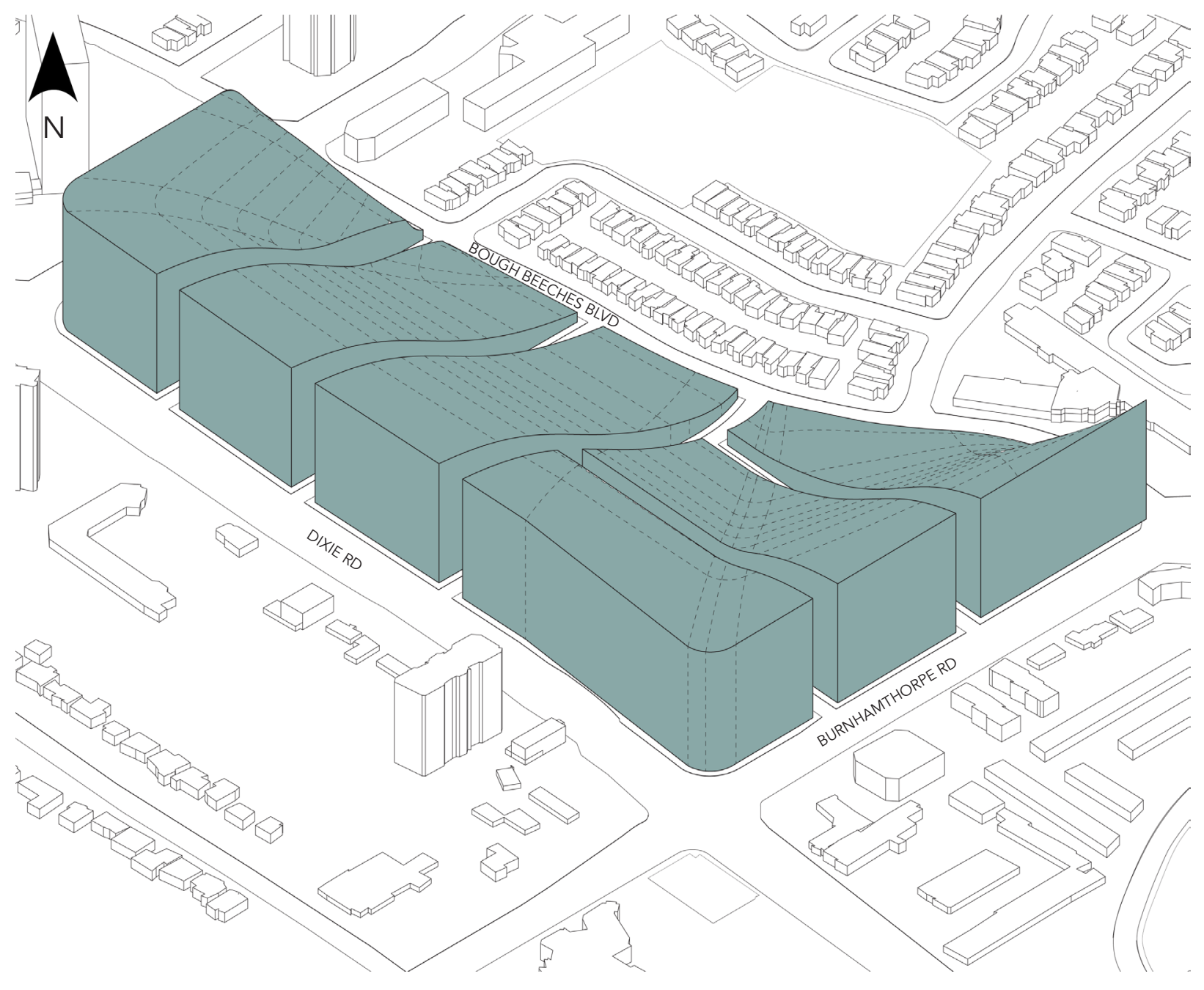

SITE STRATEGY 2:

Create a height gradient which responds to arterial streets. Maintain low rise towards existing single-family homes. 


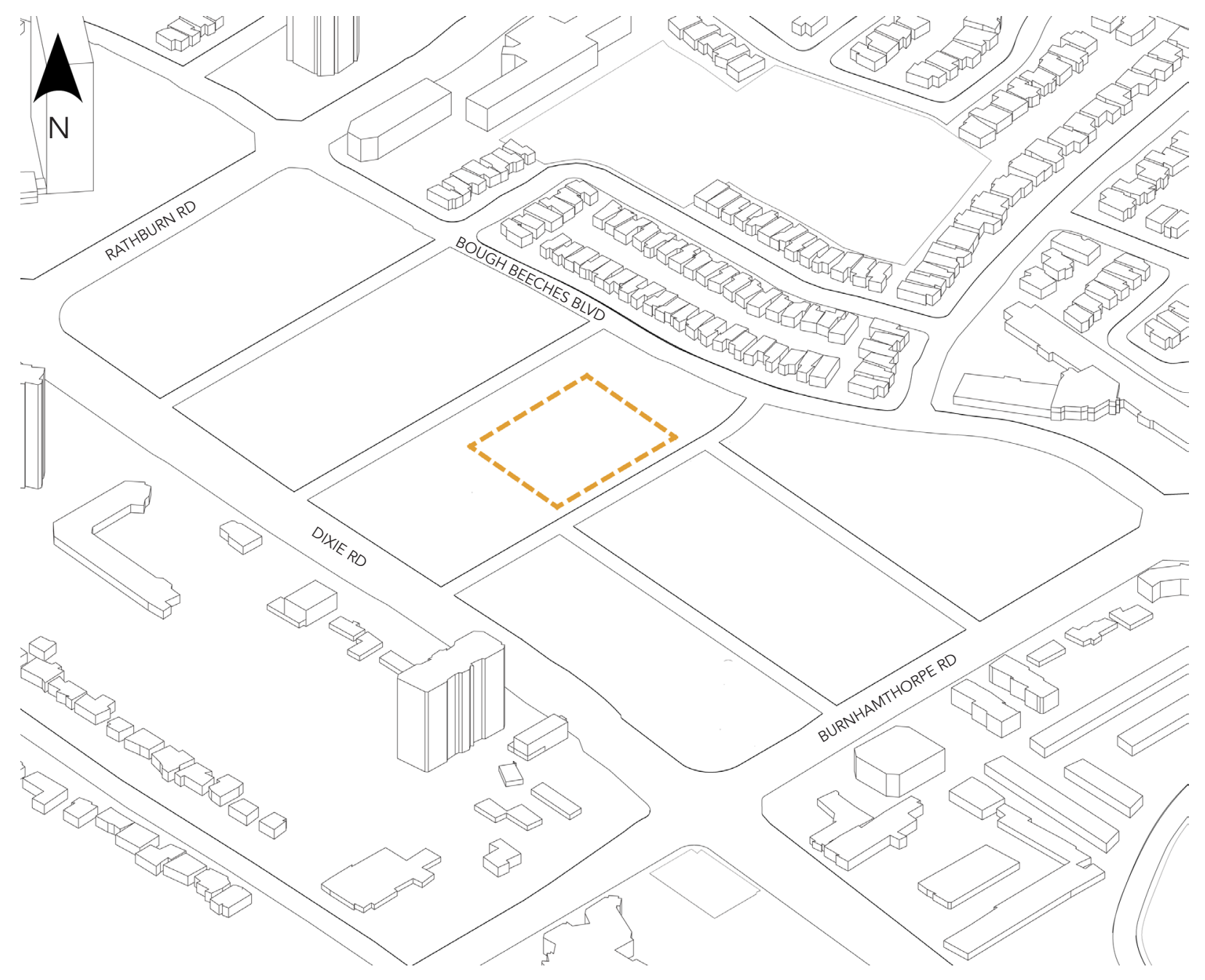

\section{SITE STRATEGY 3:}

Create a significant public open space in the centre of the development. This is to provide a central and recognisable orientation point which asserts greater hierarchy over the other open spaces. 


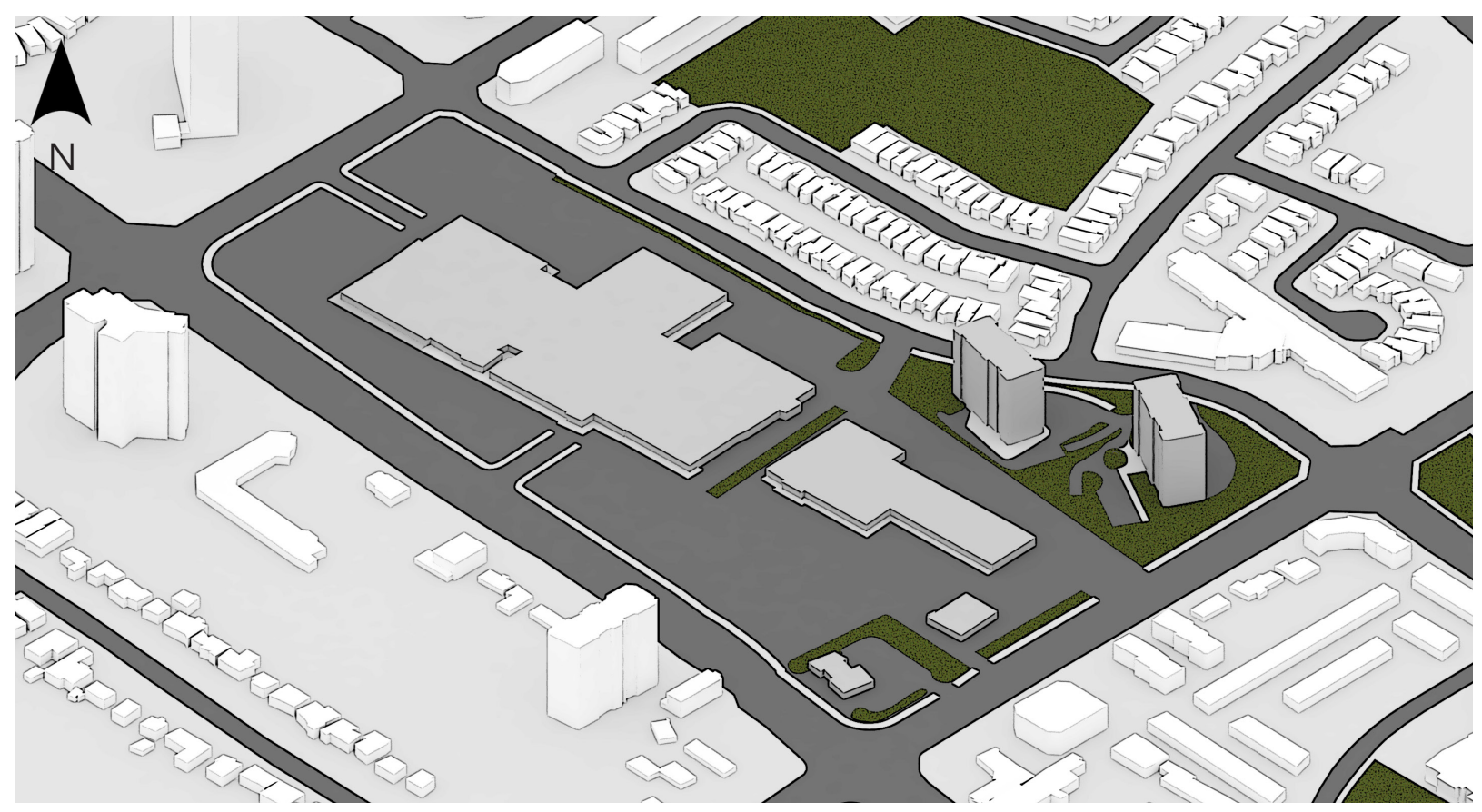

EXISTING CONDITION

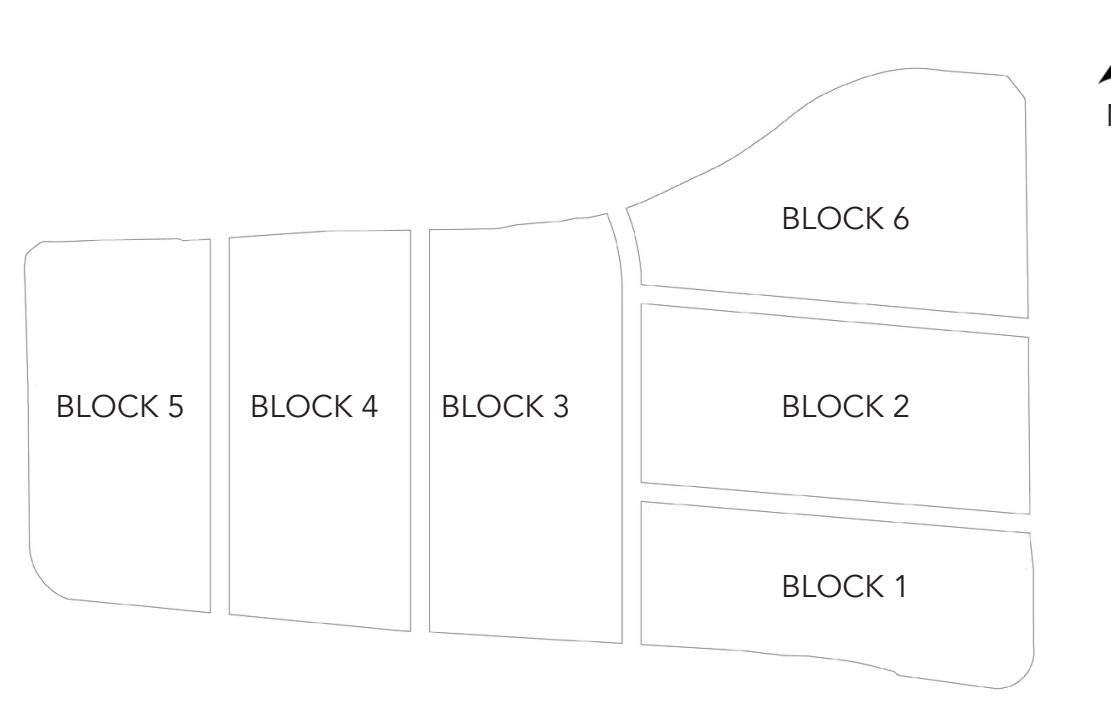

\section{PHASING OF DEVELOPMENT}

As discussed in Chapter 2.3, a lack of incrementalism has commonly been a major criticism of orthodox modern, megastructure and mat urbanism schemes. Large urban projects were generally designed as complete, rigid master plans, and did not allow for much change throughout the design and construction process. As such, a lack of incrementalism has been tied to a lack of variety.

Today, large development projects are completed in phases. This allows for a more gradual increase in density, and the sale of office and residential units to fund future phases. Through an emphasis on design quality and the involvement of several design teams, this process can result in a greater variety of architecture.

For the proposed design, a series of megastructures have been designed to support additional volumes as density increases. The sequence of demolition allows for existing buildings to operate for as long as possible. 


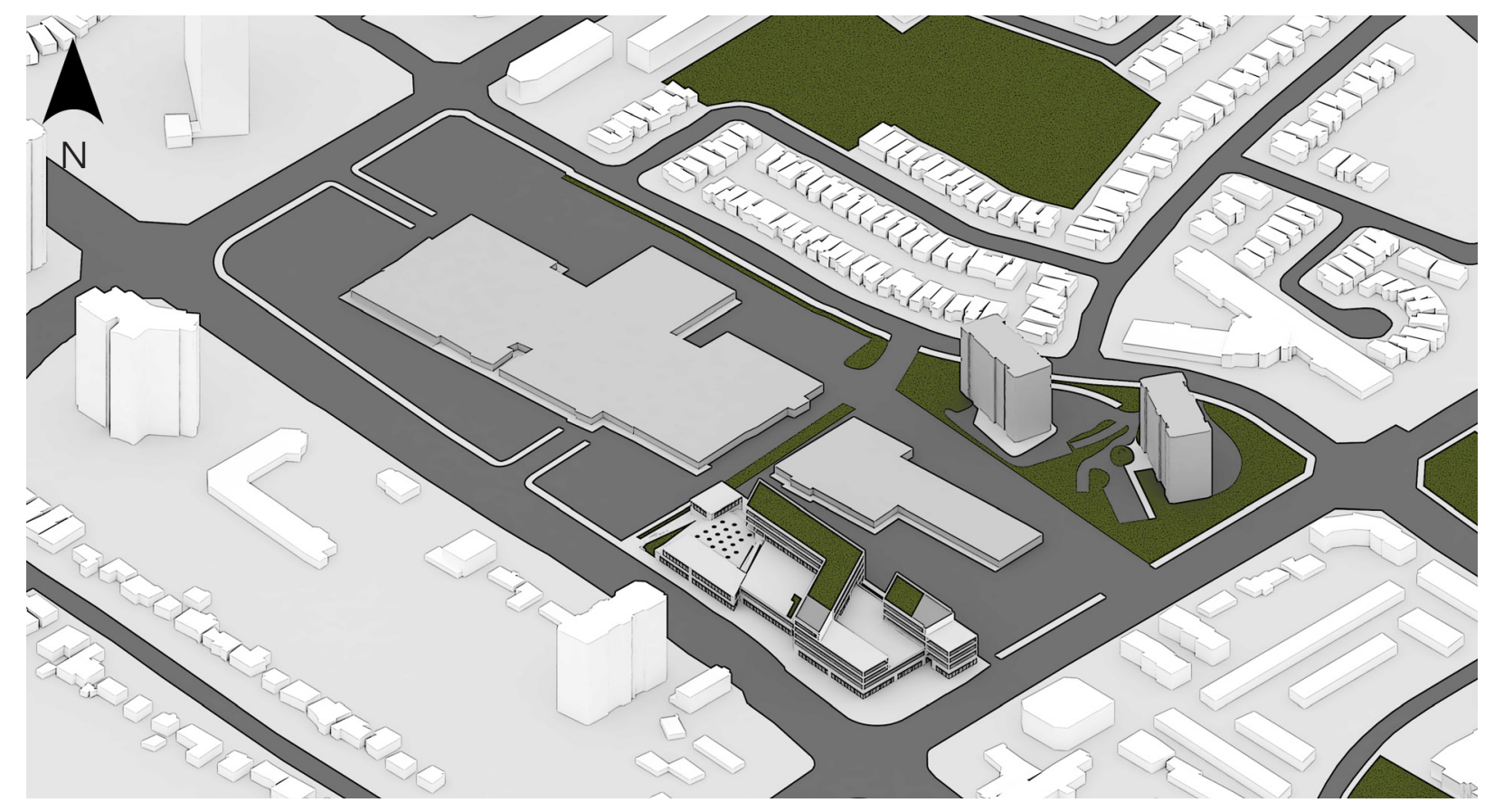

RETAIL/

IGHT INDUSTRIAL

RESIDENTIAL

PUBLIC/

INSTITUTIONAL

OFFICE

PARKING

GREENHOUSE

\section{PHASE 1}

The gas station at the intersection of Dixie and Burnhamthorpe Roads is demolished to begin construction of Block 1. This is the most major intersection of the Rathwood/ Applewood neighbourhood, and thus, the natural starting point for development. Block 1 begins to establish a streetwall edge condition at this corner.

The initial phase would accommodate a mix of retail, institutional, and office spaces. Accessible public plazas are created on the lower roof surfaces, which are bordered by shops and restaurants.

\section{INCREASED GROSS FLOOR AREA}

RETAIL/LIGHT INDUSTRIAL: 12700 sq. m LOW-RISE RESIDENTIAL:0 sq. $m$ APARTMENTS/CONDOS: 0 sq. $\mathrm{m}$ PUBLIC/INSTITUTIONAL: 7350 sq. m OFFICE: 9635 sq. $\mathrm{m}$ 


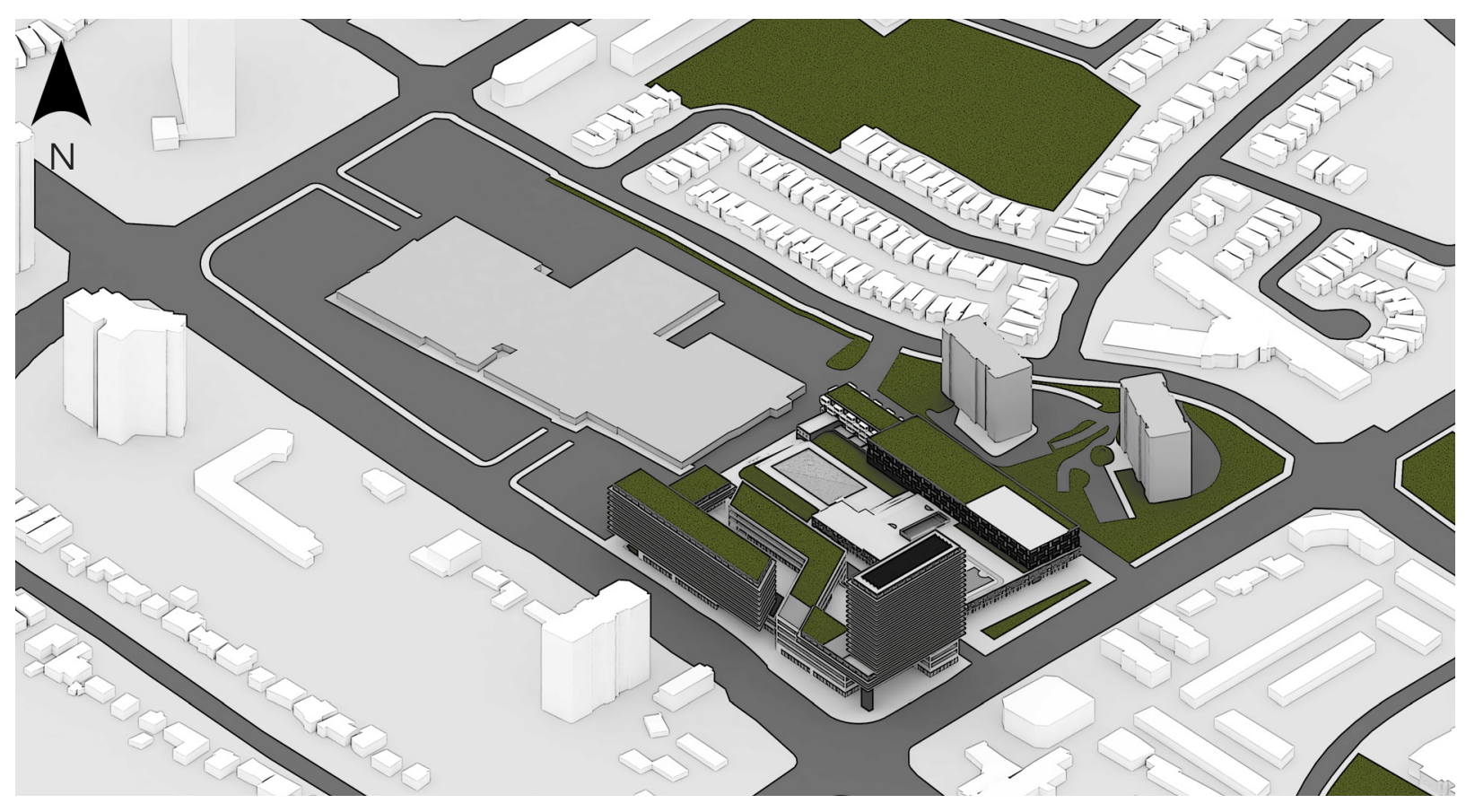

\section{PHASE 2}

The strip plaza section of the mall is demolished to begin construction of Block 2 , containing retail, offices and mid-rise residential units.

Public spaces containing an ice rink and sports courts would be created on the lower roof surfaces.

Residential units are added to Block 1, which establish a stronger presence at the corner of Dixie and Burnhamthope.

\section{INCREASED GROSS FLOOR AREA}

RETAIL/LIGHT INDUSTRIAL: 12745 sq. m LOW-RISE RESIDENTIAL: 0 sq. $\mathrm{m}$ APARTMENTS/CONDOS: 47259 sq. $m^{\star \star}$ PUBLIC/INSTITUTIONAL: 9309 sq. $\mathrm{m}$ OFFICE: 12667 sq. $\mathrm{m}$

** EQUIVALENT TO APPROX. 850 ONEBEDROOM UNITS 


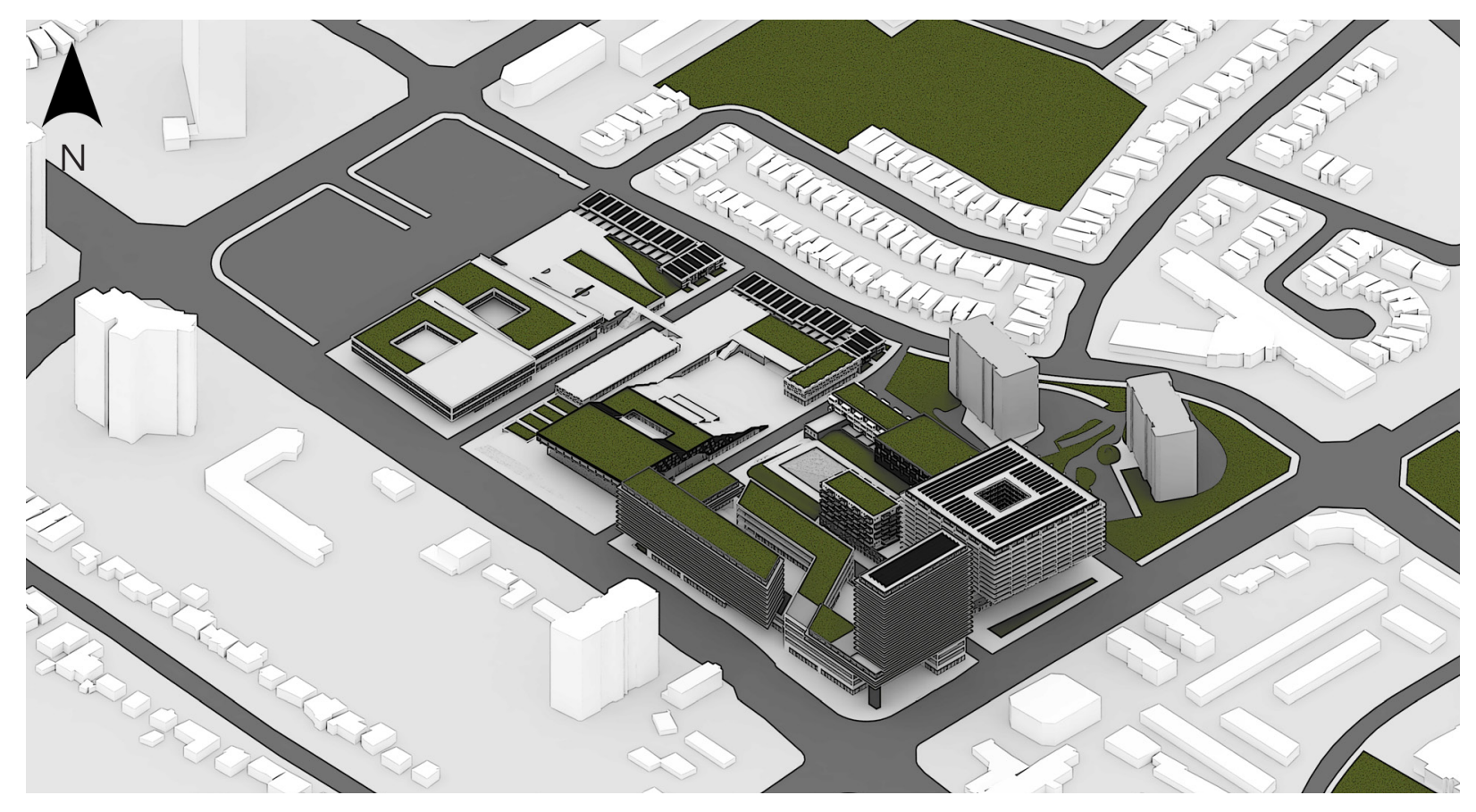

\section{PHASE 3}

The main volume of Rockwood Mall is demolished to begin construction of the third and fourth blocks.

Block 3 includes a large public market and a large open space with amphitheater seating. Block 4 contains an elementary school to accommodate the growing population. Outdoor recreational spaces are created along the lower roof surfaces, and are directly accessible to the school.

Rows of townhouses are incorporated into the blocks, facing the existing residential street to the north. Additional residential units are added to Block 2.

\section{INCREASED GROSS FLOOR AREA}

RETAIL/LIGHT INDUSTRIAL: 20844 sq. m LOW-RISE RESIDENTIAL: $5208 \mathrm{sq} \cdot \mathrm{m}^{*}$ APARTMENTS/CONDOS: 51822 sq. $\mathrm{m}^{* *}$ PUBLIC/INSTITUTIONAL: 16422 sq. $\mathrm{m}$ OFFICE: 7350 sq. m

* 31 THREE-BEDROOM TOWNHOUSES

** EQUIVALENT TO APPROX. 940 ONEBEDROOM UNITS 

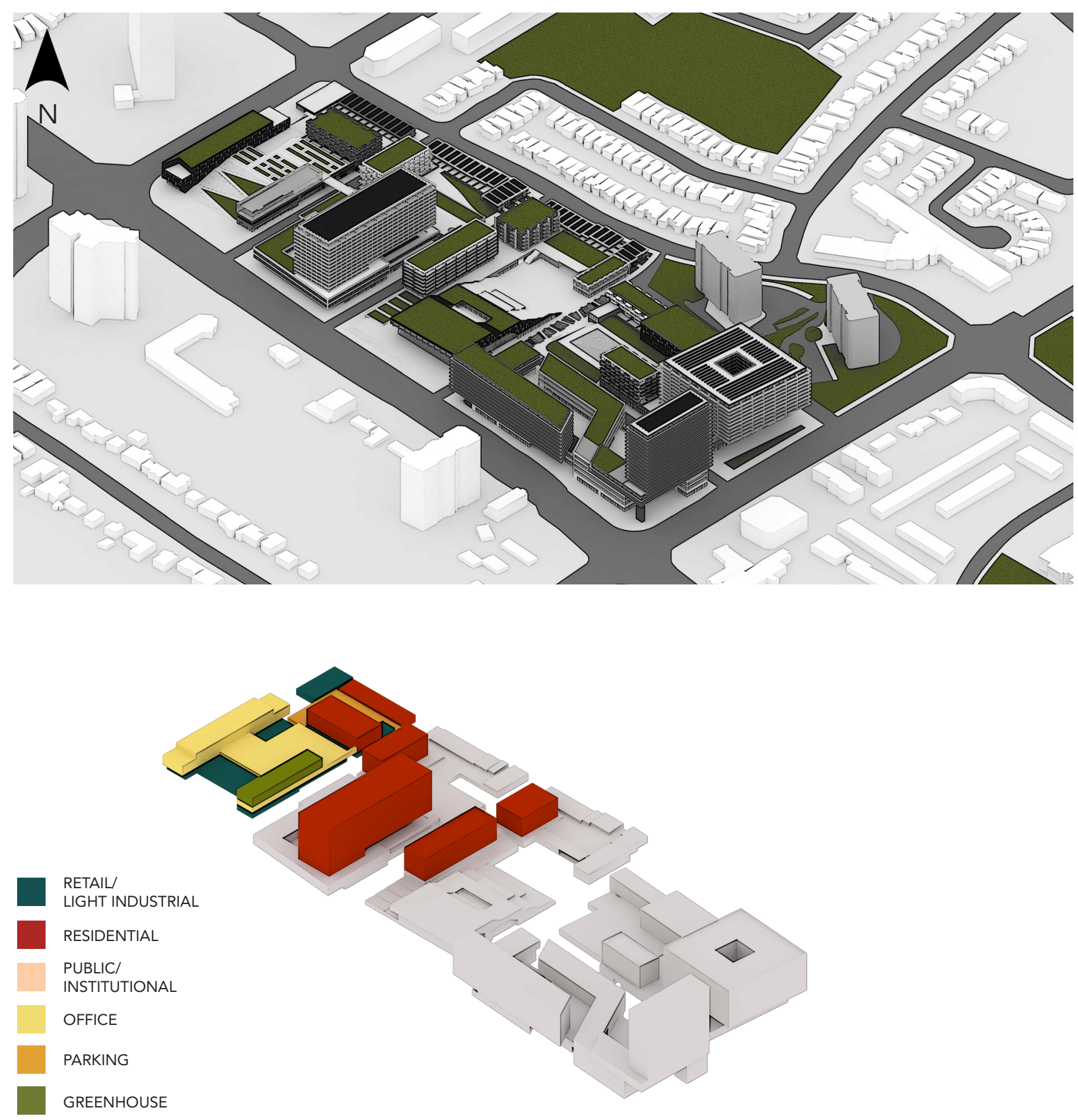

\section{PHASE 4}

Block 5 begins construction, including retail, offices, townhouses and mid-rise residential. The large lower roof surface is utilized for urban farming, with a supporting greenhouse.

Additional residential units are added to Blocks 3 and 4 . A pedestrian street is created between Blocks 2 and 3 .

\section{INCREASED GROSS FLOOR AREA}

RETAIL/LIGHT INDUSTRIAL: 9116 sq. m LOW-RISE RESIDENTIAL: 1680 sq. $\mathrm{m}^{*}$ APARTMENTS/CONDOS: 63668 sq. $m^{\star \star}$ PUBLIC/INSTITUTIONAL: 0 sq. $\mathrm{m}$ OFFICE: 9353 sq. $\mathrm{m}$

* 10 THREE-BEDROOM TOWNHOUSES ** EQUIVALENT TO APPROX. 1150 ONEBEDROOM UNITS 

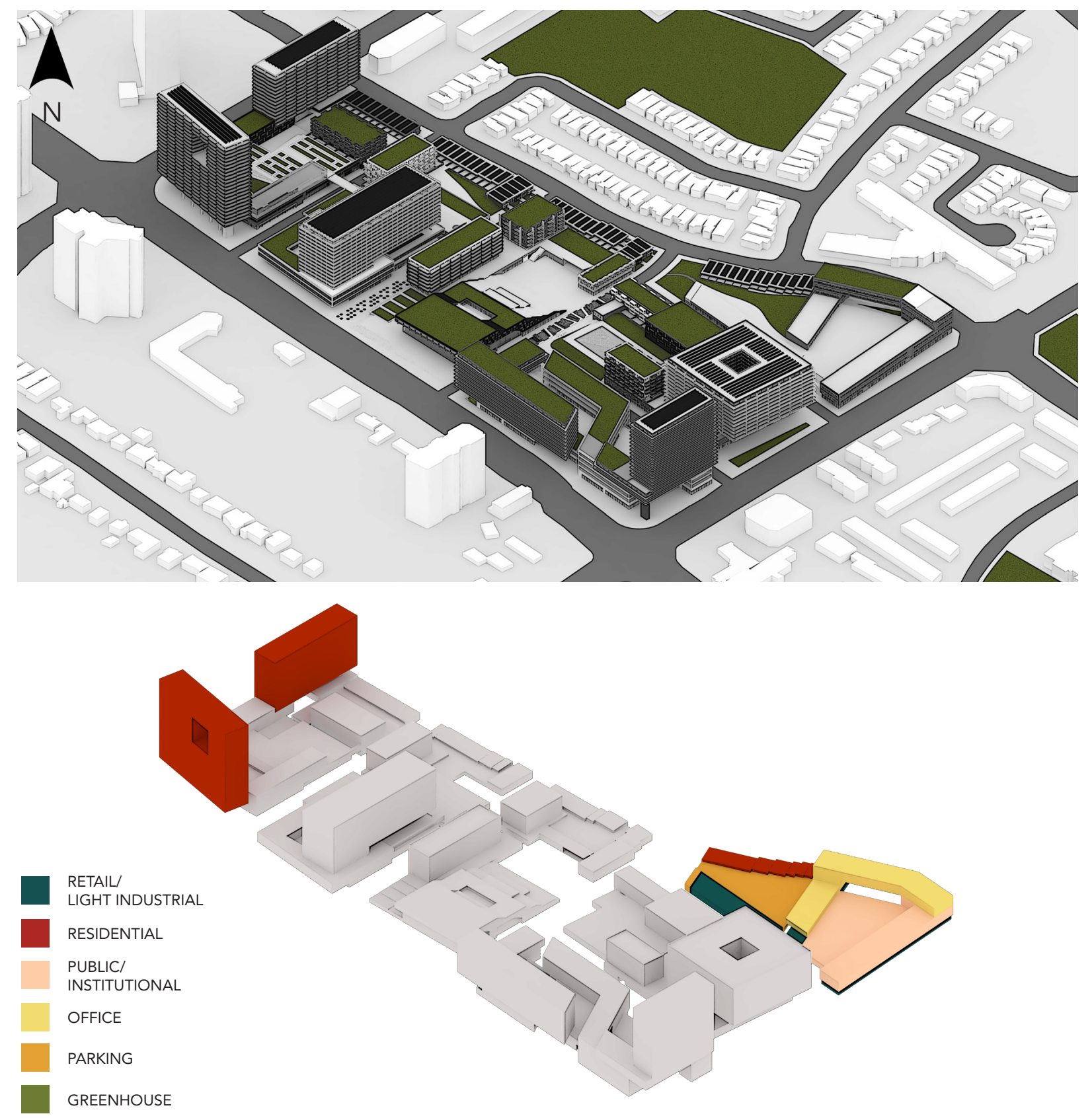

\section{PHASE 5}

The retirement housing towers are demolished to begin construction of Block 6. Although these existing towers support a high density, the existing configuration was highly isolated from the street, and not flexible to accommodate additional volumes at grade. Block 6 accommodates retail, offices and mid rise residential, as well a high school to support the growing population. The central open space becomes a social space for students and residents, with potential space for a skate park.

Additional residential units are added to Block 5. A pedestrian-only street is created in between Blocks 3 and 4 .

\section{INCREASED GROSS FLOOR AREA}

RETAIL/LIGHT INDUSTRIAL: 5582 sq. m LOW-RISE RESIDENTIAL: 2184 sq. $\mathrm{m}^{*}$ APARTMENTS/CONDOS: 54280 sq. $m^{\star *}$ PUBLIC/INSTITUTIONAL: 9288 sq. $\mathrm{m}$ OFFICE: 6037 sq. $\mathrm{m}$

* 13 THREE-BEDROOM TOWNHOUSES AND

** EQUIVALENT TO APPROX. 985 ONEBEDROOM UNITS 

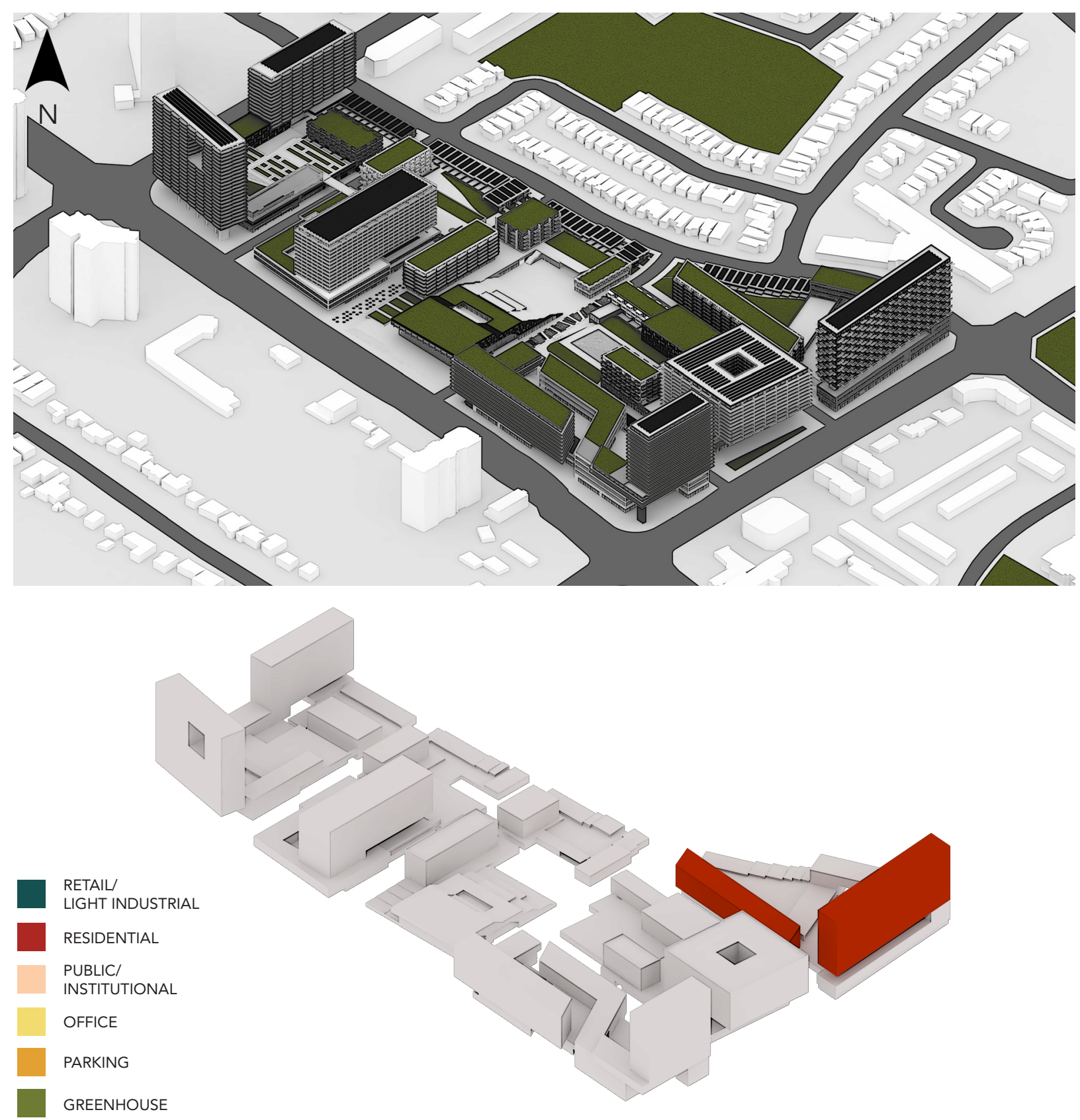

PHASE 6

Additional residential units are added to Block 6.

\section{INCREASED GROSS FLOOR AREA}

RETAIL/LIGHT INDUSTRIAL: 0 sq. m LOW-RISE RESIDENTIAL: 0 sq. $m$ APARTMENTS/CONDOS: 49825 sq. $m^{\text {** }}$ PUBLIC/INSTITUTIONAL: 0 sq. $\mathrm{m}$ OFFICE: 0 sq. $\mathrm{m}$

** EQUIVALENT TO APPROX. 900 ONEBEDROOM UNITS 

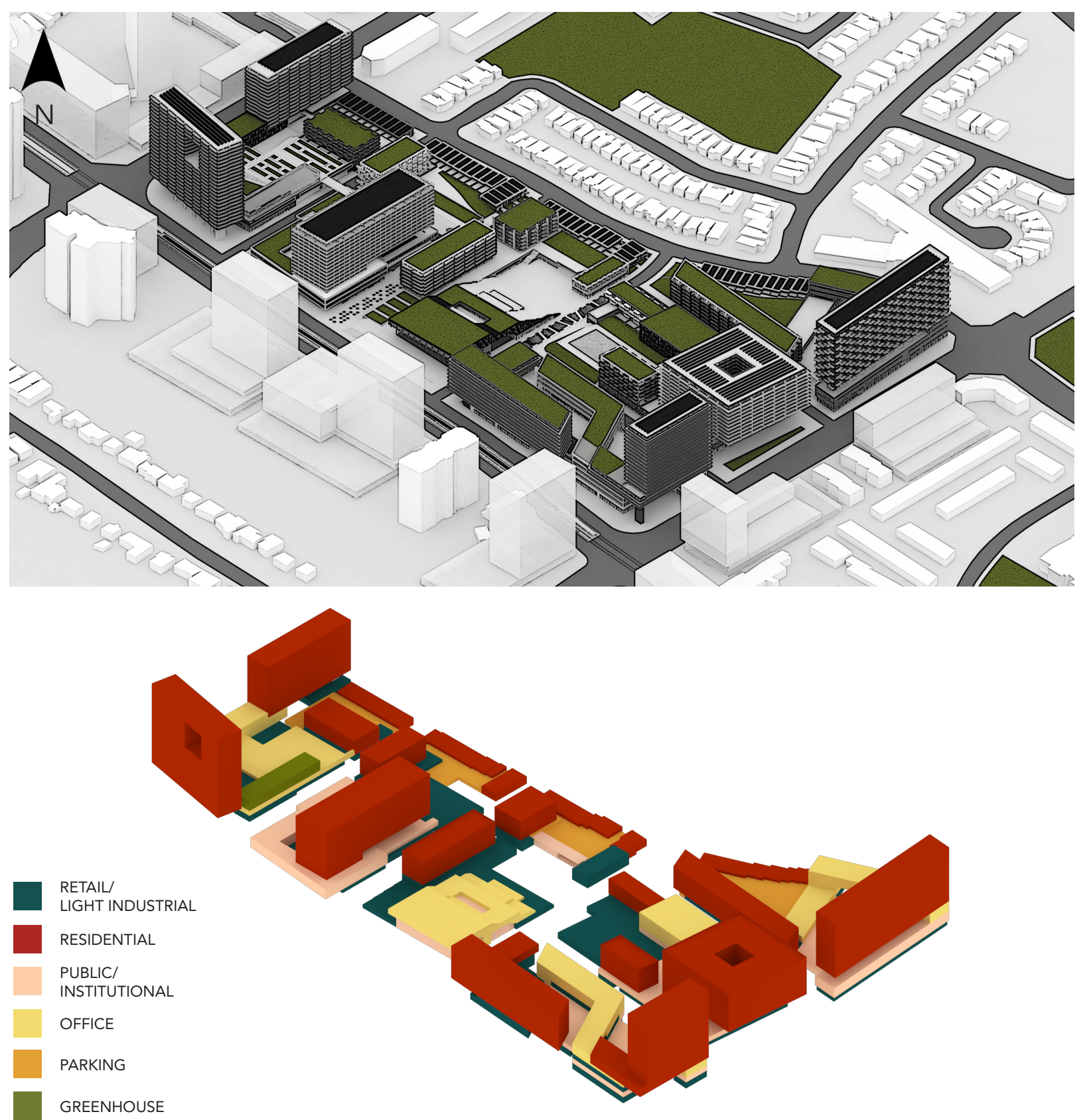

PHASE 7: PROJECTED DEVELOPMENT

The Rockwood Mall redevelopment scheme would encourage additional development along the surrounding arterial streets; either simultaneous and/or proceeding the proposed development. The proposed density could be better facilitated (or anticipated) through the addition of higher order transit (such as Light-Rail) along Dixie Rd.

\section{TOTAL REDEVELOPMENT DENSITY}

RETAIL/LIGHT INDUSTRIAL: 60987 sq. m LOW-RISE RESIDENTIAL: 18144 sq. $\mathrm{m}^{*}$ APARTMENTS/CONDOS: 266854 sq. $\mathrm{m}^{* *}$ PUBLIC/INSTITUTIONAL: 42369 sq. $\mathrm{m}$ OFFICE: 45042 sq. m

* 54 THREE-BEDROOM TOWNHOUSES ** EQUIVALENT TO APPROX. 4825 ONEBEDROOM UNITS 
A

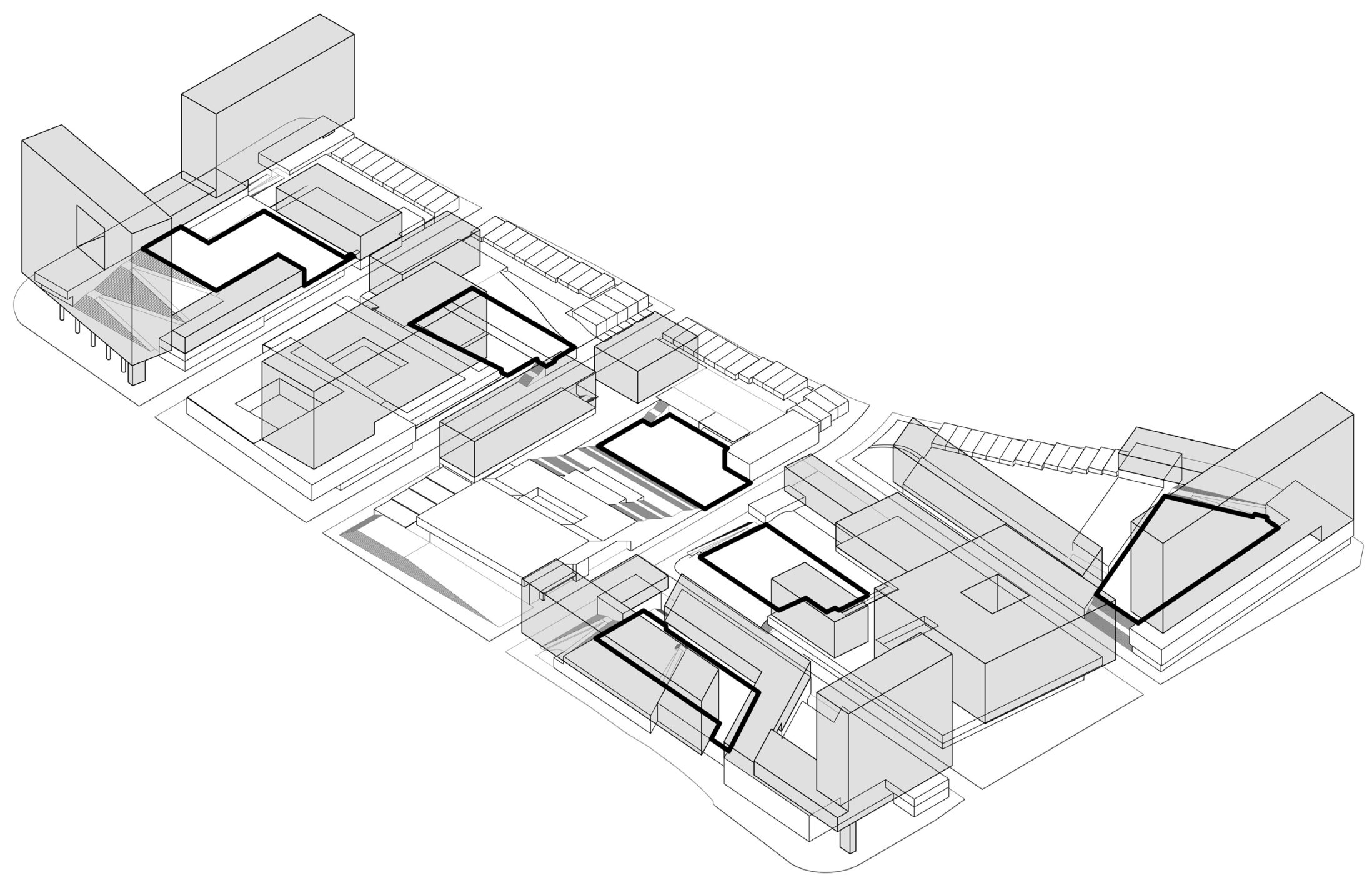




\section{PRIMARY URBAN SPACES}

Each block is designed to support programmed public space along its lower roof surfaces. The intention is for the public realm to be extended from the pavement into a continuous network.

Generally, there is one predominant public space per block. The central open space with amphitheatre asserts greater hierarchy than the other spaces, as emphasized by its at-grade condition. 
LIGHT INDUSTRIAL

RESIDENTIAL

PUBLIC/

INSTITUTIONAL

OFFICE

PARKING

GREENHOUSE

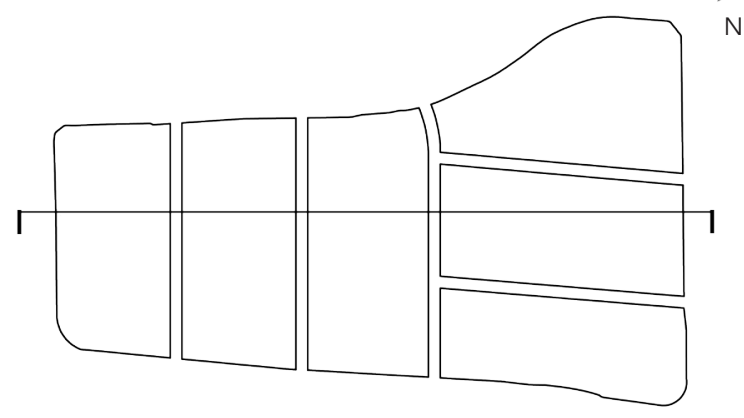

SITE SECTION A

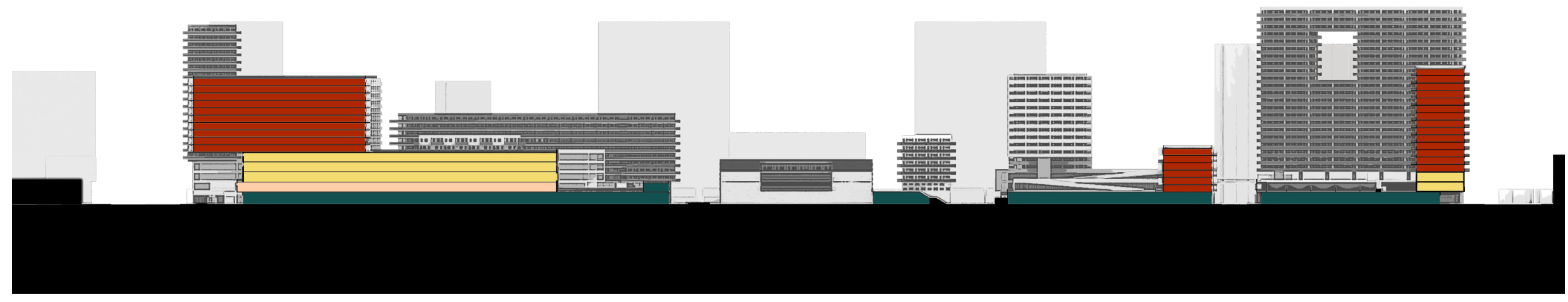




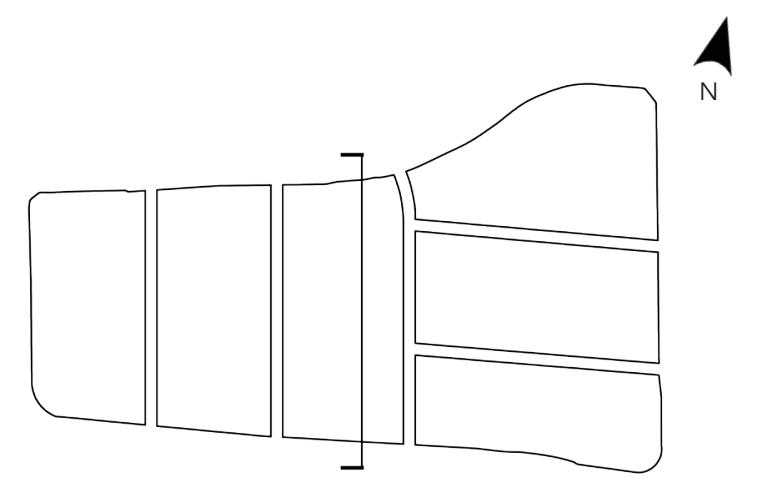

SITE SECTION B

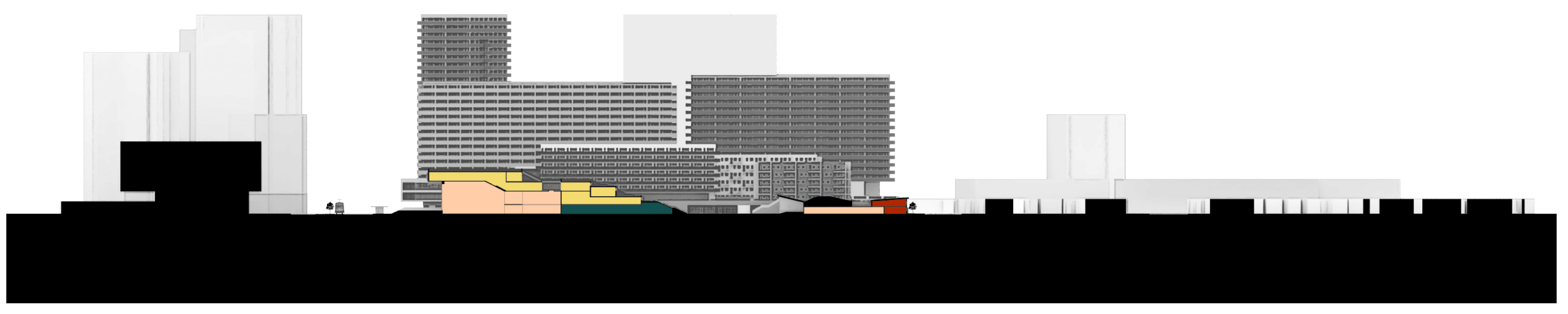




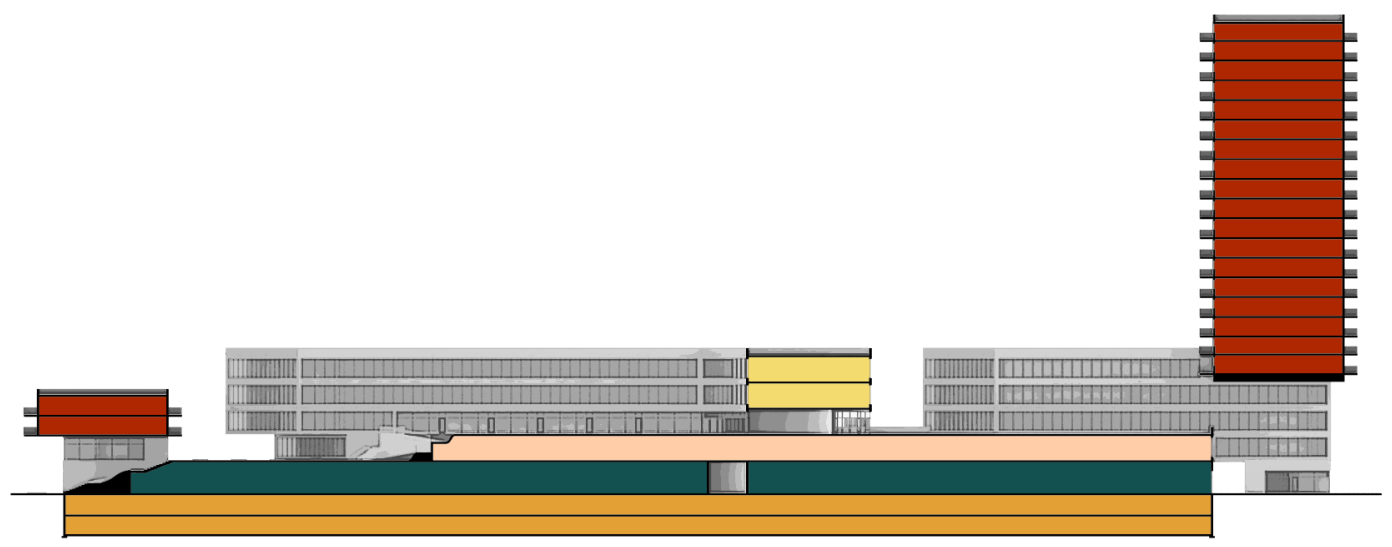

RETAIL/
LIGHT INDUSTRIAL
RESIDENTIAL
PUBLIC/
INSTITUTIONAL
OFFICE
PARKING
GREENHOUSE

SECTION

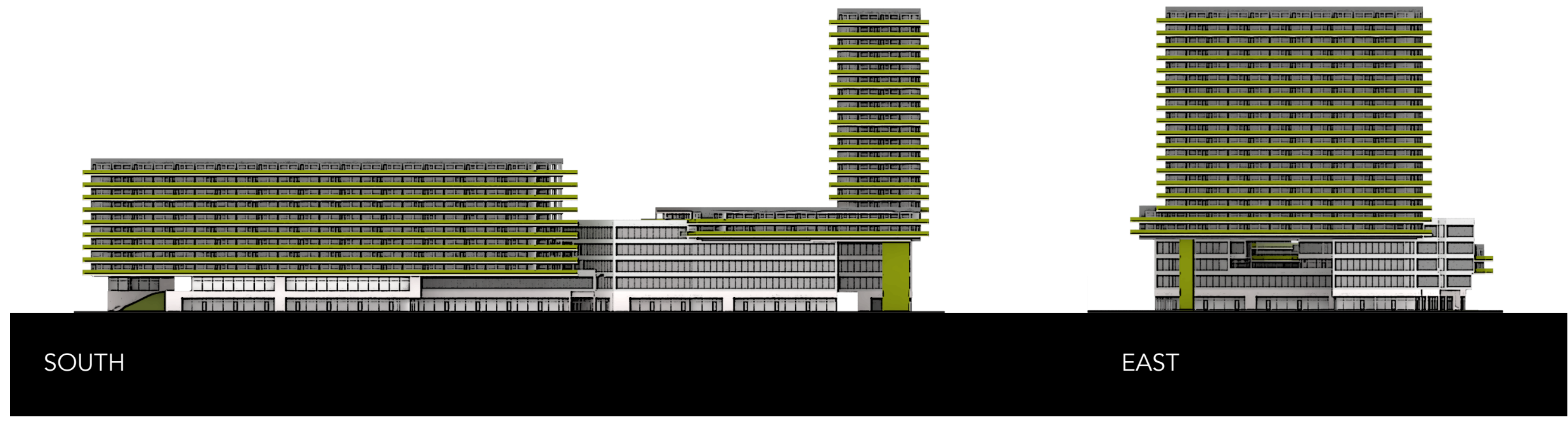



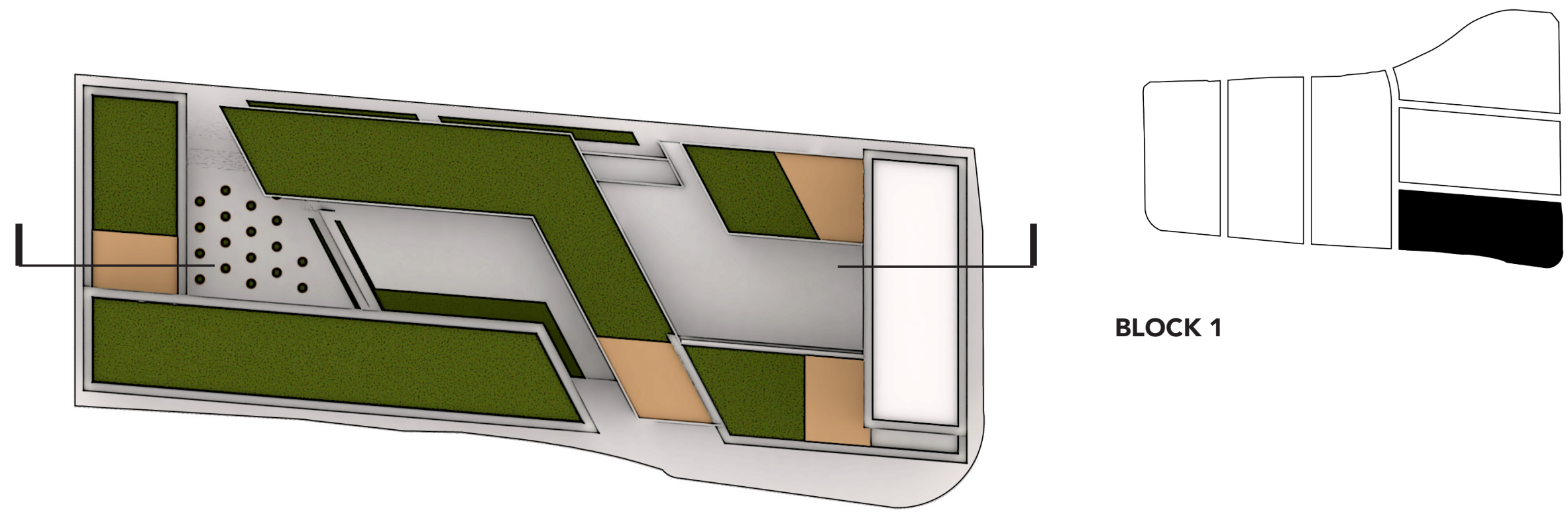

BLOCK 1

PLAN
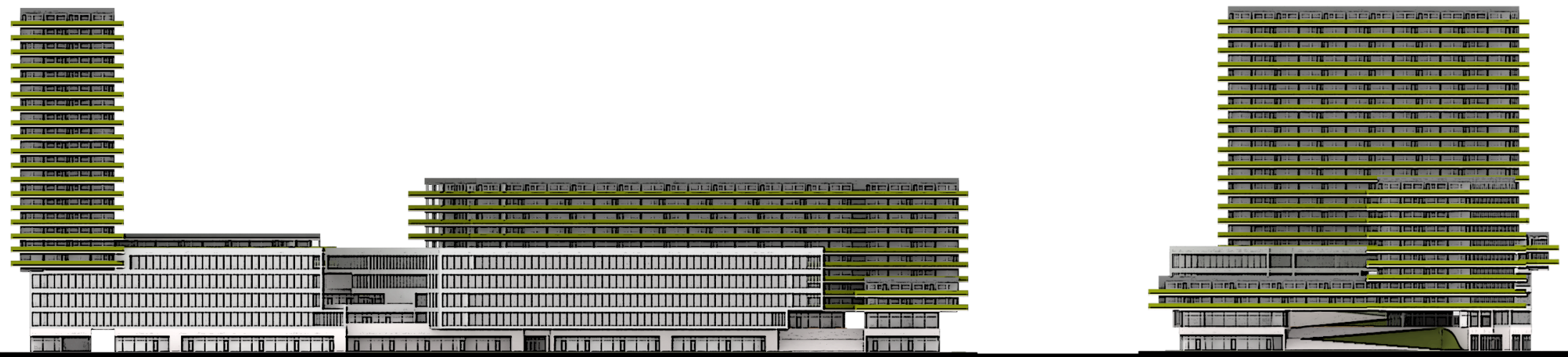

NORTH

WEST 

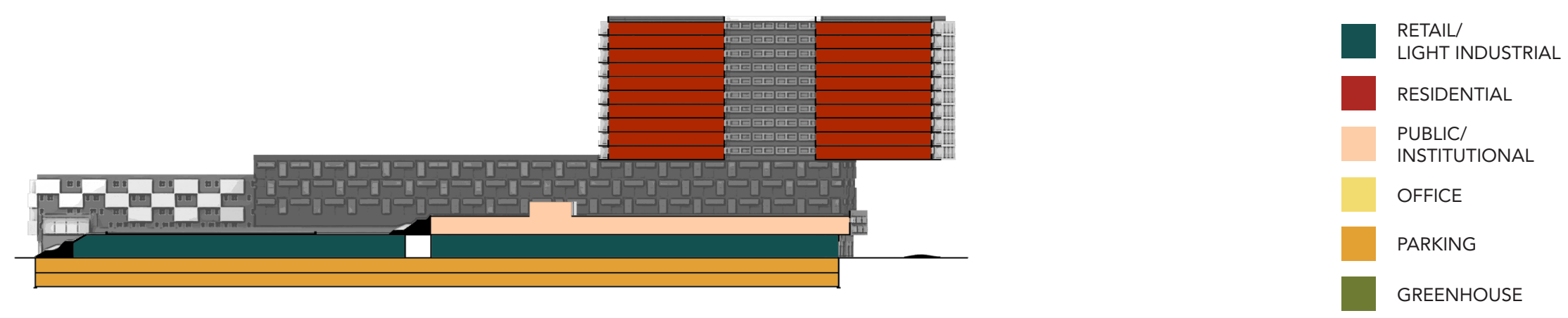

SECTION

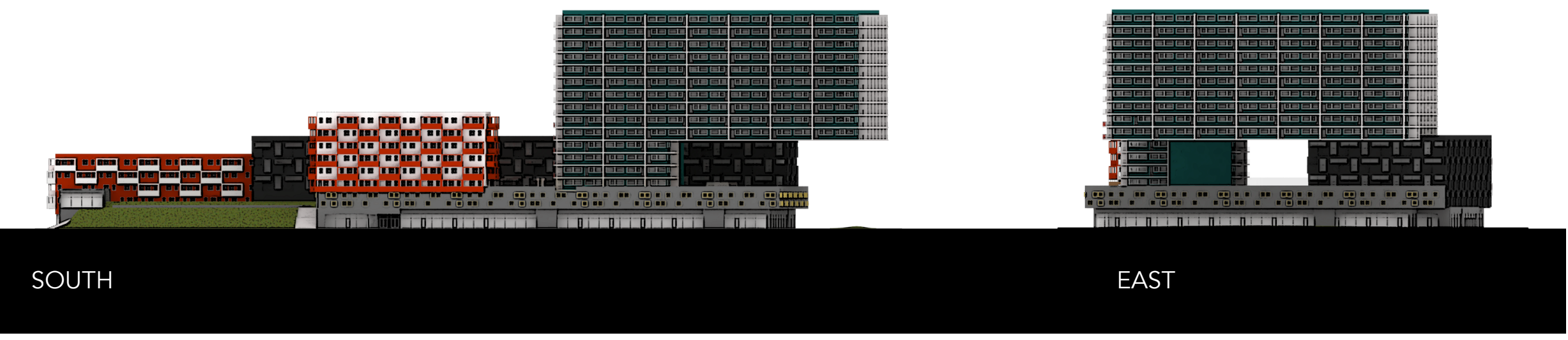



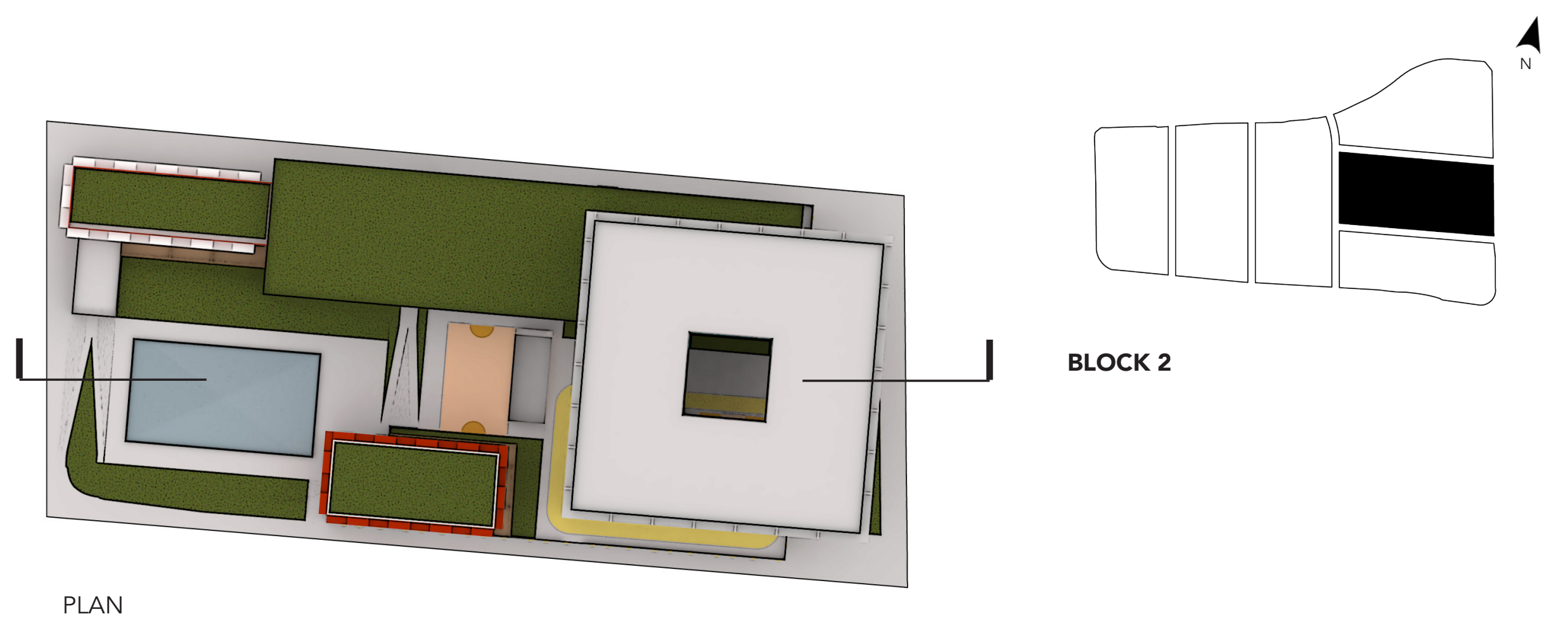

PLAN

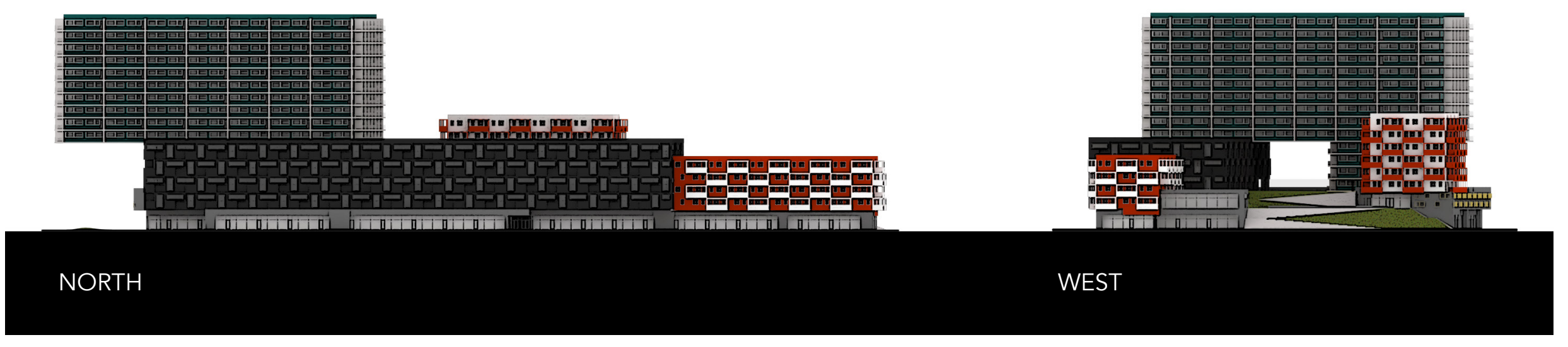



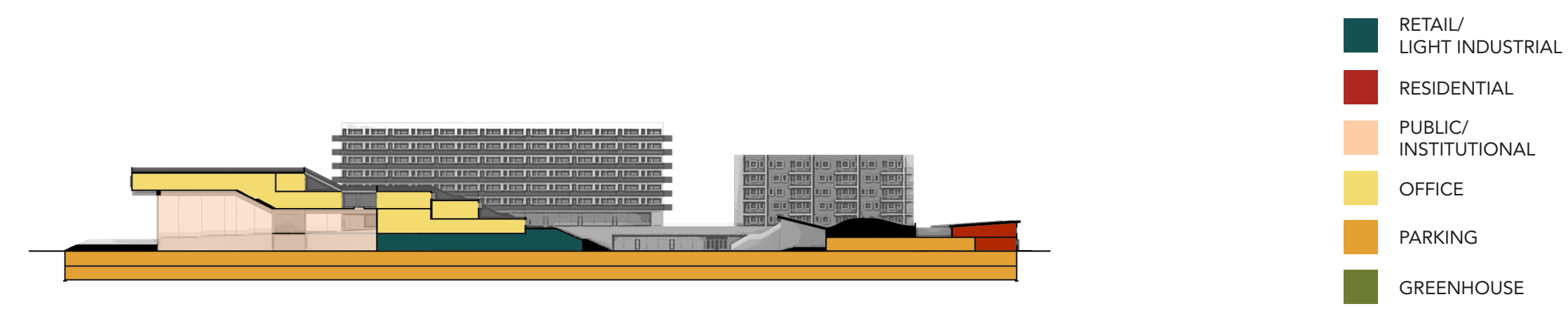

SECTION

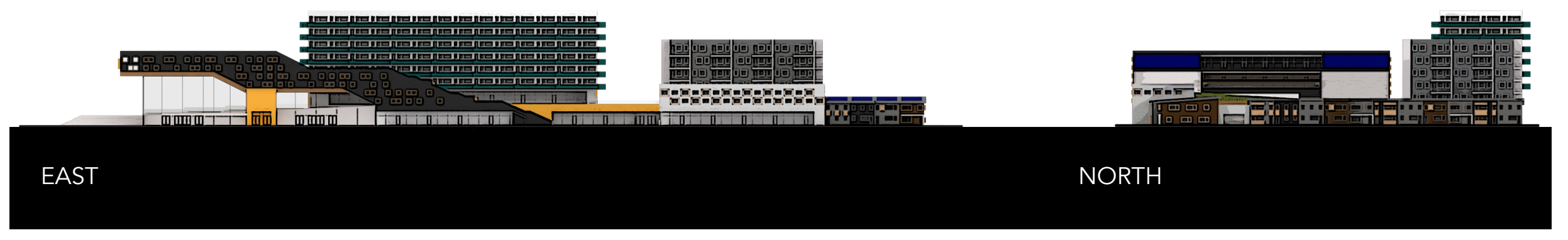



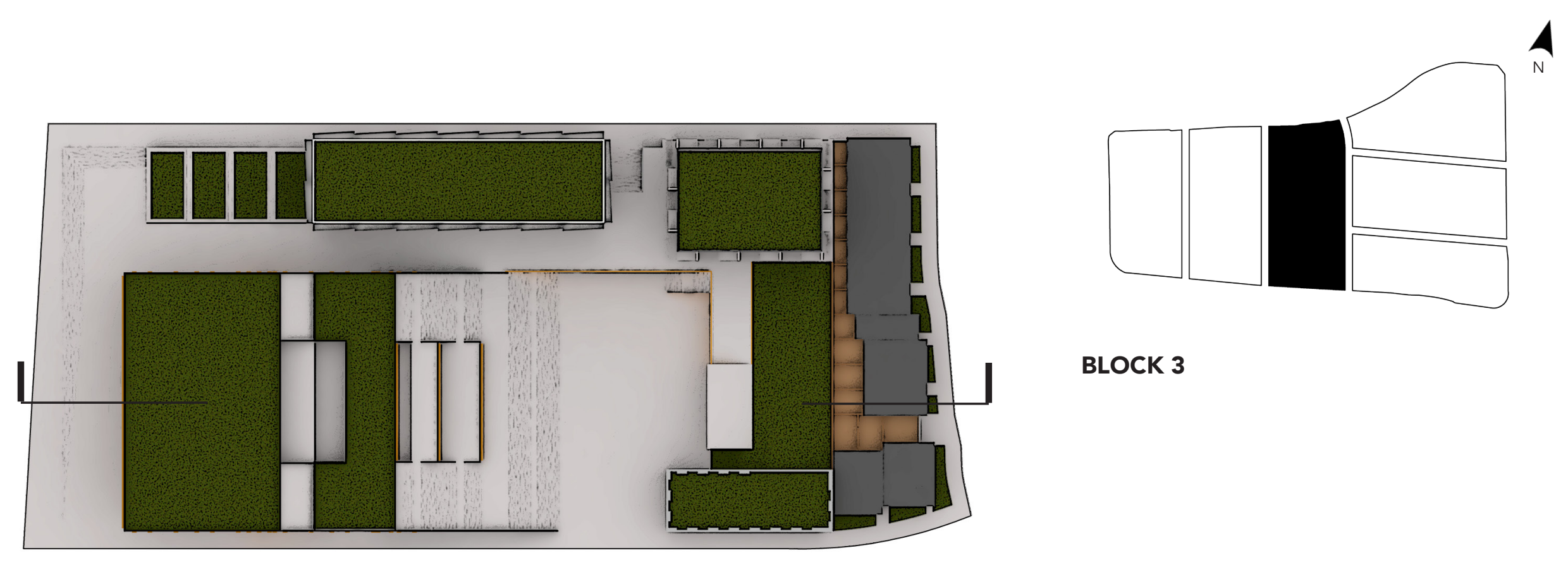

PLAN

BLOCK 3
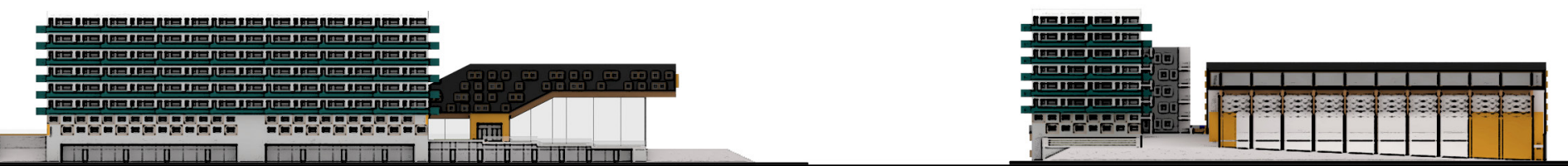

WEST

SOUTH 

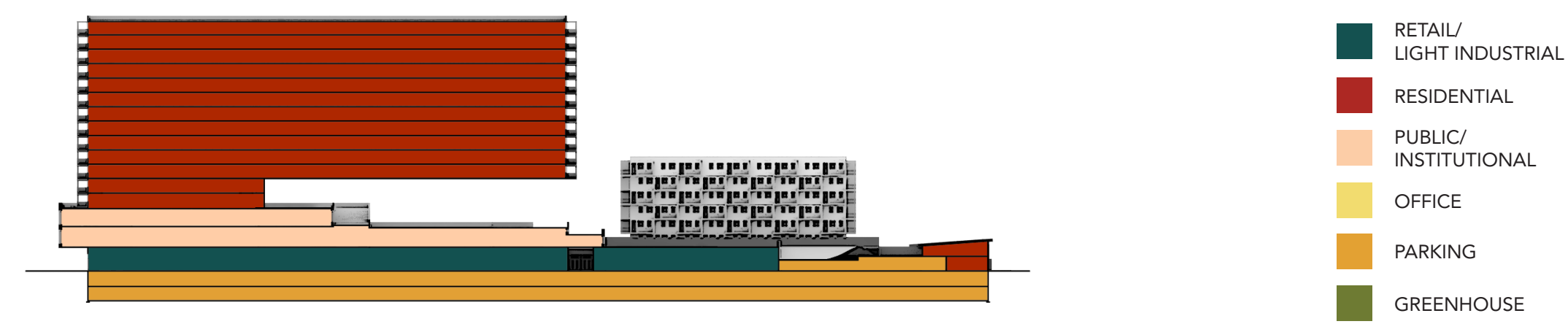

SECTION

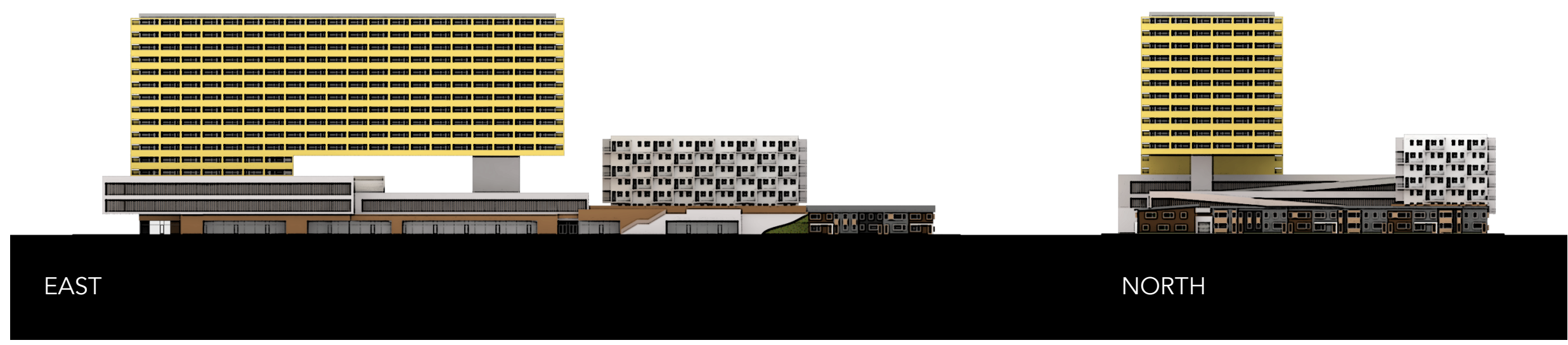



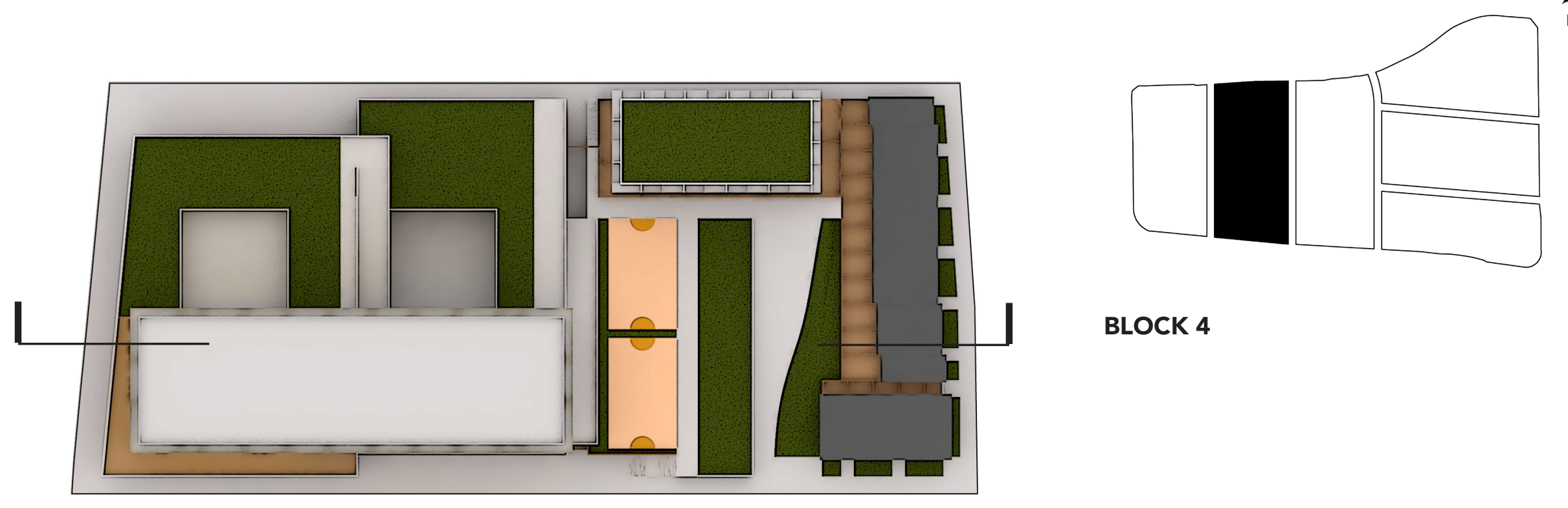

BLOCK 4

PLAN
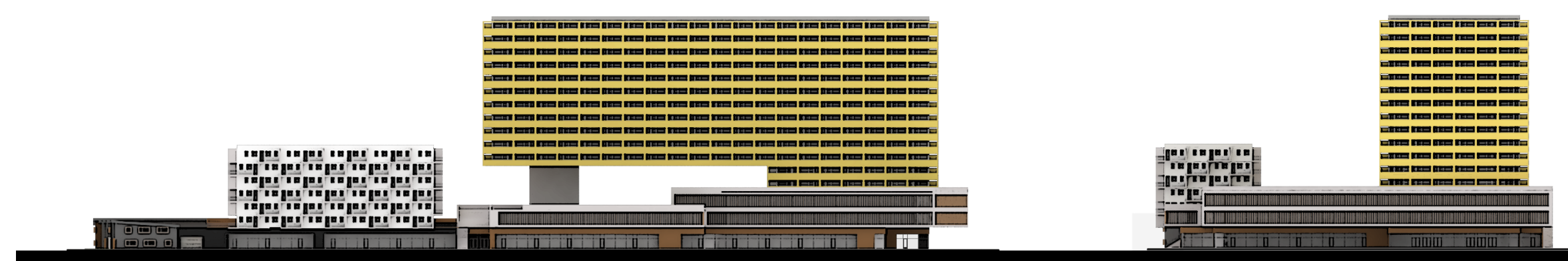

WEST

SOUTH 

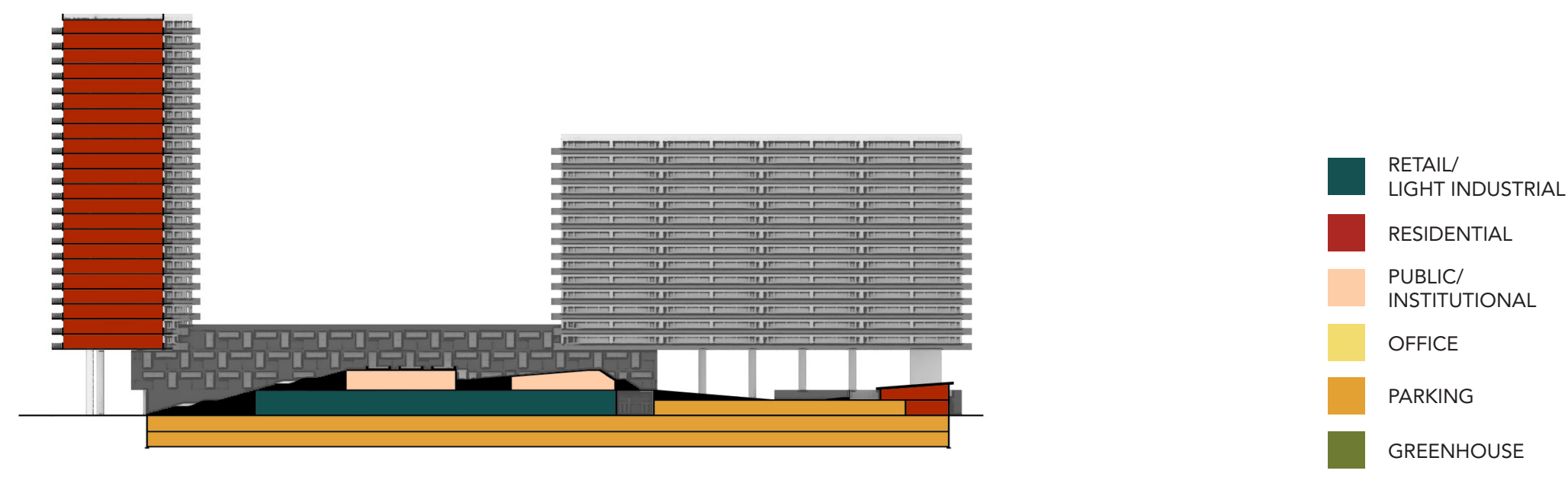

SECTION

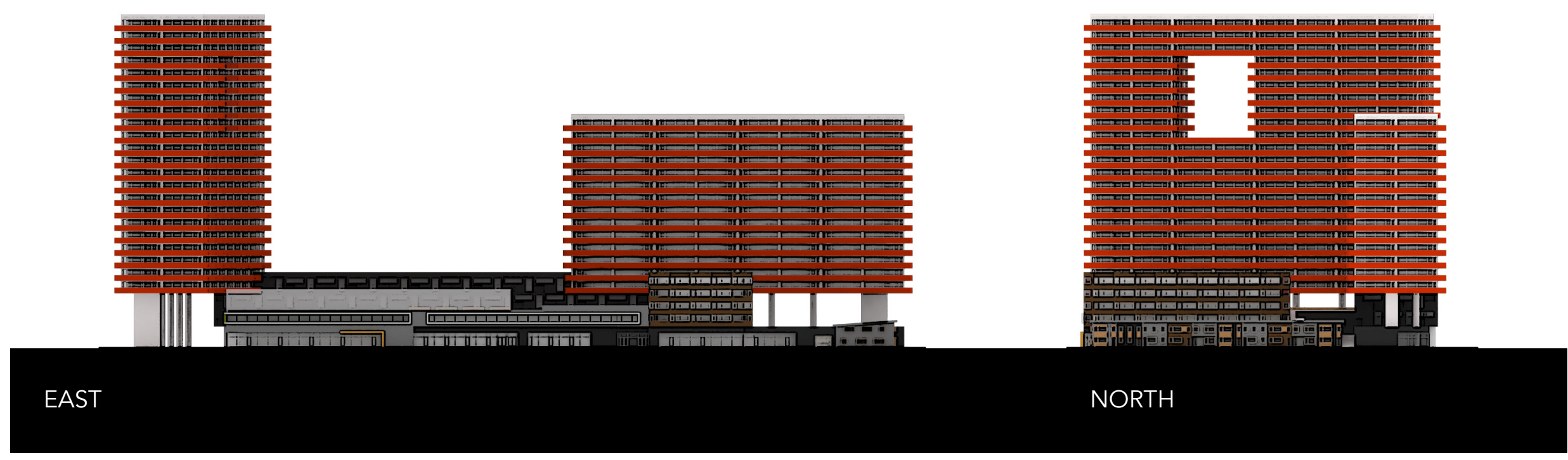



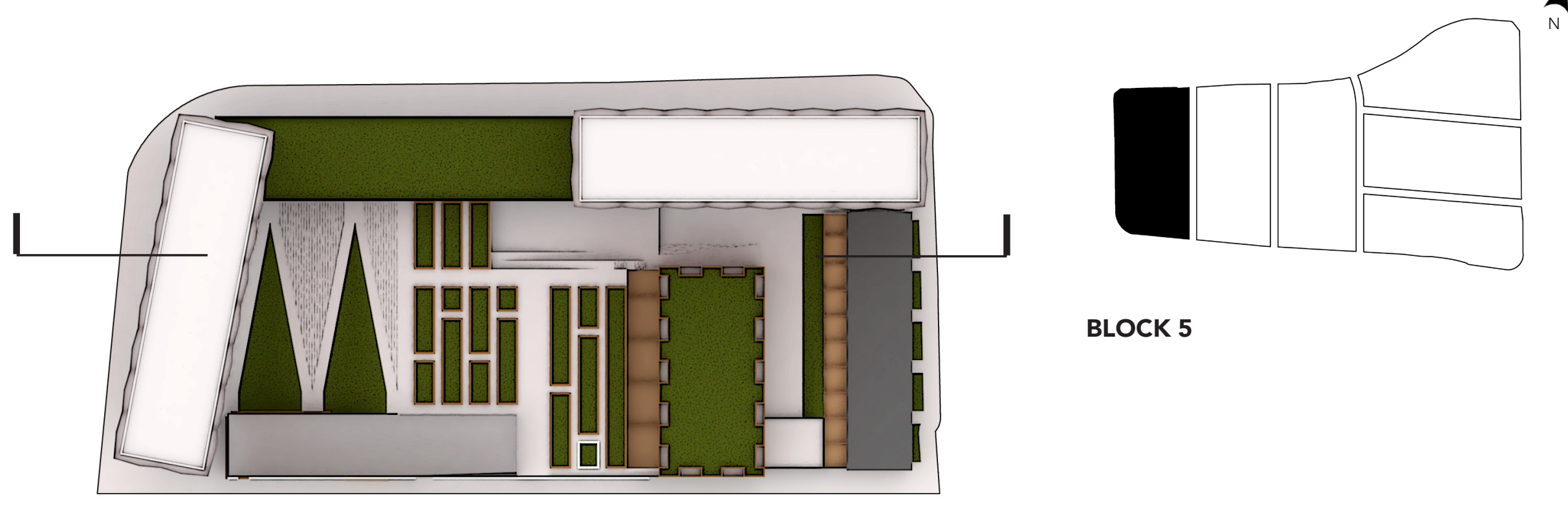

BLOCK 5

PLAN

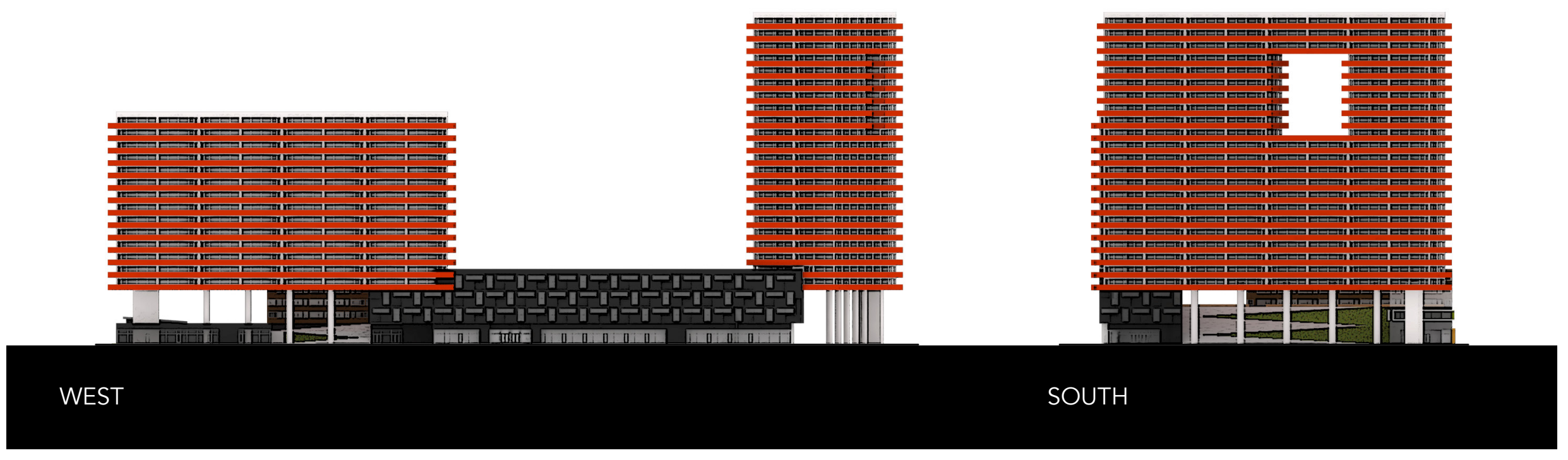


RETAIL/

LGHT INDUSTRIAL

RESIDENTIAL

PUBLIC/

INSTITUTIONAL

OFFICE

PARKING

GREENHOUSE
SECTION

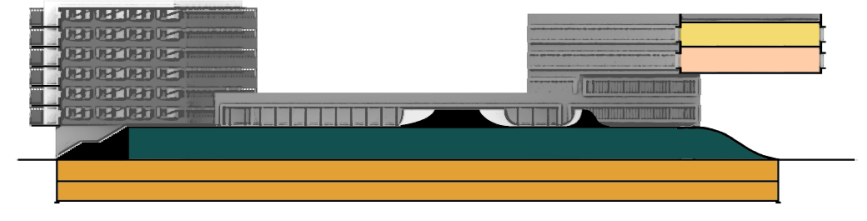



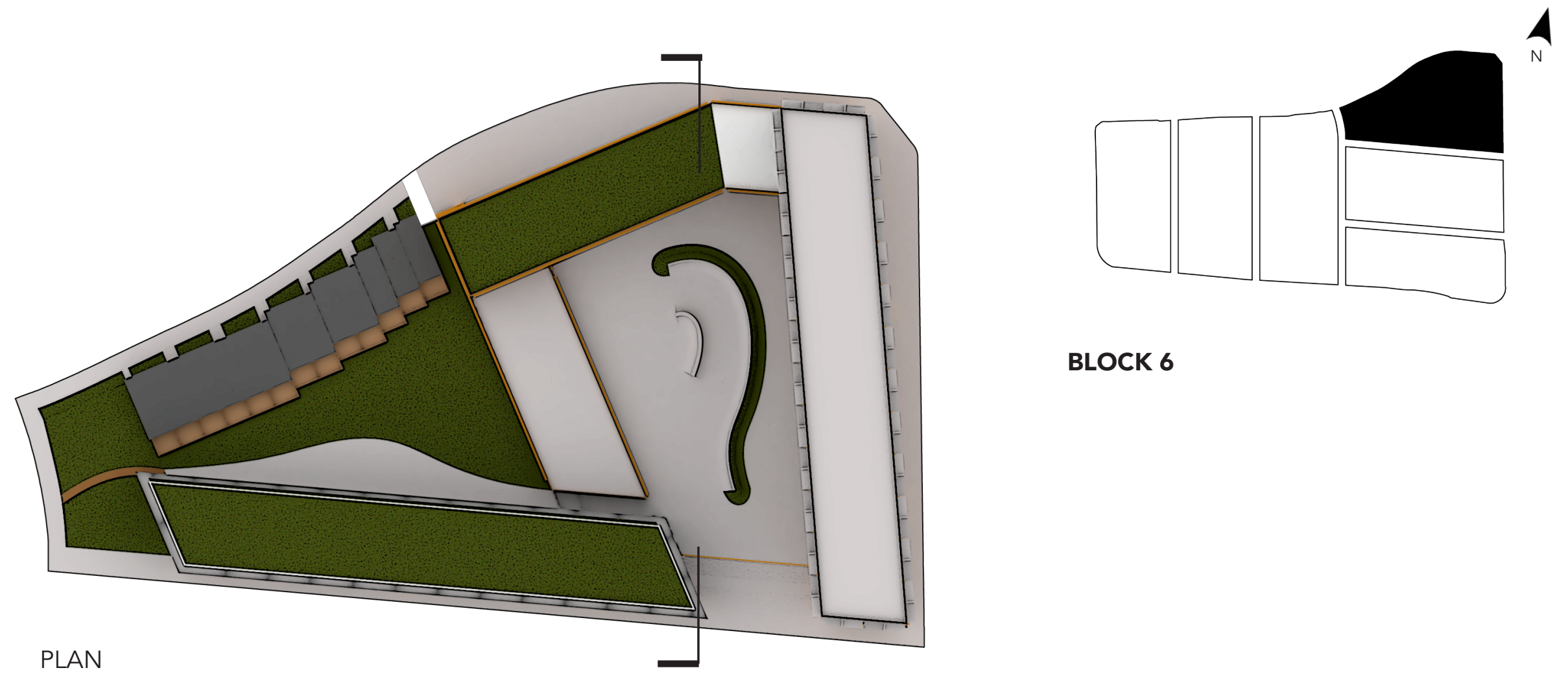

BLOCK 6

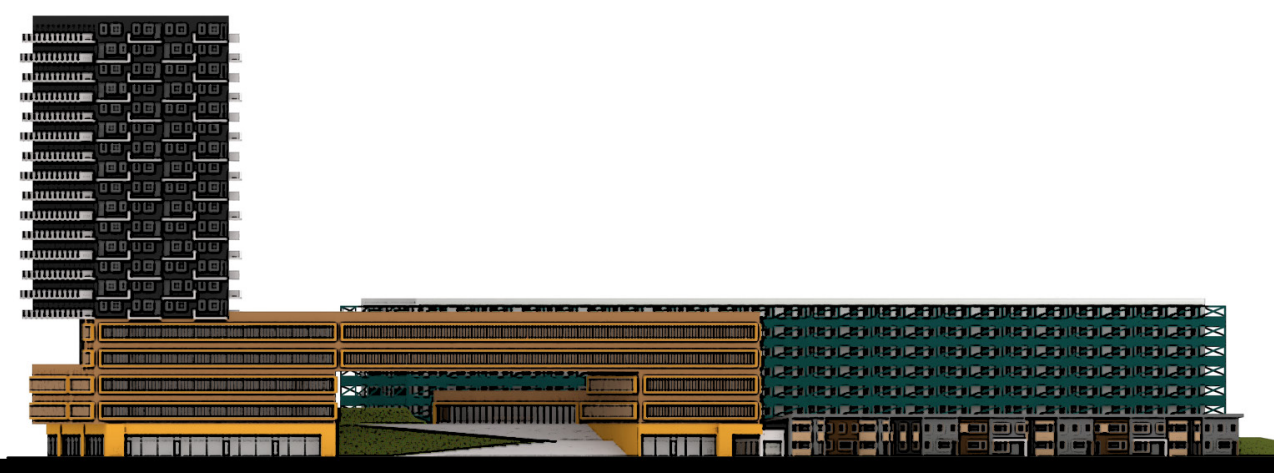

NORTH

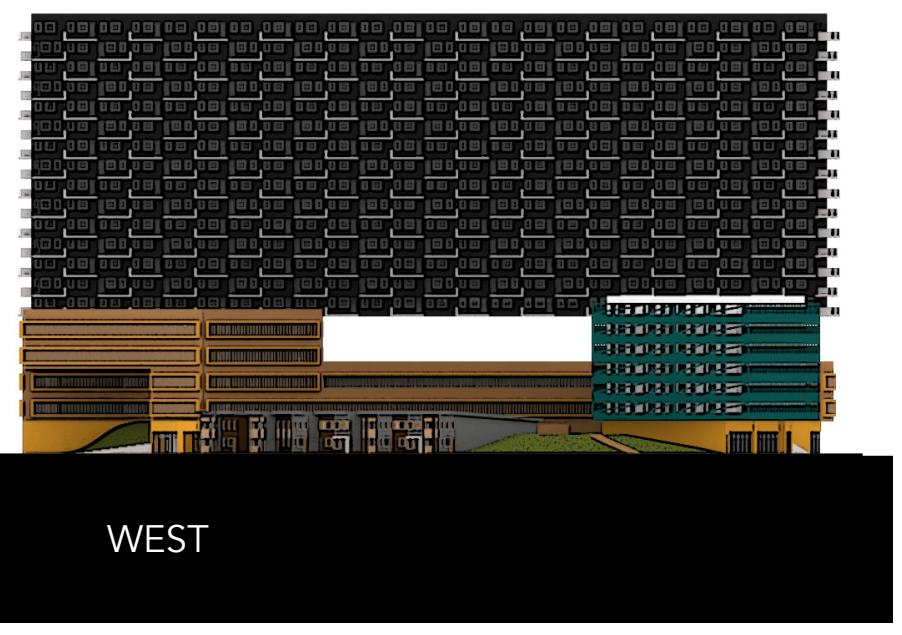



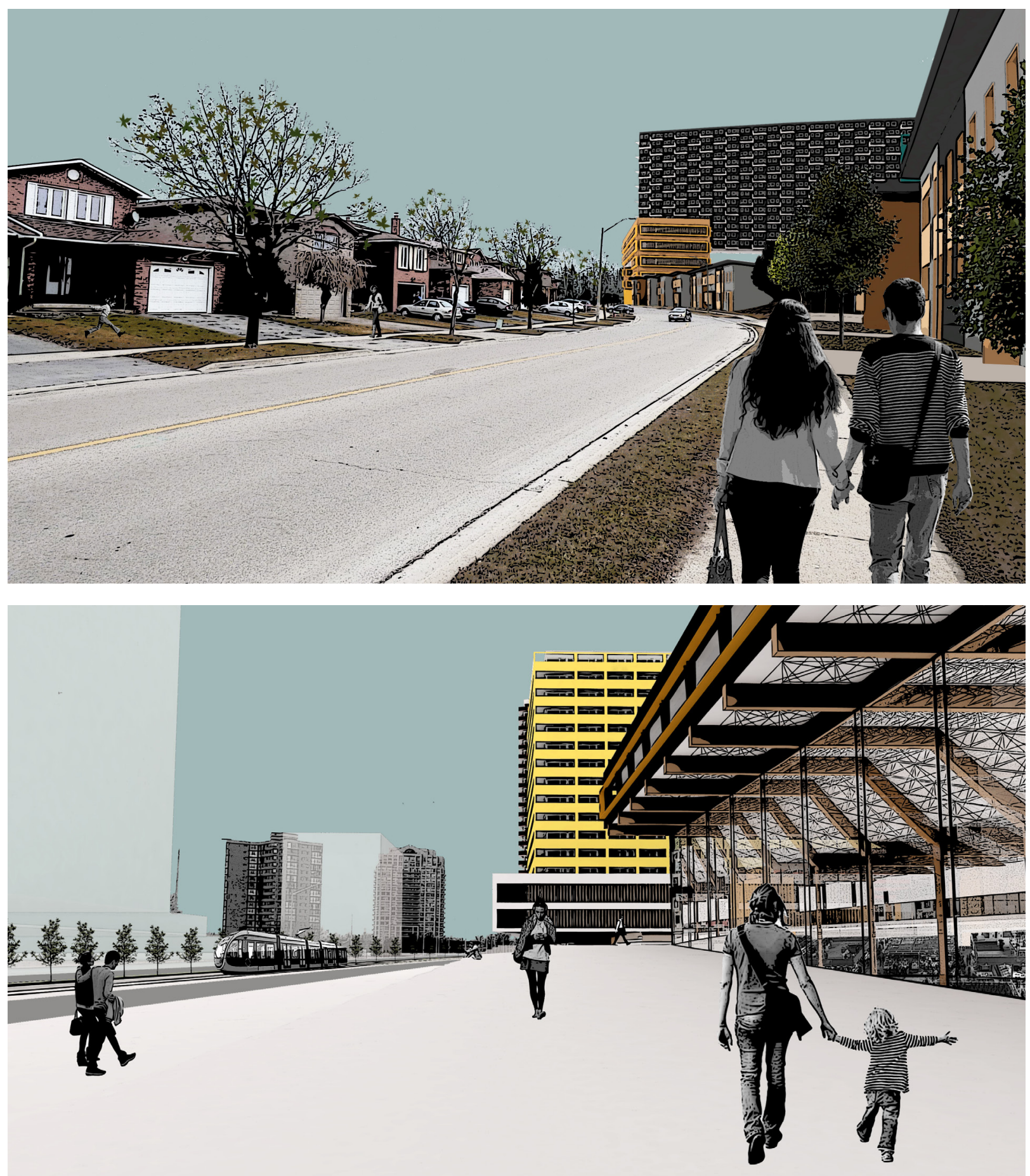

\section{STREET VIEWS}

A low-rise residential condition is maintained along Bough Beeches Blvd. with new fronting townhouses.

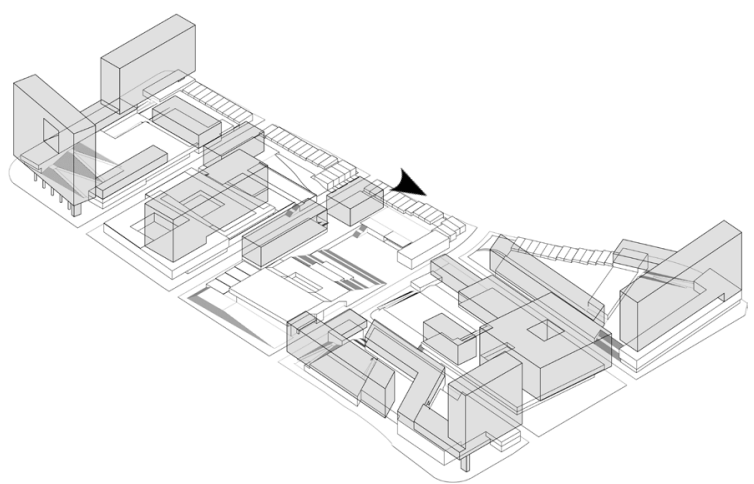

However, the environment along Dixie Road is of a much higher density, and has a more vibrant character.

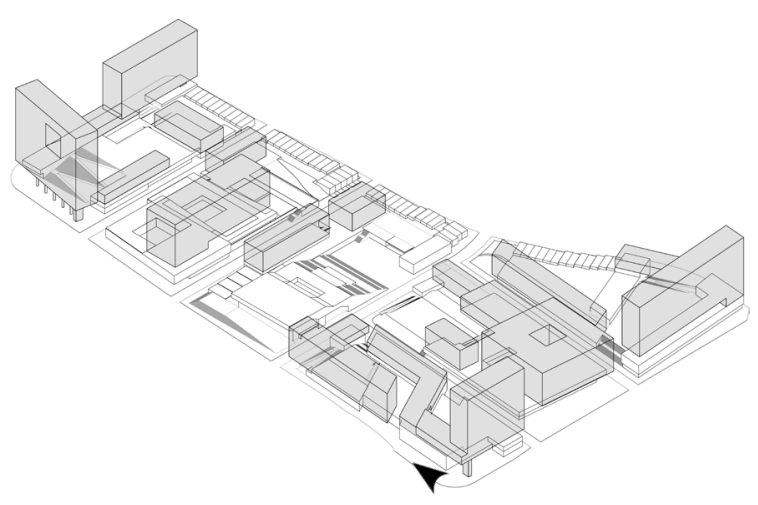




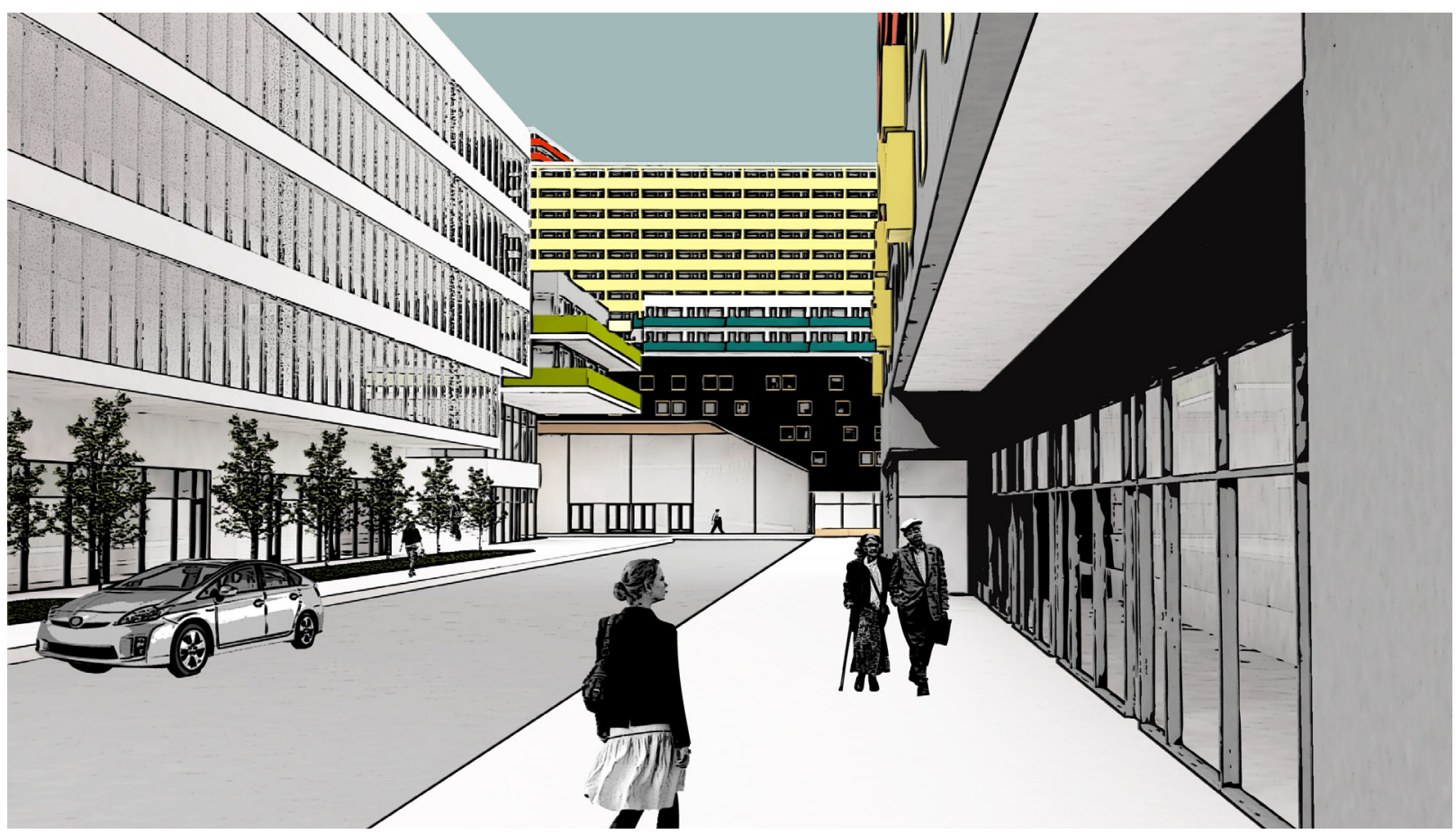

The creation of perpendicular streets creates interesting sightlines towards intersections. This view shows that the entrance to the market is highly visible.

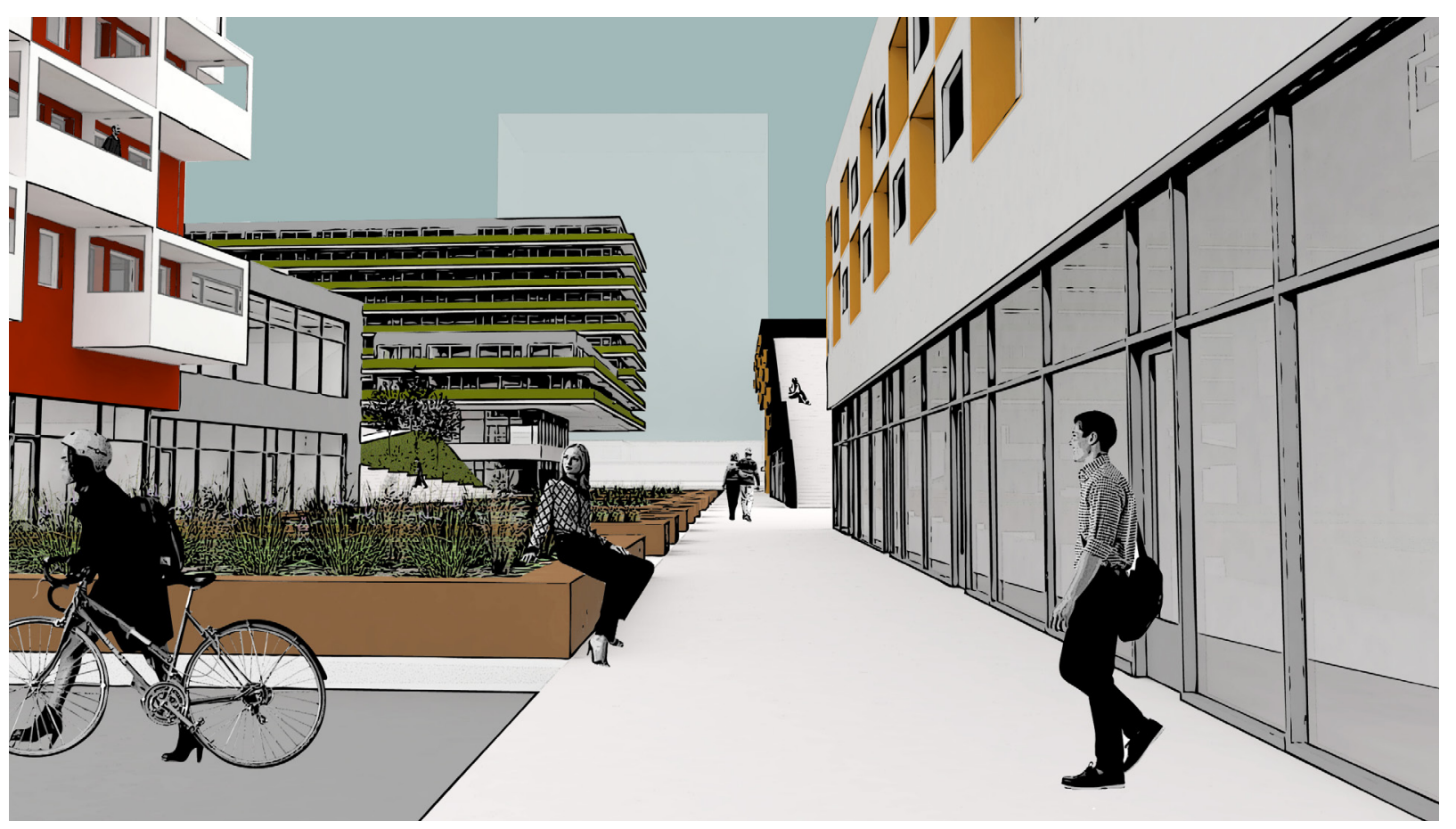

Pedestrian-only streets are formed in the centre of the urban scheme. This interstitial space allows for a stronger connection between the public spaces on Block 2 and the central plaza.

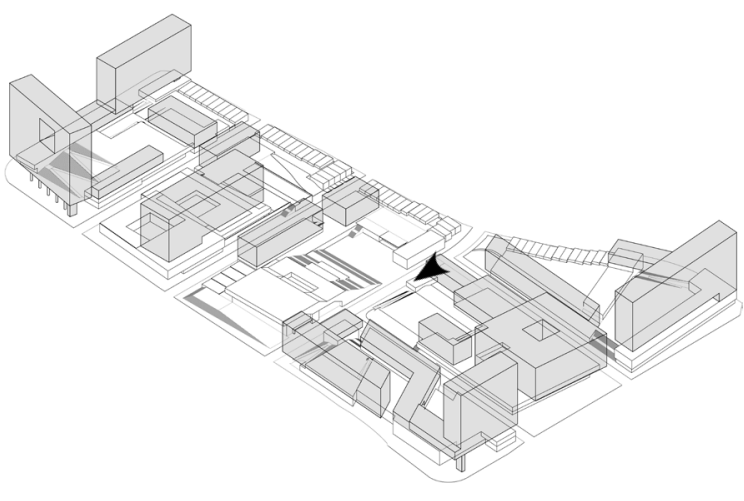




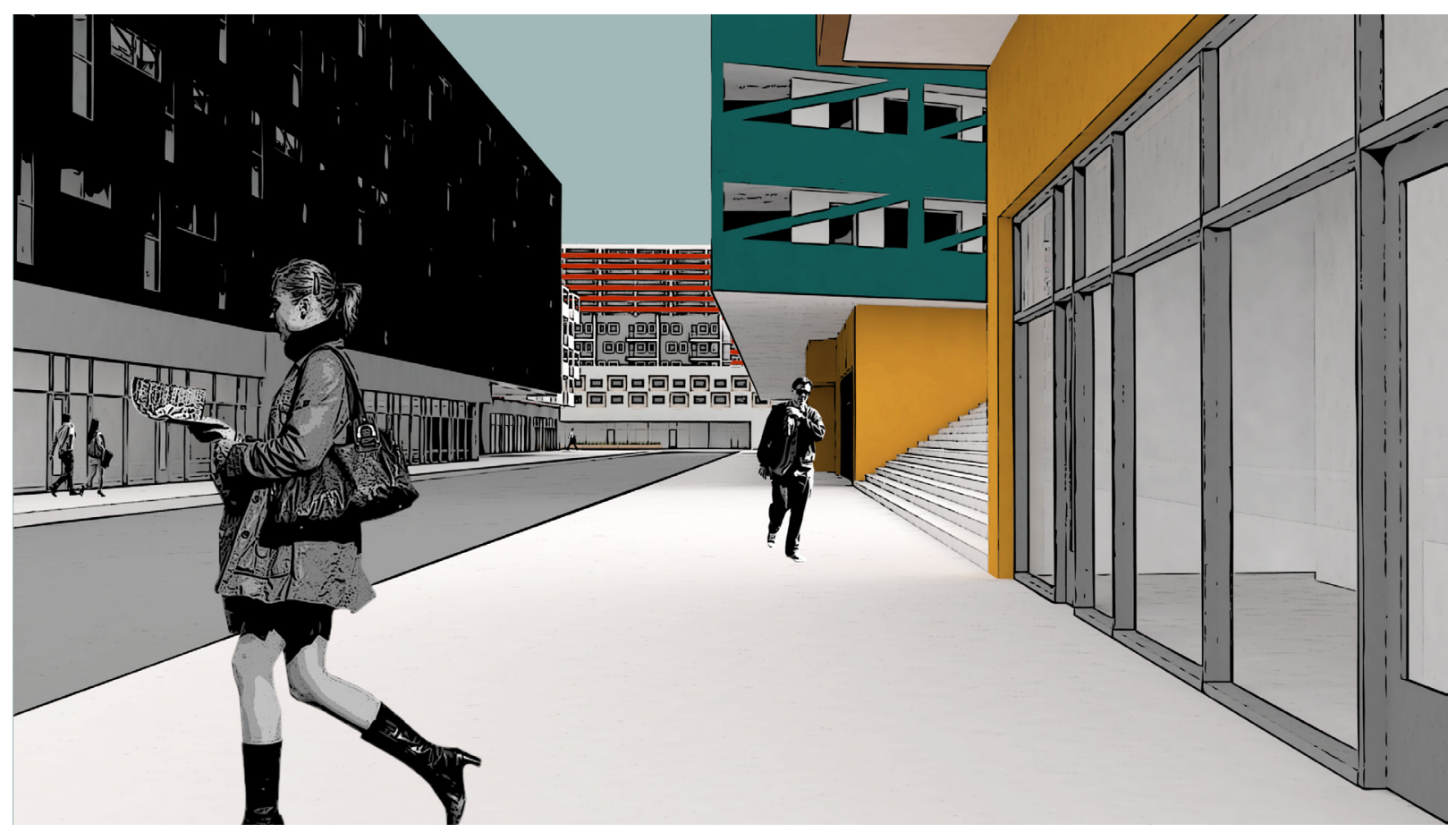

Overhangs are used to create a sense of enclosure at grade.
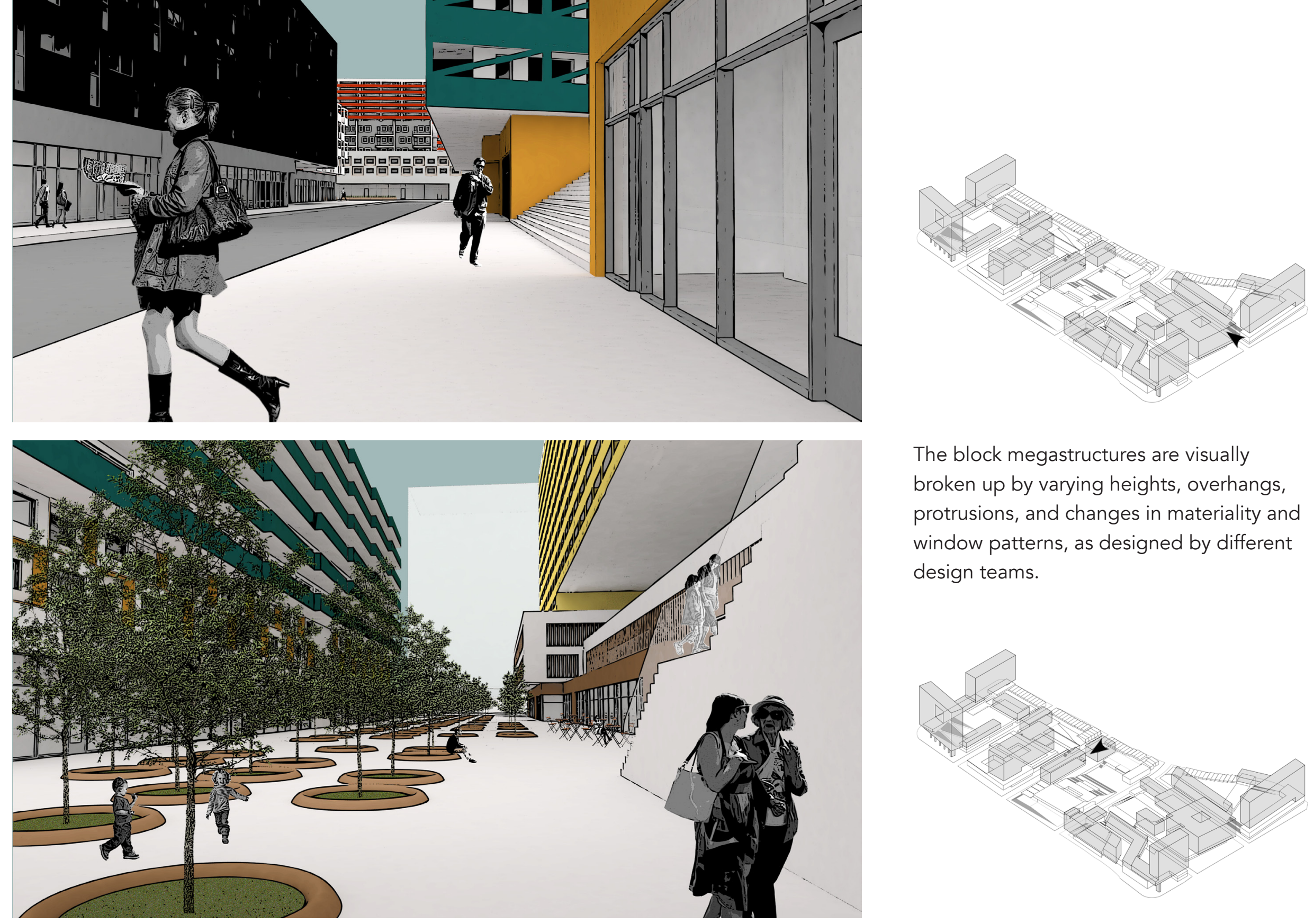

The block megastructures are visually broken up by varying heights, overhangs, protrusions, and changes in materiality and window patterns, as designed by different design teams.

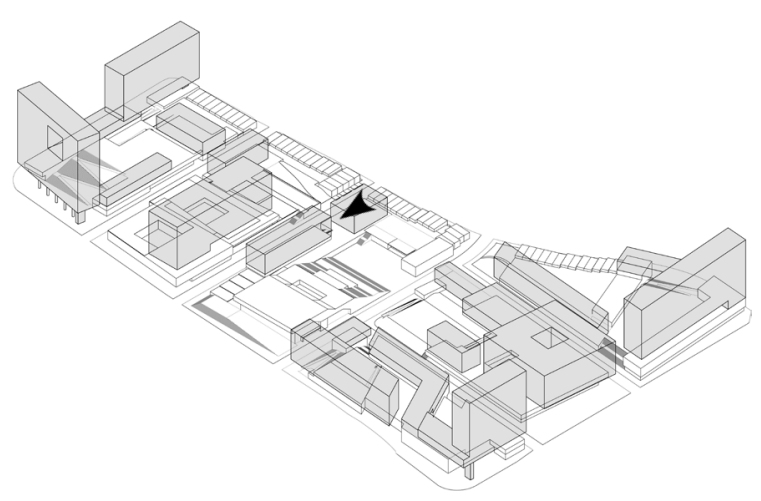




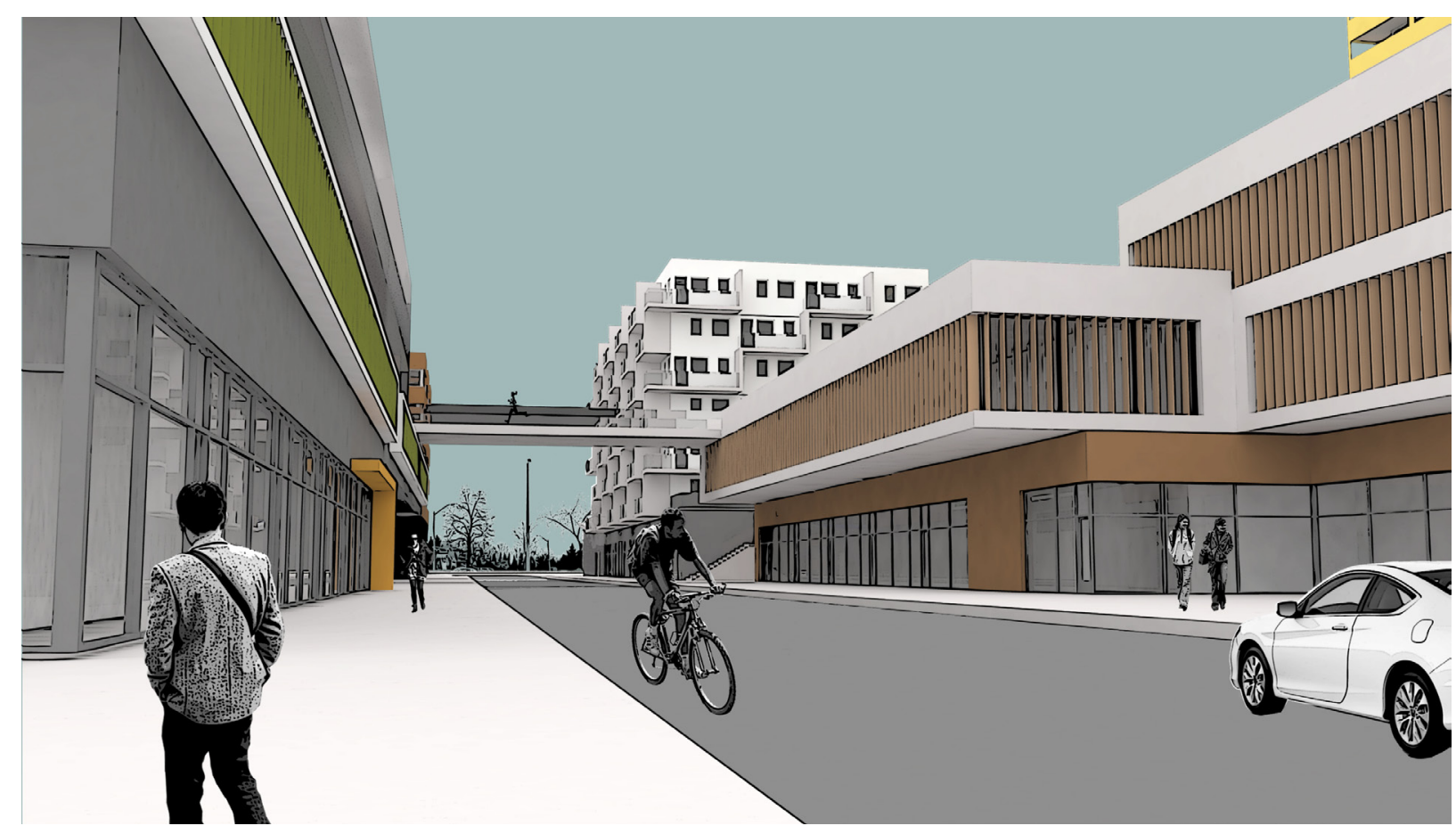

Pedestrian bridges allow for greater accessibility between urban spaces. 

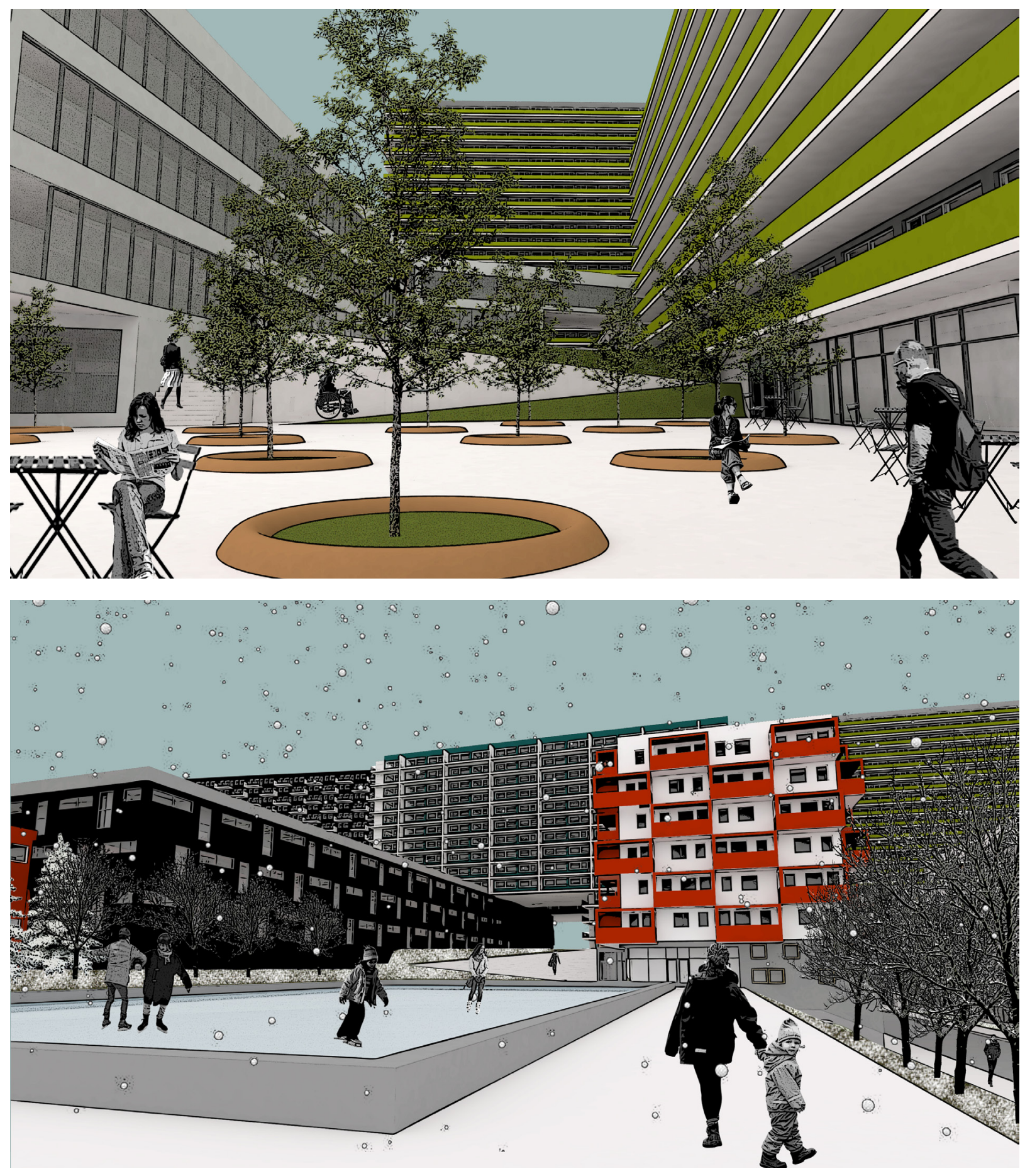

\section{URBAN SPACES}

Urban plazas are enclosed by built form, allowing for stores and restaurants to animate the space with patios, etc.

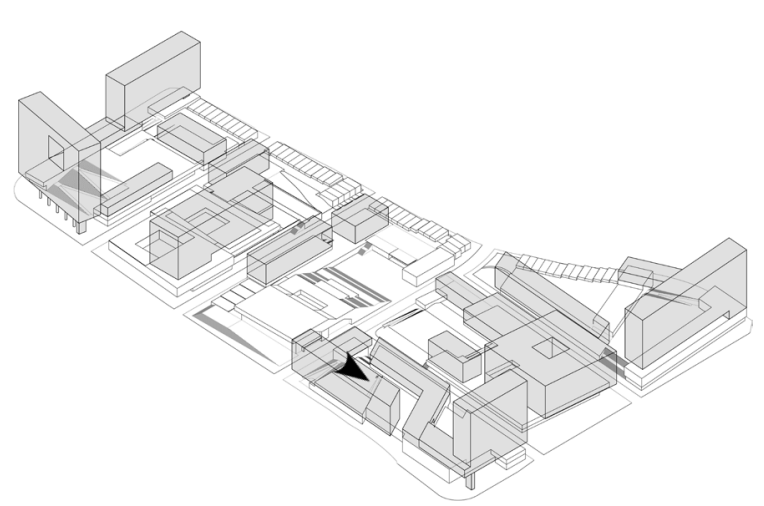

Programmed public spaces support activities suitable for multiple seasons.

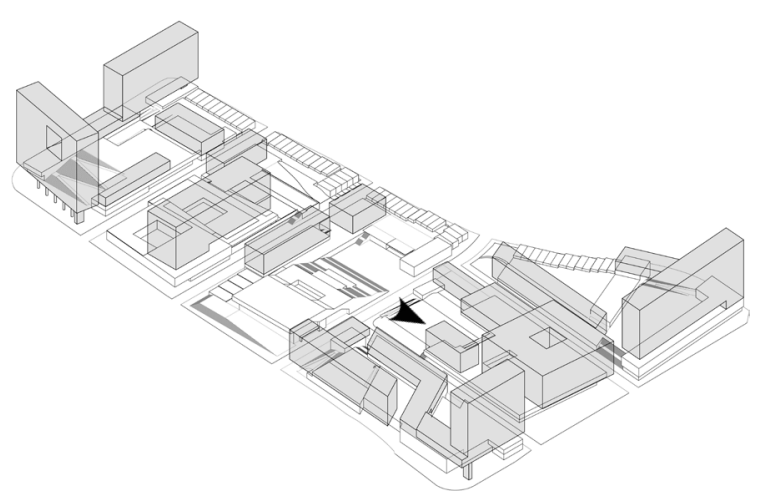




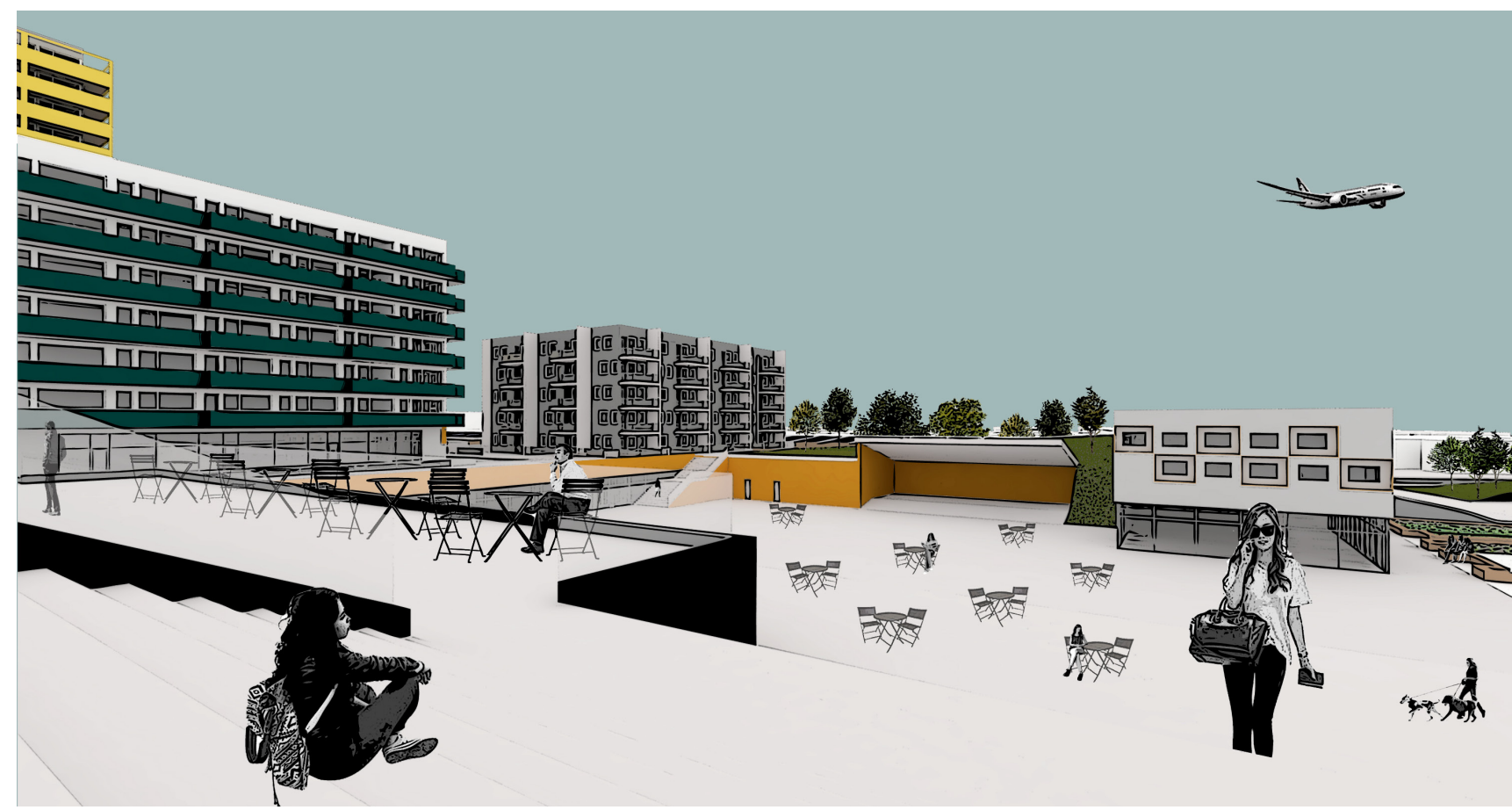

The central open space incorperates an informal amphitheatre and stage. Its at-grade location ensures that it is the most accessible and visible place in the development. The plaza could be host to multiple functions including concerts and film screenings.
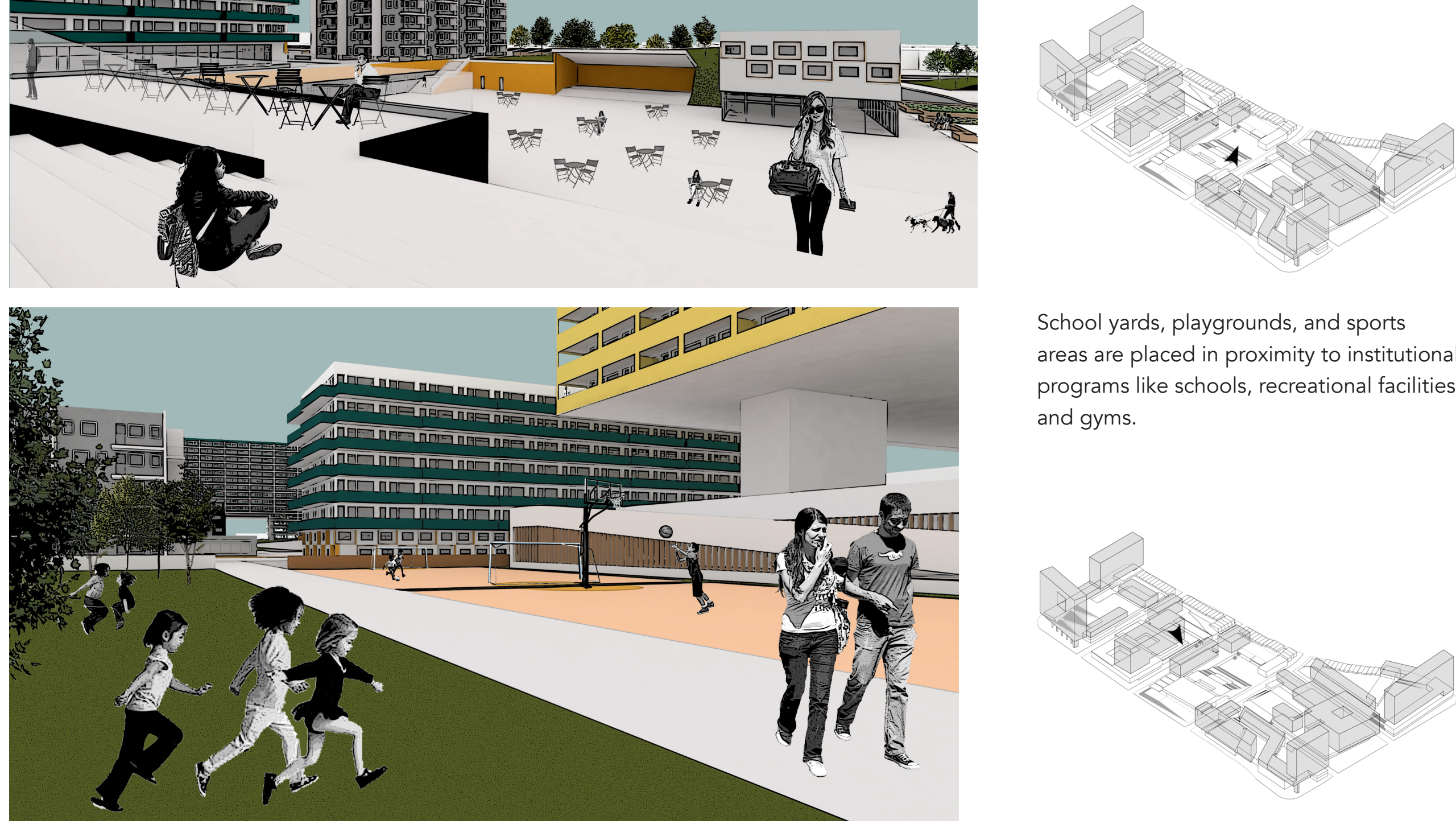

School yards, playgrounds, and sports areas are placed in proximity to institutional programs like schools, recreational facilities, and gyms.

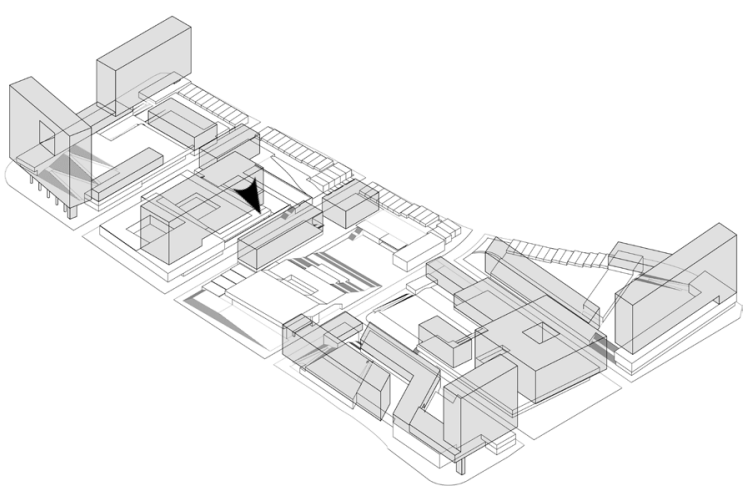



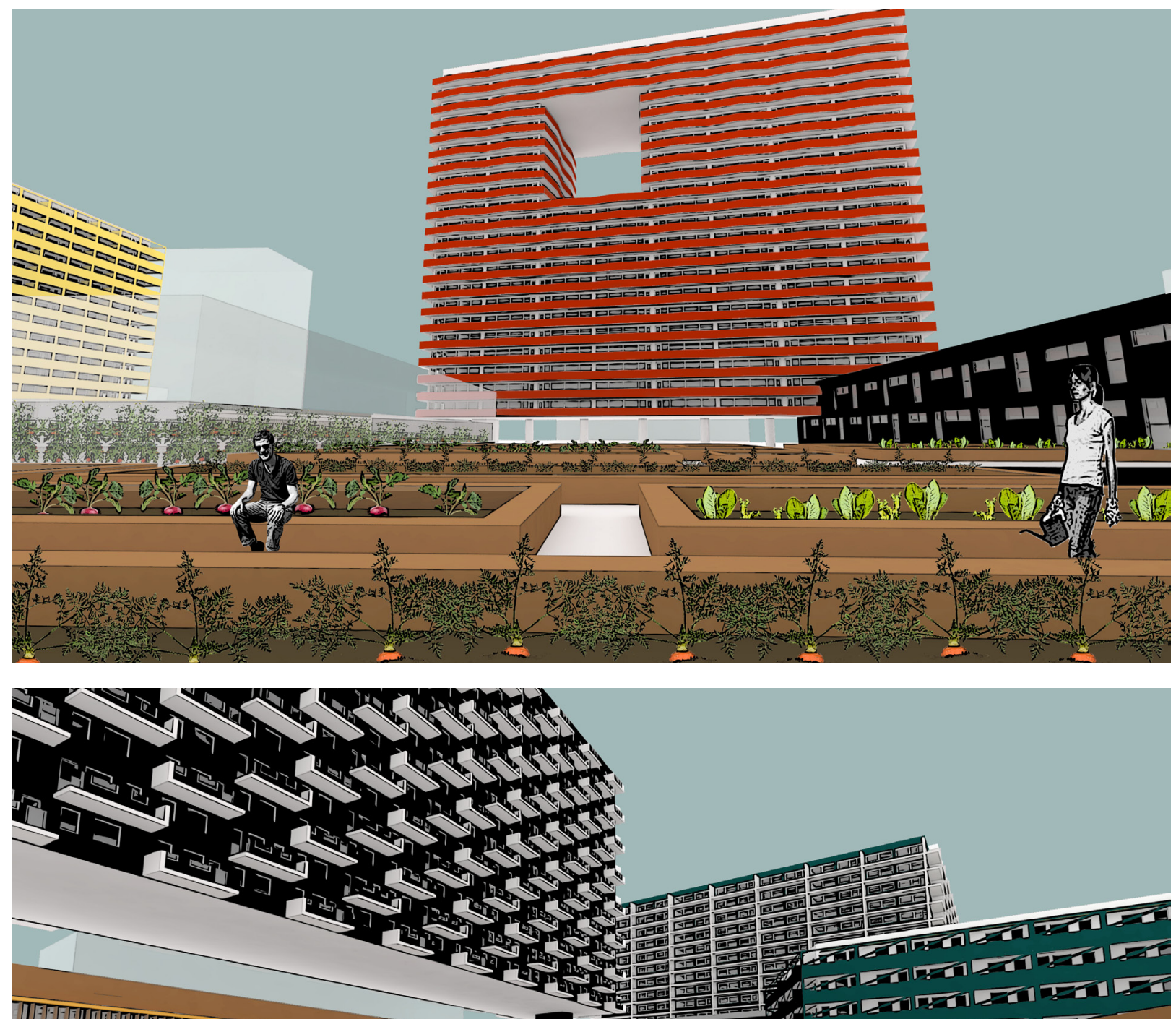

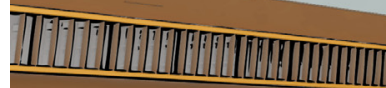

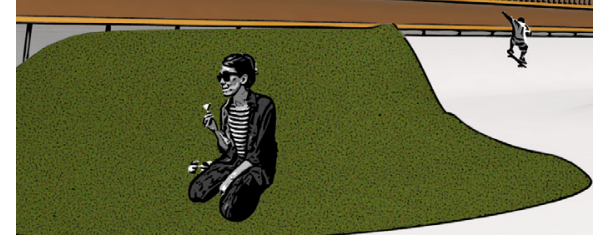

(
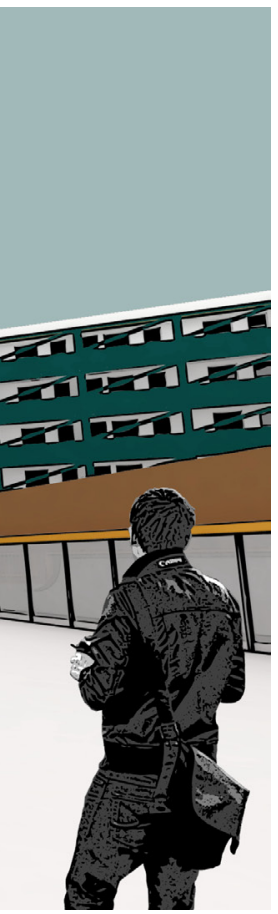

Large horizontal surfaces are utilized for urban farming wherever sunlight permits.

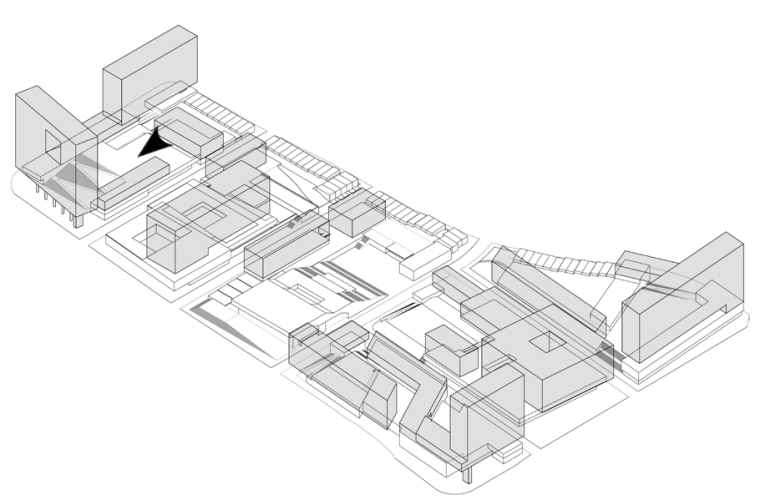

Programmed urban spaces such as skateboard parks create social spaces for teenagers.

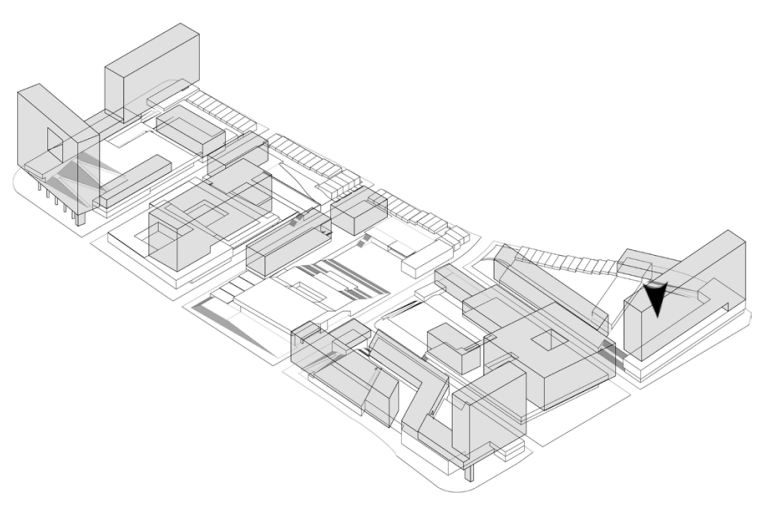



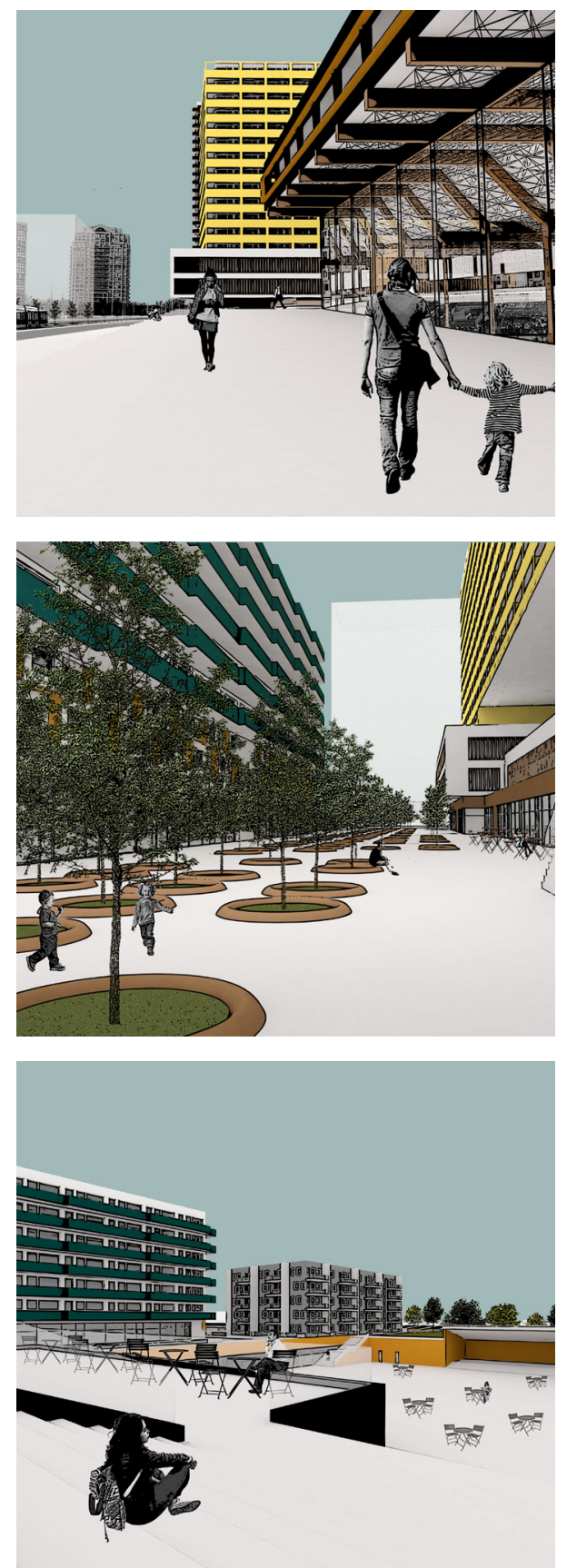
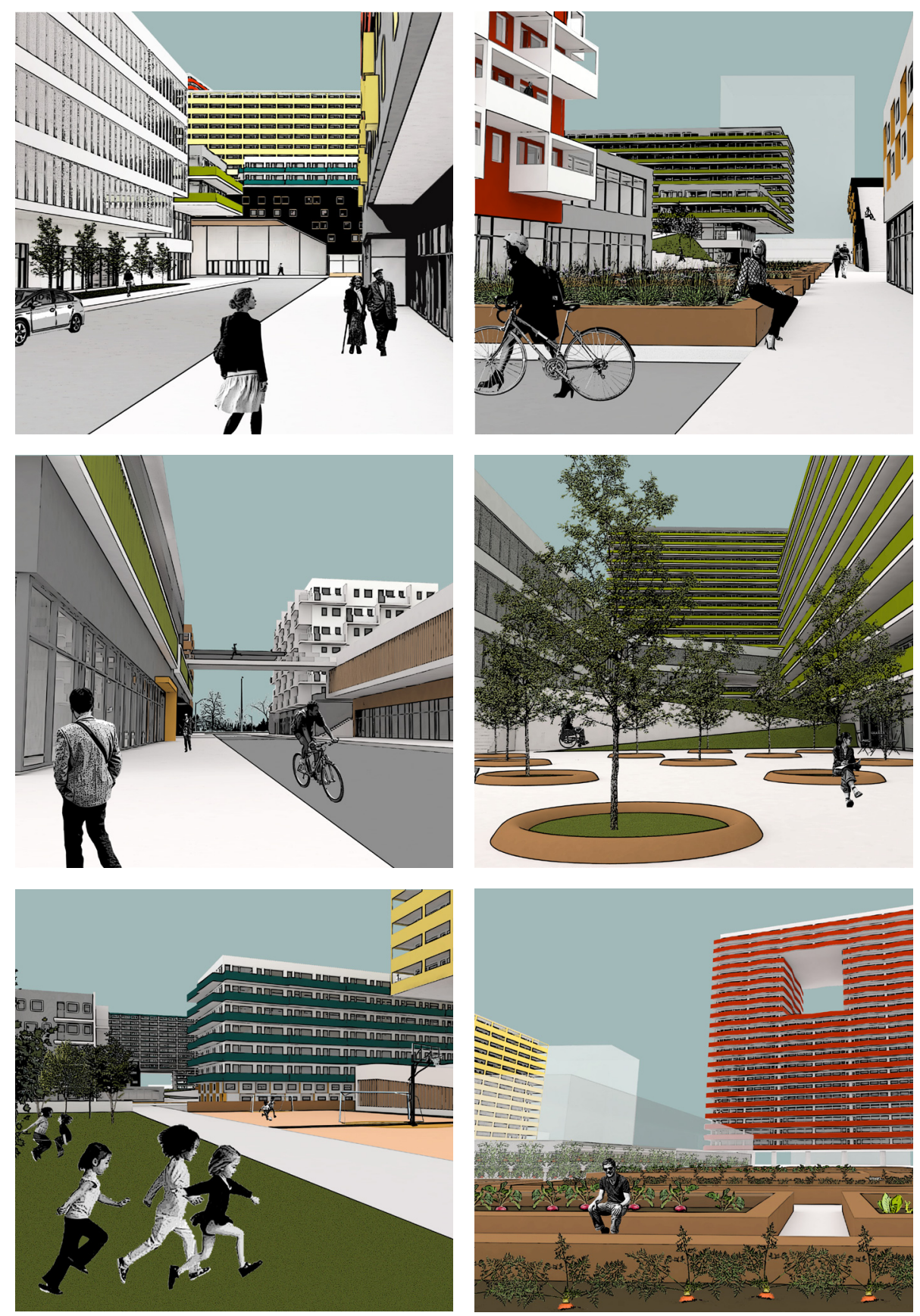
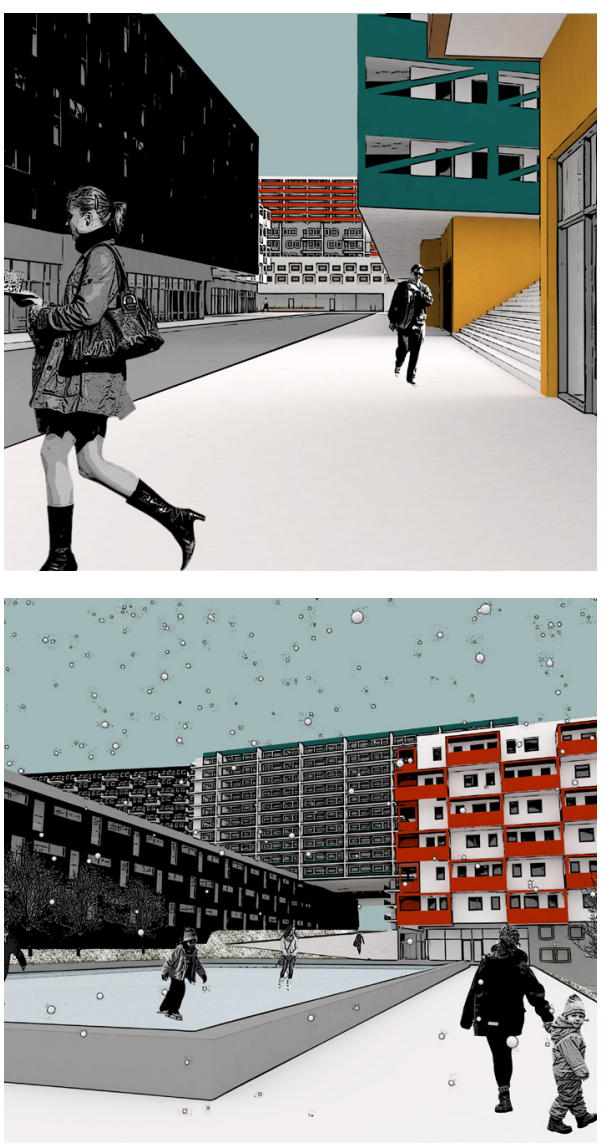


\section{CONCLUSION}

Ultimately, this scheme provides a series of identifiable urban places, and a transition between the private and the public realm. It does not deny the inherent modernity of suburbia, but rather, it embraces it as a method to foster a sense of place. This project is a case study for all potential cores in postwar suburbs. Each condition would be unique, but these strategies could be reinterpreted and evolved as necessary. In this way, designers can transform suburbia from the inside out, by allowing it to evolve from its own framework.

The central objective of the thesis has been to reopen and reexamine the discussion of the role of architecture in defining urban places. Master planning (by architects) has long been associated with the apparent failures of orthodox modernism - largely its failure to create identifiable and interactive places. This should not be a reason to abandon master planning. It should be an opportunity to evolve the process to respond to a contemporary condition.
As urban populations continue to rise, inevitably we will need to keep building 'big.' As urban areas become increasingly populated, the previously overlooked modernist suburbs will become the new canvas for design explorations. In this way, the transformed cores of suburbia could once again become manifestations of modernity.

Overall, the subtitle of this thesis could be 'a study in dealing with bigness.' Postwar suburbia is vast and sprawling. It is itself big. Thus, an architecture of intervention must respond to this reality. As this thesis has made clear through its research and design iterations, bigness is certainly a challenge. And the design response much always be critical and evolving. But as our world continues to modernize, the challenge to 'make no little plans' should certainly not be abandoned. 


\section{"Make no little plans; they have no magic to stir men's blood"}

Daniel Burnham (1907) 


\section{IMAGE CREDITS}

\section{INTRODUCTION}

Figure 1: [Left] Metropolitan Life Advertisement via Envisioning the American Dream. Digital image. Treehugger. March 25, 2016. http://www.treehugger. com/urban-design/burbs-are-back.html. [Right] Seton Louisa. Digital image. http://www.louisaseton.com. au/filter/lifestyle/Lifestyle-Urban.

Figure 2: Image created by author

Figure 3: Mississauga City Centre as seen from Burnhamthorpe Rd at Dixie Rd, Mississauga, Ontario. Personal photograph by author. March 13, 2016

Figure 4: Digital Image created by author. Information from City of Mississauga. "Schedule 6: Long-Term Transit Network." Digital image. http:// www6.mississauga.ca/onlinemaps/planbldg/MOP/ Schedules/6-TransNetCntre_V8.pdf.

\section{PART 1}

Title page: Early Housing Development, Levittown, N.Y. 1954. Bettmann Archive, Corpis Images. http:// www.britannica.com/place/Levittown-New-York.

\section{CHAPTER 1.1}

Figure 1: Howard, Ebenezer. Diagrams. In Howard, Ebenezer. "The Garden Cities of To-Morrow." In Department of City and Regional Planning, Cornell University, by John W. Reps. Ithaca: Cornell University. http://urbanplanning.library.cornell.edu/DOCS/ howard.htm.

Figure 2: Diagram of Clarence Perry's Neighbourhood Unit. Digital image. Wikipedia. April 19, 2011. https:// en.wikipedia.org/wiki/File:New_York_Regional_ Survey,_Vol_7.jpg.

New York Regional Survey, Volume 7, 1929.

Figure 3: Plan of Radburn, NJ. Digital image. Zoning the Garden State. October 1, 2013. https:// zoningthegardenstate.wordpress.com/2013/10/01/ radburn-new-jersey-a-model-town/.

Figure 4: Stein, Clarence. Toward New Towns for America. Reinhold Publishing Corporation: New York. 1957. LCCCN 57-6538

\section{CHAPTER 1.2}

Figure 1: A Photograph from Levitt and Sons Brochure. University of Illinois at Chicago. http://www. oldhouseweb.com/blog/levittown-the-houses-thatspawned-a-community/.

Figure 2: Murray, Edna. New Residents Move into Their Homes in Levittown on Wednesday, Oct. 1 1947. October 1, 1947. Levittown Public Library, Levittown, NY. http://www.newsday.com/long-island/ long-island-in-the-1940s-1.3599253\#45.

Figure 3: Digital Image created by author

Figure 4: Moltke, Willo von. Sketches. in Joseph Hudnut, "The Art of Housing," Architectural Record 93 (January 1943): 63

Figure 5: Southdale Mall, 1956. Minnesota Historical Society, Edina, Minnesota. http://www.mnhs.org/ library/tips/history_topics/72southdale.html

Figure 6: Gruen, Victor. The Heart of Our Cities; the Urban Crisis: Diagnosis and Cure. New York: Simon and Schuster, 1964, 272. http://s164. photobucket. com/user/c3m_2007/media/GruenCell.jpg.html

Figure 7: Digital Image created by author

Figure 8: Digital Image created by author

PART 2

Title page: "Levittown, Pennsylvania." Digital image. https://commons.wikimedia.org/wiki/ File:LevittownPA.jpg.

\section{CHAPTER 2.1}

Figure 1: Photograph of Lewis Mumford Digital image. http://www.nndb.com/ people/061/000087797/.

Figure 2: Stanziola, Phil. Mrs. Jane Jacobs, Chairman of the Comm. to save the West Village Holds up Documentary Evidence at Press Conference at Lions Head Restaurant at Hudson \& Charles Sts. December 5,1961 . Prints and Photographs Division, Library of Congress, New York City. http://www.loc.gov/ pictures/item/2008677538/.

Figure 3: Le Corbusier. Drawing. In The Radiant City. New York: Orion Press, 1933.

Figure 4: Smith, Claude. "Satire of Suburbia in the New Yorker Magazine 1958, Drawn by Claude Smith." Cartoon. The New Yorker, 1958.

\section{CHAPTER 2.2}

Figure 1: Lynch, Kevin. The Image of the City. Cambridge, Mass.: MIT Press, 1960, 47-48

Figure 2: Venturi, Robert, Denise Scott-Brown, and Steve Izenour. "Duck vs. Decorated Shed." 1977. https://blaservations.com/2012/11/30/theinexplicable-intertwinglement-of-architectural-theory/ robert-venturi-duck-vs-decorated-shed/.

Figure 3: Maule, Bradley. http://hiddencityphila. org/2013/04/at-drexel-iconic-isi-becomes-urbn/.

Figure 4: Progressive Architecture 48, no. 3 (March 1967): Cover.

Figure 5: [all] Digital image. Roger Sherman Architecture Urban Design. http://www.rsaud.com.

Figure 6: Levett, John. http://www.archdaily. com/150629/ad-classics-robin-hood-gardensalison-and-peter-smithson/50380d4b28baOd599b0 00b62-ad-classics-robin-hood-gardens-alison-andpeter-smithson-photo-by-john-levett-http-wwlickom- 
photos-joseph-beuys-hat

Figure 7:Divizia, Claudio. Saynatsalo Town Hall, by Alvar Aalto. Artifice Images, Saynatsalo, Finland.

http://www.greatbuildings.com/cgi-bin/gbi.cgi/ Saynatsalo_Town_Hall.html/cid_1165869844_4_23. html.

Figure 8: Davis, Howard. Exeter Library, by Louis I. Kahn. Exeter, New Hampshire. http://www. greatbuildings.com/cgi-bin/gbi.cgi/Exeter_Library. html/cid_1864941.html.

Figure 9: September 1, 2006. Wiki Commons. https://commons.wikimedia.org/wiki/File:Palace_of_ Assembly_Chandigarh_2006.jpg

Figure 10: Cook, Peter. Plug-In City. Archigram Archives. http://www.archdaily.com/399329/adclassics-the-plug-in-city-peter-cook-archigram/51d71 b74e8e44ed538000023-ad-classics-the-plug-in-citypeter-cook-archigram-image.

Figure 11: Rogers, Richard, and Renzo Piano. Elevation from the Competition Entry Illustrating the Concept of the Building as an Interactive Billboard. 1971. Rogers Stirk Harbour Partners. http://www. rsh-p.com/projects/gallery/?i=272\&p=99_0332_1_s0.

Figure 12: Photo of modernist tower on Dixie Road near Rathburn Road, Mississauga, Ontario. Personal photograph by author. March 13, 2016.

\section{CHAPTER 2.3}

Figure 1: Photo of The Heart of the City: Towards the Humanisation of Urban Life. London: Lund, Humphries, 1952, cover. http:// transculturalmodernism.org/article/158.

Figure 2: 1958. Panda Collection, Canadian Architectural Archives, University of Calgary., Toronto, Ontario. http://www.ryerson.ca/news/news/General_ Public/20150828-50-years-later-the-story-behind-cityhall.html.
Figure 3: Rudolph, Paul. 1973. In Megastructure: Urban Futures of the Recent Past. New York: Harper and Row, 1976, cover

Figure 4: Mellon Lectures, Canadian Centre for Architecture, Amsterdam. http://www.archdaily. com/151566/ad-classics-amsterdam-orphanage-aldovan-eyck/50380ed428ba0d599b000bcb-ad-classicsamsterdam-orphanage-aldo-van-eyck-photo.

Figure 5: Mellon Lectures, Canadian Centre for Architecture, Amsterdam. http://www.archdaily. com/151566/ad-classics-amsterdam-orphanage-aldovan-eyck/50380ed428ba0d599b000bcb-ad-classicsamsterdam-orphanage-aldo-van-eyck-photo.

Figure 6: Smithson, Alison and Peter.

Diagram of Cluster City. 1952. in Modernism without Rhetoric: Essays on the Work of Alison and Peter

Smithson. London: Academy Editions, 1997, 82

Figure 7: Digital Image by author

Figure 8: Personal photograph by author. December, 2015

Figure 9: Personal photograph by author. December, 2015.

\section{PART 3}

Title Page: Lateral Office. "Flatspace." Digital image. Lateral Office. 2004. http://lateraloffice.com/ FLATSPACE-2003-04

\section{CHAPTER 3.1}

Figure 1: April 1972. The Second, Widely Televised Demolition of a Pruitt-lgoe Building That Followed the March 16 Demolition. March 31, 1972. U.S.

Department of Housing and Urban Development, St. Louis, Missouri. https://en.wikipedia.org/wiki/PruittIgoe\#/media/File:Pruitt-igoe_collapse-series.jpg.

Figure 2: Krier, Léon. Drawing for Architecture. Cambridge, MA: MIT Press, 2009.
Figure 3: Duany Plater-Zyberg \& Company. "Updated Plan of Seaside, Florida." Drawing. Duany Plater-Zyberg \& Company. http://www.dpz.com/ Projects/7903\#

Figure 4: Gardner, Jack. Seaside, Florida. http://www. planetizen.com/node/67006.

Figure 5: Seaside, Florida. http://www.garrettrealty. com/communities/seaside.

Figure 6: Lilpandibear. March 26, 2010. Toronto, Ontario. https://www.flickr.com/photos/ lilpandibear/4465244771.

Figure 7: Urban Strategies Inc. Vaughan Metropolitan Centre Secondary Plan. Digital image. 2010. http://www.urbanstrategies.com/project/vaughanmetropolitan-centre-secondary-plan/.

Figure 8: Urban Strategies Inc. Tall Buildings Guidelines Prototype. Digital image. 2008. http:// www.urbanstrategies.com/project/toronto-tallbuildings/.

\section{CHAPTER 3.2}

Figure 1: Wright, Frank Lloyd. "Broadacre City." 1958. Architizer. http://architizer.com/blog/modernistutopian-architecture/.

Figure 2: Mishima, Satoru, Foreign Office Architects. Yokohama, Japan. http://www.archdaily. com/554132/ad-classics-yokohama-internationalpassenger-terminal-foreign-office-architectsfoa/542078e7c07a800de5000009-ad-classicsyokohama-international-passenger-terminal-foreignoffice-architects-foa-photo.

Figure 3: Lateral Office. "Flatspace." Digital image. Lateral Office. 2004. http://lateraloffice.com/ FLATSPACE-2003-04.

Figure 4: Robson Square, 800 Robson Street. 1986 City of Vancouver Archives, Vancouver, British Columbia. http://searcharchives.vancouver.ca/robson- 
square-800-robson-street-5.

Figure 5: @ Viñoly, Rafael, and OLIN Landscape Architects. Digital image. Dezeen. http://www. dezeen.com/2015/09/09/rafael-vinoly-reveals-planslargest-green-roof-in-world-silicon-valley-cupertinocalifornia/.

\section{CHAPTER 3.3}

Figure 1: City of Mississauga. in "Chapter 7:

Complete Communities." Mississauga Official Plan. August 11, 2015, 14

Figure 2: Seniors meeting for coffee, Rockwood Mall, Mississauga, Ontario. Personal photograph by author September 2015

Figure 3: City of Mississauga. in "Chapter 14: Community Nodes." Mississauga Official Plan. March $11,2016,1$

Figure 4: LTL Architects. "New Suburbanism." Digital image. http://Itlarchitects.com/new-suburbanism/.

\section{PART 4}

Title page: Rockwood Mall, Mississauga, Ontario. Personal photograph by author. March 13, 2016.

\section{CHAPTER 4.1}

Figure 1: Photos of existing architectural typologies, Rathwood Applewood. Personal photographs by author. 2015-2016.

Figure 2: Digital Image by author, information from City Of Mississauga Planning And Building Department. Census Results Ward 3 Profile. (City of Mississauga, June 2014)

Figure 3: Digital Image by author

\section{CHAPTER 4.2}

Figures 1-3: Digital Image by author
Figure 4: Digital Image by author, containing aerial photo by BingMaps.

Figures 5-12: Personal photographs by author. March $13,2016$.

Figure 13: Digital Image by author, containing aerial photo by BingMaps.

Figure : Digital Image by author, containing photo by

Scott Torrence Landscape Architect Inc. "Regent Park Phase 3 Development." Digital image. 2013. http://scotttorrance.ca/projects/regent-park-phase-3development/.

\section{PART 5}

Title Page: MVRDV. Markethal. 2015. Rotterdam, The Netherlands. https://www.mvrdv.nl/en/projects/ markethall.

\section{CHAPTER 5.1}

Figure 1: Van Den Broek \& Bakema Architects. Shopping Centre Lijnbaan Rotterdam. Sketch Collection, Het Nieuwe Instituut, Rotterdam, The Netherlands. http://www.metalocus.es/en/news/ dutch-pavilion-venice-biennale-spotlight-j-bakema.

Figure 2: Nijs, Jac. De. Metro Construction in Rotterdam Lijnbaan. March 30, 1967. Anefo Photo Collection, Netherlands National Archive, Rotterdam, Zuid-Holland. http://proxy.handle.net/10648/ ab142072-d0b4-102d-bcf8-003048976d84.

Figure 3: Cube Houses, Rotterdam, The Netherlands. Personal photograph by author. August 2014.

Figure 4: MVRDV. Ypenburg, The Netherlands. https://www.mvrdv.nl/projects/ypenburg.

Figure 5: De Kunstlinie Theater, and SANAA. Photo of OMA's Master Plan Model for Almere City Centre. http://www.archiweb.cz/news. php?action=show\&id=142\&type $=2$.
Figure 6: Almere, The Netherlands. http://www. architour.nl/almere-architektur-tour/.

\section{CHAPTER 5.2}

Figure 1: Mecanoo. Kruisplein Housing. 1985. Rotterdam, The Netherlands. http://www.mecanoo.nl/ Projects?project $=141$.

Figure 2: Kar, Michel Van De, and OMA. De Rotterdam. 2013. Rotterdam, The Netherlands. http://www.archdaily.com/451377/de-rotterdamoma/528fb02ae8e44e5368000224-de-rotterdamoma-photo.

\section{CHAPTER 5.3}

Figure 1: Digital Image by author

Figure 2: Mecanoo. Library Delft University of Technology. Delft, The Netherlands. http://www. mecanoo.nl/Projects/project/27/Library-DelftUniversity-of-Technology? $\mathrm{t}=0$.

Figure 3: Digital Image by author

Figure 4: Digital Image by author

Figure 5: MVRDV. Markethal. 2015. Rotterdam, The Netherlands. https://www.mvrdv.nl/en/projects/ markethall.

Figure 6: Digital Image by author

Figure 7: Digital Image by author

\section{PART 6}

All images created by author 


\section{BIBLIOGRAPHY}

Allen, Stan. "Mat Urbanism" Thick 2D." In CASE: Le Corbusier's Venice Hospital, edited by Hashim Sarkis. Munich: Prestel, 2002.

"Almere Masterplan." OMA. Accessed February 19, 2016. http://oma.eu/projects/almere-masterplan.

Archer, John. Architecture and Suburbia: From English Villa to American Dream House, 1690-2000. Minneapolis: University of Minnesota Press, 2005.

Archer, John, Paul J.P Sandul, and Katherine Solomonson. Making Suburbia: New Histories of Everyday America. Minneapolis: University of Minnesota Press, 2015.

"Architect Clarence Stein Assesses the Planning for Radburn, New Jersey." 1957. In The Suburb Reader, edited by Becky M. Nicolaides and Andrew Wiese, by Clarence Stein, 13-14. New York: Routledge, 2006.

Avermaete, Tom. Another Modern: The Post-war Architecture and Urbanism of Candilis-Josic-Woods. Rotterdam: NAi, 2005.

Bain, Alison L. Creative Margins: Cultural Production in Canadian Suburbs. Toronto: University of Toronto Press, 2013.

Banham, Reyner. Megastructure: Urban Futures of the Recent Past. New York: Harper and Row, 1976.

Banham, Reyner. "The New Brutalism." October 136 (2011): 19-28.

Beauregard, Robert A. When America Became Suburban. Minneapolis: University of Minnesota Press, 2006.

Betsky, Aaron, and Adam Eeuwens. False Flat: Why Dutch Design Is so Good, London: Phaidon, 2004.

Blauvelt, Andrew. Worlds Away: New Suburban Landscapes. Minneapolis: Walker Art Center, 2008.
Bruegmann, Robert. Sprawl: A Compact History. Chicago: University of Chicago Press, 2005.

City of Mississauga, Focus on Mississauga 2012: Atlas of the Downtown, Major Nodes and Community Nodes, City of Mississauga, 2012

City Of Mississauga Planning And Building Department. Census Results Ward 3 Profile. City of Mississauga, June 2014

City of Mississauga. Mississauga Official Plan. City of Mississauga, 2003. (updated October 14, 2015)

City of Mississauga. Mississauga Strategic Plan. City of Mississauga, 2009.

City of Mississauga. Our Future Mississauga: Growing Our Brand. City of Mississauga, 2014.

Cohen, Lizabeth. "From Town Center To Shopping Center: The Reconfiguration Of Community

Marketplaces In Postwar America." The American Historical Review 101, no. 4 (1996): 1050-081.

Accessed October 30, 2015. http://www.jstor.org/ stable/2169634

Congress for the New Urbanism. "Charter of the New Urbanism." 1996. In The Urban Design Reader, edited by Michael Larice and Elizabeth Macdonald. London: Routledge, 2007.

Cousins, Matthew. Design Quality in New Housing: Learning from the Netherlands. Abingdon, Oxon: Taylor \& Francis, 2009.

Cuff, Dana, and Roger Sherman. Fast-forward Urbanism: Rethinking Architecture's Engagement with the City. New York: Princeton Architectural Press, 2011

Deckker, Thomas. The Modern City Revisited. London: Spon, 2000.

" "Density in Communities, or the Most important factor in Building Urbanity" from Community Design and the Culture of Cities" 1990. In The Urban Design Reader, edited by Michael Larice and Elizabeth Macdonald, by Eduardo Lozano. London: Routledge, 2007.

Duany, Andres and Emily Talen, Landscape Urbanism and Its Discontents: Dissimulating the Sustainable City. Gabriola Island, BC: New Society Publishers, 2013.

Fishman, Robert. Bourgeois Utopias: The Rise and Fall of Suburbia. New York: Basic Books, 1987.

Foster, Hal. "IMAGE BUILDING." Artforum International. 43, no. 2 (10, 2004): 270-273,310311. http://ezproxy.lib.ryerson.ca/login?url=http:// search.proquest.com/docview/214352441?account id $=13631$.

Gallagher, Leigh. The End of the Suburbs: Where the American Dream Is Moving. New York: Penguin Group, 2013.

Gillham, Oliver. "“What Is Sprawl" from The Limitless City: A primer on the Urban Sprawl Debate." 2002. In The Urban Design Reader, edited by Michael Larice 287-306. London: Routledge, 2007.

Gruen, Victor. The Heart of Our Cities; the Urban Crisis: Diagnosis and Cure. New York: Simon and Schuster, 1964

Haddad, Elie, David Rifkind, and Peter L. Laurence, eds. Critical History of Contemporary Architecture: 1960-2010. Ashgate Publishing Group, 2014

Harris, Richard. Creeping Conformity: How Canada Became Suburban, 1900-1960. Toronto: University of Toronto Press, 2004.

Heuvel, Dirk Van Den. "Between Brutalists. The Banham Hypothesis and the Smithson Way of Life." The Journal of Architecture 20, no. 2 (2015): 293-308 doi:10.1080/13602365.2015.1027721.

Hicks, Kathleen A. "Part 4: 1951-2000" in Dixie: 
Orchards to Industry. Mississauga: Friends of the Mississauga Library System, 2006.

Hulsman, Bernard. Double Dutch: Architecture in the Netherlands since 1985. Rotterdam: Nai010 Publishers, 2014.

Ibelings, Hans. The Artificial Landscape:

Contemporary Architecture, Urbanism, and Landscape Architecture in the Netherlands. Rotterdam: NA Publishers, 2000.

Ingersoll, Richard. Sprawltown: Looking for the City on Its Edges. New York: Princeton Architectural Press, 2006

Jacobs, Jane. The Death and Life of Great American Cities. New York: Vintage Books, 1992.

Jencks, Charles. The Language of Post-modern Architecture. New York: Rizzoli, 1977.

Kapelos, George, and Christopher Armstrong. Competing Modernisms: Toronto's New City Hall and Square. Toronto: Dalhousie Architectural Press, 2015.

Kolb, David. Sprawling Places. Athens: University of Georgia Press, 2008.

Koolhaas, Rem. Delirious New York: A Retroactive Manifesto for Manhattan. London, 1978.

Koolhaas, Rem, Bruce Mau, and Jennifer Sigler. "Bigness." in S, M, L, XL. Rotterdam: 010 Publ., 1995.

Krier, Léon. The Architecture of Community. Washington, DC: Island Press, 2009.

Kruse, Kevin Michael, and Thomas J. Sugrue, eds. The New Suburban History. Chicago: University of Chicago Press, 2006.

Kunstler, James Howard. The Geography of Nowhere: The Rise and Decline of America's Man-made Landscape. New York: Simon \& Schuster, 1993.
Kusadali, Meliz. "Rob Krier: Urban Space (1979)." Architecture Urbanism A Blog From The Ma Architecture Urbanism Course At The Manchester School Of Architecture (blog), March 25, 2011. Accessed February 12, 2016. http:// architectureandurbanism.blogspot.ca/2011/03/robkrier-urban-space-1979.html.

Lewis, Paul, Marc Tsurumaki, and David J. Lewis. Lewis. Tsurumaki. Lewis: Opportunistic Architecture. Chicago: Graham Foundation for Advanced Studies in the Fine Arts, 2008.

Livingstone, Marco. Pop Art: A Continuing History. London: Thames and Hudson, 1990.

Lootsma, Bart. Superdutch: New Architecture in the Netherlands. New York: Princeton Architectural Press, 2000.

Lukez, Paul. Suburban Transformations. New York: Princeton Architectural Press, 2007.

Lynch, Kevin. The Image of the City. Cambridge, Mass.: MIT Press, 1960.

Martin, Michael David. "Returning to Radburn." Landscape Journal 20, no. 2 (2001): 156-75. doi:10.3368/lj.20.2.156.

"Masterplan Almere-Centrum, Almere-Stad." Architectureguide.nl. Accessed February 19, 2016. http://www.architectureguide.nl/project/list_projects_ of_city/cit_id/12/prj_id/1553.

Moore, Charles. Daniel H. Burnham, Architect, Planner of Cities, Volume 2. Boston, Houghton Mifflin, 1921, 147

Mumford, Eric Paul. The CIAM Discourse on

Urbanism, 1928-1960. Cambridge, Mass.: MIT Press, 2000.

Mumford, Lewis "Suburbia and Beyond" in The City in History: Its Origins, Its Transformations, and Its Prospects. New York: Harcourt, Brace \& World, 1961.
Mumford, Lewis. "The Garden City Idea and Modern Planning" From the 1946 Introduction to Garden Cities of To-Morrow (1902)." In The Urban Design Reader, edited by Michael Larice and Elizabeth Macdonald. London: Routledge, 2007.

Nicolaides, Becky and Andrew Wiese, The Suburb Reader, New York: Routledge, 2006.

Pedret, Annie. Team 10: An Archival History. London: Routledge Taylor \& Francis Group, 2013.

Perry, Clarence. " "The Neighbourhood Unit" from The Regional Plan of New York and Its Environs." 1929. In The Urban Design Reader, edited by Michael Larice and Elizabeth Macdonald. London: Routledge, 2007.

Poulin, Richard. Graphic Design Architecture, a 20th Century History: A Guide to Type, Image, Symbol, and Visual Storytelling in the Modern World. Beverly, MA: Rockport Publishers, 2012

"Poundbury." The Prince of Wales and the Duchess of Cornwall. Accessed February 12, 2016. http://www. princeofwales.gov.uk/features/poundbury.

"Rafael Viñoly Plans World's Largest Green Roof for Silicon Valley." Dezeen. September 09, 2015. Accessed February 13, 2016. http://www.dezeen. com/2015/09/09/rafael-vinoly-reveals-planslargest-green-roof-in-world-silicon-valley-cupertinocalifornia/.

Reynolds, Malvina, writer. Little Boxes. Malvina Reynolds. Schroder Music Company, 1962

Rossi, Aldo, and Peter Eisenman. "Editor's Introduction." In The Architecture of the City. Cambridge, Mass.: MIT Press, 1982.

Sadler, Simon. Archigram: Architecture without Architecture. Cambridge, MA: MIT Press, 2005.

Sabini, Maurizio. "Pragmatic Modernism: The Dutch Laboratory on Architecture , Landscape and the City," in Getting Real: Design Ethos Now: Abstracts. edited by Renee Cheng and Patrick J. Tripeny. Washington, 
DC: Association of Collegiate Schools of Architecture, 2006.

Sadler, Simon. Archigram: Architecture without Architects. Cambridge, MA: MIT Press, 2005.

Smiley, David. Sprawl and Public Space Redressing the Mall. Washington, D.C.: National Endowment for the Arts, 2002.

Urbaniak, Tom. Her Worship: Hazel McCallion and the Development of Mississauga. Toronto: University of Toronto Press, 2009.

Van den Heuvel, Dirk. 2015. "Between Brutalists. The Banham Hypothesis and the Smithson Way of Life".

The Journal of Architecture 20 (2): 293-308.

Venturi, Robert, and Denise Scott-Brown. Learning from Las Vegas: The Forgotten Symbolism of Architectural Form. Rev. ed. Cambridge, Mass.: MIT Press, 1977.

Waldheim, Charles. The Landscape Urbanism Reader. New York: Princeton Architectural Press, 2006.

Welter, Volker M." From Locus Genii to the Heart of the City: Embracing the Spirit of the City." In Modernism and the Spirit of the City, edited by lain Boyd Whyte, London: Routledge, Taylor \& Francis Group, 2003. 


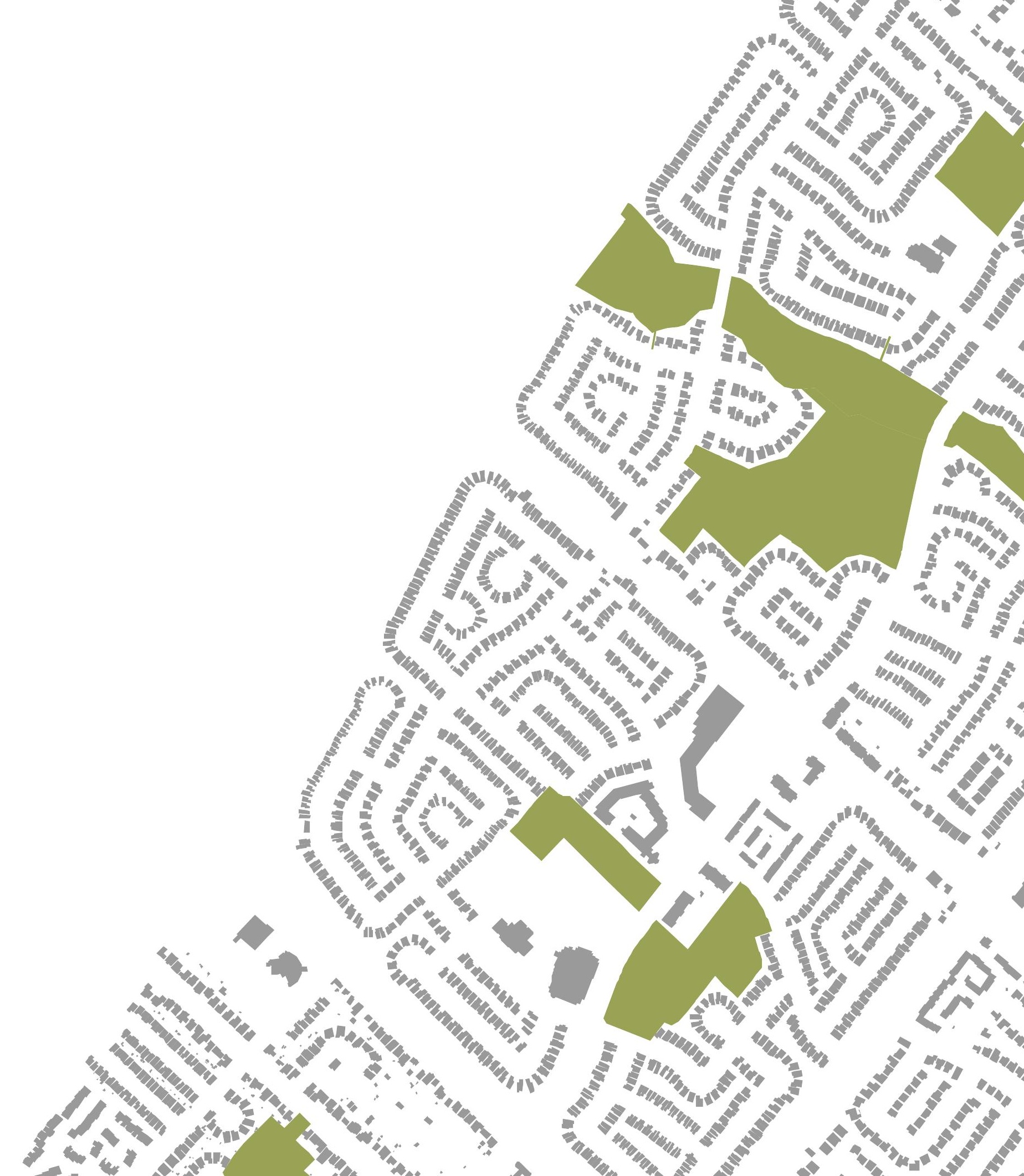

